Fernando César Nimer Moreira da Silva

\title{
INCENTIVOS À DECISÃO DE RECUPERAÇÃO DA EMPRESA EM CRISE: ANÁLISE À LUZ DA TEORIA DOS JOGOS
}

\author{
Dissertação de Mestrado \\ Orientação: Professora Associada RACHEL SZTAJN
}

Faculdade de Direito da Universidade de São Paulo

São Paulo 
Banca Examinadora: 


\section{ÍNDICE}

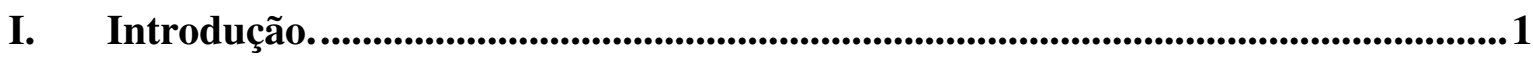

I.1. Apresentação e justificativa para escolha do tema. ............................................. 1

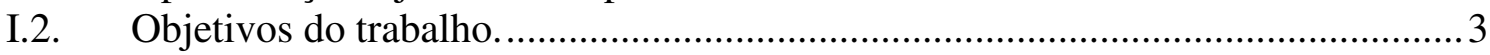

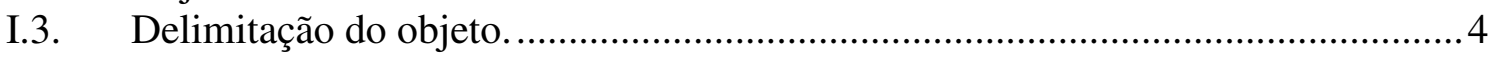

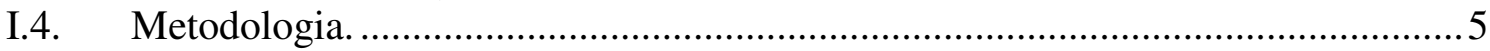

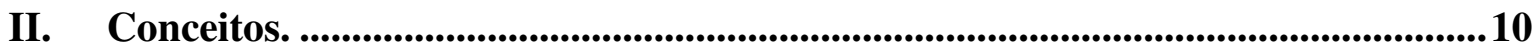

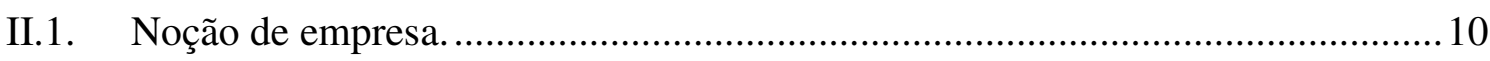

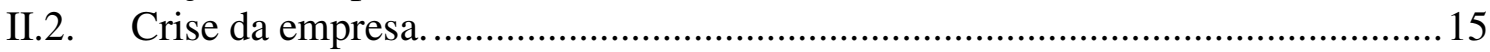

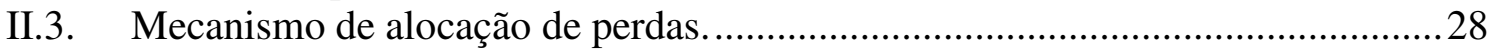

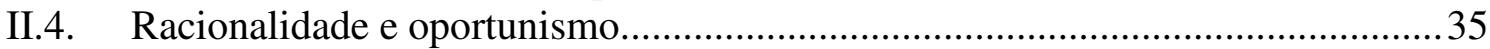

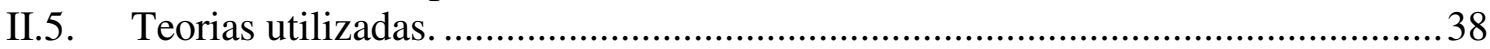

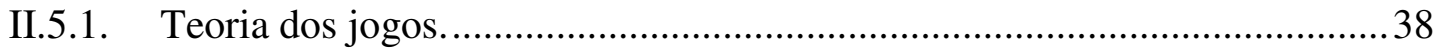

II.5.2. Teoria do desenho de mecanismos. .......................................................... 44

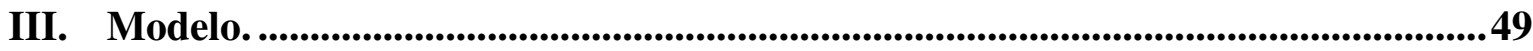

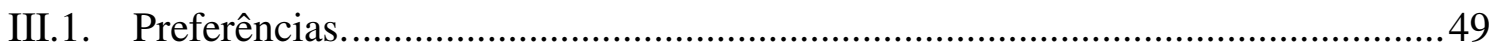

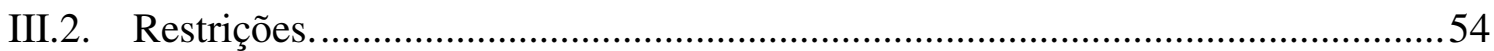

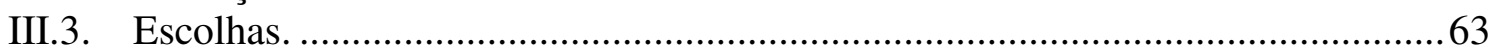

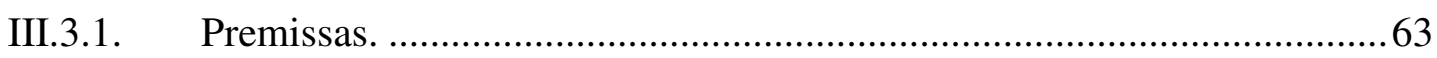

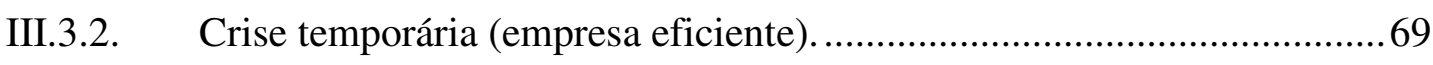

III.3.3. Crise estrutural (empresa ineficiente) ................................................... 86

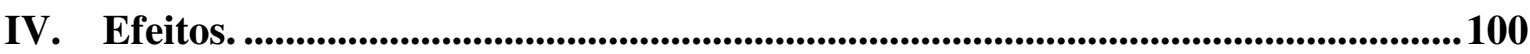

IV.1. Espécie de empresa submetida a concurso de credores...................................... 100

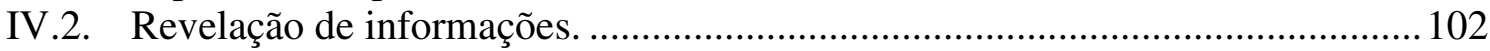

IV.2.1. Incentivos para sonegação de informação. ........................................... 102

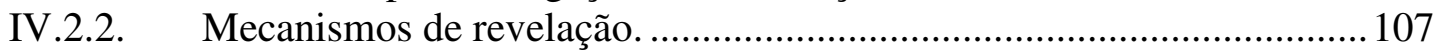

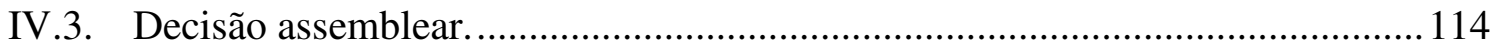

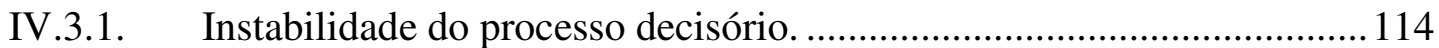

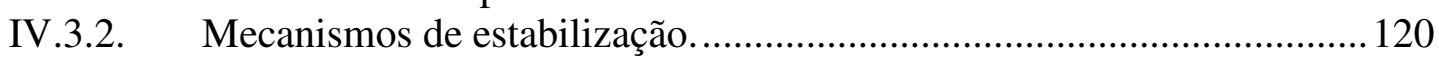

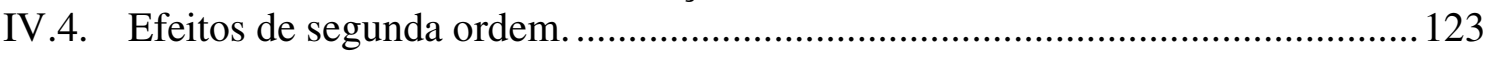

V. Apêndice: formulação matemática do modelo. .....................................................128

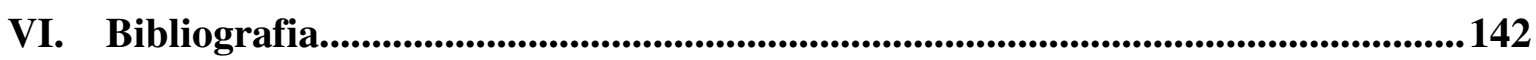

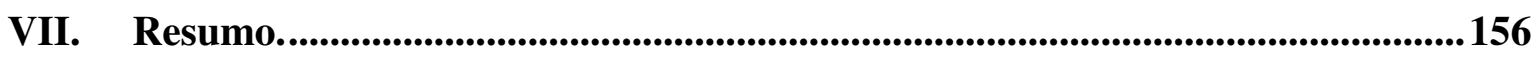

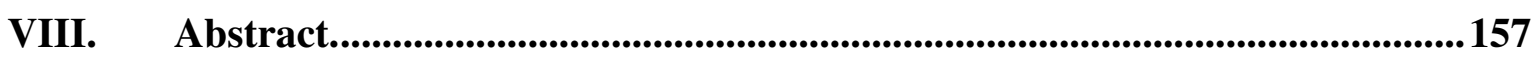


"O que, exatamente, é o pensamento? Quando, na percepção das impressões sensoriais, emergem figuras da memória, isto ainda não é 'pensar'. E quando esses quadros formam seqüências, cada membro criando o outro, isto também ainda não é 'pensar'. Porém, quando uma certa figura aparece em várias seqüências, nesse caso - precisamente devido a essa recorrência - torna-se um elemento de organização para tais sequiências, no sentido de unir seqüências que por si mesmas não se relacionam entre si. Esse elemento vem a ser um instrumento, um conceito. Creio que a transição da livre associação ou 'sonho' para o pensamento caracteriza-se pelo papel mais ou menos importante representado pelo conceito. Não é de modo algum necessário que o conceito esteja ligado a um signo que possa ser reconhecido e reproduzido pelos sentidos (palavra), mas, quando isto se dá, o pensamento torna-se, por esse meio, capaz de ser comunicado. Com que direito - perguntará o leitor - o homem opera com tal descuido e de forma tão elementar com idéias, nesse reino tão problemático, sem ao menos tentar provar alguma coisa? Minha defesa: todos os nossos pensamentos têm a natureza do jogo livre dos conceitos; a justificativa desse jogo está no grau de compreensão das sensações que podemos alcançar com a sua ajuda. $O$ conceito de 'verdade' não pode ainda ser aplicado a essa estrutura; na minha opinião, esse conceito só é aplicável quando temos à mão um acordo (convenção) que abrange os elementos e as regras do jogo".

EINSTEIN, Albert, Notas autobiográficas, Ed. Nova Fronteira, 2a. Ed., 1982, pp.17-18. 


\section{Introdução.}

\section{I.1. Apresentação e justificativa para escolha do tema.}

O texto em epígrafe resume o principal objetivo do trabalho e, ao mesmo tempo, justifica a estrutura "descuidada" segundo a qual os pensamentos foram expostos e organizados. O presente estudo procura identificar os conceitos-chave presentes no procedimento de insolvência empresarial, com o objetivo de aumentar o grau de compreensão a respeito das decisões estratégicas tomadas por devedores e credores para solucionar a crise da empresa. Reconhecendo que o conceito de verdade é relativo, recorre-se ao uso de premissas que definem as regras do jogo. Utiliza-se a matemática, cuja linguagem rigorosa permite construir um modelo ideal que pode ser confrontado com as regras previstas na lei brasileira (LREF) ${ }^{1}$.

Uma lei concursal deve ser instituto ${ }^{2}$ apto a criar incentivos para induzir o comportamento de devedores e credores, maximizando o bem-estar geral $^{3}$. Deve funcionar como mecanismo que realiza a alocação de perdas, evitáveis ou não, a devedores e credores ${ }^{4}$.

Empresa é negócio de natureza econômica e a crise da empresa deve ser tratada segundo essa perspectiva. A recuperação da empresa em crise é uma "proposta de investimento" oferecida aos credores. Para avaliar a viabilidade de tal investimento e compará-lo com as opções existentes no mercado, os credores devem receber informação adequada e o processo de decisão que aprova ou rejeita o investimento coletivo (assembléia de credores) deve transcorrer livre de oportunismos.

\footnotetext{
${ }^{1}$ Lei n. 11.101/2005 - lei de recuperação de empresas e falência, doravante denominada LREF.

${ }^{2}$ Instituições são regras do jogo na sociedade, restrições impostas aos indivíduos para que possam interagir, estruturando incentivos para as trocas. Elas reduzem a incerteza, pois criam estruturas para guiar a interação humana, definindo e limitando as escolhas individuais. As instituições podem ser formais ou informais, contendo permissões ou proibições de conduta. (NORTH, Douglass C. Institutions, institutional change and economic performance. New York: Cambridge University Press, 2002, pp. 3-4)

${ }^{3}$ De acordo com Nicholas Mercuro e Steven Medema, são as relações legais que governam a sociedade e afetam o resultado econômico, pois alteram a estrutura de incentivos. (MERCURO, Nicholas; MEDEMA, Steven G. Economics and the Law. Princeton: Princeton University Press, 1997, pp. 21-24)

${ }^{4}$ STANGHELLINI, Lorenzo. Crisi di impresa fra diritto ed economia - le procedure di insolvenza. Bologna: Il Mulino, 2007, pp. 30-33; 105-106; 113-114.
} 
Os principais objetivos da lei concursal devem ser: (i) evitar perdas, maximizando o valor da empresa; (ii) revelar informações que permitam reduzir as assimetrias de informação existentes; (iii) criar condições para alcançar a falência da empresa ineficiente ou a recuperação da empresa eficiente.

A lei, tradicionalmente, tem sido objeto de estudo de juristas, mas também interessa a economistas, uma vez que as decisões e comportamentos das partes envolvidas no concurso podem ser estudados sob a ótica econômica.

Do ponto de vista da economia, a lei deve ser capaz de minimizar os custos sociais da insolvência. Do ponto de vista jurídico, a lei deve ser capaz de uniformizar o tratamento dado a casos similares, alcançando justiça e eqüidade nas decisões. Sob a ótica combinada de direito e economia, importa enfocar o problema dos incentivos, analisando se a lei é capaz de induzir os agentes a tomar decisões que maximizem o bem-estar geral.

A crise da empresa torna explícitos os interesses em conflito e as distintas visões sobre as causas. Os interesses influenciam a escolha de estratégias. O retorno esperado com tais escolhas depende dos direitos envolvidos, custos de monitoração e exercício de direitos, informação disponível, condições econômico-financeiras da empresa e do mercado, passagem do tempo e incentivos existentes. Uma estrutura inadequada de incentivos legais pode levar a soluções indesejadas, isto é, a liquidação da empresa eficiente ou a recuperação da ineficiente.

A antiga disciplina de insolvência empresarial (Decreto-Lei n. 7.661/45) previa as hipóteses de falência e de concordata. A nova lei suprimiu a concordata, modificou a disciplina falimentar e introduziu a possibilidade de recuperação da empresa, modificando os incentivos e as possibilidades de escolha dos agentes, outorgando aos credores a decisão final a respeito da recuperação da empresa ${ }^{5}$.

\footnotetext{
${ }^{5}$ Mauro Penteado indica que as soluções previstas na LREF não são tão inovadoras como pode parecer à primeira vista. O autor aponta que o Código Comercial de 1850 adotava duas soluções, a concordata e a moratória, esta similar à concordata preventiva do Decreto-Lei n. 7.661/45, com a diferença que a concordata era dependente de aprovação dos credores. É solução semelhante à adotada pela LREF para a recuperação judicial (arts. 55, 56, 58) e para a recuperação extrajudicial (art. 161). O autor anota ainda que os credores
} 
A metodologia de direito e economia utilizada em nosso trabalho procura avaliar se os incentivos legais são capazes de resolver o problema da insolvência, se comparados à solução ideal indicada por um modelo matemático desenvolvido para a mesma finalidade.

\section{I.2. Objetivos do trabalho.}

O estudo tem por objetivo propor modelo teórico de análise dos principais incentivos legais e econômicos que induzem a decisão referente ao destino da empresa. O modelo é comparado às soluções propostas pela LREF, com o objetivo de identificar se a lei é capaz de maximizar o bem-estar social.

O trabalho propõe-se a cumprir três tarefas.

A primeira consiste na apresentação dos conceitos utilizados, que são predefinidos a fim de evitar divergências de interpretação (capítulo II).

A segunda propõe-se a elaborar modelo teórico para entender o comportamento estratégico dos agentes que optam entre a recuperação, a falência ou a negociação privada de dívidas ${ }^{6}$. O modelo é comparado à lei, apontando as possibilidades de escolha e demonstrando o desalinhamento entre a decisão eficiente, sugerida pelo modelo, e as escolhas feitas pelos agentes, com base em incentivos legais (capítulo III).

A terceira tarefa resume-se a identificar os principais efeitos do desalinhamento e sugerir correções para os principais problemas (capítulo IV).

O apêndice (capítulo V) descreve a formulação matemática do modelo proposto.

participavam de reuniões e que as deliberações eram tomadas por maioria, vinculando os ausentes (arts. 844 a 847 do Código Comercial). (PENTEADO, Mauro R. Comentários. In SOUZA JR, Francisco Satiro de; PITOMBO, Antonio Sérgio A de Moraes (coord.). Comentários à lei de recuperação de empresas e falência. São Paulo: Revista dos Tribunais, 2005, pp. 62-63).

${ }^{6} \mathrm{O}$ termo utilizado pela doutrina estrangeira para a reestruturação de dívidas é workout. 


\section{I.3. Delimitação do objeto.}

Nosso estudo enfoca a sociedade empresária, anônima ou limitada, excluindo as instituições financeiras e equiparadas, bem como pequenas e médias empresas?

Hipóteses englobando situações de fusão, incorporação, cisão, transformação de sociedades, e grupos societários, são desconsideradas por este trabalho. Exclui-se também a análise de mercados regulados.

Também não é objeto de estudo o Decreto-Lei n. 7.661/45 (antiga Lei de Falências), exceto quando a comparação com a nova lei é necessária ao elucidar os novos institutos jurídicos. Da mesma forma, a legislação aplicável a situações especiais: regime de intervenção e liquidação extrajudicial de instituições financeiras (Lei n. 6.024/74 e Lei n. 9.447/97); regime de administração especial temporária de instituições financeiras (Decreto-Lei n. 2.321/87); insolvência civil de sociedades não empresárias (Código de Processo Civil, art. 748 e seguintes); sociedades cooperativas (Lei n. 5.764/71); consórcios (Lei 5.768/71); sociedades seguradoras (Decreto-Lei 73/66); entidades de previdência complementar (Lei Complementar n. 109/01); operadoras de plano de saúde (Lei n. 9.656/98).

Não empregamos método de direito comparado. As referências ao direito estrangeiro servem apenas para melhor compreensão da lei brasileira.

\footnotetext{
${ }^{7}$ Carlos Zanini entende não haver tratamento adequado às pequenas e médias empresas na lei brasileira. Segundo ele, o plano especial (LREF, arts. 70 a 72) guarda semelhanças com a concordata do Decreto-Lei $7.661 / 45$, não abrange todos os créditos e traz normas mais brandas que as previstas no procedimento de execução por quantia certa contra devedor insolvente (Código de Processo Civil, art. 748 e seguintes). O plano especial abrange apenas créditos quirografários (art. 71, I da LREF), enquanto o devedor civil insolvente responde com todos os bens por todas as dívidas (art. 751 do Código de Processo Civil). (ZANINI, Carlos K. Comentários. In SOUZA JR, Francisco Satiro de; PITOMBO, Antonio Sérgio A de Moraes (coord.). Comentários à lei de recuperação de empresas e falência. São Paulo: Revista dos Tribunais, 2005, pp. 314-323). Mauro Penteado entende que a lei parece ser compatível apenas com as necessidades das grandes empresas, sendo pouco útil para auxiliar as pequenas e médias, dificultando a uniformização de tratamento pretendida. (PENTEADO, Mauro R. Comentários. In SOUZA JR, Francisco Satiro de; PITOMBO, Antonio Sérgio A de Moraes (coord.). Comentários à lei de recuperação de empresas e falência. São Paulo: Revista dos Tribunais, 2005, pp. 56-57). Jeremy Berkowitz e Michele White sugerem que, freqüentemente, os débitos de pequenas empresas confundem-se com dívidas particulares dos sócios, tornando difícil a análise do tema sob o prisma do direito empresarial. (BERKOWITZ, Jeremy; WHITE, Michelle J. Bankruptcy and small firms' access to credit. John M. Olin Center for Law \& Economics University of Michigan Law School, Paper n. 00-005, June 2000. Disponível em: $<$ http://papers.ssrn.com/paper.taf?abstract_id=233248>. Acesso em 23.jan.2006, pp. 1-3).
} 
Não consideramos dados estatísticos sobre empresas brasileiras em crise, pois não é possível produzir análises conclusivas com as informações disponíveis. Os dados estatísticos anteriores à vigência da nova lei são inapropriados para tal tarefa, e os estudos estrangeiros servem apenas para facilitar a compreensão dos temas tratados.

Não estudamos casos concretos. Os casos paradigmáticos e as referências jurisprudenciais são utilizados apenas para reforço de argumentação.

Não modelamos todas as soluções possíveis nem sugerimos correções para todos os problemas existentes. O modelo proposto aponta apenas as alternativas estratégicas para os principais problemas, limitadas pelas premissas estabelecidas. $\mathrm{O}$ modelo concentra-se nas atividades de propositura do plano de recuperação, pelo devedor, e na assembléia de credores que decide a solução para a crise. Enfatizamos a análise de dois problemas essenciais para a tomada de decisão: a revelação de informações e a votação em assembléias de credores.

Eliminamos outros temas do escopo, com o objetivo de reduzir a complexidade da análise. São eles: (i) habilitação de credores, verificação de créditos e formação do quadro-geral de credores; (ii) escolha do administrador judicial, auxiliares do juízo, comitê de credores e outros agentes; (iii) processamento do pedido de recuperação ou falência; (iv) meios de recuperação judicial; (v) classificação dos créditos na falência; (vi) pedido de restituição de bens; (vii) arrecadação de bens do falido; (viii) efeitos da decretação da falência e da recuperação sobre as obrigações do falido; (ix) ineficácia e revogação de atos praticados pelo falido; (x) realização do ativo e pagamento do passivo; (xi) extinção das obrigações e reabilitação do falido; (xii) disposições penais.

\section{I.4. Metodologia.}

Empregamos métodos de análise econômica do direito com o propósito de entender os incentivos, o comportamento e as decisões tomadas pelos agentes ${ }^{8}$.

\footnotetext{
8 “O núcleo do programa da política e do direito como ciência tem, já descrito em outro lugar, como componente fundamental três teses ontológicas. A primeira afirma que a única entidade real é o indivíduo
} 
Construímos um modelo lógico-formal dinâmico que incorpora elementos econômicos e jurídicos. Esse tipo de modelo é construção abstrata usada para explicar determinado aspecto da realidade, captar sua essência, relações internas, evolução e fatores que determinam as mudanças. Trata-se de um modelo dinâmico, pois os valores das variáveis alteram-se ao longo do tempo?

Todo modelo tem a finalidade de identificar situações predeterminadas, sugerindo alternativas e soluções a partir de um conjunto de premissas. Nosso modelo é construído para auxiliar os tomadores de decisão - juiz, administrador judicial, advogados, partes - a entender e avaliar os incentivos existentes, propondo escolhas estratégicas para maximizar os resultados individuais e o bem-estar geral. Trata-se de modelo simplificado cuja formulação matemática não foi detalhada, pois atribuímos maior prioridade à análise interpretativa das hipóteses, e não à prova matemática das proposições.

Por um lado, um modelo é forma de simplificação da realidade, pois reflete a opção de privilegiar determinados aspectos de um problema em detrimento de outros. Por outro lado, um modelo permite analisar novas relações entre problemas. $\mathrm{O}$ uso de categorizações e regras para adequar a conduta humana é usual em estudos jurídicos ${ }^{10}$, mas a construção de modelos lógico-formais não tem sido utilizada com o mesmo entusiasmo.

como racional e auto-interessado. Sua racionalidade é aquela do modelo de escolha racional. Essa tese reflete de maneira mais elaborada a afirmação do individualismo ontológico e metodológico. A heurística do programa contém o uso de modelos, que descrevem os aspectos relevantes dos assuntos a serem abordados, o método de agregação, as hipóteses auxiliares, as técnicas de cálculos, critérios e medidas de escolha social, em particular, o critério de custo e benefício, e, finalmente, como seu problema fundamental, o estabelecimento das condições para a coordenação e convivência social aqui representado pelo problema das condições da emergência e da estabilidade da cooperação entre indivíduos interagentes. A combinação destes instrumentos metodológicos, como os modelos, modelo de escolha racional e o uso dos critérios e medidas de bem estar, no caso, do critério de custo e benefício, utilizados para abordar os temas mencionados, em particular, o tema da teoria do Estado, poder-se-ia ser denominada modernamente de análise econômica do direito". (CHIAPPIN, J. R. N.; LEISTER, Ana C. Reconstrução racional do programa de pesquisa da política, e do direito, como ciência e da abordagem do problema da emergência e estabilidade da cooperação entre indivíduos interagentes. A construção do Estado de Direito e a heurística do contratualismo. Não publicado, 2007, p.3)

${ }^{9}$ SANDRONI, Paulo. Dicionário de Economia. $3^{\text {a }}$ ed., São Paulo: Best Seller, 1994, pp. 227-229.

${ }^{10}$ Exemplos de uso de padrões no direito: homem ativo e probo (Código Civil, art. 1011; LSA, arts. 68 e 153), boa-fé e bons costumes (Código Civil, arts. 113, 122, 128, 187, 422, 1049, 1149; LSA, arts. 2º 97, 107 , $135,151,159,183,201)$. 
Guido Calabresi e Douglas Melamed apontam que, às vezes, os modelos podem não fornecer a visão completa do problema analisado. Os autores explicam que os pesquisadores do direito tendem a evitar a construção de modelos, preferindo proceder de forma ad hoc, enfocando estudos de casos e observando as categorias que surgem. Calabresi e Melamed criticam essa abordagem, apontando que tal conduta enfoca apenas um aspecto do problema, negligenciando correlações entre elementos que podem ser percebidas com o uso de modelos, uma vez que estes não geram categorias ${ }^{11}$.

Nosso modelo utiliza a estrutura conceitual da teoria da escolha racional, que explica como os agentes realizam escolhas a partir de preferências, limitados pelas restrições existentes. A teoria permite extrair conclusões a partir de um pequeno conjunto de regras e premissas, mas não impede que os agentes incorram em erros nem considera o contexto social e cultural das decisões ${ }^{12}$. A teoria pressupõe que os agentes são racionais, auto-interessados e adotam comportamentos independentes. Esta última característica simplifica demais o problema, não servindo aos propósitos de nossa análise. Por isso, o modelo utiliza a teoria dos jogos ${ }^{13}$, pois o agente realiza escolhas que dependem das decisões tomadas pelos demais agentes.

Formulamos hipóteses teóricas sobre os incentivos legais que afetam as opções modeladas: reestruturação privada de dívidas, falência ou recuperação da empresa. $\mathrm{O}$ modelo elabora jogos não-cooperativos ${ }^{14,15}$ e os compara com as soluções legais,

${ }^{11}$ CALABRESI, Guido; MELAMED, Douglas A. Property rules, liability rules, and inalienability: one view of the cathedral. Harvard Law Review, V. 85, n. 6, April 1972, pp. 1127-1128.

${ }^{12}$ FIANI, Ronaldo. Teoria dos jogos. $2^{\text {a }}$ ed., São Paulo: Campus, 2006, pp. 23-34. CHIAPPIN, J. R. N.; LEISTER, Ana C. Reconstrução racional do programa de pesquisa da política, e do direito, como ciência e da abordagem do problema da emergência e estabilidade da cooperação entre indivíduos interagentes. A construção do Estado de Direito e o núcleo teórico do contratualismo. Não publicado, 2007; CHIAPPIN, J. R. N.; LEISTER, Ana C. Reconstrução racional do programa de pesquisa da política, e do direito, como ciência e da abordagem do problema da emergência e estabilidade da cooperação entre indivíduos interagentes. A construção do Estado de Direito e a heurística do contratualismo. Não publicado, 2007.

${ }^{13}$ Seção II.5.1.

${ }^{14}$ BAROSSI FILHO, Milton. As assembléias de credores e plano de recuperação de empresas: uma visão da teoria dos jogos. Revista de Direito Mercantil, Industrial, Econômico e Financeiro, Ano XLIV, n. 137, pp. 233-238, jan./mar. 2005; WHITE, Michelle J. The corporate bankruptcy decision. In: POSNER, Richard; PARISI, Francesco, Law and economics. Cheltenham, UK: Lyme, US: Edward Elgar Publishing, Volume III, pp. 293-371, 1997; WEBB, David C. The importance of incomplete information in explaining the existence of costly bankruptcy. Economica, New Series, Vol. 54, n. 215, pp. 279-288, Aug. 1987.

${ }^{15}$ Não foram analisados aspectos cognitivos do comportamento dos agentes. Ver, a esse respeito: PARISI, Francesco; SMITH, Vernon. The law and economics of irrational behavior: an introduction. George Mason 
objetivando encontrar diferenças entre as soluções propostas pelo modelo e as normas jurídicas, isto é, entre o efetivo comportamento dos agentes e o presumido pela lei.

A modelagem é feita em jogos na forma matricial e extensiva. Não são mapeadas todas as estratégias possíveis, apenas as mais prováveis. O modelo procura identificar soluções heurísticas, isto é, possíveis de serem alcançadas ${ }^{16}$.

O trabalho baseia-se no uso de modelos mentais, estruturas lógicas criadas para produzir hipóteses e conclusões, com o objetivo de fazer previsões sobre o comportamento dos agentes. Quando a previsão é confirmada, o modelo transforma-se em crença, caso contrário, é modificado ou descartado. O uso de modelos mentais permite alcançar a independência entre as hipóteses formuladas e a existência prévia de dados empíricos. A aceitação ou rejeição posterior do modelo, entretanto, deve ser feita com base na análise de dados ${ }^{17}$.

As hipóteses de nosso modelo são formuladas com base em probabilidades predefinidas, pois não há dados empíricos para testar as suposições. Esse tipo de probabilidade, aplicável antes da coleta de amostras, é subjetiva, baseada em juízos pessoais ou informações históricas, podendo ser validada por dados coletados posteriormente ${ }^{18}$. A coleta de dados, entretanto, não é escopo de nosso estudo.

Nosso estudo parte de modelo teórico construído sobre premissas independentes,

University Law and Economics Research Paper Series. Disponível em: <http://ssrn.com/abstract_id=586649>. Acesso em: 15.abr.2006; CAMERER, Colin F.; HO, Teck-Hua; CHONG, Juin-Kuan. A cognitive hierarchy theory of one-shot games and experimental analysis. September 8, 2003. Disponível em <http://www.ssrn.com>. Acesso em: 03.dez.2006.

${ }^{16}$ Heurística é utilizada em dois sentidos possíveis: como procedimento para atingir o resultado desejado; e como solução possível de ser alcançada. (GIGERENZER, Gerd. Heuristics. In GIGERENZER, Gerd; ENGEL, Christoph (coord.). Heuristics and the law, Cambridge: The MIT Press, 2004, p. 17)

${ }^{17}$ MANTZAVINOS, C.; NORTH, D. C.; SHARIQ, S. Learning, Institutions and Economic Performance. Preprints of the Max Planck Institute for Research on Collective Goods, Bonn, 2003/13. Disponível em http://ssrn.com/abstract=510902. Acesso em: 23.jan.2006, pp. 4-5. Ver também: CHIAPPIN, J. R. N.; LEISTER, Ana C. Experimento mental I: a concepção contratualista clássica, o modelo da tragédia dos comuns e as condições de emergência e estabilidade da cooperação - Hobbes. Maio 2007. Disponível em: <http://repositories.cdlib.org/bple/alacde/052307-1>. Acesso em: 01.jun.2007; CHIAPPIN, J. R. N.; LEISTER, Ana C. Experimento mental II: a concepção contratualista clássica, o modelo da tragédia dos comuns e as condições de emergência e estabilidade da cooperação - Locke, Rousseau e Kant. Maio 2007. Disponível em: <http://repositories.cdlib.org/bple/alacde/060507-1>. Acesso em: 01.jun.2007)

${ }^{18}$ KASMIER, Leonard J. Estatística aplicada à Economia e Administração. São Paulo: Makron Books, 1982, p. 259. 
cujas soluções são comparadas às previsões legais usando o conceito de "compatibilidade de incentivos", previsto pela teoria de desenho de mecanismos ${ }^{19}$. Há compatibilidade quando o mecanismo incentiva o agente a revelar voluntariamente a informação privada.

Sugerimos correções para os efeitos negativos produzidos pelas normas jurídicas, a partir da aplicação do princípio da revelação e da teoria da implementação. O princípio da revelação indica a melhor solução que incentiva os agentes a indicarem suas preferências. A teoria da implementação traça as linhas mestras que permitem tornar efetivos os mecanismos desenhados para atingir tal finalidade.

${ }^{19}$ Seção II.5.2. 


\section{Conceitos.}

\section{II.1. Noção de empresa.}

Empresa é termo equívoco. A LREF não a define ${ }^{20}$, dificultando o entendimento sobre a crise. Nosso estudo não pretende elaborar a disciplina jurídica da empresa, mas apenas adotar definição útil aos propósitos da análise.

Uma definição jurídica de empresa pode ser derivada da interpretação dos artigos 966 e 1142 do Código $\mathrm{Civil}^{21}$, que a conceitua como atividade econômica que organiza a produção e comercialização de produtos e serviços, podendo utilizar-se de um complexo de bens destinado a tal finalidade, desde que não se trate de atividade puramente intelectual $^{22}$. A organização da produção para o mercado é elemento mandatório, mas a existência de um complexo de bens não é.

Alberto Asquini descreve as dificuldades em estabelecer relação unívoca entre as diferentes concepções econômicas e jurídicas de empresa. $\mathrm{O}$ autor entende que a empresa existe porque as atividades desempenhadas se protraem no tempo, requerendo a figura do empresário, agente tomador de riscos técnicos e econômicos. O empresário exerce função organizadora com o objetivo de produzir para o mercado, podendo, ou não, auferir lucros decorrentes da atividade ${ }^{23}$. Para explicar o tratamento jurídico dado à empresa, Asquini propõe a decomposição em perfis que correspondem, aproximadamente, às acepções jurídicas mais comuns: (i) perfil subjetivo, representado

\footnotetext{
${ }^{20}$ A lei não definiu o significado das expressões "empresa", "filial", "unidade produtiva" e outras (arts. $3^{\circ}$, $36,51,60,140,141,164$ e 166), cabendo ao intérprete a tarefa.

${ }^{21}$ Código Civil, Art. 966. "Considera-se empresário quem exerce profissionalmente atividade econômica organizada para a produção ou a circulação de bens ou de serviços. Parágrafo único. Não se considera empresário quem exerce profissão intelectual, de natureza científica, literária ou artística, ainda com o concurso de auxiliares ou colaboradores, salvo se o exercício da profissão constituir elemento de empresa". Art. 1142. "Considera-se estabelecimento todo complexo de bens organizado, para exercício da empresa, por empresário, ou por sociedade empresária".

${ }^{22}$ Erasmo França esclarece que empresário, segundo o artigo 966 do Código Civil, é aquele que exerce atividade econômica organizada para a produção de bens ou serviços. Estabelecimento, segundo o artigo 1142, é o complexo de bens organizado para o exercício da empresa. A empresa, tomada em sentido estrito, é a atividade econômica organizada, decorrente da conjugação dos artigos 966 e 1142. (FRANÇA, Erasmo Valladão de A e N. Empresa, empresário e estabelecimento. A nova disciplina das sociedades. Revista do Advogado, ano XXIII, n. 71, ago. 2003, p. 18)

${ }^{23}$ Segundo Césare Vivante, o escopo de lucro é natural, mas não é essencial, pois a empresa existe para aumentar a produção e melhorar a distribuição de produtos e serviços. (VIVANTE, Césare, Trattato di diritto commerciale. $5^{\text {a }}$ ed., Milano: Dottor Francesco Vallardi, 1934, Vol. I, pp. 101-102).
} 
pela pessoa do empresário; (ii) perfil funcional, que corresponde à atividade desempenhada; (iii) perfil objetivo, formado pelo conjunto de bens da empresa e pelo estabelecimento empresarial; (iv) perfil corporativo, a organização de pessoas composta pelo empresário e seus colaboradores ${ }^{24}$.

De acordo com a análise proposta por Asquini, pode-se entender que a empresa referida na LREF assemelha-se ao perfil funcional ${ }^{25}$. Entretanto, do ponto de vista dos credores, também interessa o perfil objetivo, os bens que garantem o passivo: os bens empresariais referem-se, principalmente, às relações com terceiros, e o risco econômico mais importante, assumido pelo empresário, diz respeito à possibilidade de cobrir os custos do trabalho e capital empregados, isto é, o risco de não pagar credores ${ }^{26}$.

Tullio Ascarelli entende que a qualificação de empreendedor é dada pela atividade econômica, conjunto de atos coordenados para alcançar determinada finalidade. A atividade, que se desenvolve no tempo, tem valor independente dos atos singulares que a compõem, pode utilizar um conjunto de bens e requer capacidade especial do sujeito que a desenvolve, o empresário. Este é remunerado pelo lucro que compensa os riscos incorridos com o desempenho da atividade. Para Ascarelli, o risco mais importante refere-se ao adimplemento das obrigações assumidas perante terceiros, no exercício da atividade empresarial ${ }^{27}$.

Ronald Coase apresenta a conceituação econômica de empresa, que se aproxima do perfil funcional estabelecido por Asquini $^{28}$ e é coerente com a noção de atividade, proposta por Ascarelli. Coase entende a empresa como feixe de relacionamentos dirigido pelo empresário, cuja principal atividade é organizar trocas no mercado,

${ }^{24}$ ASQUINI, Alberto. Os perfis da empresa. Tradução: COMPARATO, Fabio K. In Revista de Direito Mercantil, Industrial, Econômico e Financeiro, n. 104, pp.109-126.

25 "Talvez o texto legal (que se presume não tenha palavras inúteis) esteja se referindo à empresa enquanto atividade, ou seja, à empresa no sentido funcional, de acordo com os célebres perfis de Asquini. Assim, o que se visaria a atingir, em última análise, seria a preservação da atividade empresarial." (TOLEDO, Paulo F. C. S. de. Recuperação judicial, a principal inovação da Lei de Recuperação de Empresas - LREF. Revista do Advogado, ano XXV, n. 83, set. 2005, p. 103).

${ }^{26}$ ASQUINI, Alberto. Os perfis da empresa. Tradução: COMPARATO, Fabio K. In Revista de Direito Mercantil, Industrial, Econômico e Financeiro, n. 104, pp.110; 124.

${ }^{27}$ ASCARELLI, Tullio, Corso di diritto commerciale - introduzione e teoria dell' impresa. $3^{\text {a }}$ ed., Milano: Giuffrè, 1962, pp.145-164; VERÇOSA, Haroldo M. D. Curso de direito comercial. São Paulo: Malheiros, 2004, vol. 1, pp.52-55.

${ }^{28}$ VERÇOSA, Haroldo M. D. Curso de direito comercial. São Paulo: Malheiros, 2004, vol. 1, p.160. 
reduzindo custos de transação quando há repetição no processo de contratação ${ }^{29}$. Tratase de conjunto organizado de fatores de produção cujo objetivo é aumentar o bem-estar geral por meio da redução dos custos para participar do mercado. O termo usado por Coase é "firm”, que significa "organização" e não "empresa", porque se refere à forma de estruturação da atividade empresarial. Em nosso trabalho, os termos são tomados como equivalentes ${ }^{30}$.

Entendemos que empresa deve ser analisada em sentido objetivo, não no sentido subjetivo. Importa analisar, portanto, o conteúdo patrimonial, não os sujeitos que participam da empresa. Herbert Wiedemann entende, de maneira acertada, que não se devem incluir todos os interesses externos na noção de empresa, sob pena de não mais poder identificar os não abrangidos ${ }^{31,32}$.

A partir dessa diferenciação, é possível entender os conflitos na repartição dos bens da empresa insolvente, pois os interesses dos agentes internos não estão alinhados aos dos demais envolvidos. Os conflitos derivam da escassez de recursos, levando à formação de grupos de interesses. Os custos incorridos dependem do tratamento dado a cada um dos grupos, isto é, da estipulação a respeito de como será a distribuição do valor correspondente aos bens da empresa em crise. Por um lado, há os interesses de

\footnotetext{
${ }^{29}$ Ronald Coase afirma que a organização tem relevância quando é entendida como uma estrutura que depende do empresário e existe para eliminar custos de participação no mercado, principalmente custos relativos ao uso do mecanismo de preços. (COASE, Ronald. "The nature of the firm". In The firm, the market, and the law. Chicago: University of Chicago Press, 1990, pp. 36-39; 41-42)

${ }^{30}$ Para análise das diferenças entre os conceitos, ver: VERÇOSA, Haroldo M. D. Curso de direito comercial. São Paulo: Malheiros, 2004, vol. 1, pp.157-162.

${ }^{31}$ Herbert Wiedemann aponta duas teorias para explicar o interesse social: a subjetiva, que entende empresa como organização social, e a objetiva, que a entende como organização econômica. Na primeira, os interesses são definidos em função dos sujeitos: trabalhadores, administração e sócios representam interesses internos, e externos são os demais. A teoria subjetiva, segundo ele, seria inútil ao direito, pois os interesses de credores, consumidores e comunidade não estão alinhados aos da empresa. Na teoria objetiva, que entende mais adequada, os interesses são definidos em função do objeto, e importa o conteúdo econômico da empresa, não os atores que dela participam. Credores, fornecedores e consumidores têm interesses distintos dos da empresa, e as relações não são de cooperação, mas de conflito, reguladas por contratos que têm o papel de distribuir riscos. Sócios, administradores e empregados têm interesses que podem também ser conflitantes com os da empresa. (WIEDEMANN, Herbert. Gesellschaftsrecht I (Grundlagen). Munique: Beck, 1980, pp. 307-311)

${ }^{32}$ Ver também: WIEDEMANN, Herbert. Excerto do Direito Societário I - Fundamentos. Tradução: Erasmo Valladão de A. e N. França. Revista de Direito Mercantil, Industrial, Econômico e Financeiro, n. 143, pp. 66-75, Jul.-Set. 2006.
} 
administradores e acionistas e, por outro lado, há os interesses de credores ${ }^{33}$.

O feixe de contratos que compõe a empresa é formado por contratos incompletos, os quais apresentam lacunas que se preenchem durante a execução, pois é custoso antecipar todas as contingências no momento em que as cláusulas contratuais são definidas ${ }^{34}$. Contrato é forma pela qual ocorre a circulação de riquezas, um meio para distribuir riscos e realizar trocas de bens entre os agentes. Contratos empresariais, geralmente de longa duração e de execução continuada, servem para simplificar e estabilizar a organização da atividade. Como não é possível antecipar todas as situações possíveis no momento da contratação, faz-se necessário prever regras para completar o contrato em momento posterior ${ }^{35}$. O empresário desempenha o papel de coordenar esse feixe de contratos ao menor custo possível. O procedimento judicial para tratamento da crise deve incluir os contratos empresariais, garantindo a alocação dos riscos previamente estabelecida e decidindo a destinação dos bens em disputa.

Não discutimos em detalhe a função social da empresa. Entretanto, para entender a crise, é necessário estabelecer um significado possível para a expressão ${ }^{36}$.

\footnotetext{
${ }^{33}$ Ronald Coase entende que os custos de transação dependem do tratamento jurídico que se dá aos grupos em conflito. Os custos são de difícil mensuração, mas é possível observar as escolhas dos agentes, porque estas dependem dos custos, tornando o conceito operacional. (COASE, Ronald. "The nature of the firm". In The firm, the market, and the law. Chicago: University of Chicago Press, 1990, pp. 153-156).

${ }^{34}$ SZTAJN, Rachel; ZYLBERSTAJN, Decio; AZEVEDO, Paulo F. "Economia dos contratos". In ZYLBERSTAJN, Decio; SZTAJN, Rachel (coord.). Direito e Economia - Análise Econômica do Direito e das Organizações. São Paulo: Campus, 2005, pp. 102-136.

${ }^{35}$ SZTAJN, Rachel; VERÇOSA, Haroldo M. D. A incompletude do contrato de sociedade. Revista de Direito Mercantil, Industrial, Econômico e Financeiro, Ano XLII, n. 131, Jul./Set. 2003, pp. 7-13.

${ }^{36} \mathrm{O}$ tema é tratado em detalhes nas seguintes obras: CARVALHOSA, Modesto; LATORRACA, Nilton. Comentários à lei de sociedades anônimas. São Paulo: Saraiva, Vols. 2 e 3, 1997, p. 238; COMPARATO, Fabio K. Função social da propriedade dos bens de produção. Revista de Direito Mercantil, Industrial, Econômico e Financeiro, Ano XXV, n. 63, pp. 71-79, jul./set. 1986; Estado, empresa e função social. Revista dos Tribunais, Ano 85, v. 732, out. 1996, pp. 45-46; Aspectos jurídicos da macro-empresa. São Paulo: Revista dos Tribunais, 1970, pp. 85-86; GRAU, Eros R. A ordem econômica na Constituição de 1988. $5^{\text {a }}$ ed., São Paulo: Malheiros, 2000, pp. 253; 259; GULATI, G. Mitu; KLEIN, W. A.; ZOLTI, E. M. Connected Contracts. University of California Law Review, v. 47, 2000. Disponível em http://ssrn.com/abstract=217590. Acesso em: 19.nov.2006, p. 921; JENSEN, M. C.; MECKLING, W. H. Theory of the firm: managerial behavior, agency cost and ownership structure. Journal of Financial Economics, v. 3, n. 4, 1976. Disponível em http://papers.ssrn.com/sol3/paper.taf?abstract_id=94043. Acesso em: 15.mai.2006, p. 9; LOBO, Jorge. Comentários. In TOLEDO, Paulo Fernando Campos Salles de; ABRÃO, Carlos Henrique (coord.). Comentários à lei de recuperação de empresas e falência. São Paulo: Saraiva, 2005, pp. 104-105; PENTEADO, Mauro R. Comentários. In SOUZA JR, Francisco Satiro de; PITOMBO, Antonio Sérgio A de Moraes (coord.). Comentários à lei de recuperação de empresas e falência. São Paulo: Revista dos Tribunais, 2005, pp. 71-73; SALOMÃO FILHO, Calixto. Recuperação de empresas e interesse social. In SOUZA JR, Francisco Satiro de; PITOMBO, Antonio Sérgio A de Moraes (coord.). Comentários à lei de recuperação de empresas e falência. São Paulo: Revista dos Tribunais, 2005, pp. 42-48; 52; SZTAJN,
} 
Rachel Sztajn entende que a função social da empresa integra os parâmetros atuais para a discussão da legislação de quebras, uma vez que inclui a idéia de continuação do negócio e preservação de postos de trabalho, garantindo a produção e distribuição de produtos e serviços no mercado. A autora argumenta que a manutenção da empresa por sua função social tem inspirado a criação de permissividades inexistentes no quadro legal que resultam em externalidades crescentes no mercado ${ }^{37}$. Segundo ela, a função social deve servir para pautar a atuação responsável no domínio econômico, não para substituir o Estado no exercício de suas atribuições. A empresa que cumpre a função social deve balizar-se pela criação de postos de trabalho, respeito ao consumidor, meio-ambiente e coletividade ${ }^{38}$.

A dificuldade prática em conceituar a função social reside no fato de não haver questionamentos econômicos de bem-estar social na LREF, dificultando o entendimento sobre o real significado do papel desempenhado pela recuperação judicial $^{39}$. Como resultado, a função social da empresa continua a ser expressão equívoca cujo significado não foi explicitado pela lei ou pela jurisprudência.

A função social da empresa produtiva é organizar o feixe de contratos de forma a obter o maior rendimento possível. Se há crise, os custos de transação aumentam, reduz-se a qualidade dos bens produzidos, a lucratividade diminui e a empresa perde eficiência, diminuindo o bem-estar geral ${ }^{40}$. A empresa em crise, para cumprir sua

Rachel. Apontamentos em matéria de empresas em crise - falência e liquidação extrajudicial. In SADDI, Jairo (coord.). Intervenção e liquidação extrajudicial no sistema financeiro nacional - 25 anos da Lei 6.024/74. São Paulo: TextoNovo, 1999, pp. 213; 236; Comentários. In SOUZA JR, Francisco Satiro de; PITOMBO, Antonio Sérgio A de Moraes (coord.). Comentários à lei de recuperação de empresas e falência. São Paulo: Revista dos Tribunais, 2005, pp. 220-222; VERÇOSA, Haroldo M. D. Curso de direito comercial. São Paulo: Malheiros, 2004, vol. 1, pp.174-180.

${ }^{37}$ SZTAJN, Rachel. Apontamentos em matéria de empresas em crise - falência e liquidação extrajudicial. In SADDI, Jairo (coord.). Intervenção e liquidação extrajudicial no sistema financeiro nacional - 25 anos da Lei 6.024/74. São Paulo: TextoNovo, 1999, p. 213.

${ }^{38}$ SZTAJN, Rachel. Comentários. In SOUZA JR, Francisco Satiro de; PITOMBO, Antonio Sérgio A de Moraes (coord.). Comentários à lei de recuperação de empresas e falência. São Paulo: Revista dos Tribunais, 2005, pp.220-222.

${ }^{39}$ Milton Barossi Filho entende que a ausência de menção a questionamentos desse tipo dificulta o entendimento sobre o conceito de recuperação adotado pela lei. (BAROSSI FILHO, Milton. As assembléias de credores e plano de recuperação de empresas: uma visão da teoria dos jogos. Revista de Direito Mercantil, Industrial, Econômico e Financeiro, Ano XLIV, n. 137, jan./mar. 2005, p. 236)

${ }^{40}$ As estimativas existentes indicam que os custos de transação derivados da crise da empresa podem ser significativos, inclusive superando o valor da empresa. Michelle White estima que os custos indiretos (perda 
função social, deve ter a capacidade produtiva restaurada por meio da recuperação da empresa viável ou liquidação da inviável. Nenhuma das alternativas implica, necessariamente, na preservação da sociedade empresária que exerce a atividade ${ }^{41}$.

\section{II.2. Crise da empresa.}

Para entender o problema do tratamento jurídico dado à crise da empresa, é necessário saber por que razão existe o débito. Utilizam-se dois argumentos para explicar sua formação: (i) o débito existe porque o devedor precisa endividar-se para saldar compromissos assumidos; (ii) o débito existe porque o empreendedor necessita de capital para desenvolver atividade produtiva que lhe permita obter lucros. A finalidade do débito permite distinguir o devedor-consumidor do devedorempreendedor. O primeiro se endivida para saldar dívidas contraídas, pagando débitos decorrentes de atividades de consumo de bens e serviços. O segundo contrai empréstimos para desenvolver atividade lucrativa, com o objetivo de obter retorno que supere o valor emprestado. A distinção sugere que o empresário assume os riscos da atividade, mas também divide parte dos riscos com os credores, na medida em que investe capital de terceiros em empreendimento que pode não ser bem sucedido. Essa necessidade de endividamento, ou "alavancagem", é essencial à atividade empresarial. Por isso, Lorenzo Stanghellini distingue o "capital de risco" fornecido pelo

de faturamento e clientela, desvalorização dos ativos) são cerca de dez vezes maiores que os custos diretos (custos administrativos e judiciais). (WHITE, Michelle J. The corporate bankruptcy decision. In: POSNER, Richard; PARISI, Francesco, Law and Economics. Cheltenham, UK: Lyme, US: Edward Elgar Publishing, Volume III, pp. 350-351; 360-361). Edward Altman calcula que, em média, os custos diretos são da ordem de $11 \%$ a $17 \%$ do valor total dos ativos. (ALTMAN, Edward I. Corporate financial distress and bankruptcy: a complete guide to predicting and avoiding distress and profiting from bankruptcy. $2^{\text {nd }}$ ed., New York: John Wiley, 1993, pp. 153-154)

${ }^{41}$ A jurisprudência tem se posicionado de maneira diferente. Ver, por exemplo: Câmara Especial de

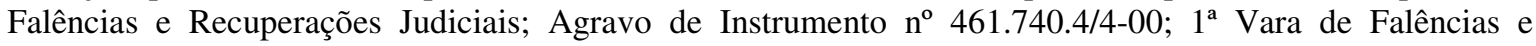
Recuperações Judiciais de São Paulo; Agravante: Banque Marocaine de Commerce Exterieur - BMCE; Agravado: Parmalat Participações do Brasil Ltda. - em recuperação judicial: "Agravo de Instrumento. Plano de Recuperação Judicial rejeitado pela Assembléia-Geral. Pretensão deduzida por credor no sentido de ser decretada a falência da devedora, com base nos artigos 56, $\S 4^{\circ}$ e 73 , inciso III, ambos, da LRF. Soberania das deliberações da Assembléia-Geral de Credores. Decisão que concede prazo para a apresentação de plano alternativo a ser submetido aos credores". "Na aplicação da lei, o Juiz deve atender aos fins sociais a que ela se dirige e às exigências do bem comum (artigo $5^{\circ}$, LICC). O Juiz não é mero chancelador ou homologador das deliberações assembleares, devendo examiná-las sob a óptica do princípio constitucional da função social da empresa que, por isso, deve ser preservada. A preservação da empresa é o maior princípio da Lei $n^{o} 11.101 / 2005$, não se olvidando que os princípios têm peso e densidade, devendo ser mensurados. Violar um princípio é mais grave do que violar uma regra, mercê do que, havendo conflito entre um princípio e uma regra, o Juiz deve dar prevalência ao princípio. Agravo desprovido." (itálicos nossos) 
empreendedor do "capital de débito" providenciado pelos credores, os "sócios sem direitos" ${ }^{42}$.

Por um lado, o valor do negócio depende de sua capacidade de produzir riqueza, não da titularidade jurídica sobre o capital. Por outro lado, a composição do capital adquire importância quando é necessário atribuir valor ao conjunto de bens, direitos e obrigações. A empresa alavancada traz mais benefícios ao empreendedor e mais riscos aos credores porque, em caso de sucesso da atividade, permite ao primeiro maximizar lucros, mas aumenta o risco dos credores se o empreendimento fracassa ${ }^{43}$.

Este é um dos principais problemas de qualquer sistema concursal: em caso de sucesso do empreendimento, os ganhos são, em grande parte, apropriados pelo devedor, mas, em caso de fracasso, há perdas suportadas pelos "sócios sem direitos". Argumenta-se que o credor racional irá precaver-se contra o risco de perdas aumentando as taxas de juros sobre os empréstimos concedidos ao devedor. A afirmação, se aceita, pode justificar a existência de um sistema concursal no qual devedor e credores têm certeza de que os contratos firmados serão respeitados, mantendo-se a proporção de riscos assumidos pelos detentores de capital de risco e de capital de débito, estabelecida antes da crise.

A crise pode ter causas econômicas, financeiras ou patrimoniais, decorrentes de situações temporárias ou permanentes, de mercado ou estruturais. A multiplicidade de possibilidades dificulta a uniformização de regras para identificá-la e resolvê-la.

É necessário haver tutela preventiva (ex ante) e corretiva (ex post) da crise. A segunda corresponde ao tratamento jurídico previsto em lei, depois de instalada a crise. Já a primeira refere-se à existência de critérios para identificação antecipada de sinais da crise, percebidos a tempo de minimizar ou evitar prejuízos.

A LREF disciplina o tratamento corretivo, mas não apresenta regras de

${ }^{42}$ STANGHELLINI, Lorenzo. Crisi di impresa fra diritto ed economia - le procedure di insolvenza. Bologna: Il Mulino, 2007, pp. 15-33.

${ }^{43}$ Ibid, pp. 32-33. 
tratamento preventivo. $\mathrm{O}$ direito societário não costuma estabelecer a tutela preventiva de crises, salvo exceções, por exemplo, o regime legal de intervenção extrajudicial em instituições financeiras ${ }^{44}$.

A respeito da tutela preventiva, Lorenzo Stanghellini entende que a perda de capital abaixo do limite mínimo é indicação prévia de sintomas de crise e deveria autorizar o ordenamento jurídico a intervir na empresa sem ter que aguardar o agravamento do problema ${ }^{45}$.

Rachel Sztajn também entende que a adoção de disciplina de capital mínimo auxilia a tutela ex ante da crise, pois obriga à recomposição dos valores nominais do capital social quando há prejuízos que venham a reduzi-lo, sob pena de tornar ilimitada a responsabilidade dos sócios. A autora indica, ainda, que a facilidade na constituição de sociedades que admitem a limitação da responsabilidade dos sócios pelas obrigações sociais pode contribuir para aumentar a irresponsabilidade na condução dos negócios, aumentando a tendência dos administradores em assumir riscos, uma vez que os bens destes e do devedor estão razoavelmente protegidos contra execução pelos credores ${ }^{46}$.

Luca Enriques e Martin Gelter propõem mecanismo inovador de tutela preventiva para autorizar o credor a obter salvaguardas ou novas garantias para os empréstimos quando o devedor pretende realizar operação no mercado capaz de aumentar, substancialmente, o endividamento e o risco de recebimento futuro dos créditos ${ }^{47}$. A proposta permite realizar o completamento posterior do contrato estipulado com o devedor, ajustando o nível de exposição a riscos dos credores antes da instalação da crise.

\footnotetext{
${ }^{44}$ Ver Lei n. 6.024/74 e Lei n. 9.447/97.

${ }^{45}$ STANGHELLINI, Lorenzo. Crisi di impresa fra diritto ed economia - le procedure di insolvenza. Bologna: Il Mulino, 2007, pp. 154-155.

${ }^{46}$ SZTAJN, Rachel. Apontamentos em matéria de empresas em crise - falência e liquidação extrajudicial. In SADDI, Jairo (coord.). Intervenção e liquidação extrajudicial no sistema financeiro nacional - 25 anos da Lei 6.024/74. São Paulo: TextoNovo, 1999, pp. 217-220.

${ }^{47}$ ENRIQUES, Luca; GELTER, Martin. How the old world encountered the new one: regulatory competition and cooperation in European corporate and bankruptcy law. European Corporate Governance Institute (ECGI), Working Paper Series in Law, n. 63/2006, February 2006. Disponível em $<$ http://ssrn.com/abstract=887164>. Acesso em: 06.ago.2007, p.28.
} 
Com relação à tutela repressiva, Riccardo Rossi mostra que a crise, em geral, é identificada por sinais exteriores, sob a forma de atrasos ou suspensão dos pagamentos de curto prazo. Entretanto, os sinais podem não refletir verdadeira crise, mas servir como indicativos de problemas temporários de fluxo de caixa. O autor entende que, para distinguir a crise permanente da temporária, é preciso analisar as condições de rentabilidade da empresa ${ }^{48}$.

Para Rossi, o critério da rentabilidade permite analisar a eficiência da empresa pelo prisma econômico. A rentabilidade é observada apenas em relação ao presente e passado, mas, para o futuro, é possível fazer projeções, não havendo garantias de que os resultados passados se repetirão. Se houver crise de mercado, avanços tecnológicos ou mudanças nas preferências dos consumidores, a rentabilidade futura pode não existir $^{49}$. Para ser efetiva, a análise proposta por Rossi deve considerar período de tempo suficiente para atestar a capacidade da empresa em gerar resultados de forma consistente, permitindo entender o negócio pelo prisma da geração de fluxo de caixa positivo e pela qualidade dos projetos de investimento futuro da empresa.

Lorenzo Stanghellini entende que o estado de crise se manifesta quando o insolvente demonstra incapacidade de adimplir as obrigações "com regularidade", não sendo condição necessária a constatação de inadimplemento definitivo ${ }^{50}$. O critério proposto por ele depende de saber o que se entende por "regularidade".

Outra classificação possível sugere a diferenciação da crise econômica, financeira e patrimonial. A financeira é a incapacidade de equilibrar despesas e receitas, podendo ter como conseqüência a crise. É possível identificar a crise financeira pela incapacidade de realizar investimentos, pois decorre da ausência de meios de

\footnotetext{
${ }^{48}$ ROSSI, Riccardo. Insolvenza, crisi di impreza e risanamento. Milano: Giuffrè, 2003, p. 114.

${ }^{49}$ Há sempre a possibilidade de fatores externos, não controlados pelo devedor ou credores, causarem a crise. É o caso, por exemplo, da empresa responsabilizada por fato do produto, segundo a lei consumerista (art. 12 da Lei n. 8.078/90), com ações judiciais indenizatórias que inviabilizem a continuidade do negócio. Exemplo é o da Manville Corporation, produtora de amianto, produto que foi considerado danoso ao meio ambiente e às pessoas. A empresa era lucrativa, mas foi à falência nos Estados Unidos, acumulando passivo com indenizações judiciais da ordem de dois bilhões de dólares, enquanto os ativos valiam a metade desse valor. (ALTMAN, Edward I. Corporate financial distress and bankruptcy: a complete guide to predicting and avoiding distress and profiting from bankruptcy. $2^{\text {nd }}$ ed., New York: John Wiley, 1993, p. 451).

${ }^{50}$ STANGHELLINI, Lorenzo. Crisi di impresa fra diritto ed economia - le procedure di insolvenza. Bologna: Il Mulino, 2007, pp. 119-121.
} 
financiamento da atividade, causada por mudanças no mercado ou nos hábitos dos consumidores $^{51,52}$.

A crise patrimonial deriva do desequilíbrio entre ativos e passivos, colocando em risco o pagamento aos credores. A identificação da crise, unicamente por esse critério, pode levar a decisões equivocadas, pois o déficit pode ser apenas temporário.

Podemos perceber a crise financeira e a crise patrimonial nas informações contidas no balanço patrimonial e nos demonstrativos financeiros, mas esses documentos não permitem diferenciar a empresa eficiente da ineficiente. As informações contábeis e financeiras são produzidas pelo devedor e não refletem a real situação dos negócios nem as condições futuras do mercado, uma vez que representam informações sobre o passado ${ }^{53}$.

Outro critério, insuficiente para a identificação da crise, é a incapacidade para realizar investimentos, pois pode haver mero desinteresse dos acionistas em investir. Além disso, trata-se de situação de difícil observação pelos credores, em especial nas

${ }^{51}$ ROSSI, Riccardo. Insolvenza, crisi di impreza e risanamento. Milano: Giuffrè, 2003, pp. 130-135; GARDINO, Adriana V. P. A evolução do tratamento jurídico da empresa em crise no direito brasileiro. Dissertação de Mestrado, São Paulo: Faculdade de Direito da Universidade de São Paulo, 2006, p. 137.

${ }_{52}$ Fabio Coelho entende que a crise econômica ocorre quando há retração nos negócios, queda de faturamento ou atraso tecnológico. $\mathrm{O}$ autor entende que a crise pode ser generalizada, segmentada ou atingir somente uma empresa. Explica que crise financeira é insuficiência de caixa para honrar compromissos, crise de liquidez que se exterioriza pela impontualidade, podendo ocorrer, por exemplo, quando a empresa não amortizou o capital investido ou está endividada em moeda estrangeira e sobrevém mudança cambial acentuada. Ele entende que crise patrimonial é aquela na qual o ativo é inferior ao passivo, crise estática que não indica, por exemplo, que o déficit pode ser causado por decisões de investimento, tomadas de forma racional. Conclui que os indicadores são relativos e nem sempre se revelam úteis. (COELHO, Fabio U. Comentários à nova lei de falências e de recuperação de empresas. São Paulo: Saraiva, 2005, pp. 22-25) Tal explicação é apenas parcialmente correta, porque utiliza soluções casuísticas que nem sempre se revelam úteis para avaliar a crise da empresa. Ver críticas a tal raciocínio, elaboradas por CALABRESI e MELAMED (seção I.4).

${ }^{53}$ Fabio Comparato entende que "(a) verdade contábil é, pois, simplesmente relativa. O lucro do balanço, por exemplo, é uma realidade meramente contábil e abstrata. A ocorrência de lucros de exploração e o seu exato montante, a rigor, só podem ser verificados, realmente, quando a empresa se extingue e se apura o resultado final. (...) Quem poderá medir com precisão, sobretudo em conjunturas inflacionárias, o valor de um ativo patrimonial, malgrado as reavaliações e depreciações consentidas? Como excluir, portanto, a realidade das reservas ocultas, cuja manutenção, aliás, é considerada por muito administrador de empresas ativo e probo (Decreto-Lei n. 2.627 , art. $116, \$ 7^{\circ}$ ) como garantia indispensável contra eventuais perdas futuras?" (COMPARATO, Fabio K. Natureza jurídica do balanço. In Ensaios e pareceres de direito empresarial. Rio de Janeiro: Forense, 1978, pp. 29-32) 
empresas de capital fechado, nas quais há dificuldade em revelar informações ${ }^{54}$.

A crise econômica traduz-se na incapacidade de obtenção de meios de financiamento da atividade. A empresa pode não apresentar desequilíbrio financeiro nem sinais imediatos de desinvestimento ou cancelamento de projetos. Acionistas e credores podem não desejar realizar novos investimentos pelas mais variadas razões, nem sempre associadas à percepção de crise. Para os credores, investigar os motivos de desinteresse é tarefa de difícil execução, pois, muitas vezes, a informação é de conhecimento exclusivo do devedor.

O critério econômico-financeiro combina os anteriores, tornando-o de mais fácil identificação pelos credores. Entretanto, também pode ser decorrente de crise de mercado ou de mudanças nas preferências dos consumidores, que, nem sempre, dependem de atitudes do devedor.

A dificuldade em encontrar critério inequívoco para identificar a crise também decorre de diferenças metodológicas de interpretação dos sinais de crise, realizada por juristas e economistas. Para o direito, há três tipos de crise: a econômica, a financeira e a patrimonial. Para a economia, a última é espécie de crise financeira. Para os economistas, crise financeira relaciona-se a liquidez, ao passo que para os juristas é crise de natureza patrimonial. Liquidez representa a dificuldade em transformar bens em dinheiro, de forma rápida e sem perdas, podendo ou não haver desbalanceamento entre ativos e passivos. A iliquidez e o desbalanceamento podem ser resolvidos com técnicas de engenharia financeira e, por isso, os economistas não distinguem a crise financeira da patrimonial. Os juristas, entretanto, observam o problema pela ótica do credor: a crise patrimonial significa insuficiência de ativos, afetando as garantias para saldar dívidas contraídas; por essa razão, é distinta da crise financeira ${ }^{55}$.

\footnotetext{
${ }^{54}$ Por exemplo, a Lei de Sociedades Anônimas (LSA) dá novo tratamento à questão da demonstração de fluxos de caixa das companhias. A lei n. 11.638, de 2007, alterou o caput do art. 176 da LSA, indicando que, ao fim de cada exercício social, a diretoria passará também a elaborar a demonstração dos fluxos de caixa da companhia, exprimindo com clareza a situação do patrimônio e as mutações ocorridas no exercício. A mesma lei, entretanto, dispensa a companhia fechada com patrimônio líquido, na data do balanço, inferior a dois milhões de reais, da obrigação de elaboração e publicação da demonstração de fluxos de caixa (art. 176, $\S 6^{\circ}$ ). ${ }^{55}$ A respeito da distinção, ver também: SZTAJN, Rachel. Comentários. In SOUZA JR, Francisco Satiro de; PITOMBO, Antonio Sérgio A de Moraes (coord.). Comentários à lei de recuperação de empresas e falência. São Paulo: Revista dos Tribunais, 2005, p. 219.
} 
Importante também é a distinção entre insolvência e insolvabilidade. A primeira refere-se ao déficit patrimonial, desbalanceamento entre ativos e passivos. A segunda é a ausência de liquidez para honrar compromissos de forma tempestiva. O comerciante pode ser insolvente e, ainda assim, porque dispõe de crédito no mercado, conseguir saldar as dívidas correntes, evitando a impontualidade, esta, uma das condições jurídicas para decretação da falência ${ }^{56}$.

Tendência moderna é o relativo abandono de técnicas tradicionais de análise de concessão de empréstimo baseadas em informações de balanço, substituídas pela análise de fluxo de caixa e avaliação de "riscos fora do balanço". A análise tradicional de crédito avalia a empresa, razões do empréstimo, demonstrativos financeiros, fluxo de caixa, capacidade de pagamento, estrutura do setor, capacitação dos administradores, estratégia operacional, garantias dadas aos empréstimos, formas de securitização e documentação apresentada. Outra possibilidade é a utilização de modelos matemáticos que apontam o risco de crédito. Ambos são procedimentos demorados, dispendiosos, apresentam certo grau de subjetividade e são passíveis de erros de avaliação $^{57,58}$.

Riccardo Rossi introduz a noção de "estados patológicos", sintomas indicativos de existência da crise. Ele os descreve da seguinte maneira: (i) crise de ineficiência: desalinhamento entre o rendimento produtivo e comercial do negócio, em relação aos concorrentes; a empresa em crise apresenta custos superiores à média do setor; (ii) crise de excesso de capacidade: redução do volume da demanda consolidada com conseqüente contração do resultado e dos lucros, decorrente de excesso de capacidade produtiva do setor ou redução da participação no mercado; (iii) crise de redução de produtividade: diminuição da margem entre receitas e despesas, não atribuível a um produto específico, de tal monta que não cobre os custos fixos; (iv) crise de falta de

\footnotetext{
${ }^{56}$ Ver: PENTEADO, Mauro R. Comentários. In SOUZA JR, Francisco Satiro de; PITOMBO, Antonio Sérgio A de Moraes (coord.). Comentários à lei de recuperação de empresas e falência. São Paulo: Revista dos Tribunais, 2005, pp. 77-78.

${ }^{57}$ CAOUETTE, John B.; ALTMAN, Edward I.; NARAYANAN, Paul. Gestão do risco de crédito, Rio de Janeiro: Qualitimark, 2000, pp. 95-107; 117-126.

${ }^{58}$ Dois exemplos de técnicas alternativas são o modelo de avaliação de risco de crédito proposto por Edward Altman (Corporate financial distress and bankruptcy: a complete guide to predicting and avoiding distress and profiting from bankruptcy. $2^{\text {nd }}$ ed., New York: John Wiley, 1993, pp. 179-206) e o modelo de previsão de falências de Stephen Kanitz (Como prever falências. São Paulo: McGraw-Hill, 1978).
} 
inovação: dificuldade substancial de adaptação dos produtos e serviços às mudanças do mercado e às novas preferências dos consumidores. Segundo Rossi, dependendo da gravidade dos diversos estados combinados, a crise pode ser reversível (temporária) ou irreversível (definitiva), sem preponderância de qualquer delas ${ }^{59}$.

Para Rossi, a temporariedade ou definitividade da crise está atrelada ao grau de dependência entre o equilíbrio econômico e o financeiro, sendo que o primeiro se manifesta somente quando o segundo existe ${ }^{60}$. Ele entende ser aplicável a teoria do valor para identificar se a crise é temporária ou definitiva. Segundo tal teoria, o objetivo fundamental da empresa é aumentar o valor do capital econômico e, nesse sentido, a "patologia" apresentada pode indicar mero declínio ou crise efetiva. O declínio indica fenômeno degenerativo, variação negativa do valor econômico que, se não equacionada a tempo, leva à irreversibilidade do quadro. A crise efetiva representa um declínio relevante, decorrente de intenso processo de erosão do valor do capital. Segundo ele, o momento de passagem de um estado a outro é de difícil identificação ${ }^{61}$.

A proposta de Rossi pressupõe atribuir valor à empresa, tarefa complexa e subjetiva quando o fluxo de renda é desconhecido ou incerto. As trocas econômicas resultam de as partes tentarem determinar, em relação aos ativos negociados, quais atributos dos bens têm valor e a utilidade da troca. Entretanto, é difícil delimitar os direitos sobre atributos dos bens e seu valor, devido aos custos de medição. Quanto mais facilmente se pode afetar o fluxo de renda de um ativo sem incorrer em custos, mais baixo será o valor. Os custos, por sua vez, dependem da propriedade sobre os atributos e da capacidade dos agentes em capturá-los. Os ativos são mais controláveis quando o fluxo de renda pode ser mensurado, uma vez que é possível estabelecer o preço pelo benefício produzido. Quando o fluxo é desconhecido, inconstante ou imprevisível, há dificuldade em assegurar direitos ${ }^{62}$.

A LREF não define o significado de crise da empresa, apenas indica as

\footnotetext{
${ }^{59}$ ROSSI, Riccardo. Insolvenza, crisi di impreza e risanamento. Milano: Giuffrè, 2003, pp. 125-127; 139.

${ }^{60}$ Ibid, pp. 142-143.

${ }^{61}$ Ibid, pp. 146-151.

${ }^{62}$ NORTH, Douglass C. Institutions, institutional change and economic performance. New York: Cambridge University Press, 2002, pp. 29-31.
} 
manifestações exteriores que considera relevantes para determinar o estado de crise. Em relação à recuperação judicial (arts. 47 e 48), não elenca critérios que permitam identificar a crise passageira da empresa recuperável, distinguindo-a da crise irremediável. Da leitura de tais artigos, pode-se entender que a lei sinaliza ser a empresa em crise provavelmente um negócio viável; o pedido de recuperação, direito exclusivo do devedor, não deve ser indeferido senão por descumprimento dos requisitos formais do art. $48^{63}$. Além disso, a jurisprudência tem entendido que o ato que defere o processamento da recuperação tem natureza de despacho de mero expediente, de natureza irrecorrível, não permitindo questionamentos prévios a respeito da inviabilidade da recuperação ${ }^{64,65}$. Tal posicionamento implica em admitir que os custos decorrentes do procedimento concursal devam ser incorridos para se chegar à decisão a respeito da viabilidade do empreendimento.

A LREF não define critérios objetivos de análise da viabilidade econômica da recuperação que devam ser considerados pelo juiz para deferimento do pedido. Essa análise (art. 53, II) e o laudo de avaliação de bens ou ativos (art. 53, III) são eventos

\footnotetext{
${ }^{63}$ LREF, Art. 47. "A recuperação judicial tem por objetivo viabilizar a superação da situação de crise econômico-financeira do devedor, a fim de permitir a manutenção da fonte produtora, do emprego dos trabalhadores e dos interesses dos credores, promovendo, assim, a preservação da empresa, sua função social e o estímulo à atividade econômica". Art. 48. "Poderá requerer recuperação judicial o devedor que, no momento do pedido, exerça regularmente suas atividades há mais de 2 (dois) anos e que atenda aos seguintes requisitos, cumulativamente: I - não ser falido e, se o foi, estejam declaradas extintas, por sentença transitada em julgado, as responsabilidades daí decorrentes; II - não ter, há menos de 5 (cinco) anos, obtido concessão de recuperação judicial; III - não ter, há menos de 8 (oito) anos, obtido concessão de recuperação judicial com base no plano especial de que trata a seção V deste capítulo; IV - não ter sido condenado ou não ter, como administrador ou sócio controlador, pessoa condenada por qualquer dos crimes previstos nesta Lei. Parágrafo único. A recuperação judicial também poderá ser requerida pelo cônjuge sobrevivente, herdeiros do devedor, inventariante ou sócio remanescente".

${ }^{64}$ Câmara Especial de Falências e Recuperações Judiciais; Agravo de Instrumento no $533.546 .4 / 8-00 ; 3^{\text {a }}$ Vara Cível de Itu; Agravante: Daniele Banco Fomento Comercial e Participações Ltda.; Agravado: Ecimex Tecnologia Ltda.; Ecitec Indústria e Comércio Ltda. e Ecimex Tecnologia do Nordeste Ltda., todas em recuperação judicial: "Recuperação Judicial. Pronunciamento judicial que apenas defere o processamento. Agravo de instrumento que ataca o deferimento do processamento, sob o argumento de que o Juízo é incompetente, as agravadas não exercem suas atividades com probidade, a petição inicial não está instruída com os documentos exigidos pelo artigo 51, incisos III e IX da Lei $\mathrm{n}^{\circ}$ 11.101/2005. Agravo não conhecido, com recomendação para o Juízo examinar a questão da competência que é funcional e absoluta."

${ }^{65}$ Tribunal de Justiça de São Paulo - Seção de Direito Privado; Agravo de Instrumento n. ${ }^{\circ}$ 428.507.4/0-00 e Agravo de Instrumento n. $.^{\circ} 428.805 .4 / 0-00$ - Voto n. ${ }^{\circ}$ 6.216): (...) "Ainda que sejam abissais as diferenças entre a recuperação judicial e a concordata preventiva, é certo que, no ponto, ou seja, despacho que defere o processamento de ambos os institutos, a doutrina falencista não vislumbrou nenhuma diferença, tanto que, unissonamente, proclamou que o despacho que apenas defere o processamento da recuperação judicial nada decide, isto é, não é sequer decisão interlocutória, visto que não resolve qualquer questão incidente (cf. art. $162, \S 2^{\circ}$, do CPC), e sim apenas impulsiona o processo, é despacho de mero expediente, e, nessas condições, irrecorrível (art. 504 do CPC)".
} 
posteriores que ocorrem somente quando da apresentação definitiva do plano de salvação pelo devedor, sessenta dias após o deferimento do processamento do pedido de recuperação ${ }^{66}$. Dessa forma, mesmo quando há sérias dúvidas a respeito da capacidade de recuperação da empresa, o juiz deferirá o pedido, pois a lei outorgou aos credores reunidos em assembléia geral a decisão final sobre o reconhecimento da viabilidade da empresa.

Em relação à falência, a lei não inova de modo significativo na detecção dos sinais de crise. O pedido de falência configura-se em três situações: (i) impontualidade, identificada pelo não pagamento de dívidas vencidas (art. 94, inciso I) cujo valor ultrapasse quarenta salários mínimos na data do pedido; (ii) execução frustrada, quando o devedor interpelado não paga nem garante o pagamento de dívida vencida (art. 94, inciso II); (iii) prática de atos de falência, comportamentos do devedor que fazem presumir o estado de crise (art. 94, inciso III) ${ }^{67}$.

O artigo 94 indica a opção pelo critério da presunção legal de falência, que pode não corresponder à insolvabilidade econômica. A impontualidade e a execução frustrada (incisos I e II) podem denotar apenas estados temporários de iliquidez, decorrentes de insuficiência momentânea de caixa ${ }^{68}$, podendo ser elididos pelo depósito

\footnotetext{
${ }^{66}$ LREF, Art. 53. "O plano de recuperação será apresentado pelo devedor em juízo no prazo improrrogável de 60 (sessenta) dias da publicação da decisão que deferir o processamento da recuperação judicial, sob pena de convolação em falência, e deverá conter: (...) II - demonstração de sua viabilidade econômica;".

${ }^{67}$ LREF, Art. 94. "Será decretada a falência do devedor que: I - sem relevante razão de direito, não paga, no vencimento, obrigação líquida materializada em título ou títulos executivos protestados cuja soma ultrapasse o equivalente a 40 (quarenta) salários-mínimos na data do pedido de falência; II - executado por qualquer quantia líquida, não paga, não deposita e não nomeia à penhora bens suficientes dentro do prazo legal; III pratica qualquer dos seguintes atos, exceto se fizer parte de plano de recuperação judicial: a) procede à liquidação precipitada de seus ativos ou lança mão de meio ruinoso ou fraudulento para realizar pagamentos; b) realiza ou, por atos inequívocos, tenta realizar, com o objetivo de retardar pagamentos ou fraudar credores, negócio simulado ou alienação de parte ou da totalidade de seu ativo a terceiro, credor ou não; c) transfere estabelecimento a terceiro, credor ou não, sem o consentimento de todos os credores e sem ficar com bens suficientes para solver seu passivo; d) simula a transferência de seu principal estabelecimento com o objetivo de burlar a legislação ou a fiscalização ou para prejudicar credor; e) dá ou reforça garantia a credor por dívida contraída anteriormente sem ficar com bens livres e desembaraçados suficientes para saldar seu passivo; f) ausenta-se sem deixar representante habilitado e com recursos suficientes para pagar os credores, abandona estabelecimento ou tenta ocultar-se de seu domicílio, do local de sua sede ou de seu principal estabelecimento; g) deixa de cumprir, no prazo estabelecido, obrigação assumida no plano de recuperação judicial (...)".

${ }^{68}$ No mesmo sentido: FRANCO, Vera Helena de Mello. Comentários. In SOUZA JR, Francisco Satiro de; PITOMBO, Antonio Sérgio A de Moraes (coord.). Comentários à lei de recuperação de empresas e falência. São Paulo: Revista dos Tribunais, 2005, pp. 393-394.
} 
integral do montante devido (art. 98, parágrafo único ${ }^{69}$ ).

Da mesma forma, os atos de falência (inciso III) podem indicar situações que não implicam em situação irremediável. Assim, por exemplo, a lei isenta o devedor da prática de certos atos considerados falimentares, porque realizados em sede de recuperação judicial (art. 94, III, parte final), o que não significa que permita que o devedor utilize-se de expedientes oportunistas para impor perdas aos credores ${ }^{70}$.

Também a detecção do estado de crise dentro do termo legal da falência (art. 99, $\left.\mathrm{II}^{71}\right)$ não é tratada de forma adequada pela lei. O termo legal é de, no máximo, noventa dias, insuficiente para coibir todo tipo de abuso do devedor. O devedor, em geral, conhece o estado de crise muito antes do prazo legal, que pode ser curto demais para evitar a prática de atos abusivos, realizados com o objetivo de prejudicar credores. Uma vez que ele detém informação assimétrica ${ }^{72}$ a respeito do próprio negócio, o credor e o juiz terão dificuldade em identificar, com segurança, se as atitudes do devedor, praticadas antes do termo legal da falência, são legítimas.

O pedido de falência restou enfraquecido pela nova lei. Com base no art. 95, no

\footnotetext{
${ }^{69}$ LREF, Art. 98. "Citado, o devedor poderá apresentar contestação no prazo de 10 (dez) dias. Parágrafo único. Nos pedidos baseados nos incisos I e II do caput do art. 94 desta Lei, o devedor poderá, no prazo da contestação, depositar o valor correspondente ao total do crédito, acrescido de correção monetária, juros e honorários advocatícios, hipótese em que a falência não será decretada e, caso julgado procedente o pedido de falência, o juiz ordenará o levantamento do valor pelo autor".

70 "Alguns, porque o bom senso denuncia que, v.g., o 'lançar mão de meio ruinoso ou fraudulento para realizar pagamentos' com toda certeza não conta com o beneplácito do direito”. (FRANCO, Vera Helena de Mello. Comentários. In SOUZA JR, Francisco Satiro de; PITOMBO, Antonio Sérgio A de Moraes (coord.). Comentários à lei de recuperação de empresas e falência. São Paulo: Revista dos Tribunais, 2005, pp. 393394).

${ }^{71}$ LREF, Art. 99. “A sentença que decretar a falência do devedor, dentre outras determinações: (...) II - fixará o termo legal da falência, sem poder retrotraí-lo por mais de 90 (noventa) dias contados do pedido de falência, do pedido de recuperação judicial ou do $1^{\circ}$ (primeiro) protesto por falta de pagamento, excluindo-se, para esta finalidade, os protestos que tenham sido cancelados”.

${ }^{72}$ A premissa dos modelos econômicos neoclássicos é que os agentes possuem informação completa para tomada de decisão. A realidade, entretanto, é diferente. A informação assimétrica é a característica freqüentemente presente e explica a razão de vários arranjos institucionais. George Akerlof demonstrou que, em mercados nos quais o comprador se utiliza de estatísticas para avaliar a qualidade dos produtos, há incentivos para vendedores comercializarem mercadorias de baixa qualidade, pois o retorno obtido é o mesmo para todos. Em conseqüência, haveria tendência de redução da qualidade das mercadorias e do tamanho do mercado. Como os retornos sociais e privados são diferentes, seria necessária a intervenção governamental para aumentar o bem-estar geral. O exemplo clássico é o mercado de carros usados de má qualidade ("lemons"), no qual o vendedor detém melhores informações sobre a qualidade do bem negociado. Tal aspecto da incerteza é explorado pela teoria dos jogos no dilema do prisioneiro. (AKERLOF, George. The market for lemons: quality uncertainty and the market mechanism. Quarterly Journal of Economics. V. 84, n. 3, August, 1970, p. 488).
} 
prazo da contestação do pedido, o devedor pode evitar a falência pleiteando a recuperação judicial ${ }^{73}$. A lei parece ser rígida na identificação do estado de falência, mas permite sua conversão em recuperação no prazo da contestação, que é de dez dias (art. 98), desde que o devedor cumpra as formalidades do art. 48.

Não há regras de tutela preventiva da crise na LREF. A lei não traz normas para detectá-la antes da instauração do procedimento concursal. Além disso, a disciplina brasileira de direito societário, salvo exceções, não exige subscrição de capital mínimo para a constituição e funcionamento das sociedades ${ }^{74}$, inviabilizando a tutela preventiva quando, por exemplo, a empresa, que ainda não apresenta sinais exteriores de crise, endivida-se em demasia, comprometendo sua sobrevivência, deteriorando as garantias e aumentando o risco para os credores.

Da breve exposição, podemos concluir que a lei não fixa critérios seguros para detectar a crise e também não distingue as crises patrimonial, financeira e econômica.

Nenhuma dos critérios apresentados, entretanto, elimina a possibilidade de ocorrência de erros de avaliação, pois as causas reais da crise, em grande parte, são informações assimétricas não reveladas pelo devedor. Em contrapartida, a combinação de critérios pode indicar maior ou menor probabilidade de acerto da análise, mas não impede a ocorrência de erros de avaliação ${ }^{75}$.

Os sinais indicativos da crise surgem antes do pedido de recuperação ou falência, mas não são exteriorizados. $\mathrm{O}$ devedor sabe mais a respeito do próprio negócio que os credores ou o juiz, tendendo a acreditar que a crise é passageira. Entretanto, parte dos credores tem propensão a acreditar que a situação é sempre irremediável. São as atitudes do devedor, combinadas com mecanismos de revelação de informações, que podem indicar aos credores a gravidade da crise.

Empresa eficiente é aquela que não apresenta crise econômica, apenas

\footnotetext{
${ }^{73}$ LREF, Art. 95. "Dentro do prazo de contestação, o devedor poderá pleitear sua recuperação judicial”.

${ }^{74}$ Há exceções, como por exemplo, o regime de capitalização e formas de sua integralização para as instituições financeiras autorizadas pelo Banco Central.

${ }^{75}$ Seção II.3.
} 
desequilíbrio momentâneo no fluxo de caixa, devendo ser recuperada. A ineficiente, ao contrário, passa por crise irremediável e deve ser liquidada.

A distinção entre as duas espécies de empresa deve ser realizada por comparação, segundo critérios como rentabilidade, custos, receitas, fluxo de caixa, projetos de investimento e posição relativa no mercado. Comparam-se os resultados produzidos pela empresa em crise com os que seriam obtidos se houvesse realocação dos ativos para outros empreendimentos ${ }^{76}$.

Não há estudos empíricos adequados para realizar tal comparação, tornando complexa a tarefa de identificação e análise da crise das empresas brasileiras ${ }^{77,}$ 78, 79 .

\footnotetext{
${ }^{76}$ WHITE, Michelle J. Corporate bankruptcy as a filtering device: Chapter 11 reorganizations and out-ofcourt debt restructurings. Journal of Law, Economics and Organization, n. 10, pp. 268-295, 1984.

${ }^{77}$ Aloísio Araújo e Bruno Funchal, com base em dados coletados pelo Banco Mundial, apontam que os indicadores históricos do Brasil com respeito à proteção aos credores, recuperação dos créditos e duração do procedimento concursal, estão entre os piores da América Latina. (ARAÚJO, Aloísio Pessoa de; FUNCHAL, Bruno. Bankruptcy law in Latin America: past and future. Economia, n. 599, pp. 149-216, Agosto 2005. Disponível em <http://epge.fgv.br/portal/pt/pesquisa/producao/1922.html>. Acesso em: 05.set.2007; Recuperação de empresas: uma múltipla visão da nova lei - Lei 11101/05 de 09.02.2005, in Reflexões a partir da Lei no 11.101/05 - O impacto econômico da nova Lei de Falência e Recuperação de Empresas. Vol. 1, pp. 32-42, 2006. Disponível em <http://epge.fgv.br/we/brunofunchal>. Acesso em: 05.set.2007)

${ }^{78}$ Dados estrangeiros são inadequados para análise da situação de empresas brasileiras, mas servem como indicação de tendência. Michelle White realizou, entre 1983 e 1984, estudo com empresas norte-americanas que entraram com pedido de falência e recuperação, demonstrando que os índices de cobertura do passivo das primeiras eram piores que os das segundas. Foram estudadas em 1983, utilizando-se estatísticas geradas pelo Departamento de Justiça, 500 empresas que entraram com pedido de falência e 500 que entraram com pedido de recuperação para analisar os indicadores de: total do passivo sobre o ativo; e total dos ativos com garantia sobre total do ativo. Outro estudo, realizado em 1984 com 90 empresas que entraram com pedido de falência e 64 que entraram com pedido de recuperação, coletou indicadores de média de pagamentos a credores com e sem garantia. Não foram separadas as amostras dos estudos e a pesquisa realizada diretamente por White (a de 1984) não separa dados de grandes e pequenas empresas. A autora adverte que os dados não são conclusivos e há diversas características estatísticas presentes na amostra que não se mantiveram constantes. A autora também analisou 64 pequenas empresas que completaram a recuperação e somente $40 \%$ tiveram plano aprovado por todas as classes de credores. Para as demais, as negociações não foram bem sucedidas ou a justificativa do plano não foi convincente. Do total de insucessos, $30 \%$ tiveram falência decretada e as demais entraram em liquidação-reorganização, vendendo a empresa como um todo no mercado. Não houve decretação de cramdown. As empresas bem sucedidas na recuperação pagaram aos credores sem garantia, em média, $16 \%$ do valor total dos créditos à vista e $18 \%$ em prestações adicionais ao longo de seis anos. Na liquidação, os credores receberam, em média, $4 \%$ do valor. Nas vendas da empresa como um todo no mercado, o pagamento médio foi de 13\%. A análise indicou que nas empresas em recuperação há melhores possibilidades de pagamento aos credores sem garantia. (WHITE, Michelle J. The corporate bankruptcy decision. In: POSNER, Richard; PARISI, Francesco, Law and Economics. Cheltenham, UK: Lyme, US: Edward Elgar Publishing, Volume III, pp. 350-351; 360-361)

${ }^{79}$ Estudo do Banco Mundial realizado em 35 países indica que há correlação entre estruturas institucionais, eficiência e utilização do procedimento concursal. (CLAESSENS, Stijn; KLAPPER, L. F. Bankruptcy Around the World - Explanations of its Relative Use. Policy Research Working Paper n. 2865, July 2004. Disponível em: <http://www.worldbank.org >. Acesso em: 25.abr.2006, pp. 3-5; 25). O estudo não contempla informações sobre o Brasil, parece desconsiderar a importância das regras informais e a evolução das instituições, e enfatiza discussão superada sobre a eficiência relativa dos sistemas de Common Law e Civil
} 


\section{II.3. Mecanismo de alocação de perdas.}

O tratamento da crise requer a comparação de alternativas que instrumentalizem a escolha entre recuperação ou falência e realizem a alocação de perdas segundo critérios previamente estabelecidos. Tal mecanismo ${ }^{80}$ deve ser lei concursal capaz de identificar e classificar crises, separar as empresas eficientes das ineficientes e aplicar tratamentos distintos a cada grupo, uniformizando as decisões e estabelecendo restrições às escolhas ${ }^{81}$. Como resultado, a lei deve criar condições para recuperação da empresa eficiente (viável) e liquidação da ineficiente (inviável) ${ }^{82}$.

Mesmo em países nos quais o instituto da recuperação judicial é utilizado há mais tempo, subsistem controvérsias a respeito de sua utilidade. Douglas Baird e Robert Rasmussen entendem que as reorganizações sob o Capítulo 11 do Bankruptcy Code norte-americano desapareceram; indicam que $84 \%$ das empresas em recuperação judicial, em 2002, já haviam celebrado acordo prévio com os credores, usando o procedimento apenas para realizar a venda judicial dos ativos ${ }^{83}$. Lynn Lopucki discorda

Law (ver: SZTAJN, Rachel; GORGA, Érica. Tradições do Direito. In ZYLBERSTAJN, Decio; SZTAJN, Rachel (coord.). Direito e Economia - Análise econômica do direito e das organizações. São Paulo: Campus, 2005, pp. 137-196). Outro estudo do Banco Mundial realizado entre 1997 e 1998 no Leste da Ásia analisou 4.569 empresas de Hong Kong, Indonésia, Japão, Coréia, Malásia, Filipinas, Cingapura, Taiwan e Tailândia. Indica que apenas 106 empresas entraram com pedido de falência ou recuperação e enfatiza a importância das relações pessoais de empresários com agentes financeiros, que encorajam renegociações fora dos tribunais e o adiamento do uso de procedimentos de insolvência, com prejuízo aos credores sem garantia. (CLAESSENS, Stijn; DJANKOW, S.; KLAPPER, L. F. Resolution of corporate distress - evidence from East Asia's financial crisis. Policy Research Working Paper n. 2133, June 1999. Disponível em: $<$ http://www.worldbank.org>. Acesso em: 25.abr.2006, pp. 1-3)

${ }^{80} \mathrm{O}$ conceito de mecanismo é definido na seção II.5.2.

${ }^{81}$ Seções III.1 e III.2.

${ }^{82}$ Trata-se de eficiência alocativa das trocas, a busca do melhor resultado ao menor custo possível, isto é, o saldo de maior produtividade ou rendimento. A eficiência pode ser baseada nos critérios de Pareto ou KaldorHicks, mas, quando há informação privada detida pelos agentes, é preferível usar o segundo critério. Nicholas Mercuro e Steven Medema entendem que a economia não está no ponto ótimo de Pareto se ainda podem ocorrer mudanças que permitam ao agente melhorar sua situação sem prejudicar os demais. É condição necessária, porém insuficiente para maximização do bem-estar geral. A noção de Kaldor-Hicks baseia-se no princípio da compensação potencial, isto é, o beneficiado pela mudança pode compensar o prejudicado e permanecer melhor do que estava, ou então o prejudicado não pode compensar o beneficiado para voltar à situação anterior sem piorar sua situação. A compensação não precisa ocorrer de fato, basta ser potencial. (MERCURO, Nicholas; MEDEMA, Steven G. Economics and the law. Princeton: Princeton University Press, 1997, pp. 25-31; 37-50).

${ }^{83}$ BAIRD, Douglas G.; Rasmussen, Robert K. The end of bankruptcy. Stanford Law Review, v. 55, 2002/2003, pp. 751-790; Chapter 11 at twilight. John M. Olin Law and Economics Working Paper Series The University of Chicago Law School, Working paper n. 201, 2003. Disponível em: $<$ http://papers.ssrn.com/abstract=455960>. Acesso em: 20.02.2006. 
e mostra que, na maioria dos casos, desenvolveu-se efetivo processo de negociação entre os agentes ${ }^{84}$.

A controvérsia implica saber se existe algum credor-investidor ("acionista residual") disposto a assumir a posição do devedor, financiando a recuperação. Em outro estudo, Lopucki aponta que 48 das 78 empresas pesquisadas não possuíam credor com tais características, e que, em dez empresas, os únicos interessados eram os atuais acionistas $^{85}$. Os dados rebatem tese tradicional, segundo a qual sempre haverá credores dispostos a assumir a posição do devedor, financiando a recuperação.

Baird e Rasmussen apresentam três argumentos para concluir que as empresas não mais se utilizam da recuperação: (i) elas não possuem nenhum valor de venda, a não ser que tenham ativos com alta especificidade; (ii) as regras jurídicas permitem transferir direitos de controle sobre a empresa aos credores-investidores que fazem empréstimos à empresa, e que estes teriam informação completa e incentivos adequados para tomar a decisão; (iii) existe mercado secundário para venda da empresa, capaz de substituir as recuperações judiciais ${ }^{86}$.

Lopucki rebate os três argumentos apontando: (i) que Baird e Rasmussen não encontraram valor de venda porque analisaram o problema teoricamente, sugerindo que o valor não depende apenas da especificidade dos ativos, mas também dos relacionamentos construídos com terceiros; (ii) que a visão sobre os credoresinvestidores não faz sentido, pois significaria que a decisão está nas mãos de um

\footnotetext{
${ }^{84} \mathrm{O}$ autor aponta que, entre 1982 a 1988, vinte e nove empresas emergiram do procedimento com $44 \%$ do tamanho original, número que subiu para $77 \%$ das noventa e seis empresas que se reorganizaram entre 1991 e 1996, e $75 \%$ das dezoito empresas reorganizadas em 2001, sugerindo tendência de fortalecimento do uso da recuperação. Afirma que 53\% dos devedores preferiram submeter-se à recuperação para se valer dos incentivos legais, mesmo quando há acordos prévios. Apenas 20\% das 174 empresas pretendiam liquidar os ativos, e apenas $4 \%$ entraram com pedidos de homologação de plano de recuperação que simplesmente reproduzia acordo prévio celebrado com credores fora do procedimento concursal. (LOPUCKI, Lynn. The nature of the bankrupt firm: a reply to Baird and Rasmussen's 'The End of Bankruptcy'. Stanford Law Review, v. 56, 2003/2004, pp. 645-672)

${ }^{85}$ Lynn Lopucki define acionista residual como: “(...) o investidor que irá obter o ganho financeiro marginal ou sofrer a perda financeira marginal das atividades da empresa”. Acrescenta que “(...) Se esse tipo de investidor existe, é a pessoa perfeita para controlar a empresa. Seus interesses e os da firma em crise são idênticos". (LOPUCKI, Lynn. The nature of the bankrupt firm: a reply to Baird and Rasmussen's 'The End of Bankruptcy'. Stanford Law Review, v. 56, 2003/2004, p. 18)

${ }^{86}$ BAIRD, Douglas G.; RASMUSSEN, Robert K. The end of bankruptcy, Stanford Law Review, v. 55, 2002/2003, pp. 751-790.
} 
investidor que não seria reembolsado; além disso, a empresa em crise tem múltiplas e complexas classes de credores, o que não corresponde à idéia do credor residual; (iii) que a recuperação é necessária mesmo que as empresas são vendidas no mercado secundário, porque se desenvolve um complexo processo de negociação antes da venda.

Lopucki sugere que a maioria dos credores prefere a recuperação e que as empresas entram em liquidação apenas quando os administradores concluem que elas não sobreviverão. Entende que a comparação entre o valor de liquidação e o valor de venda não é o único critério de decisão, argumentando que as empresas viáveis tentam evitar a liquidação para impedir a diluição do valor e a transferência de renda dos acionistas para os credores. Entende que o mesmo se aplica a outros interessados (trabalhadores, gerentes, fornecedores, clientes), com impactos na perda de empregos e cancelamento de contratos de fornecimento. Lopucki conclui que as diferenças de entendimento derivam do fato de que Baird e Rasmussen conceituam a empresa como entidade legal, enquanto ele a entende como organização composta por pessoas e $\operatorname{ativos}^{87}$.

A discussão a respeito da utilidade da recuperação judicial de empresas subordina-se à compreensão de que as opções legais (recuperação ou falência) criam incentivos à escolha. Incentivo, definido como o prêmio ou punição, é usado para fazer com que os agentes econômicos se comportem de acordo com as expectativas de seu idealizador. É a forma pela qual terceiros induzem comportamentos de outros, mediante oferecimento de ganhos ou imposição de perdas decorrentes da prática de certos atos.

Norberto Bobbio utiliza os conceitos de "encorajamento" e "desencorajamento" para explicar a noção de incentivo. O autor entende ser técnica de organização social desempenhada pela "função promocional" do direito, cuja finalidade é promover e estimular condutas desejadas, e não somente reprimir as indesejadas. Conceitua "desencorajamento" como a operação na qual um agente influencia o comportamento não desejado do outro, atribuindo-lhe conseqüências desagradáveis, e define

\footnotetext{
${ }^{87}$ LOPUCKI, Lynn. The nature of the bankrupt firm: a reply to Baird and Rasmussen's 'The End of
} Bankruptcy'. Stanford Law Review, v. 56, 2003/2004, pp. 645-672. 
"encorajamento" como a operação que direciona o comportamento desejado do outro, atribuindo-lhe conseqüências prazerosas ${ }^{88}$. $\mathrm{O}$ autor ainda distingue incentivo de prêmio, em função do momento de aplicação. O primeiro é medida que acompanha a atividade em formação, servindo para facilitar a execução. O segundo visa a oferecer satisfação àqueles que já realizaram determinada atividade: é, portanto, atribuído ao agente depois que a atividade foi executada ${ }^{89}$.

Um incentivo produz uma situação de equilíbrio quando não há mais interesse em modificar as condições estabelecidas. A estrutura de incentivos deve ser organizada de forma a compelir o agente a gerar o maior benefício social possível e a não agir de forma a causar prejuízos aos demais agentes e à coletividade. Como o agente responde a incentivos, as regras legais podem ser entendidas como "preços" a pagar por determinado comportamento. Os indivíduos comparam benefícios e custos da atividade (legal ou ilegal), assumindo os riscos da decisão.

A função de qualquer lei que pretenda maximizar o bem-estar geral é alterar a estrutura de incentivos para induzir comportamentos adequados dos agentes ${ }^{90,91}$. Se a lei concursal não for desenhada corretamente, os incentivos podem produzir resultados indesejados, pois devedor e credores racionais optam pela alternativa que melhor atende aos interesses individuais, muitas vezes contrários ao bem-estar geral ${ }^{92}$. Neste caso, podem ocorrer dois tipos de erro: recuperar empresas ineficientes (erro do tipo I) ou submeter à falência as eficientes (erro do tipo II).

A ciência estatística estabelece a noção do "erro" e apresenta sua tipologia. Ao formular hipóteses, um dos objetivos do cientista é verificar se a nova idéia é melhor ou pior do que idéia original ("hipótese normal”), isto é, o estado esperado para a situação.

\footnotetext{
${ }^{88}$ BOBBIO, Norberto. Da estrutura à função: novos estudos de teoria do direito. São Paulo: Manole, 2007, pp. 14-16.

${ }^{89}$ Ibid, pp.72, 77.

${ }^{90}$ MERCURO, Nicholas; MEDEMA, Steven G. Economics and the law. Princeton: Princeton University Press, 1997, p. 25.

${ }^{91}$ Ver também: SZTAJN, Rachel. Law and economics. Revista de Direito Mercantil, Industrial, Econômico e Financeiro, Ano XLIV, n. 137, pp. 227-232, Jan./Mar. 2005; NORTH, Douglass C. Institutions, institutional change and economic performance. New York: Cambridge University Press, 2002, pp. 47-48; 50-53.

92 WHITE, Michelle J. The corporate bankruptcy decision. In: POSNER, Richard; PARISI, Francesco, Law and Economics. Cheltenham, UK: Lyme, US: Edward Elgar Publishing, Volume III, pp. 349-350.
} 
Ele precisa garantir que não cometerá erros na verificação: rejeitar hipótese verdadeira ou aceitar hipótese falsa. O problema é tratado pelo teste de hipóteses, no qual são formuladas proposições e verificadas as respostas. $\mathrm{O}$ teste prevê duas possibilidades de tomar decisões erradas. O erro do tipo I ocorre quando a hipótese verdadeira é rejeitada pelo cientista. Por exemplo, se a empresa é ineficiente, a solução deve ser a falência; como o cientista rejeita a hipótese, supondo que a empresa é eficiente, escolhe a recuperação e acaba por salvar empresa que deveria ser liquidada. $\mathrm{O}$ erro do tipo II ocorre quando a hipótese falsa não é rejeitada. Por exemplo, a hipótese formulada ("a empresa é ineficiente") é falsa, porque a empresa é eficiente, porém o cientista opta pela falência, escolhendo solução errada ${ }^{93}$.

O erro do tipo I é o "falso positivo": por exemplo, imaginar ter produzido o medicamento para a cura do câncer, quando na verdade o remédio não cura a doença. No primeiro momento, o cientista acredita ter encontrado a cura e prescreve o remédio aos pacientes. Ele descobrirá que a solução é inócua quando os pacientes começarem a morrer de câncer. O erro do tipo II é o "falso negativo": o cientista produziu, de fato, medicamento que cura o câncer, mas não foi capaz de perceber a descoberta. Ele acaba por descartar o uso do medicamento em pacientes, que morrerão. Qual o erro mais grave: matar o paciente por prescrever medicamento inócuo ou deixá-lo morrer por não ter prescrito o remédio salvador?

Luca Enriques, ao tratar o conflito de interesses nas sociedades por ações, utiliza os dois conceitos. Para ele, o "falso negativo" é caso de abuso que permanece impunível, porque não foi submetido ao crivo do judiciário ou foi impossível provar o cometimento do abuso. O "falso positivo" é o mero conflito potencial de interesses, situação na qual não há abuso efetivo e o administrador agiu no melhor interesse da sociedade, mas o juiz entende ter provado o prejuízo ${ }^{94}$. Qual o pior erro: deixar de punir o administrador que age em real conflito de interesses ou punir o administrador que, de boa-fé, age no interesse da sociedade?

\footnotetext{
${ }^{93}$ Existe também o erro do tipo III, não tratado no modelo proposto: rejeitar hipótese falsa por motivos incorretos. (SANDRONI, Paulo. Dicionário de Economia. $3^{a}$ ed., São Paulo: Best Seller, 1994, p. 119; HOEL, Paul G. Estatística elementar. São Paulo: Atlas, 1977, pp. 201-202).

${ }^{94}$ ENRIQUES, Luca. Il conflitto d'interessi nella gestioni delle società per azioni: spunti teorici e profili comparatistici in vista della riforma del diritto societario. Rivista delle Società, Ano 45 / 2000, Mai./Ago. 2000, fascículo $3^{\circ}-4^{\circ}$, p. 512.
} 
Os exemplos demonstram que a diminuição da probabilidade de ocorrência de um tipo de erro acaba por aumentar o aparecimento do outro. Por isso, o experimento científico deve ser planejado de forma a restringir a ocorrência de ambos. Como os erros são inevitáveis, a solução depende de se definir qual dos dois tipos é menos desejável, procurando ajustar o experimento para minimizá-lo. Para o problema da crise da empresa, antes da elaboração da nova lei, o legislador, com base em dados empíricos coletados, deveria decidir se é pior para a comunidade levar à falência as empresas eficientes ou recuperar empresas ineficientes. Tal decisão deve ser tomada antes mesmo de se determinar como será definida e medida a eficiência. Não se tem notícia de que tal estudo tenha sido realizado para orientar a elaboração da LREF.

O quadro abaixo apresenta duas situações (empresa eficiente ou ineficiente) e as escolhas possíveis (recuperação ou falência). As "hipóteses normais", nas quais não há erro, ocorrem quando a empresa é eficiente e a solução escolhida é a recuperação, e também quando a empresa é ineficiente e opta-se pela falência. Há erro do tipo I quando a empresa é ineficiente e escolhe-se a recuperação. Há erro do tipo II quando a empresa é eficiente e a solução escolhida é a falência.

\begin{tabular}{|l|l|l|}
\hline Hipótese & Solução escolhida & Verificação da decisão \\
\hline \multirow{2}{*}{ Empresa é ineficiente } & Recuperação & Erro do tipo I \\
\cline { 2 - 3 } & Falência & Hipótese normal (não há erro) \\
\hline \multirow{2}{*}{ Empresa é eficiente } & Recuperação & Hipótese normal (não há erro) \\
\cline { 2 - 3 } & Falência & Erro do tipo II \\
\hline
\end{tabular}

Os erros nas escolhas implicam em custos de transação de duas espécies: (i) custos diretos, associados ao procedimento concursal: desenvolvimento das atividades previstas em lei, ações e execuções contra o devedor, custas judiciais; (ii) custos indiretos, relativos à atividade empresarial: inoperância da empresa durante o procedimento, declínio de faturamento, perda de clientes, desvalorização de ativos. Os custos diretos são de mais fácil mensuração que os indiretos, mas os segundos tendem a ser maiores que os primeiros ${ }^{95,96,97}$.

\footnotetext{
${ }^{95}$ Nicholas Mercuro e Steven Medema indicam que os custos de transação existem em múltiplos níveis, associados à criação, manutenção ou modificação das instituições. No nível individual, consistem em custos de contratação entre as partes. No nível coletivo, envolvem o processo de negociação através do qual a
} 
Os custos incorridos com o erro do tipo I são os custos da permanência da empresa ineficiente por mais tempo no mercado, somados aos custos de não realocação dos ativos para empreendimentos mais produtivos. O erro do tipo II implica em custos de liquidação da empresa eficiente, somados à perda incorrida pela realocação de ativos para negócios de produtividade inferior ${ }^{98}$.

Ao introduzir o instituto da recuperação de empresas, a LREF visava a estabelecer critérios para tentar resolver o problema da escolha de alternativas, mas acabou por permitir a ocorrência dos dois tipos de erro ${ }^{99}{ }^{100}$. A LREF não é “compatível

estrutura institucional é estabelecida e mantida. (MERCURO, Nicholas; MEDEMA, Steven G. Economics and the law. Princeton: Princeton University Press, 1997, p. 131). O conceito econômico de transação é distinto do jurídico, que indica a capacidade de transigir sobre direitos patrimoniais, terminando litígios mediante concessões mútuas (Código Civil, arts. 840 e 841).

${ }^{96}$ Os custos de transação são positivos e a atribuição inicial de direitos e o poder de negociação das partes afetam os resultados. Se não há custos, o poder de negociação não afeta o resultado, que será sempre eficiente, não importando a atribuição inicial de direitos. (COASE, Ronald. The problem of social cost. In The firm, the market, and the law, Chicago: University of Chicago Press, 1990, p. 104). Segundo Paulo Sandroni, o teorema de Coase "(...) assegura que as externalidades não provocam a alocação imperfeita de recursos desde que os custos de transação (para a elaboração de contratos e negociações de acordos) sejam nulos e os direitos de propriedade bem definidos e respeitados. Nesse caso, as partes, o produtor e o consumidor da externalidade, teriam um incentivo de mercado para negociar um acordo em benefício mútuo, de tal forma que a externalidade fosse 'internalizada'. O teorema estabelece que o resultado deste processo de troca seria o mesmo, tanto se fosse o produtor ou o consumidor de externalidade quem possuísse o poder de veto ou o direito de propriedade de usar ou não o recurso." (SANDRONI, Paulo. Dicionário de Economia. $3^{\text {a }}$ ed., São Paulo: Best Seller, 1994, p. 347)

${ }^{97}$ Em relação à recuperação da empresa, Francesco Cabrillo e Ben Depoorter classificam os custos de transação em custos de bens de capital, custos relativos à ociosidade de ativos e custos de litígio. Em ambiente de informação perfeita, os primeiros costumam ser menores quando a empresa é vendida em bloco, mas quando a informação é imperfeita nem sempre haverá investidores interessados em adquirir os bens. A ociosidade de ativos surge quando a empresa fica inoperante ou há obsolescência dos ativos, minimizado quando a empresa continua em operação durante o procedimento concursal. Os custos de litígio, por sua vez, são assumidos pelo credor para aumentar a chance de obter decisão favorável em juízo, mas, no procedimento concursal, o litígio costuma diminuir o valor total dos ativos. (CABRILLO, Francesco; DEPOORTER, Ben W. F. Bankruptcy proceedings. Encyclopedia of Law and Economics. Disponível em: $<$ http://encyclo.findlaw.com/7800.html >. Acesso em: 11.nov.2005)

${ }^{98}$ WHITE, Michelle J. Corporate bankruptcy as a filtering device: Chapter 11 reorganizations and out-ofcourt debt restructurings. Journal of Law, Economics and Organization, n. 10, pp. 268-295, 1984.

${ }^{99}$ Michelle White afirma que, sob certas condições, o sistema concursal, ao invés de possibilitar alcançar eficiência de longo prazo, pode apenas adiar a alocação ideal de recursos. (WHITE, Michelle J. The corporate bankruptcy decision. In: POSNER, Richard; PARISI, Francesco, Law and Economics. Cheltenham, UK: Lyme, US: Edward Elgar Publishing, Volume III, p.350)

${ }^{100}$ Francesco Cabrillo e Ben Depoorter afirmam que o procedimento de recuperação é demorado, custoso e normalmente reduz o valor dos ativos. Os autores indicam que os argumentos usados pelos estudiosos não explicam porque empresas com baixa probabilidade de recuperação são reorganizadas e empresas com alta probabilidade de recuperação são liquidadas. (CABRILLO, Francesco; DEPOORTER, Ben W. F. Bankruptcy proceedings. Encyclopedia of Law and Economics. Disponível em: $<$ http://encyclo.findlaw.com/7800.html>. Acesso em 11.nov.2005, pp. 276-277) 
em termos de incentivos" ${ }^{101}$, porque não oferece benefícios para a revelação de informação assimétrica pelos agentes. Como consequiência, há razoável probabilidade de ocorrência de erros de avaliação, em especial o erro do tipo I, porque os dispositivos legais permitem a recuperação da empresa ineficiente.

O principal incentivo que condiciona o comportamento dos agentes é o valor total obtido ou perdido com a negociação sobre os créditos devidos, apurado ao final do procedimento concursal ${ }^{102}$. A LREF não é capaz de realizar a distribuição equitativa de riscos entre os jogadores e também não consegue compatibilizar os interesses em conflito, pois estes são condicionados pelos direitos de propriedade ${ }^{103}$, informações privadas detidas pelas partes, poder de negociação, proibições legais, modelos mentais e limitações cognitivas dos agentes ${ }^{104}$.

\section{II.4. Racionalidade e oportunismo.}

O modelo parte de premissa típica da teoria dos jogos, que supõe ser racional o comportamento dos agentes. É preciso então definir o que se entende por racionalidade.

Racionalidade significa coerência entre os fins desejados e os meios empregados para atingi-los. O indivíduo altruísta pode ser tão racional quanto o egoísta, dependendo dos objetivos. A racionalidade não se refere aos fins em si mesmos, mas aos meios empregados para alcançá-los. A avaliação dos objetivos dos jogadores é definida pela moral e pela ética, não pela teoria dos jogos. O objetivo egoísta ou altruísta do jogador depende da natureza do processo interativo, não tendo relação com o conceito de racionalidade.

Agente racional é aquele que: (i) aplica a lógica das premissas para obter

${ }^{101}$ Conceito de compatibilidade de incentivos na seção II.5.2.

$102 \mathrm{O}$ valor da empresa afeta diretamente o interesse em negociar (ver seção III.1).

${ }^{103}$ Conceito apresentado na seção III.1.

${ }^{104}$ Nosso estudo não aborda a influência dos componentes psicológicos do processo decisório. Francesco Parisi e Vernon Smith afirmam que a ação humana é resultado de decisões individuais afetadas por restrições econômicas, preferências pessoais, conhecimentos, habilidades e dons. (PARISI, Francesco; SMITH, Vernon. The law and economics of irrational behavior: an introduction. George Mason University Law and Economics Research Paper Series. Disponível em: <http://ssrn.com/abstract_id=586649>. Acesso em: 15.abr.2006, p. 3). 
conclusões; (ii) utiliza premissas justificadas, isto é, adequadas aos meios empregados; (iii) usa evidências empíricas de forma imparcial para julgar afirmações sobre fatos ${ }^{105}$.

O comportamento dos agentes é orientado pela noção de racionalidade limitada e oportunismo, não pela racionalidade plena. A racionalidade limitada reduz a percepção cognitiva do agente nas interações com os outros. Trata-se de racionalidade que é pretendida, porém encontra-se limitada por diversos fatores. O oportunismo, por sua vez, orienta a busca do interesse próprio, inclusive com uso de expedientes de distorção ou sonegação de informações, esforços calculados para enganar, dissimular ou confundir o outro ${ }^{106}$.

A racionalidade plena decorre da noção de utilidade: o nível de satisfação que a pessoa tem ao consumir determinado bem ou exercer certa atividade ${ }^{107}$. Pressupõe a existência de informação completa e de indivíduos que fazem escolhas de forma eficiente a partir de um conjunto de preferências. Os indivíduos escolhem a alternativa que maximiza a utilidade pessoal e as empresas optam pela que maximiza lucros. A noção de racionalidade, ou busca pelo interesse próprio, contrasta com a de razoabilidade utilizada pelo direito, demonstrando que o comportamento racional pode entrar em conflito com normas sociais vigentes ${ }^{108}$.

Como o devedor e os credores orientam a ação de acordo com parâmetros de racionalidade limitada e oportunismo, buscam maximizar resultados usando os meios de que dispõem, porém limitados pelas informações existentes e dependentes das decisões tomadas pelos outros agentes. Eles agem em ambiente de incerteza.

O Princípio da Incerteza, ou da Indeterminação, indica que não é possível conhecer toda a informação a respeito de um objeto "em um determinado instante de tempo" ${ }^{109}$. A incerteza existe quando, a partir de determinado conjunto de ações, podese chegar a vários resultados possíveis, porque as probabilidades esperadas para os

\footnotetext{
${ }^{105}$ FIANI, Ronaldo. Teoria dos jogos. $2^{\text {a }}$ ed., São Paulo: Campus, 2006, pp. 21-22.

${ }^{106}$ WILLIAMSON, Oliver. The economic institutions of capitalism. New York: Free Press, 1987, pp. 44-49.

${ }^{107}$ PINDYCK, Robert S.; RUBINFELD, Daniel L. Microeconomia. São Paulo: Makron Books, 1994, p. 106.

${ }^{108}$ MERCURO, Nicholas; MEDEMA, Steven G. Economics and the law. Princeton: Princeton University Press, 1997, p. 57.

${ }^{109}$ HEIZENBERG, Werner. Física e filosofia. $4^{\text {a }}$ ed., Brasília: UNB, 1999, pp.31-32.
} 
resultados não são conhecidas. Caso estas sejam de conhecimento do agente, trata-se de "risco" e não de "incerteza" ${ }^{110}$. Como devedor e credores agem em ambiente de incerteza, muitas vezes não conhecem o risco decorrente das decisões que tomam.

Os agentes comportam-se de acordo com a "motivação" e a "habilidade em decifrar o ambiente". Segundo Douglass North, estas são características que tornam a escolha humana mais complexa do que as previsões feitas pela teoria da escolha racional. A "motivação" indica o conjunto de condições que compele o indivíduo a agir, influenciado por fatores econômicos e altruísticos que podem ser inconsistentes com premissas racionais de maximização de bem-estar. A "habilidade em decifrar o ambiente" é a capacidade do indivíduo em entender o contexto situacional em que se encontra, dadas as informações disponíveis ${ }^{111}$.

A "motivação" do agente é influenciada pela reputação, confiança e aspectos altruísticos que podem ser decisivos em certas situações. A "habilidade em decifrar o ambiente" justifica a existência de instituições que estruturam as trocas econômicas e reduzem incertezas. O processamento incompleto e subjetivo da informação desempenha papel relevante no processo decisório, pois há lacunas entre a capacidade do agente para decifrar problemas e a dificuldade em determinar preferências. Quanto maior a lacuna, maior a necessidade de padronização de respostas para lidar com as incertezas que se originam da informação incompleta, da complexidade dos problemas e da capacidade limitada dos indivíduos em resolvê-los. Regras e procedimentos existem para simplificar o processo, limitando o conjunto de escolhas possíveis. Estas podem, ou não, coincidir com a maximização de bem-estar geral ${ }^{112}$.

No procedimento concursal, a "motivação" do agente depende da reputação das partes, valor da empresa, duração do procedimento concursal, condições do mercado. A "habilidade em decifrar o ambiente" implica na capacidade de revelar ou reter informações relevantes, monitorar e controlar o andamento do procedimento concursal,

\footnotetext{
${ }^{110}$ SANDRONI, Paulo. Dicionário de Economia. $3^{\mathrm{a}}$ ed., São Paulo: Best Seller, 1994, p.168.

111 NORTH, Douglass C. Institutions, institutional change and economic performance. New York: Cambridge University Press, 2002, p. 17.

112 NORTH, Douglass C. Institutions, institutional change and economic performance. New York: Cambridge University Press, 2002, pp. 20-25.
} 
influenciar outros agentes e obter garantias para os créditos.

O procedimento de insolvência empresarial é composto por informações assimétricas, imperfeitas e incompletas ${ }^{113}$, diferentes níveis de poder de negociação, custos positivos de transação e expectativa de que os agentes adotarão comportamentos oportunistas na defesa dos interesses. Além disso, certas classes de credores possuem maior capacidade de obtenção de informações e proteção contra riscos, gerando comportamentos distintos daquelas com menor capacidade de defender os próprios interesses ${ }^{114}$. Devedores e credores têm interesses opostos e a sonegação de informações aumenta o poder de negociação, ampliando os ganhos. Para ser compatível em termos de incentivos, a lei deve induzir o agente que detém informação privada a revelá-la, o que nem sempre ocorre segundo as regras jurídicas vigentes.

Quando existe informação assimétrica, é improvável salvar todas as empresas eficientes e liquidar todas as ineficientes, podendo haver erros que resultam em externalidades negativas ${ }^{115}$, gerando ineficiências de mercado e imposição de custos àquele que não participa das decisões.

\section{II.5. Teorias utilizadas.}

\section{II.5.1. Teoria dos jogos.}

A teoria dos jogos é tema de fronteira em microeconomia que vem ganhando importância crescente na formulação de raciocínios econômicos e jurídicos. Apesar da recente formalização, seus pressupostos teóricos remontam à antigüidade.

Robert Aumann e Michael Maschler afirmam que o Talmud babilônico continha prescrições que apenas recentemente foram reconhecidas como antecipação de premissas de jogos não-cooperativos. Por exemplo, a solução, que parece contraditória,

\footnotetext{
${ }^{113}$ Conceitos na seção II.5.1.

${ }^{114}$ A respeito do último ponto: SALOMÃO FILHO, Calixto. O novo direito societário. $2^{\mathrm{a}}$ ed., São Paulo: Malheiros, pp. 117-119.

${ }^{115}$ A externalidade pode ser negativa ou positiva. A primeira ocorre quando o agente impõe custos a outro, que não participa dos benefícios. A segunda, quando o beneficiado não participa dos custos. As externalidades, por não estarem refletidas em preços de mercado, podem gerar ineficiências. (PINDYCK, Robert S.; RUBINFELD, Daniel L. Microeconomia. São Paulo: Makron Books, 1994, p. 844)
} 
para o contrato de casamento especifica, em caso da morte de homem com três esposas, que a primeira receba 100, a segunda, 200 e a terceira, 300. O Talmud recomenda que, quando o homem morre e deixa patrimônio de apenas 100, a divisão de bens deve ser igual para as três mulheres. Quando deixa patrimônio de 300, a divisão deve ser proporcional ao especificado no contrato, isto é, a primeira esposa recebe 50, a segunda recebe 100 e a terceira, 150. Se o valor for de 200, a recomendação de divisão é desproporcional: a primeira esposa recebe 50 e a segunda e a terceira esposas recebem, cada uma, 75. Os autores demonstram que cada solução corresponde a um jogo nos termos definidos pela moderna teoria dos jogos. Para o problema da insolvência, o Talmud traz solução idêntica à especificada para o problema do casamento ${ }^{116}$.

A teoria dos jogos pretende especificar maneiras para lidar com cooperação e conflito e estudar decisões tomadas em situações nas quais os jogadores interagem. Estuda a escolha de estratégias quando os custos e benefícios de cada opção dependem de escolhas feitas pelos adversários. Pressupõe a aplicação de regras lógicas ao processo de tomada de decisão em situações como negociações, relações internacionais, antitruste, guerras, licitações, leilões.

A teoria utiliza os seguintes elementos básicos: jogos, jogadores, jogadas, estratégias e resultados. Jogo é toda situação na qual há dois ou mais jogadores e as decisões de um interferem nas do outro. Jogador é aquele que participa do jogo com o objetivo de obter determinado resultado. Jogada é a forma como o jogo progride de um estágio a outro. Resultado é o ganho ou perda total obtido ao final do jogo ${ }^{117}{ }^{118}$. Estratégias são ações que o jogador pode adotar nos momentos em que deve jogar ${ }^{119}$. As estratégias selecionadas pelos jogadores dependem dos "conjuntos de informação" disponíveis, isto é, dos estágios do jogo que podem ser alcançados ${ }^{120}$.

\footnotetext{
${ }^{116}$ AUMANN, Robert J.; MASCHLER, Michael. Game theoretic analysis of a bankruptcy problem from the Talmud. Journal of Economic Theory, n. 36, 1985, pp. 195-213.

${ }^{117}$ DAVIS, Morton D. Teoria dos jogos - uma introdução não técnica. Tradução: Leonidas Hezenberg. São Paulo: Cultrix, 1973, pp. 15-18.

${ }^{118}$ Há outros elementos, como a sinalização e a seleção, que podem tomar a forma de ameaças, promessas e compromissos assumidos pelos jogadores quando negociam, podendo ou não ser levados em consideração pela outra parte (credibilidade da sinalização). (PINDYCK, Robert S.; RUBINFELD, Daniel L. Microeconomia. São Paulo: Makron Books, 1994, pp. 632; 651)

${ }^{119}$ FIANI, Ronaldo. Teoria dos jogos. $2^{a}$ ed., São Paulo: Campus, 2006, p. 56.

${ }^{120} \mathrm{Ibid}$, p. 59.
} 
Os jogos podem ter a participação de duas ou mais pessoas. Nos jogos com duas pessoas as decisões são tomadas pelo jogador com base no comportamento do outro. Quando há mais de duas pessoas as decisões são mais complexas, podendo haver formação de coalizões e estabelecimento de acordos para transformar o jogo com vários jogadores em jogo de duas pessoas, no qual os resultados podem ser mais facilmente mensurados e avaliados.

Os jogos são também classificados em função dos resultados, podendo ser de soma zero e soma não-zero. Nos primeiros, os ganhos para um jogador são perdas para o outro, isto é, a soma dos resultados é nula, enquanto nos segundos podem existir ganhos sem as correspondentes perdas ${ }^{121}$.

Os jogos podem ser seqüenciais ou simultâneos, representados na forma normal ou extensiva. O jogo é de forma normal quando toda a seqüência de decisões a serem tomadas pode ser resumida na escolha de uma estratégia. Os jogos, em geral, são disputados na forma extensiva: as decisões são tomadas uma após a outra ${ }^{122}$. Os jogos seqüenciais são representados em árvores de decisão (forma estendida), e a forma estratégia (forma normal ou matricial) é usada para representar jogos simultâneos. Nestes, o jogador toma a decisão no mesmo momento que os demais jogadores. No jogo seqüencial, ao contrário, as escolhas são realizadas em uma ordem predeterminada. A árvore é formada por ramos e nós. Cada nó representa uma etapa do jogo na qual o jogador deve tomar a decisão. Ramo, por sua vez, representa uma possibilidade de escolha a partir de determinado nó, isto é, o conjunto de possíveis ações para o jogador que se encontra naquele nó ${ }^{123}$.

Há jogos simétricos e assimétricos. Nos primeiros a matriz de resultados tem o mesmo aspecto para todos os jogadores, o que não ocorre nos segundos ${ }^{124}$.

\footnotetext{
${ }^{121}$ DAVIS, Morton D. Teoria dos jogos - uma introdução não técnica. Tradução: Leonidas Hezenberg. São Paulo: Cultrix, 1973, pp. 21-22; 25-30; 79-80; 146-148.

122 Ibid, p. 28.

${ }^{123}$ FIANI, Ronaldo. Teoria dos jogos. $2^{\mathrm{a}}$ ed., São Paulo: Campus, 2006, pp. 46-56.

${ }^{124}$ DAVIS, Morton D. Teoria dos jogos - uma introdução não técnica. Tradução: Leonidas Hezenberg. São Paulo: Cultrix, 1973, p. 89.
} 
Os jogos podem ser de informação perfeita e completa, ou imperfeita e incompleta. Há informação imperfeita (incompleta) quando, ao realizar a escolha, o jogador não conhece a escolha do adversário ${ }^{125}$. Ronaldo Fiani define jogo de informação completa como aquele no qual todos os jogadores conhecem as preferências de todos os demais. Segundo o autor, o problema deste tipo de jogo é estabelecer acordos ou contratos que alinhem os incentivos para todos ${ }^{126,}{ }^{127}$.

Há jogos cooperativos e não-cooperativos. A cooperação existe quando os jogadores podem negociar entre si, planejando estratégias em conjunto. O jogo é nãocooperativo quando tal negociação não é possível ${ }^{128}$. Ronaldo Fiani define jogo nãocooperativo como aquele no qual os jogadores não podem estabelecer compromissos com garantia de cumprimento ${ }^{129}$. A cooperação pode ocorrer antes do jogo, por meio da coordenação de estratégias, ou durante o jogo, por meio de "pagamentos colaterais" ${ }^{130}$, acordos entre os jogadores para dividir ganhos e induzir a cooperação. Se houver formação de coalizão entre jogadores, há jogo cooperativo entre os membros que a compõem e jogo não-cooperativo entre a coalizão e os demais jogadores ${ }^{131}$.

Os jogos podem produzir soluções de equilíbrio, que são resultados esperados para o jogo. As soluções com erros não são equilíbrios, pois são obtidas pelos jogadores com o uso de informações falsas, violando as regras estabelecidas.

Jogo clássico é o “dilema do prisioneiro”. É definido como a situação na qual os jogadores escolhem a solução não-cooperativa que traz piores resultados para todos, devido à incapacidade de cooperarem para escolher a melhor solução. O dilema é

\footnotetext{
${ }^{125}$ Segundo Morton Davis, para que esses jogos funcionem corretamente, os jogadores têm que ser racionais. (DAVIS, Morton D. Teoria dos jogos - uma introdução não técnica. Tradução: Leonidas Hezenberg. São Paulo: Cultrix, 1973, pp. 30-31)

${ }^{126}$ FIANI, Ronaldo. Teoria dos jogos. $2^{\mathrm{a}}$ ed., São Paulo: Campus, 2006, pp. 370-371.

${ }^{127}$ Robert Pindyck e Daniel Rubinfeld entendem que a tomada de decisão é baseada nas características da informação disponível para os agentes. Quanto maior a quantidade e qualidade destas, mais bem informada será a decisão. $\mathrm{O}$ valor da informação completa corresponde à diferença entre o valor esperado da escolha, quando a informação é completa, e o valor esperado quando a informação é incompleta. (PINDYCK, Robert S.; RUBINFELD, Daniel L. Microeconomia. São Paulo: Makron Books, 1994, p. 198)

${ }_{128}$ PINDYCK, Robert S.; RUBINFELD, Daniel L. Microeconomia. São Paulo: Makron Books, 1994, p. 609.

${ }^{129}$ FIANI, Ronaldo. Teoria dos jogos. $2^{\mathrm{a}}$ ed., São Paulo: Campus, 2006, pp. 111.

${ }^{130}$ A teoria dos jogos utiliza a expressão "side payments".

${ }^{131}$ DAVIS, Morton D. Teoria dos jogos - uma introdução não técnica. Tradução: Leonidas Hezenberg. São Paulo: Cultrix, 1973, pp. 90-104.
} 
exemplificado da seguinte forma: dois criminosos são capturados, mas as evidências do crime são suficientes para condená-los a, no máximo, dois anos de prisão. O jogo parte da premissa de que o promotor de justiça pode utilizar a estratégia de oferecer o benefício da delação premiada, negociando a redução da pena do suspeito em troca da delação do comparsa. Se o promotor conseguir a confissão de um deles, terá mais informações para condenar o outro a pena maior, de dez anos. O promotor coloca os dois suspeitos em celas separadas e não permite que os dois se comuniquem, propondo a cada um que confesse, delatando o outro em troca de redução de metade da pena. Se ambos confessam, cada um recebe cinco anos de prisão. Se não confessam, devido à ausência de provas, o promotor só conseguirá obter dois anos de condenação para cada suspeito. Se um confessa e o outro não, o delator consegue a redução da pena, recebendo apenas um ano de condenação, ao passo que o comparsa recebe dez. Os criminosos não conseguem se comunicar para combinar o que dirão ao promotor. $\mathrm{O}$ dilema do prisioneiro, na forma matricial, é:

\begin{tabular}{|l|l|l|}
\cline { 2 - 3 } \multicolumn{1}{c|}{} & \multicolumn{2}{c|}{ Prisioneiro B } \\
\hline Prisioneiro A & Confessa & Não confessa \\
\hline Confessa & $(5,5)$ & $(1,10)$ \\
\hline Não confessa & $(10,1)$ & $(2,2)^{132}$ \\
\hline
\end{tabular}

Qual a melhor decisão para cada prisioneiro? O prisioneiro A pode ou não confessar. Se o faz, recebe cinco anos de prisão se o outro também confessar, ou um ano se o outro não confessar. Se o prisioneiro A não confessar, recebe dois anos de condenação. O prisioneiro A raciocina que se B confessar e ele ficar calado, receberá dez anos de condenação e o comparsa será condenado em apenas um ano. Se A confessar, recebe cinco anos se B confessar, ou um ano se B não confessar. Ambas as opções são melhores do que a pena máxima de dez anos, recebida se permanecer calado e o outro confessar. As escolhas do prisioneiro A dependem do que o prisioneiro B decidir.

A melhor solução para ambos é não confessar, pois ambos receberiam pena de dois anos. Como eles não conseguem se comunicar, a estratégia que cada um escolherá, individualmente, é confessar, delatando o outro e sofrendo, cada um, condenação em

\footnotetext{
${ }^{132}$ Os números entre parênteses indicam, respectivamente, os anos de prisão para os prisioneiros A e B.
} 
cinco anos. Este é o equilíbrio de Nash para o jogo, a melhor estratégia que o jogador pode adotar, consideradas as opções do outro jogador ${ }^{133}$. A estratégia ideal é que ambos não confessem, mas os prisioneiros não a escolhem, porque tomam a decisão em separado. A solução para o jogo é, portanto, que ambos irão confessar porque não conseguem se comunicar para combinar a resposta que darão ao promotor de justiça.

O leitor pode argumentar que na vida real os criminosos presos jamais confessam, delatando o líder. As razões, entretanto, são as mesmas descritas acima. Explicado em termos de teoria dos jogos, o líder do bando altera os resultados do jogo para o comparsa preso, indicando, por exemplo, que sua família será assassinada se ele delatar os comparsas. A pena imposta pelo líder é maior do que receber um, dois, cinco ou dez anos de prisão, em caso de condenação pelo promotor de justiça. Por essa razão, o prisioneiro, que responde a incentivos, permanece calado e não delata os comparsas.

Herbert Gintis explica que a crise da empresa pode ser definida como um dilema do prisioneiro: "Um devedor tem dívidas de $\$ 15.000$ com cada um de seus dois credores, mas ele só possui \$25.000. Se decide entrar em default e não pagar as dívidas gastará \$15.000, relativos aos custos de litigar com os credores, situação na qual cada credor receberá apenas $\$ 5.000$. O devedor e seu advogado escrevem a seguinte carta, que enviam aos credores: 'Eu, abaixo assinado, ofereço $\$ 5.001$ a cada um de vocês, meus credores, se ambos concordarem em cancelar a dívida integralmente. Se qualquer um de vocês não aceitar a oferta eu irei me declarar falido'." Gintis conclui que a melhor estratégia para cada credor é aceitar a oferta, permitindo ao devedor saldar a dívida e reter a quantia de $\$ 14.998$. Ele conclui, perguntando: “O que isso lhe diz sobre a lei de falências?" 134 .

A teoria dos jogos pode ser usada de forma descritiva, prospectiva ou normativa. A primeira forma serve para conhecer melhor o comportamento dos jogadores. A

\footnotetext{
${ }^{133}$ No equilíbrio de Nash, a estratégia selecionada para cada jogador é a melhor resposta possível às estratégias dos demais, e a hipótese é sempre válida para todos os envolvidos. (FIANI, Ronaldo. Teoria dos jogos. $2^{a}$ ed., São Paulo: Campus, 2006, pp. 93-94; 98-99; GINTIS, Herbert. Game theory evolving - A problem-centered introduction to modeling strategic interaction. Princeton: Princeton University Press, 2000, p. 13).

${ }^{134}$ GINTIS, Herbert. Game theory evolving - A problem-centered introduction to modeling strategic interaction. Princeton: Princeton University Press, 2000, p. 22 (tradução livre).
} 
segunda pode ser utilizada para prever as conseqüências derivadas da escolha de estratégias. A terceira serve para recomendar as melhores estratégias a serem seguidas.

Há críticas ao uso da teoria. Há entendimentos no sentido de que ela serve como teoria da informação, mas não para tomada de decisão, e que não se aplica a mercados regulados ${ }^{135}$. Também se critica o fato de que nem sempre os jogadores se comportam conforme as previsões quando, por exemplo, não conseguem aprender a cooperar ${ }^{136}$. Aponta-se também a inadequação para tratar situações nas quais o jogador adota estratégias mistas, variando comportamentos de forma aleatória. As críticas não invalidam a teoria dos jogos, mas sugerem que outras disciplinas, como, por exemplo, a psicologia, podem ser utilizadas para enriquecer a análise ${ }^{137}$.

\section{II.5.2. Teoria do desenho de mecanismos.}

A teoria do desenho de mecanismos ${ }^{138}$ tem por objetivo identificar e construir meios para minimizar as perdas geradas pelos agentes que detêm informação privada. A teoria tem múltiplos usos, entre eles, analisar jogos de informação incompleta, como, por exemplo, decisões coletivas, alocação de riscos, decisões de investimento, leilões, processos de votação.

Mecanismo é estrutura que fornece elementos para definir as instituições eficientes a partir das preferências e crenças dos jogadores. Leonid Hurwicz sugere desenhar mecanismos que permitam o cumprimento das regras pelos próprios agentes ${ }^{139}$, simplificando a supervisão sobre as instituições, pois é difícil e custoso garantir que os

${ }^{135}$ SALOMÃO FILHO, Calixto. Regulação da atividade econômica (princípios e fundamentos jurídicos). São Paulo: Malheiros, 2001, pp. 78-81.

${ }^{136}$ Robert Axelrod demonstrou que essa afirmação depende de outros fatores, que são tratados pela teoria dos jogos evolucionários, que não é objeto desse estudo. (AXELROD, Robert. The complexity of cooperation. Princeton: Princeton University Press, 1997).

${ }^{137}$ Ver: PARISI, Francesco; SMITH, Vernon. The law and economics of irrational behavior: an introduction. George Mason University Law and Economics Research Paper Series. Disponível em: <http://ssrn.com/abstract_id=586649>. Acesso em: 15.abr.2006; CAMERER, Colin F.; HO, Teck-Hua; CHONG, Juin-Kuan. A cognitive hierarchy theory of one-shot games and experimental analysis. September 8, 2003. Disponível em <http://www.ssrn.com>. Acesso em: 03.dez.2006.

${ }^{138}$ The Royal Swedish Academy of Sciences. The prize in economic sciences - information to the public. 2007. Disponível em <http://www.nobelprize.org>. Acesso em: 01.nov.2007 , pp. 1-6; The Royal Swedish Academy of Sciences. The prize in economic sciences - scientific background. 2007. Disponível em $<$ http://www.nobelprize.org>. Acesso em: 01.nov.2007, pp. 1-29.

${ }^{139}$ A expressão utilizada é "self-enforcement norm". 
supervisores também não necessitem de vigilância. Pretende-se evitar a existência de uma regressão infinita de controles que aumentariam os custos de transação, dificultando o cumprimento das leis e a consecução dos objetivos definidos para as instituições ${ }^{140}$.

Ronaldo Fiani entende que o desenho de mecanismos não serve somente para analisar qual a melhor estratégia que o jogador deve adotar. O mecanismo também é útil para definir os termos nos quais a interação estratégica deve ocorrer, isto é, permite que os jogadores participem da definição das regras do jogo. Deve-se analisar como as regras devem ser elaboradas para que determinado objetivo seja alcançado ${ }^{141}$. O jogador que desenha o jogo pode ser, por exemplo, o legislador.

Leonid Hurwicz define mecanismo como um sistema de captação de mensagens no qual os participantes enviam informação a uma “central de mensagens”. Depois, um conjunto de regras, predefinidas e conhecidas dos jogadores, atribui, com base nas informações recebidas, os ganhos a cada participante. Cada regra pode levar a diversos

\footnotetext{
140 "Ao contrário do que alguém possa pensar, ao colocar a famosa questão, Juvenal não estava preocupado com questões de estado ou de política, mas tentando convencer um amigo que casamento é uma insensatez, as mulheres não são confiáveis e mantê-las trancafiadas sob guarda não é solução, pois os guardas também não são confiáveis. Cerca de meio milênio depois, Platão levantou problema relacionado a este, ao discutir quais os padrões apropriados de comportamento para os guardiões da Cidade-Estado. Sócrates, referindo-se ao argumento de que a "embriaguez é muito inconveniente para os guardiões," afirma que: "Da intoxicação podemos dizer que eles devem abster-se. "O guardião é a última pessoa no mundo à qual é permitida a embriaguez". Glauco, interlocutor de Sócrates, responde: "Sim, seria absurdo que um guardião necessite de um guarda". "Ao contrário do pessimismo de Juvenal, Glauco expressa visão otimista de que as pessoas deveriam ser capazes de confiar que os guardiões irão se comportar adequadamente, e que seria absurdo imaginar que necessitem de supervisão". (...) "Voltemos ao problema inicial, da necessidade de supervisionar os guardiões. A questão cínica de Juvenal sugere não haver forma de supervisionar os guardas, porque é impossível garantir que as esposas se comportem da forma desejada. Além de haver 'guardas de primeira ordem' (aqueles que vigiam as esposas), seria também necessário haver 'guardas de segunda ordem' para supervisionar os de primeira ordem. Mas então, como aqueles também são suscetíveis à corrupção, será necessário haver 'guardas de terceira ordem', e assim por diante. Isto conduz à imagem de uma regressão infinita de guardiões, com a necessidade de ter o guardião de ordem ' $\mathrm{k}$ ' para supervisionar o guardião de ordem anterior, com $\mathrm{k}=2,3, \mathrm{~K}$, ao infinito. Se uma infinidade de guardiões não é recurso que está disponível, isso parece inviabilizar a possibilidade de garantir o cumprimento das leis! Porque nos preocupamos com o problema proposto por Juvenal (ou o problema dos 'maridos')? Principalmente porque alguns enxergam no problema uma parábola para a proposição de que garantir o cumprimento das leis é, em princípio, impossível, devido à regressão infinita de guardas". (...) "Quais são nossas conclusões? Para Juvenal, a garantia de cumprimento das leis (ou mais genericamente, implementação) não é sempre impossível. Mas mesmo quando é possível construir mecanismo teórico que implemente um critério ótimo, ainda seria o caso de se entender que aquela 'implementação genuína' (o conceito usado nesse artigo) é inviável ou muito custosa em termos de recursos, se o critério ignorar os custos de implementação". (HURWICZ, Leonid. But who will guard the guardians? May 1998. Disponível em $<$ http://www.econ.umn.edu/hurwicz>. Acesso em: 15.jan.2008, pp. 1; 11; 17) (tradução livre)

${ }^{141}$ FIANI, Ronaldo. Teoria dos jogos. $2^{\mathrm{a}}$ ed., São Paulo: Campus, 2006, pp. 316-317.
} 
resultados, ou equilíbrios, alcançados quando todos os agentes emitem mensagens que representam preferências. Equilíbrio é o conjunto de mensagens que maximiza os ganhos de cada participante, dadas as mensagens enviadas pelos demais.

Há duas importantes restrições impostas ao jogador que desenha o mecanismo: (i) ele não pode adotar nenhuma coerção, pois as regras devem permitir que todos joguem de forma voluntária e de acordo com interesses individuais; (ii) como todos os jogadores devem ser racionais, as expectativas do jogador que desenha o mecanismo devem ser razoáveis, isto é, os demais jogadores não devem ter incentivos para escolher estratégias que não sejam equilíbrios do jogo ${ }^{142}$.

Leonid Hurwicz introduz a noção de "compatibilidade de incentivos". Esta permite identificar equilíbrios equivalentes gerados por incentivos distintos, incorporando informações privadas de agentes auto-interessados que podem afetar a decisão. $\mathrm{O}$ conceito incorpora a possibilidade de que os agentes estejam mentindo na defesa dos próprios interesses. Um mecanismo será compatível se a revelação verdadeira da informação for estratégia dominante para o agente que a detém. Hurwicz demonstra que nenhum mecanismo é capaz de alcançar o critério de eficiência de Pareto, pois este é incompatível com a revelação voluntária de informação privada ${ }^{143}$. Do ponto de vista dos incentivos, mecanismo eficiente é aquele que maximiza a combinação de ganhos dos agentes envolvidos no jogo.

\footnotetext{
${ }^{142}$ FIANI, Ronaldo. Teoria dos jogos. $2^{\text {a }}$ ed., São Paulo: Campus, 2006, pp. 317; 321.

143 “Tomando como ponto de partida a premissa que a informação está dispersa entre os participantes do processo econômico, um processo pode ser definido como informacionalmente descentralizado quando cada unidade econômica (consumidor, empresa, etc.) somente possui informação sobre si mesma (preferências, tecnologias ou recursos), mas não sobre as características dos outros. O processo então requer trocas de sinais (mensagens) de forma a atingir objetivos, como a eficiência do sistema como um todo. Uma vez que a quantidade de informação conduzida pelos sinais foi quantificada, faz sentido discorrer a respeito de requerimentos informacionais dos processos se os objetivos devem ser atingidos em um ambiente específico. Em modelos rigorosamente formulados, por exemplo, foi possível provar que, na presença de retornos crescentes de escala, nenhum espaço de mensagens dimensionalmente finito é adequado para garantir a eficiência (no sentido de ótimo de Pareto) dos resultados de equilíbrio de qualquer processo informacionalmente descentralizado. Resultado similar foi obtido com externalidades negativas, como a poluição. Os resultados de impossibilidade aplicam-se não a um mecanismo particular ou estrutura institucional, mas a todos os mecanismos qualificados como informacionalmente descentralizados. Eles nos dizem que, mesmo assumindo que os participantes serão honestos e irão conformar-se com quaisquer regras do processo, nenhuma regra pode garantir alcançar os objetivos desejados. Tais resultados devem ser vistos como limitações específicas de implementação, devido à dispersão de informação, mesmo na presença de sanções perfeitas. Por isso, regras executáveis não são sempre um resultado alcançável". (HURWICZ, Leonid. But who will guard the guardians? May 1998. Disponível em <http://www.econ.umn.edu/hurwicz>. Acesso em: 15.jan.2008, pp. 3-4) (tradução livre)
} 
Além desses conceitos, introduz-se o princípio da revelação, a condição que faz com que o mecanismo direto seja compatível em termos de incentivos. A revelação simplifica escolhas quando há múltiplos resultados. Na busca da melhor solução para garantir o cumprimento das regras, permite restringir a análise aos mecanismos $\operatorname{diretos}^{144}$, que são os que satisfazem a condição de "compatibilidade de incentivos". Encontrar o mecanismo direto é tarefa intuitiva à qual se sucede sua adaptação à realidade.

Roger Myerson demonstra que o princípio da revelação também é válido em situações em que há "risco moral" ${ }^{145}$, e em mecanismos com múltiplos estágios de $\operatorname{decisão}^{146,147}$.

A revelação de informação não resolve o problema da existência de múltiplos equilíbrios com resultados inferiores. Eric Maskin pretende solucionar a questão com a teoria da implementação, segundo a qual é possível desenhar mecanismos nos quais todos os resultados são “ótimos” para uma determinada finalidade. Maskin enfatiza o problema dos incentivos, demonstrando que o equilíbrio requer a ocorrência de três condições: (i) monotonicidade, isto é, se a alternativa socialmente eficiente não perde importância na ordem de preferências de nenhum agente, então ela continua sendo socialmente ótima; (ii) que não haja poder de veto dos agentes; (iii) que haja ao menos três agentes e, neste caso, a segunda condição é desnecessária ${ }^{148}$.

\footnotetext{
${ }^{144}$ Ronaldo Fiani define mecanismo direto como um jogo bayesiano simultâneo no qual os jogadores informam seu tipo a um árbitro que utiliza as informações recebidas para determinar os ganhos de cada jogador. $\mathrm{O}$ autor entende que o mecanismo direto apresenta a vantagem de impedir que o jogador obtenha ganhos significativos ao mentir ao árbitro a respeito de suas preferências. (FIANI, Ronaldo. Teoria dos jogos. $2^{\mathrm{a}}$ ed., São Paulo: Campus, 2006, pp. 326).

${ }^{145} \mathrm{O}$ problema do risco moral (moral hazard) surge quando o indivíduo pode influenciar o grau de risco, alterando comportamentos posteriormente à contratação e afetando a capacidade dos mercados de alocar recursos eficientemente. (PINDYCK, Robert S.; RUBINFELD, Daniel L. Microeconomia. São Paulo: Makron Books, 1994, p. 817)

${ }^{146}$ The Royal Swedish Academy of Sciences. The prize in economic sciences - scientific background. 2007. Disponível em <http://www.nobelprize.org>. Acesso em: 01.nov.2007, p. 5.

${ }^{147} \mathrm{O}$ princípio da revelação é bastante usado no desenho de leilões, para resolver jogos de informação incompleta. (The Royal Swedish Academy of Sciences. The prize in economic sciences - information to the public. 2007. Disponível em <http://www.nobelprize.org>. Acesso em: 01.nov.2007, p. 2)

${ }^{148}$ The Royal Swedish Academy of Sciences. The prize in economic sciences - scientific background, 2007. Disponível em <http://www.nobelprize.org>. Acesso em: 01.nov.2007, pp. 13-14; 17-19; Ver também: MASKIN, Eric; SJÖSTRÖM, Tomas. Implementation theory. September 17, 2001. Disponível em $<$ http://www.sss.ias.edu/publications/economicsworking.php>. Acesso em: 15.jan.2008, pp.5-6; 15.
} 
O princípio da revelação permite tornar as estratégias legais mais atrativas do que as ilegais e o cumprimento de regras uma atitude voluntária por parte dos agentes. Leonid Hurwicz entende que um jogo com regras jurídicas está sendo bem executado quando, para os resultados do "jogo real”, as estratégias ilegais são dominadas por alguma estratégia legal. Segundo ele, o conceito tradicional de implementação assume que nenhum jogador usará estratégias fora das permitidas pelo jogo. Seu conceito, ao contrário, envolve atividades desenhadas para tornar o jogo efetivo, desencorajar o uso de estratégias proibidas e fazer com que o resultado esperado seja alcançado. Nesse caso, é o "jogo ideal” que está sendo implementado; a comparação se dá entre o "jogo verdadeiro" e o "jogo ideal”, ao invés de o "jogo ideal” relacionar-se apenas com o critério definido para avaliar o jogo ${ }^{149}$. A análise proposta por Hurwicz indica que o “jogo ideal” corresponde à legislação vigente, e o "jogo verdadeiro" representa a realidade fática. $\mathrm{O}$ autor propõe que se analise a adequação da aplicação das leis à realidade, não a adequação das leis aos princípios e critérios legais ${ }^{150}$.

149 HURWICZ, Leonid. But who will guard the guardians? May 1998. Disponível em $<$ http://www.econ.umn.edu/hurwicz>. Acesso em: 15.jan.2008, pp. 5-6; 10.

150 "Uma implementação é bem sucedida se o resultado de equilíbrio corresponde àqueles previstos pelo jogo ideal, ou seja, aquelas previstas pela legislação". (...) "No contexto da maioria dos mecanismos considerados na literatura, a definição deve ser mais bem qualificada. A razão é que a implementação requer o uso de recursos. Se o modelo não os considera, tipicamente requer mais eficiência relativamente ao total de recursos existentes na economia ('eficiência bruta'). Isso é impraticável quando os recursos necessários para a implementação são restritos. No melhor caso, alguém pode imaginar haver eficiência relativa aos recursos desviados da implementação ('eficiência líquida'). Conseqüentemente, mesmo se a implementação for bem sucedida, somente resultará em equilíbrios com 'eficiência líquida' e o equilíbrio de 'eficiência bruta' será desconsiderado". (HURWICZ, Leonid. But who will guard the guardians? May 1998. Disponível em <http://www.econ.umn.edu/hurwicz>. Acesso em: 15.jan.2008, pp. 10-12) (tradução livre) 


\section{Modelo ${ }^{151}$.}

\section{III.1. Preferências ${ }^{152}$.}

De acordo com a teoria da escolha racional, agentes econômicos têm preferências positivas (desejos) e negativas (aversões). O termo é utilizado como sinônimo de interesses.

Erasmo França define interesse como a relação existente entre a necessidade de um sujeito e o bem apto a satisfazê-la, tutelada por uma previsão abstrata de uma norma que regula tal relação ${ }^{153}$.

Se há crise da empresa, sempre existem interesses conflitantes. Devedor e credores entram em conflito pelos direitos de propriedade sobre os bens, sendo necessário estabelecer a delimitação inicial, custos de monitoração e regras para distribuição dos direitos.

Yoram Barzel entende que o termo propriedade tem dois sentidos: o econômico, definido pela possibilidade de usufruir determinado bem, consumindo-o diretamente, ou indiretamente, através da troca, e o sentido jurídico, que são os direitos reconhecidos e garantidos pelas instituições e atribuídos ao indivíduo. O primeiro representa a finalidade da propriedade e o segundo é meio para garanti-la. O conceito está relacionado com a noção de custos de transação, porque há custos para transferir,

\footnotetext{
${ }^{151}$ Neste capítulo, apresenta-se o modelo proposto, que utiliza conceitos da teoria dos jogos, teoria de desenho de mecanismos e a estrutura conceitual da teoria da escolha racional. Os conceitos foram introduzidos no capítulo II.

${ }^{152}$ Nosso trabalho não discute as complexas questões metodológicas a respeito da definição de interesse individual, coletivo e público, mas apenas adota definição útil aos propósitos da análise. Os problemas metodológicos são tratados em detalhe em: CHIAPPIN, J. R. N.; LEISTER, Ana C. Reconstrução racional do programa de pesquisa da política, e do direito, como ciência e da abordagem do problema da emergência e estabilidade da cooperação entre indivíduos interagentes. A construção do Estado de Direito e o núcleo teórico do contratualismo. Não publicado, 2007; CHIAPPIN, J. R. N.; LEISTER, Ana C. Reconstrução racional do programa de pesquisa da política, e do direito, como ciência e da abordagem do problema da emergência e estabilidade da cooperação entre indivíduos interagentes. A construção do Estado de Direito e a heurística do contratualismo. Não publicado, 2007.

${ }^{153}$ FRANÇA, Erasmo V. de A. e N., Conflito de interesses nas assembléias de S. A. São Paulo: Malheiros Editores, 1993, pp. 15-16.
} 
capturar e proteger os direitos ${ }^{154,} 155$.

Guido Calabresi e Douglas Melamed demonstram que a proteção a direitos depende de haver regras de propriedade, responsabilidade e inalienabilidade. As primeiras têm baixa interferência estatal e determinam que o indivíduo que queira retirar um direito de outro deve negociar o bem, adquirindo-o por meio da troca. As segundas determinam que o indivíduo que destruir propriedade alheia deve compensar o ofendido, cabendo ao Estado estabelecer o valor de compensação. As terceiras são regras que impedem os particulares de negociarem certos bens em função do interesse público. A atribuição dos direitos ocorre por razões de eficiência na alocação dos recursos, objetivos de distribuição de riqueza e outras considerações de justiça ${ }^{156}$. Tais regras impõem restrições à autonomia da vontade, afetando os interesses dos agentes.

As preferências orientam a escolha de estratégias que viabilizam os resultados esperados. Relacionam-se com o valor e a forma de distribuição dos bens objeto de conflito. A disputa pela propriedade da empresa em crise é motivo de conflito a respeito de como será feita a partilha do "valor correspondente ao negócio e aos bens que compõem a empresa”, não significando que os credores desejam controlar o negócio ou assumir o controle da empresa.

Os interesses condicionam a forma pela qual os indivíduos respondem a incentivos. Os interesses podem ser classificados em função dos agentes afetados, podendo haver interesses individuais, coletivos ou comuns e interesse público ${ }^{157}$.

${ }^{154}$ BARZEL, Yoram. Economic analysis of property rights. $2^{\text {nd }}$ ed., New York: Cambridge University Press, 2003, pp. 3-4.

${ }^{155}$ Rachel Sztajn, Decio Zylberstajn e Bernardo Mueller entendem que a idéia de direitos de propriedade funda-se no conjunto de direitos que podem ser chamados de subjetivos, incluindo os direitos reais e pessoais, bens suscetíveis de apropriação e negociação, não se limitando à noção utilizada pelo direito. (SZTAJN, Rachel; ZYLBERSTAJN, Decio; MUELLER, Bernardo. Economia dos Direitos de Propriedade. In ZYLBERSTAJN, Decio; SZTAJN, Rachel (coord.). Direito e Economia - Análise econômica do direito e das organizações. São Paulo: Campus, 2005, pp. 84-101). Na mesma linha: COMPARATO, Fabio K. Aspectos jurídicos da macro-empresa. São Paulo: Revista dos Tribunais, 1970, p. 70.

${ }^{156}$ CALABRESI, Guido; MELAMED, Douglas A. Property rules, liability rules, and inalienability: one view of the cathedral. Harvard Law Review, V. 85, n. 6, April 1972, pp. 1089-1093; CALABRESI, Guido. Remarks: The simple virtues of The Cathedral. Yale Law Journal, n. 106, 1996-1997, pp. 2201-2207.

${ }^{157}$ Erasmo França entende que o interesse público, o interesse coletivo dos credores e o interesse particular de devedor e dos credores convivem na LREF, nem sempre de forma harmoniosa. (FRANÇA, Erasmo Valladão de A e N. Comentários. In SOUZA JR, Francisco Satiro de; PITOMBO, Antonio Sérgio A de Moraes (coord.). Comentários à lei de recuperação de empresas e falência. São Paulo: Revista dos 
$\mathrm{O}$ interesse individual refere-se às preferências de devedor e credores, considerados de maneira isolada. Refere-se ao agente racional e auto-interessado ${ }^{158}$, mas não independente ${ }^{159}$, que escolhe a estratégia que lhe traz maior benefício líquido, isto é, maximiza ganhos e minimiza perdas individuais. Orienta-se pela supremacia do interesse próprio ${ }^{160}$. Para o devedor, significa pagar o menor valor possível dos créditos e para os credores, receber a maior parcela possível do valor. O principal incentivo individual é o valor monetário líquido a receber, ao final da negociação a respeito da recuperação da empresa. Erasmo França esclarece que o interesse individual dos credores é o recebimento dos créditos, de acordo com o princípio da par conditio creditorum $^{161}$.

O interesse comum ou coletivo refere-se à coletividade de credores da empresa. Ele limita a autonomia privada (interesse individual), fazendo prevalecer o interesse comum ${ }^{162}$. Orienta-se pela supremacia dos interesses não-individuais de uma coletividade uniforme de pessoas. São interesses homogêneos, se considerados individualmente, mas recebem tratamento coletivo porque tal medida é benéfica para a coletividade. O interesse coletivo traduz-se em: (i) garantia de maximização do valor

Tribunais, 2005, pp. 187-189). Calixto Salomão Filho entende que a LREF não regula de forma adequada a relevância atribuída aos diversos grupos de interesses envolvidos. (SALOMÃO FILHO, Calixto. Recuperação de empresas e interesse social. In SOUZA JR, Francisco Satiro de; PITOMBO, Antonio Sérgio A de Moraes (coord.). Comentários à lei de recuperação de empresas e falência. São Paulo: Revista dos Tribunais, 2005, p. 52)

${ }^{158}$ Exclui-se do modelo proposto a hipótese de haver devedor ou credor altruísta. Conforme demonstrou Douglass North, ao ceder direitos sem a devida contrapartida, o altruísta reduz o bem-estar individual. (NORTH, Douglass C. Institutions, institutional change and economic performance. New York: Cambridge University Press, 2002, pp. 20-25)

${ }^{159} \mathrm{O}$ agente independente é pressuposto da teoria da escolha racional. A teoria dos jogos demonstra que ele não é independente, mas realiza escolhas em função das escolhas realizadas pelo oponente (Seção II.5.1).

${ }^{160}$ CHIAPPIN, J. R. N.; LEISTER, Ana C. Reconstrução racional do programa de pesquisa da política, e do direito, como ciência e da abordagem do problema da emergência e estabilidade da cooperação entre indivíduos interagentes. A construção do Estado de Direito e a heurística do contratualismo. Não publicado, 2007, p. 8.

${ }^{161}$ FRANÇA, Erasmo Valladão de A e N. Comentários. In SOUZA JR, Francisco Satiro de; PITOMBO, Antonio Sérgio A de Moraes (coord.). Comentários à lei de recuperação de empresas e falência. São Paulo: Revista dos Tribunais, 2005, p. 188.

${ }^{162}$ CHIAPPIN, J. R. N.; LEISTER, Ana C. Reconstrução racional do programa de pesquisa da política, e do direito, como ciência e da abordagem do problema da emergência e estabilidade da cooperação entre indivíduos interagentes. A construção do Estado de Direito e a heurística do contratualismo. Não publicado, 2007, p. 9. 
em disputa e justa avaliação dos ativos da empresa; (ii) respeito à regra da maioria ${ }^{163}$ nas deliberações coletivas; (iii) justiça na partilha do valor, respeitando-se a ordem de classificação e pagamento de créditos. Funda-se na idéia de obtenção de vantagens mútuas, mesmo que seja necessário sacrificar o interesse individual. O principal incentivo para os credores é a maximização do valor dos ativos da empresa, seguido da distribuição de acordo com as "regras do jogo" ${ }^{164}$. Erasmo França explica que o interesse comum ou coletivo pode ser alcançado na assembléia geral por meio do regular desenvolvimento da recuperação da empresa viável, falência da inviável, constituição do comitê de credores, nomeação do gestor judicial, modalidades de realização do ativo, etc. ${ }^{165}$.

O problema, entretanto, parece ser a dificuldade em alinhar as preferências individuais e coletivas. O tema foi tratado por Kenneth Arrow no Teorema da Impossibilidade, o qual estabelece que, sob certas condições, é impossível garantir tal alinhamento. Isso ocorre, por exemplo, quando a ordem de votações altera os resultados do jogo ${ }^{166}$.

O interesse público refere-se à sociedade civil, coletividade de pessoas indiretamente afetadas pela crise. É generalização do interesse coletivo, abrangendo interesses de terceiros não envolvidos com o procedimento concursal. $\mathrm{O}$ interesse público orienta-se pela supremacia do bem-estar geral em detrimento do individual ou coletivo. Em direito concursal, significa realizar, ao menor custo possível, a preservação da empresa viável e liquidação da inviável, pois há interesse público na alocação eficiente dos ativos da empresa, tornando-os mais produtivos para maximizar

\footnotetext{
${ }^{163}$ A regra da maioria é aquela que satisfaz a opinião de mais da metade dos votantes. A regra aplica-se de maneira bastante simples quando há apenas duas escolhas, porém, pode ser insuficiente quando há três ou mais alternativas porque pode levar a resultados não condizentes com a vontade da maioria. Assim, por exemplo, se há três opções, $\mathrm{X}, \mathrm{Y}$ e $\mathrm{Z}$, pode haver um grupo majoritário que prefira $\mathrm{X}$ a $\mathrm{Y}$, outro grupo diferente que prefira $\mathrm{Z}$ a X, e outro que prefira $\mathrm{Y}$ a Z. (FIANI, Ronaldo. Teoria dos jogos. $2^{\mathrm{a}}$ ed., São Paulo: Campus, 2006, pp. 27-29). Ver detalhamento do problema nas seções III.3 e IV.3.2.

${ }_{164}$ No sentido adotado por Douglass North (ver nota 2).

${ }^{165}$ FRANÇA, Erasmo Valladão de A e N. Comentários. In SOUZA JR, Francisco Satiro de; PITOMBO, Antonio Sérgio A de Moraes (coord.). Comentários à lei de recuperação de empresas e falência. São Paulo: Revista dos Tribunais, 2005, pp. 187-188.

${ }^{166}$ DAVIS, Morton D. Teoria dos jogos - uma introdução não técnica. Tradução: Leonidas Hezenberg. São Paulo: Cultrix, 1973, pp. 207-208. Ver detalhamento do problema nas seções III.3 e IV.3.2.
} 
o bem-estar geral ${ }^{167}$.

O interesse individual e o interesse público preexistem ao concurso. Sempre será do interesse do credor individual maximizar o valor a receber do devedor e este, por sua vez, sempre tem interesse em pagar o menor valor possível dos créditos. Também é sempre de interesse público que os ativos existentes estejam alocados ao empreendimento mais apto a suprir as demandas do mercado. $\mathrm{O}$ interesse comum ou coletivo, ao contrário, surge com o procedimento concursal, depende da capacidade de organização dos credores e da existência de regras que permitam agregar e tratar o interesse das diversas categorias envolvidas.

Há distintos níveis de custos de transação associados a cada tipo de interesse. Os custos relativos aos interesses individuais são os prejuízos decorrentes da crise, experimentados por devedores e credores. Em relação ao interesse coletivo, são os custos diretos e indiretos, incorridos com a negociação coletiva. $\mathrm{O}$ interesse público congrega os custos totais incorridos, inclusive prejuízos indiretos suportados pela sociedade civil.

A LREF tem por objetivo perseguir os três tipos de interesses, mas os critérios legais adotados são insuficientes para dirimir os conflitos existentes ${ }^{168}$. A lei não indica a prevalência de nenhum dos três tipos de interesse. O art. 47 é uma declaração de intenções que não indica conceitos mensuráveis de bem-estar social ${ }^{169}$. Em relação aos interesses coletivos, a lei não indica a prevalência de nenhuma classe de credores sobre

\footnotetext{
${ }^{167}$ Nesse sentido, ver princípios expressos no Projeto de Lei PLC n. 71/03 e modificações incorporadas à lei: “(...) 3) Recuperação das sociedades e empresários recuperáveis: sempre que for possível a manutenção da estrutura organizacional ou societária, ainda que com modificações, o Estado deve dar instrumentos e condições para que a empresa se recupere, estimulando, assim, a atividade empresarial. 4) Retirada do mercado de sociedades ou empresários não recuperáveis: caso haja problemas crônicos na atividade ou na administração da empresa, de modo a inviabilizar sua recuperação, o Estado deve promover de forma rápida e eficiente sua retirada do mercado, a fim de evitar a potencialização dos problemas e o agravamento da situação dos que negociam com pessoas ou sociedades com dificuldades insanáveis na condução do negócio". (Íntegra da publicação da LREF, in <http://www.senado.gov.br>. Acesso em: 17.mai.2006)

${ }^{168}$ Erasmo França entende que não há suficientes regras na LREF para tratamento de conflitos de interesse. (FRANÇA, Erasmo Valladão de A. e N. Comentários. In SOUZA JR, Francisco Satiro de; PITOMBO, Antonio Sérgio A de Moraes (coord.). Comentários à lei de recuperação de empresas e falência. São Paulo: Revista dos Tribunais, 2005, p. 192).

${ }^{169}$ LREF, Art. 47. "A recuperação judicial tem por objetivo viabilizar a superação da situação de crise econômico-financeira do devedor, a fim de permitir a manutenção da fonte produtora, do emprego dos trabalhadores e dos interesses dos credores, promovendo, assim, a preservação da empresa, sua função social e o estímulo à atividade econômica".
} 
as demais, mas os critérios de votação do plano de recuperação podem permitir a determinados credores monopolizar as decisões sobre o destino da empresa. Há credores que não são afetados pela recuperação judicial, mas que podem inviabilizá-la, como, por exemplo, o credor fiscal. Há credores atingidos pela recuperação que têm pouca ou nenhuma influência sobre o procedimento concursal, como por exemplo, o trabalhador da empresa. A lei também parece preferir a recuperação à falência e a preservação da unidade produtiva à venda de ativos para pagar credores específicos. Não há prevalência dos interesses da propriedade nacional em detrimento da estrangeira nem tutela da coletividade e dos interesses de consumidores. A lei também não trata os efeitos de segunda ordem, decorrentes da decisão de recuperação ou falência ${ }^{170,171}$.

A LREF não alinhou os três tipos de interesses, podendo haver conflitos entre os agentes porque os incentivos legais não garantem a distribuição adequada dos direitos sobre os ativos da empresa em crise.

\section{III.2. Restrições ${ }^{172}$.}

A restrição fundamental que afeta o comportamento de devedores e credores é a avaliação da empresa em crise. $\mathrm{O}$ interesse dos agentes depende de conhecer o valor dos ativos submetidos a concurso, isto é, quanto do valor dos créditos será objeto de negociação ${ }^{173}$. O valor apurado indica o total de ganhos e perdas suportados pelos agentes ao final do procedimento. É informação imperfeita e incompleta.

Suponha que a empresa tenha débitos no valor de 100, sendo que os credores com garantia devam receber 60 , os trabalhistas 10 e os demais 30 . Se a empresa é avaliada em 100, todos terão interesse em negociar. Se a avaliação for de 40, os credores sem garantia podem ter menor disposição para negociar porque haverá pouca

\footnotetext{
${ }^{170}$ Para confronto com a lei concursal italiana, ver: STANGHELLINI, Lorenzo. Crisi di impresa fra diritto ed economia - le procedure di insolvenza. Bologna: Il Mulino, 2007, pp. 110-115.

${ }^{171}$ Estes e outros aspectos são discutidos em detalhes nos capítulos III e IV.

${ }^{172}$ Essa seção limita-se a discutir apenas as principais restrições. Há outras, específicas, que sevem para limitar hipóteses previstas no modelo, descritas na seção III.3.

${ }^{173}$ ROE, Mark J. Corporate reorganization and bankruptcy - legal and financial materials. University Casebook Series, New York: Foundation Press, 2000, pp.19-20; 579-580.
} 
possibilidade de receberem qualquer valor ${ }^{174}$.

A avaliação é evento de natureza subjetiva, pois nem todos os atributos de valor da empresa podem ser mensurados de modo preciso. Problema fundamental é o da especificidade de ativos, pois quando esta é alta há maior dificuldade em realocá-los para outros empreendimentos, afetando a avaliação ${ }^{175}$. Também o know-how detido pelos trabalhadores e os bens intangíveis - a marca, processos produtivos, pontos comerciais - são, muitas vezes, avaliados de maneira inadequada ${ }^{176}$.

A avaliação pode ser realizada de três maneiras: (i) forma judicial; (ii) forma de mercado; (iii) forma direta, pelas partes. A primeira é obtida pelo juiz e auxiliares ou terceiros contratados para a tarefa. A segunda é alcançada pela estimativa do valor que a empresa alcançaria se fosse vendida no mercado. A terceira é realizada pelos interessados, muitas vezes com base em informações judiciais e de mercado.

A avaliação judicial é evento com razoável grau de incerteza porque o juiz e o administrador judicial, geralmente, têm menos informação que o devedor ou os credores a respeito da crise da empresa e do funcionamento dos mercados. Segundo Mark Roe, os juízes acreditam que o mercado avalia a empresa por valor abaixo do ideal devido às incertezas sobre o futuro. Entretanto, o valor é baixo porque a empresa tem poucas oportunidades de negócio e a continuidade das operações é incerta. Por isso,

\footnotetext{
${ }^{174}$ Essa afirmação, entretanto, não considera o problema da variação do grau de tolerância a riscos dos agentes. Tema controvertido - e não tratado por este trabalho - é aquele que relaciona a natureza dos débitos da empresa e o risco assumido pelos fornecedores de capital. A doutrina clássica indica que o credor tende a ter menor tolerância relativa a riscos, ao passo que o acionista seria mais propenso a assumi-los. Na verdade, ambos são capazes de tomar risco, mas pode haver distintos níveis de tolerância relativa a riscos, isto é, um grupo pode ser propenso a tomar mais riscos do que o outro, dependendo das circunstâncias.

${ }_{175}$ De acordo com Oliver Williamson, a forma como os ativos são negociados depende da especificidade dos ativos, incerteza e frequiência das transações. A especificidade de ativos é o mais importante, decisivo na avaliação dos direitos e também na forma como os agentes se comportam. Há alta especificidade se a utilização e propósito do ativo são muito específicos. Há baixa especificidade se o ativo tem propósito genérico, podendo ser usado em várias situações. Há quatro tipos de especificidade: de local, de ativos físicos, de ativos humanos e os ativos dedicados. A incerteza significa a dificuldade de adaptação às mudanças nas circunstâncias de tempo e espaço. A frequiência de transações significa que somente faz sentido criar estruturas especiais de gestão se as transações de mercado são dispendiosas ou muito freqüentes. A relação entre os três elementos afeta a forma como os ativos são contratados e geridos. (WILLIAMSON, Oliver. The economic institutions of capitalism. New York: Free Press, 1987, pp. 52-59; 68-80)

${ }^{176}$ Lynn Lopucki entende que a empresa é organização composta por pessoas e ativos, dirigida pelo empresário para reduzir custos de transação, com valor econômico maior que apenas o conjunto de bens físicos. (LOPUCKI, Lynn. The nature of the bankrupt firm: a reply to Baird and Rasmussen's 'The End of Bankruptcy'. Stanford Law Review, v. 56, 2003/2004, pp. 645-672)
} 
o autor indica que os juízes tendem a desconfiar da avaliação de mercado, mas evitam realizar a forma judicial, transferindo a tarefa para as partes. Mark Roe aponta que as partes, ao realizarem a avaliação, especulam a respeito da "estimativa de valor que o juiz atribuiria à empresa” ${ }^{177}$. A avaliação é, portanto, um valor de comparação que pode tomar a forma de negociação, uma proposta de pagamento de determinado montante no plano de recuperação. Para efeito de comparação, tal valor não deveria ser menor que a estimativa de recebimento em caso de liquidação da empresa.

Mark Roe esclarece que a incerteza a respeito da avaliação judicial cria incentivos para os credores sem garantia questionarem o valor, aumentando o interesse em alongar o procedimento concursal pelo maior tempo possível. Isso pode ocorrer por três razões: (i) se a avaliação inviabiliza o recebimento dos créditos, não há interesse em finalizar o procedimento e são adotadas estratégias para prolongamento dos $\operatorname{prazos}^{178}$; (ii) se a empresa experimenta declínio nas operações, são os credores com garantia e os trabalhistas que sofrem as maiores perdas decorrentes do atraso, situação definida como "efeito carona" ${ }^{179}$ : os credores sem garantia perdem apenas os créditos já devidos, enquanto os demais credores sofrem com a deterioração das garantias e das condições de trabalho na empresa; (iii) se há melhora nas operações, os credores sem garantia aumentam as chances de receberem algum valor, podendo ser beneficiados em proporção maior, valendo-se do "efeito carona" ${ }^{180}$.

A demora natural ou provocada do procedimento concursal implica em custos de transação que não são assumidos por aquele que provoca o atraso, sendo difícil provar a culpa e responsabilizar o causador do atraso. É similar ao "problema dos recursos comuns", no qual as decisões individuais, embora racionais, levam a resultados inferiores do ponto de vista do interesse público, com dilapidação dos $\operatorname{ativos}^{181}$.

${ }^{177}$ ROE, Mark J. Corporate reorganization and bankruptcy - legal and financial materials. University Casebook Series, New York: Foundation Press, 2000, pp. 35-39; 580.

${ }_{178}^{178}$ A teoria dos jogos utiliza-se da expressão "strategic delays" para expressar tal noção.

${ }^{179}$ Efeito carona, ou "free riding", é situação na qual o agente obtém porção maior dos recursos ou suporta porção menor dos custos do que lhe seria atribuído.

${ }_{180}$ ROE, Mark J. Corporate reorganization and bankruptcy - legal and financial materials. University Casebook Series, New York: Foundation Press, 2000, pp. 580-581.

${ }^{181} \mathrm{O}$ problema dos recursos comuns indica que quando os direitos de propriedade não são bem definidos, os recursos tendem a se deteriorar mais rapidamente do que quando há definição precisa. (DEMSETZ, Harold. 
A avaliação pelo mercado é método mais eficiente. Há duas maneiras de realizá-la: (i) vender a empresa no mercado ${ }^{182}$; (ii) vender um percentual das ações no mercado e extrapolá-lo ${ }^{183}$ para estimar o valor da empresa. Ambas são formas imperfeitas, mas apresentam a vantagem de serem aproximações da realidade, obtidas a custo mais baixo. Além disso, os credores podem ser pagos em dinheiro, ações ou cotas sociais avaliadas a preço de mercado, tornando o método operacional.

Alterações no valor da empresa relacionam-se com: mudanças na estrutura de capital que afetam o fluxo de caixa futuro; existência de informação assimétrica; fatores que influenciam o entendimento das partes sobre a perspectiva de resultados futuros, oportunidades de investimentos e valor dos ativos da empresa. O problema pode ser estudado com base em três teorias: (i) teoria da sinalização e informação assimétrica; (ii) teoria da estrutura de capital; (iii) teoria da demanda ${ }^{184}$.

A teoria da sinalização e informação assimétrica indica que os administradores da empresa detêm informação privada sobre o valor do negócio, não conhecida pelos credores. Por isso, o devedor pode exagerar a qualidade dos projetos da empresa que

Toward a theory of property rights. The American Economic Review, V. 57, n. 2, Papers and Proceedings of the Seventy-ninth Annual Meeting of the American Economic Association, pp. 347-359, May 1967. Disponível em <http://www.ssrn.com>. Acesso em: 03.out.2006). Ver também: ROE, Mark J. Corporate reorganization and bankruptcy - legal and financial materials. University Casebook Series, New York: Foundation Press, 2000, pp. 136-140, 581; SZTAJN, Rachel. Apontamentos em matéria de empresas em crise - falência e liquidação extrajudicial. In SADDI, Jairo (coord.). Intervenção e liquidação extrajudicial no sistema financeiro nacional - 25 anos da Lei 6.024/74. São Paulo: TextoNovo, 1999, p. 236. Ver descrição detalhada do Dilema do Prisioneiro na seção II.5.1.

${ }^{182}$ A venda como um todo no mercado é o valor de venda como going concern. Segundo Robert Clark, "é o valor como negócio funcional e integrado, e, em um negócio bem sucedido, é substancialmente maior que a soma dos valores de venda dos bens e direitos detidos pela empresa considerados isoladamente. Um negócio saudável vale mais vivo do que morto". (CLARK, Robert C. Corporate law. New York: Aspen Law and Business, 1986, p. 14). Para Lorenzo Stanghellini, é o valor da atividade mantida em funcionamento, superior ao valor de liquidação dos ativos. Entende que o valor é próximo do valor do aviamento da empresa, mas não coincide com ele. (STANGHELLINI, Lorenzo. Crisi di impresa fra diritto ed economia - le procedure di insolvenza. Bologna: Il Mulino, 2007, pp. 68-69).

${ }^{183}$ Extrapolação e interpolação são técnicas matemáticas usadas para medir a relação entre variáveis com o objetivo de fazer previsões. (SANDRONI, Paulo. Dicionário de Economia. $3^{\text {a }}$ ed., São Paulo: Best Seller, 1994, p. 119; HOEL, Paul G. Estatística elementar. São Paulo: Atlas, 1977, pp. 175-176). Nesse caso, referese a estimar um percentual do valor das ações da empresa e projetá-lo ao restante para obter uma estimativa do valor total.

${ }^{184}$ Claudio Vilar Furtado descreve as teorias, tomando como objeto de estudo a oferta de emissão de ações de companhias abertas. Os argumentos, entretanto, podem ser aplicados ao problema da insolvência, pois o plano de recuperação é projeto de investimento que tem por objetivo a salvação da empresa. (FURTADO, Claudio V. Emissão de ações e valor de mercado da empresa: um estudo de ofertas primárias de ações negociadas em bolsas de valores no Brasil. Tese de Doutorado, São Paulo: EAESP/FGV, 1997). 
necessita de financiamento porque os credores não conhecem a real situação do negócio e a viabilidade do plano de salvação. Os credores podem supor que os administradores utilizariam outra solução, se dela dispusessem. Eles podem observar as atitudes daqueles quanto à disposição de também investirem capital próprio no projeto. Se os administradores e atuais acionistas investem novos recursos no projeto de salvação, sinalizam aos credores que o plano é viável, aumentando o valor da empresa. Se não investem, o valor de mercado da empresa diminui. De qualquer forma, os administradores tendem a preferir usar a alavancagem e salvar a empresa recorrendo ao endividamento externo, uma vez que a atitude permite transferir risco aos credores. Eles utilizarão recursos dos acionistas apenas se não dispuserem de solução melhor. Se os recursos dos credores puderem ser obtidos a taxas de juros atrativas estipuladas no plano de recuperação, os administradores preferirão tal alternativa. Por isso, segundo a teoria da sinalização e informação assimétrica, há dependência entre o valor da empresa e a decisão de financiá-la com capital próprio ou alheio ${ }^{185,}{ }^{186}$.

A teoria da estrutura de capital alcança conclusões opostas. Franco Modigliani e Merton Miller entendem que há independência entre a decisão de financiamento e o valor da empresa. Para eles, em mercados perfeitos, aplica-se a "lei de conservação do valor" que indica ser este invariável, não importando a estrutura de capital, isto é, se a empresa é financiada por acionistas ou credores. Segundo a lei de conservação, o valor do ativo deriva da capacidade de gerar renda para o proprietário, não importando a natureza dos direitos existentes sobre ele. A combinação de alternativas de financiamento é técnica financeira que não afeta a avaliação, a não ser que existam outros elementos que influenciem a decisão dos investidores, como, por exemplo, os impostos $^{187}$. Assim, segundo a teoria, a capacidade da empresa para criar ou destruir riqueza independe da estrutura de capital ${ }^{188}$. O modelo de invariância é afetado quando

\footnotetext{
${ }^{185}$ FURTADO, Claudio V. Emissão de ações e valor de mercado da empresa: um estudo de ofertas primárias de ações negociadas em bolsas de valores no Brasil. Tese de Doutorado, São Paulo: EAESP/FGV, 1997, pp.28-30; 38-39.

186 Esses aspectos são detalhados na seção III.3, na qual são discutidas as razões pelas quais os administradores optam pela reestruturação privada de dívidas ou pela recuperação judicial da empresa.

${ }^{187}$ MILLER, Merton H. Leverage. In ADLER, Barry E. Foundations of bankruptcy law. New York: Foundation Press, 2005, pp. 14-18; ROE, Mark J. Corporate reorganization and bankruptcy - legal and financial materials. University Casebook Series, New York: Foundation Press, 2000, pp. 19-20; 501-512.

${ }_{188}$ STANGHELLINI, Lorenzo. Crisi di impresa fra diritto ed economia - le procedure di insolvenza. Bologna: Il Mulino, 2007, pp. 18-20.
} 
são incorporados efeitos fiscais e outras restrições, situações na qual a estrutura de capital passa a ser relevante.

A teoria da demanda, por sua vez, aponta que o valor da empresa reflete a reavaliação desta pelo mercado, em razão de sinalizações dos administradores e acionistas. A teoria sugere que o mercado é capaz de refletir a informação contida nos preços e que as atitudes dos agentes que detêm informação privada sinalizam, a cada instante, o valor correto da empresa ${ }^{189}$. A premissa é que os mercados são "informacionalmente eficientes", isto é, capazes de avaliar e precificar, a todo instante, as informações recebidas.

As três teorias explicam apenas parcialmente o problema do endividamento e o reflexo sobre o valor da empresa em crise. Os administradores podem ser incentivados a atuar de maneira responsável com o objetivo de maximizar o valor da empresa quando, por exemplo, desejam manter a reputação pessoal, ou por receio de violar normas jurídicas. Ainda assim pode ocorrer o problema da seleção adversa ${ }^{190}$ na decisão de financiamento, pois empresas com bons projetos de salvação podem ser confundidas com as que apenas transferem o risco de continuidade do negócio aos credores.

O valor de mercado da empresa tende a aumentar quando existe expectativa consistente de aumento de investimentos e tende a diminuir quando há corte de projetos $^{191}$. Se o plano de recuperação não demonstrar a viabilidade do projeto de salvação nem o comprometimento de novos recursos dos atuais acionistas e administradores, os credores racionais deveriam rejeitá-lo e levar a empresa à falência.

${ }^{189}$ FURTADO, Claudio V. Emissão de ações e valor de mercado da empresa: um estudo de ofertas primárias de ações negociadas em bolsas de valores no Brasil. Tese de Doutorado, São Paulo: EAESP/FGV, 1997 , pp.34.

${ }^{190}$ O problema da seleção adversa indica que, na presença de informação assimétrica, há mudanças no comportamento daquele que detém a informação assimétrica após a contratação com a outra parte. Por exemplo, a oferta de seguros de saúde tende a atrair clientes com maior risco de apresentar doenças porque a seguradora tem dificuldade em distinguir o bom cliente (com baixo risco de doenças) do cliente indesejado. (AKERLOF, George. The market for lemons: quality uncertainty and the market mechanism. Quarterly Journal of Economics. V. 84, n. 3, pp. 488-500, August, 1970).

${ }^{191}$ Ver, em relação à emissão de ações: FURTADO, Claudio V. Emissão de ações e valor de mercado da empresa: um estudo de ofertas primárias de ações negociadas em bolsas de valores no Brasil. Tese de Doutorado, São Paulo: EAESP/FGV, 1997, p.31-33; 43. 
O nível de alavancagem da empresa afeta a análise do problema. A alavancagem pode ser definida como a proporção entre o valor do endividamento e o do capital próprio. No exemplo proposto por Lorenzo Stanghellini, se o empréstimo é remunerado à taxa de $8 \%$ e a empresa é capaz de gerar resultado líquido de $10 \%$, então tomar o empréstimo (alavancar-se) é interessante para o devedor porque produz ganho de $2 \%$ em cada período de tempo. Quanto maior a quantidade de capital emprestado, maior o retorno para a empresa. Analisando-se a tabela abaixo, proposta para a empresa eficiente, conclui-se que quanto maior o nível de endividamento, maior o rendimento obtido sobre o capital próprio ${ }^{192}$.

\begin{tabular}{|r|l|l|l|r|r|r|}
\hline $\begin{array}{l}\text { Capital } \\
\text { próprio }\end{array}$ & $\begin{array}{l}\text { Emprés- } \\
\text { timo }\end{array}$ & $\begin{array}{l}\text { Investimen- } \\
\text { to total }\end{array}$ & $\begin{array}{l}\text { Resultado } \\
\mathbf{( 1 0 \% )}\end{array}$ & $\begin{array}{l}\text { Juros } \\
\mathbf{( 8 \% )}\end{array}$ & $\begin{array}{l}\text { Resultado } \\
\text { líquido }\end{array}$ & $\begin{array}{l}\text { Rendimento } \\
\text { do capital } \\
\text { próprio }\end{array}$ \\
\hline 100 & zero & 100 & 10 & zero & 10,0 & $10 \%$ \\
\hline 80 & 20 & 100 & 10 & 1,6 & 8,4 & $10.5 \%$ \\
\hline 50 & 50 & 100 & 10 & 4,0 & 6,0 & $12 \%$ \\
\hline 20 & 80 & 100 & 10 & 6,4 & 3,6 & $18 \%$ \\
\hline 10 & 90 & 100 & 10 & 7,2 & 2,8 & $28 \%$ \\
\hline 1 & 99 & 100 & 10 & 7,9 & 2,1 & $210 \%$ \\
\hline
\end{tabular}

O raciocínio contrário também é verdadeiro. Se a empresa é ineficiente e destrói riqueza, sendo incapaz de produzir resultado que supere as taxas de juros do empréstimo, menor será o rendimento obtido sobre o capital próprio. No exemplo abaixo, quando o resultado líquido da empresa é de 5\%, quanto maior o nível de endividamento, menor o rendimento do capital próprio ${ }^{193}$ :

\begin{tabular}{|r|l|l|l|r|r|r|}
\hline $\begin{array}{l}\text { Capital } \\
\text { próprio }\end{array}$ & $\begin{array}{l}\text { Emprés- } \\
\text { timo }\end{array}$ & $\begin{array}{l}\text { Investimen- } \\
\text { to total }\end{array}$ & $\begin{array}{l}\text { Resultado } \\
\mathbf{( 5 \% )}\end{array}$ & $\begin{array}{l}\text { Juros } \\
\mathbf{( 8 \% )}\end{array}$ & $\begin{array}{l}\text { Resultado } \\
\text { líquido }\end{array}$ & $\begin{array}{l}\text { Rendimento } \\
\text { do capital } \\
\text { próprio }\end{array}$ \\
\hline 100 & Zero & 100 & 5 & zero & 5,0 & 5,00 \\
\hline 80 & 20 & 100 & 5 & 1,6 & 3,4 & 4,25 \\
\hline 50 & 50 & 100 & 5 & 4,0 & 1,0 & 2,00 \\
\hline 20 & 80 & 100 & 5 & 6,4 & $-1,4$ & $-7,00$ \\
\hline 10 & 90 & 100 & 5 & 7,2 & $-2,2$ & $-22,00$ \\
\hline 1 & 99 & 100 & 5 & 7,9 & $-2,9$ & $-290,00$ \\
\hline
\end{tabular}

${ }^{192}$ STANGHELLINI, Lorenzo. Crisi di impresa fra diritto ed economia - le procedure di insolvenza. Bologna: Il Mulino, 2007, pp. 20-21.

${ }^{193}$ STANGHELLINI, Lorenzo. Crisi di impresa fra diritto ed economia - le procedure di insolvenza. Bologna: Il Mulino, 2007, pp. 22-23. 
O efeito de alavancagem funciona com o incentivo para o empreendedor tomar empréstimos no mercado quando as taxas de juros são atrativas. $\mathrm{O}$ problema existe quando as taxas são maiores do que a capacidade da empresa de produzir riqueza. Eis o problema causado pela alavancagem, de difícil resolução pela legislação falimentar. A alavancagem beneficia o devedor da empresa eficiente, pois ele se apropria dos ganhos adicionais, repassando aos credores apenas os juros contratados. Quando a empresa é ineficiente e está em crise, a alavancagem prejudica os credores em proporção maior do que o devedor.

O valor da empresa eficiente se eleva se há aumento no nível de endividamento, pois o mercado supõe haver sinalização positiva a respeito da expectativa de resultados e de fluxo de caixa futuro. O contrário ocorre quando a empresa é ineficiente. Essa análise de curto prazo deve ser realizada sempre que a empresa propõe plano de recuperação aos credores, uma vez que é forma de inferir a seriedade da proposta feita pelo devedor.

É preciso saber também se tais conclusões também subsistem no longo prazo. O objetivo é tentar identificar se é possível avaliar os fundamentos do plano de recuperação e refleti-los na avaliação no valor atribuído à empresa, projetando para o futuro o sucesso ou fracasso da recuperação da empresa.

Para a teoria da demanda, as conclusões de curto prazo subsistem se a expectativa de fluxo de caixa futuro se mantiver conforme a previsão. O pedido de financiamento (leia-se, pedido de recuperação) será analisado pelos credores em termos da relação risco e retorno do investimento, e a decisão de investir será comparada a outras opções disponíveis no mercado. Entretanto, o devedor pode sonegar informações a respeito da empresa, por exemplo, motivos para a crise que não justifiquem o volume de recursos requerido ou o plano de pagamento proposto ${ }^{194}$.

${ }^{194}$ FURTADO, Claudio V. Emissão de ações e valor de mercado da empresa: um estudo de ofertas primárias de ações negociadas em bolsas de valores no Brasil. Tese de Doutorado, São Paulo: EAESP/FGV, 1997 , p.106. 
Para a teoria da sinalização e informação assimétrica o plano de recuperação transmite ao mercado um conjunto de informações positivas ou negativas. A alteração de valor da empresa subsistirá no longo prazo se refletir o desempenho futuro esperado, valor das operações atuais e projetos de investimentos disponíveis, já esperadas no curto prazo. Explicado de outro modo, decorrido algum tempo do anúncio do pedido de recuperação ou aprovação do plano, não deve haver variação significativa nos resultados esperados para a empresa ${ }^{195}$. O problema é que a informação somente pode ser verificada depois da aprovação do plano de recuperação, momento tardio para a tomada de decisão pelos credores.

Para a teoria da estrutura de capital, considerando a existência de impostos, o aumento da alavancagem, decorrente do financiamento obtido com o plano de recuperação, pode ter efeito positivo sobre o valor da empresa por diversas razões: (i) pode haver benefícios tributários associados à operação de financiamento; (ii) pode haver redistribuição do valor da empresa entre acionistas e credores, e os últimos passarem a deter parte maior dos direitos sobre os ativos da empresa; (iii) o aumento do endividamento pode constituir sinalização positiva que aumente o valor da empresa, quando, por exemplo, associa os investimentos a novos projetos ${ }^{196}$. A hipótese, entretanto, parece inconsistente com a realidade observada, uma vez que a empresa em crise perde valor de mercado por inúmeras razões não explicadas pela teoria.

A análise pressupõe a existência de mercado secundário para negociar os créditos da empresa. Para funcionar de maneira adequada, o mercado depende de produção de informações, agentes com capacidade de análise e volume significativo de negócios. Mark Roe entende ser necessário adotar mecanismos para controlar as distorções causadas pelos blocos de controle (credores com poder suficiente para manipular decisões), comportamentos estratégicos com o objetivo de aumentar a duração do procedimento e manipulação da atividade de avaliação ${ }^{197}$. A opção pela negociação por meio do mercado se justifica porque a avaliação judicial apresenta os

\footnotetext{
${ }^{195}$ FURTADO, Claudio V. Emissão de ações e valor de mercado da empresa: um estudo de ofertas primárias de ações negociadas em bolsas de valores no Brasil. Tese de Doutorado, São Paulo: EAESP/FGV, 1997, pp.109, 113.

${ }^{196}$ Ibid, pp.120-121.

${ }^{197}$ ROE, Mark J. Corporate reorganization and bankruptcy - legal and financial materials. University Casebook Series, New York: Foundation Press, 2000, pp. 582-587; 589.
} 
mesmos problemas, adicionando outros, como o aumento de custos, incertezas e prazos de solução para a crise.

As três teorias explicam apenas uma parte do problema da crise da empresa. A confirmação das conclusões depende de testar hipóteses com dados empíricos não disponíveis no Brasil. Além disso, a subjetividade da avaliação não foi mitigada pela LREF. Há dificuldades em analisar o valor da empresa, uma vez que não há parâmetros legais para orientar o cálculo. A lei também não permite reduzir todas as assimetrias de informação existentes ${ }^{198}$.

\section{III.3. Escolhas.}

Os agentes envolvidos no procedimento concursal realizam escolhas a partir de preferências, limitados pelas restrições existentes. As preferências e restrições foram tratadas nas seções anteriores. Nesta seção analisam-se as escolhas possíveis.

\section{III.3.1. Premissas.}

A crise da empresa é jogo não-cooperativo e de informação imperfeita e incompleta, porque há incerteza sobre a divisão de ganhos e os credores não conseguem saber se a empresa é eficiente ${ }^{199}$.

Supõe-se que o devedor permaneça no comando do negócio em recuperação ${ }^{200}$. Assume-se também que as classes de credores são grupos homogêneos capazes de se auto-organizarem, premissa não condizente com as regras existentes na $\mathrm{LREF}^{201}$.

\footnotetext{
198 Temas tratados no capítulo IV.

199 WEBB, David C. The importance of incomplete information in explaining the existence of costly bankruptcy. Economica, New Series, Vol. 54, n. 215, Aug. 1987, p. 279.

${ }^{200}$ Edward Altman indica que, nos Estados Unidos, o modelo, chamado de debtor-in-possession lending, baseia-se no interesse dos bancos em realizar o empréstimo porque possibilita intervir nas decisões da empresa, autoriza o recebimento de juros e a prestação de serviços. O autor explica que os empréstimos concedidos pelo agente financeiro tornam-se créditos extraconcursais. (ALTMAN, Edward I. Corporate financial distress and bankruptcy: a complete guide to predicting and avoiding distress and profiting from bankruptcy. $2^{\text {nd }}$ ed., New York: John Wiley, 1993, pp. 97-101)

${ }^{201}$ SZTAJN, Rachel. Notas sobre as assembléias de credores na lei de recuperação de empresas. Revista de Direito Mercantil, Industrial, Econômico e Financeiro, Ano XLIV, n. 138, abr./jun. 2005, pp. 58-59; BAROSSI FILHO, Milton. As assembléias de credores e plano de recuperação de empresas: uma visão da
} 
Lorenzo Stanghellini entende que os credores são grupo não-homogêneo, não previamente organizado e que toma decisões que nem sempre maximizam os ganhos para $\operatorname{todos}^{202}$.

Não modelamos os comportamentos do juiz, administrador judicial (art. 21), comitê de credores (art. 26), gestor judicial (art. 65), potenciais compradores da empresa e outros participantes do procedimento concursal (art. 50). Desconsideramos os efeitos derivados dos problemas de agência. Tais premissas simplificam o modelo, pois uma das fontes de incerteza a respeito do procedimento concursal é saber como será realizada a repartição dos ativos da empresa em crise, decisão influenciada pelo comportamento desses agentes ${ }^{203}$.

Adotamos a premissa de que cada jogador analisa vantagens e desvantagens de maneira individual, levando em consideração o comportamento do outro. As estratégias escolhidas pelos jogadores dependem de saber se a empresa é eficiente ou ineficiente, informação assimétrica detida pelo devedor. O modelo indica que nem sempre a decisão eficiente do ponto de vista do interesse público é escolhida pelos jogadores.

O modelo supõe, com base na LREF, que devedor e credores podem adotar as seguintes estratégias: (i) reestruturação privada de dívidas ${ }^{204}$ (art. 167); (ii) falência (arts. 94 e 105); (iii) recuperação, que pode ser judicial (art. 47 e segs.) ou extrajudicial (arts. 161 a 166).

teoria dos jogos. Revista de Direito Mercantil, Industrial, Econômico e Financeiro, Ano XLIV, n. 137, jan./mar. 2005, p. 234.

${ }^{202}$ STANGHELLINI, Lorenzo. Proprietà i controllo dell'impresa in crisi. Rivista delle Società, Ano $49^{\circ} /$ 2004, Set./Out. 2004, fascículo 5 , p. 1079.

${ }^{203}$ WEBB, David C. The importance of incomplete information in explaining the existence of costly bankruptcy. Economica, New Series, Vol. 54, n. 215, Aug. 1987, pp. 284-285.

${ }^{204}$ A doutrina entitula essa forma de reestruturação de workout, que se distingue do prepackaged bankruptcy. O primeiro é espécie de negociação prévia com os credores, assim como o segundo, porém distinguem-se de maneira nítida. No workout evita-se a elaboração do plano de recuperação, enquanto no prepackaged bankruptcy o plano é consequiência natural do acordo. Edward Altman indica que o objetivo essencial do prepackaged bankruptcy é eliminar o problema da minoria nas votações, bem como obter consenso informal com a maioria dos credores para evitar a rejeição futura do plano. O problema é que a estratégia pressupõe que seja dada informação adequada a todos os credores e acionistas, sem que se defina precisamente o que se entende por adequada. Há custos de negociação para encontrar credores dispostos a negociar, desenhar estratégias e alternativas em caso de insucesso da negociação. Depende de haver plano de recuperação viável. (ALTMAN, Edward I. Corporate financial distress and bankruptcy: a complete guide to predicting and avoiding distress and profiting from bankruptcy. $2^{\text {nd }}$ ed., New York: John Wiley, 1993, pp. 101-105) 
É relevante saber se a iniciativa do jogo partirá do devedor ou dos credores, pois o primeiro a atuar tem vantagens estratégicas. $\mathrm{O}$ pedido de falência pode ser requerido por ambos, mas o mesmo não ocorre com a recuperação judicial, um privilégio exclusivo do devedor. Na falência, o pedido feito pelo devedor pode indicar gestão temerária dos negócios, mas o mesmo não pode ser afirmado a respeito da recuperação. $\mathrm{O}$ pedido de falência requerido pelo credor pode indicar tentativa de forçar o devedor a pagá-lo por meio do depósito elisivo e, nesse caso, o credor estaria se utilizando do procedimento concursal como meio mais célere para cobrança. Também é possível desenvolver-se a negociação privada de dívidas, geralmente proposta pelo devedor, mas difícil de ser impulsionada pelos credores, porque estes não são um grupo previamente organizado.

O devedor toma a iniciativa ao optar entre o pedido de autofalência (art. 105) ou a negociação com os credores. Ele opta pela segunda alternativa, porque a primeira não lhe proporciona ganhos. Entretanto, os credores podem requerer a falência da empresa, com base no art. 94, antes de qualquer tentativa de negociação, caso em que o devedor pode pleitear a recuperação no prazo da contestação do pedido (art. 95). Se o devedor não o faz, por inércia ou porque não preenche os requisitos legais previstos no art. 48, o juiz decreta a falência (art. 75).

Se não há pedido de falência, é possível haver negociação com os credores, e o devedor deve escolher entre fazê-la de forma privada (reestruturação de dívidas, art. 167) ou institucionalizá-la por meio do pedido de recuperação judicial (art. 48) ou extrajudicial (arts. 161 a 166). A opção depende da natureza e do prazo de vencimento dos créditos a pagar, e também das alternativas de financiamento disponíveis.

Em um primeiro momento, o devedor da empresa eficiente pode não recorrer à recuperação, evitando a via judicial e preferindo resolver o desequilíbrio financeiro por meio da reestruturação de dívidas ${ }^{205}$. Se a negociação não for bem sucedida, elabora plano de recuperação que prevê pagamento significativo para evitar a falência. Às

\footnotetext{
${ }^{205}$ BAROSSI FILHO, Milton. As assembléias de credores e plano de recuperação de empresas: uma visão da teoria dos jogos. Revista de Direito Mercantil, Industrial, Econômico e Financeiro, Ano XLIV, n. 137, jan./mar. 2005, pp. 236-237.
} 
vezes, prefere evitar a alternativa de negociação privada, se houver sinalização antecipada dos credores de que não haverá acordo.

O devedor da empresa ineficiente deve tentar a negociação direta para adiar a falência, porque a ineficiência da empresa não é solucionada com o acordo. Se não obtiver acordo, deve propor plano de recuperação que preveja pagamento insuficiente dos créditos, visando a barganhar e tentar transferir parte do risco de continuação do negócio aos credores.

Se a negociação privada for bem sucedida, o jogo termina com a distribuição de ganhos acordada entre as partes e a empresa não entra em falência, podendo requerer a recuperação apenas para obter homologação judicial do acordo. Se a negociação for mal sucedida, o devedor precisa institucionalizar a crise requerendo a recuperação, com a desvantagem de ter revelado informações. Como os credores não podem pleitear a recuperação do devedor ou elaborar plano alternativo, restam-lhes apenas duas alternativas: votar o plano de recuperação ou requerer a falência do devedor (art. 94 c/c art. 95). Por isso, uma vez esgotadas as negociações, os credores que não preferem a recuperação irão requerer a falência da empresa.

Caso não haja pedido de falência, o devedor propõe a divisão de ganhos com os credores por meio do plano de recuperação. Os credores têm duas alternativas: aproválo ou rejeitá-lo. $\mathrm{Na}$ recuperação extrajudicial, a aprovação ocorre se não houver objeções ou impugnações, podendo ou não haver homologação pelo juiz. A recuperação judicial, por sua vez, implica em votação favorável nas assembléias de credores (art. 41 c/c 45), jogo seqüencial com informação incompleta, imperfeita e comunicação entre as assembléias.

O jogo termina se os credores aceitam o plano de recuperação. Se há rejeição, o juiz pode decretar a falência (art. 56) ou tentar aprovar o plano de duas maneiras: (i) direta, por meio da decretação do $\operatorname{cramdown}^{206}$ (art. 58, $\S 1^{\circ}$ ); (ii) indireta, por meio da

\footnotetext{
${ }^{206} \mathrm{O}$ uso de anglicismos é reprovável em trabalhos acadêmicos, mas o termo cramdown parece ser intraduzível para o português. A idéia é de aprovação forçada, ou seja, o plano de recuperação é "empurrado" (crammed down) para os credores de forma impositiva.
} 
atribuição de valor positivo aos votos dos ausentes, se a quantidade de votos for suficiente para alcançar a maioria nas votações ${ }^{207}$.

O modelo proposto indica que algumas das alternativas descritas podem não ocorrer. O quadro resumo, apresentado a seguir, indica as soluções mais prováveis, diferenciando a crise temporária da empresa eficiente da crise estrutural, que atinge a empresa ineficiente. O quadro também aponta quando há solução correta para a crise e quando há erro na decisão ${ }^{208}$.

A legenda do quadro de soluções utiliza três cores para discriminar as alternativas: (i) verde: indica a melhor alternativa prevista pelo modelo; (ii) amarelo: representa uma alternativa não-ideal, mas possível de ocorrer; (iii) vermelho: aponta a pior escolha possível, a que traz maiores prejuízos coletivos.

${ }^{207}$ Seção IV.3.1.

${ }^{208} \mathrm{O}$ quadro progride na direção indicada pelas setas. A formulação matemática encontra-se no capítulo V. 


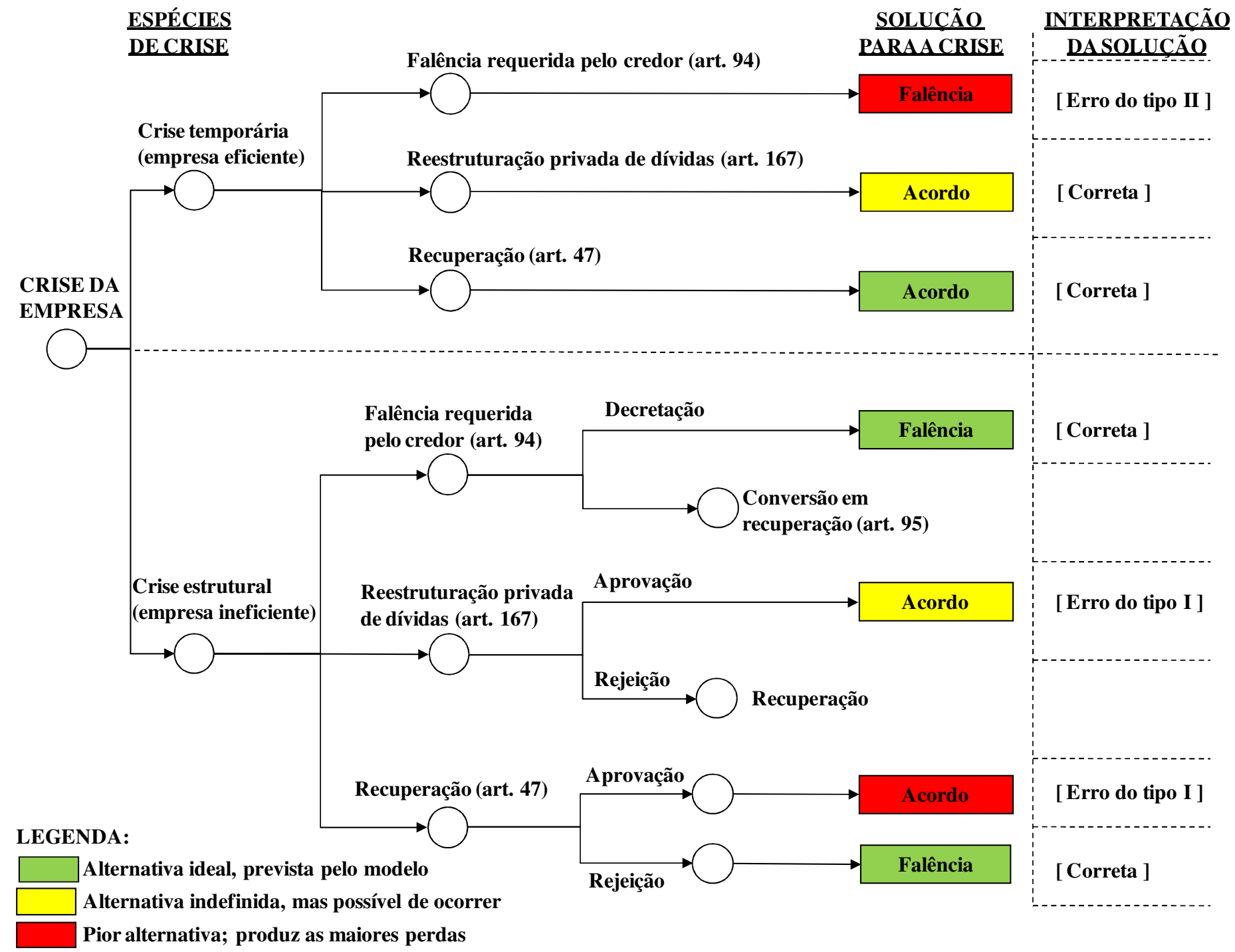




\section{III.3.2. Crise temporária (empresa eficiente).}

A crise temporária é aquela na qual a empresa eficiente apresenta somente problemas de fluxo de caixa no curto prazo. Não há crise irremediável.

As soluções mais prováveis e os principais erros de decisão para a crise da empresa eficiente são apresentados no quadro abaixo.

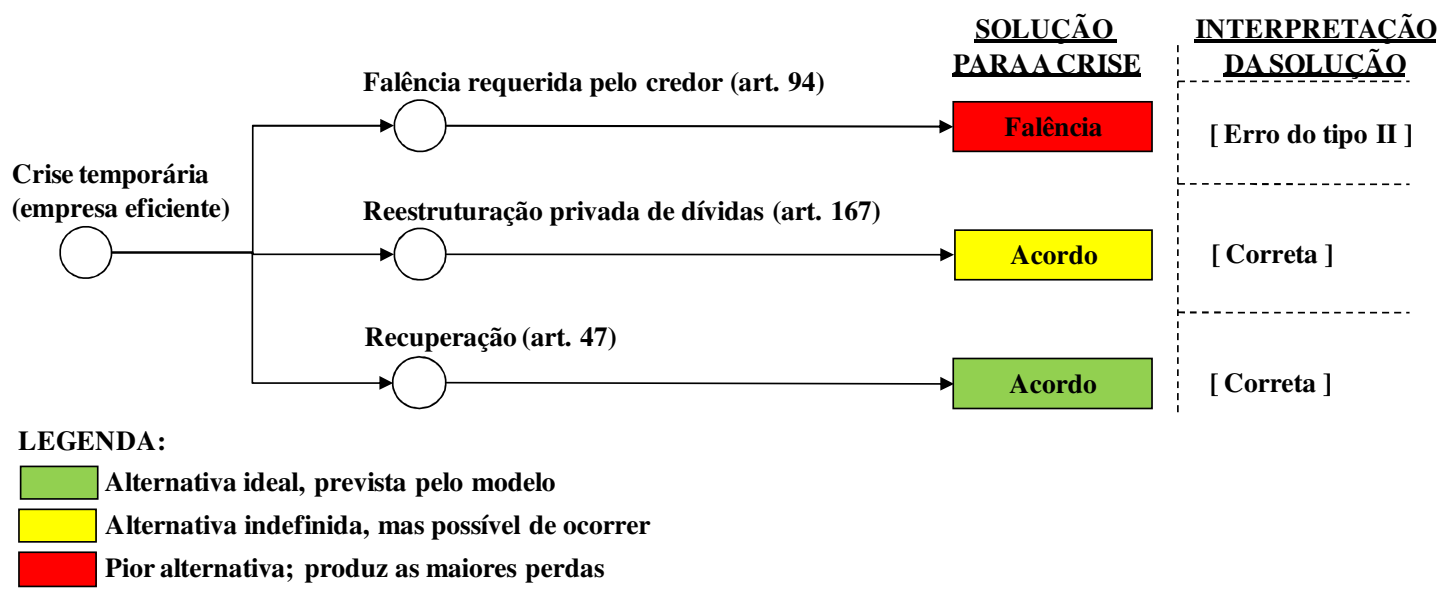

\section{a) Falência}

A empresa eficiente não tem incentivos para requerer a autofalência, uma vez que um negócio não apresenta crise irremediável, mas apenas problemas de fluxo de caixa. O devedor opta pela reestruturação de dívidas ou recuperação. Se escolher a falência, ele pode ser acusado de liquidar negócio próspero, configurando abuso de poder (art. 117, §1º “b”, da LSA ${ }^{209}$ ).

O pedido de falência também pode ser requerido pelo credor (art. 97, IV c/c art. 94) em três situações: (i) não pagamento de dívidas vencidas (art. 94, inciso I); (ii) execução frustrada (art. 94, inciso II); (iii) prática de atos de falência (art. 94, inciso III).

\footnotetext{
${ }^{209}$ Lei das Sociedades Anônimas (LSA), art. 117. "O acionista controlador responde pelos danos causados por atos praticados com abuso de poder. $§ 1^{\circ}$ São modalidades de exercício abusivo de poder: (...) b) promover a liquidação de companhia próspera, ou a transformação, incorporação, fusão ou cisão da companhia, com o fim de obter, para si ou para outrem, vantagem indevida, em prejuízo dos demais acionistas, dos que trabalham na empresa ou dos investidores em valores mobiliários emitidos pela companhia;". A fórmula pode ser aplicada também às sociedades limitadas que adotem a regência supletiva da LSA (art. 1053 do Código Civil), ou mesmo às regidas pelas regras da sociedade simples.
} 
Entretanto, o devedor que deseje evitar a falência pode, no prazo da contestação do pedido, requerer a conversão em recuperação judicial (art. 95) ${ }^{210}$.

Se o credor supõe que terá pouca influência na assembléia que votará o plano de recuperação, ele pode preferir a falência quando esta for mais célere que a recuperação ou quando os ganhos com a falência, descontados os custos, forem maiores do que o valor a ser obtido com a recuperação. Como todas são opções arriscadas, a escolha depende da capacidade de monitorar o devedor e influenciar a decisão assemblear.

Para tomar a decisão, o credor deve utilizar a própria situação financeira como referência, avaliando se está disposto a investir no litígio (falência) ou na negociação (recuperação). Como ele tem menos informações que o devedor a respeito da crise, pode preferir eliminar o risco e requerer a falência do devedor, restando a este a alternativa de requerer ao juiz a conversão em recuperação judicial (art. 95).

A falência da empresa eficiente não é solução ideal, pois ela apresentada apenas desequilíbrio no curto prazo. O pedido de falência, entretanto, pode indicar que a tentativa anterior de reestruturação privada de dívidas foi mal sucedida.

O devedor também pode não tomar nenhuma atitude a respeito da crise e deixar a decisão para os credores. Dessa forma, ganha tempo à frente dos negócios antes que os credores decidam a melhor forma de agir. O devedor inerte deixa de ocupar posição melhor na negociação, transferindo a iniciativa aos credores. Como o concurso de credores é jogo não-cooperativo e a informação assimétrica é detida pelo devedor, este tem vantagens estratégicas ao jogar primeiro. No caso da empresa eficiente, o devedor inerte arrisca-se a ter a falência decretada, produzindo o erro do tipo II. Não é decisão racional.

\section{b) Reestruturacão privada de dívidas}

A reestruturação é, em geral, de iniciativa do devedor (art. 167). São negociadas

${ }^{210}$ LREF, Art. 95. "Dentro do prazo de contestação, o devedor poderá pleitear sua recuperação judicial”. 
alternativas de pagamento e descontos sobre as dívidas.

A negociação privada pode apresentar menores custos que a falência e a recuperação, evitando a interrupção da atividade empresarial e reduzindo prejuízos com a crise. A economia de custos, entretanto, cria incentivos para o devedor induzir os credores a erro, na tentativa de se apropriar dos ganhos adicionais.

A reestruturação tem por objetivo repactuar com credores específicos apenas as dívidas que vencem no curto prazo, pois as dívidas a vencer não podem ser executadas e não servem para justificar o pedido de falência. Por isso, é possível supor que o devedor venha a utilizar o expediente toda vez que houver dívidas vencendo imediatamente. Se a repactuação ocorrer diversas vezes e envolver o mesmo credor, este pode inferir que a empresa passa por crise de maior gravidade e, na negociação seguinte, optar por não aceitar o acordo.

O devedor tem o poder de barganha reduzido com a reestruturação porque revela aos credores, de imediato, informações sobre os negócios. Em caso de fracasso das negociações, os credores terão obtido melhores informações para decidir. A reestruturação também impede que a empresa se utilize dos benefícios legais da recuperação judicial.

A reestruturação, entretanto, pode ser mal sucedida. Mark Roe denomina a causa de insucesso de "efeito de flutuação", que determina que o primeiro credor que rejeitar a oferta tende a se beneficiar em relação aos demais, se puder permanecer por mais tempo aguardando o recebimento dos créditos (permanecer "flutuando"). Ao frustrar a negociação, o credor beneficia-se quando os ganhos para os que não a aceitam são maiores que os custos economizados ao evitar a falência. Reconhecendo o fato, aqueles que querem aceitar a oferta condicionam a aprovação à de todos os demais, porque, se não o fazem, perdem a vantagem ${ }^{211}$.

\footnotetext{
211 "Podemos usar uma metáfora: Imagine cubos de gelo colocados em um cilindro parcialmente preenchido com água. A cada substância é atribuído um valor (ganho), dependendo da capacidade de boiar na superfície do cilindro. Cada cubo terá retorno proporcional ao tamanho e a maioria dos cubos de gelo irá derreter de maneira voluntária. Os demais irão 'flutuar' para a superfície. Uma vez que o ganho depende da capacidade de boiar, os cubos de gelo que demorarem a derreter (holdouts) terão o ganho aumentado se permanecerem
} 
As razões dos credores para não aceitarem a oferta são várias: (i) não desejam consumir tempo e recursos negociando com o devedor; (ii) o valor dos créditos a receber é inferior aos custos de transação; (iii) razões contratuais ou estatutárias que não autorizam a negociação; (iv) comportamento oportunista para aumentar ganhos. A negociação pode não ocorrer mesmo que haja um único credor, em razão de desconfianças a respeito do comportamento do devedor, expectativas desalinhadas ou oportunismo $^{212}$.

Para ser bem sucedida, a reestruturação deve incluir todos os credores com poder de barganha para frustrar a aceitação, reduzir o desalinhamento de expectativas e as desconfianças, atividades que podem ser complexas, dispendiosas e demoradas.

Para tomar a decisão de aceitar ou rejeitar a negociação, é necessário saber se a empresa é eficiente. Como essa é informação assimétrica detida pelo devedor, pode haver empresas ineficientes que consigam se reorganizar e empresas eficientes que não se reestruturem. A existência da etapa de reestruturação beneficia os credores que rejeitam a oferta, pois estarão mais bem informados sobre a situação na etapa seguinte do jogo, na qual terão que votar o plano de recuperação.

Para as empresas eficientes, é vantajoso negociar a reestruturação se o pagamento oferecido aos credores for significativo, pois permite resolver o problema mais depressa. Ainda assim, os credores podem não aceitar a oferta e requerer a falência do devedor pelas razões expostas e também porque não sabem se a empresa é, de fato, eficiente. A opção do credor pela falência é estratégia que visa a evitar perdas futuras, quando ele acredita que a empresa é ineficiente. É decisão equivocada (erro do tipo II), pois a empresa eficiente deve ser recuperada. Entretanto, o credor não leva esse fato em consideração ao tomar a decisão.

É provável que as empresas eficientes não se arrisquem a entrar com pedido de

boiando por mais tempo". (ROE, Mark J. Corporate reorganization and bankruptcy - legal and financial materials. University Casebook Series, New York: Foundation Press, 2000, pp. 405-409) (tradução livre)

${ }^{212}$ Ibid, pp. 410-412. 
recuperação, se for possível negociar a reestruturação privada, mas não significa que as empresas ineficientes não tentarão usar a opção para extrair renda dos credores. Não se pode afirmar que somente empresas eficientes utilizarão a reestruturação, porque esta também beneficia as empresas ineficientes.

Os administradores de empresas eficientes preferem a reestruturação privada ou o plano de recuperação com oferta de pagamento suficiente, uma vez que requerer a liquidação é decisão irracional e pode implicar em responsabilização por danos causados à sociedade (LSA, art. 117, §1, “b”).

Com base no modelo proposto, é possível sustentar que a empresa eficiente pode não recorrer à recuperação, preferindo resolver o desequilíbrio financeiro pela via da reestruturação de dívidas ${ }^{213}$. Quanto mais rápido ocorrer a negociação, maior o retorno. Se os credores tiverem dúvidas sobre o futuro da empresa, podem preferir a falência para evitar perdas adicionais.

A negociação privada também pode ser proposta pelos credores, mas é de improvável ocorrência visto que: (i) eles não conhecem a situação da empresa tão bem quanto o devedor e terão dificuldade em elaborar acordo factível; (ii) é incomum haver relacionamento prévio entre os credores, sendo atividade complexa reuni-los fora do procedimento concursal; (iii) a negociação individual com o devedor pode configurar ato de falência se a empresa estiver na iminência de quebra (art. 94, III); (iv) se o acordo não vincular todos os credores, pode não evitar o pedido de falência ou a futura rejeição do plano de recuperação.

O credor individual avalia se há vantagem em se antecipar aos demais credores e estabelecer negociações com o devedor. É situação que a teoria dos jogos denomina de “corrida para ser o primeiro" ${ }^{214}$, acordo no qual há alienação de ativos para pagar o

\footnotetext{
${ }^{213} \mathrm{Na}$ mesma linha: BAROSSI FILHO, Milton. As assembléias de credores e plano de recuperação de empresas: uma visão da teoria dos jogos. Revista de Direito Mercantil, Industrial, Econômico e Financeiro, Ano XLIV, n. 137, jan./mar. 2005, pp. 236-237.

${ }^{214}$ WHITE, Michelle J. Corporate bankruptcy. Disponível em: <http://www.ssrn.com>. Acesso em: 16.abr.2006, pp. 5-6; WEBB, David C. An Economic Evaluation of Insolvency Procedures in the United Kingdom: Does the 1986 Insolvency Act Satisfy the Creditors' Bargain? Oxford Economic Papers, New Series, Vol. 43, N. 1, Jan. 1991, pp. 139-157.
} 
credor individual, causando prejuízos aos demais credores. Se cada interessado adotar a estratégia, a corrida toma a forma do dilema do prisioneiro que leva à liquidação precipitada de ativos do devedor.

Suponha que a empresa tenha ativos no valor total de 100, e passivo de 180, distribuído entre os credores A e B no valor de, respectivamente, 100 e 80 . Se A corre para ser o primeiro, recebe 100 e B não recebe nada. Se B corre, recebe 80 , e A recebe 20. Se ambos correm, imagine que A recebe 60 e B recebe 40 . Por fim, se ambos concordam em não correr, suponha que os ativos valham 144, ao invés de 100, porque não foram dilapidados. Neste caso, se ambos concordam em dividir os ganhos na proporção do valor de face dos créditos, o credor A recebe 80 e B obtém $64^{215}$. O dilema do prisioneiro, representado na forma matricial, é:

\begin{tabular}{|l|l|l|}
\cline { 2 - 3 } \multicolumn{1}{c|}{} & B não corre & B corre \\
\hline A não corre & $(80,64)$ & $(20,80)$ \\
\hline A corre & $(100,0)$ & $(60,40)^{216}$ \\
\hline
\end{tabular}

Os credores A e B receberiam valor maior se ambos não corressem $(80,64)$, mas a solução para o jogo ${ }^{217}$ ocorre quando ambos correm $(60,40)$. Eles escolhem a solução não-cooperativa porque disputam o recebimento dos créditos e são incapazes de chegar a um acordo para divisão das perdas.

Um dos objetivos do procedimento concursal é evitar a corrida dos credores e a dilapidação de ativos. Os credores podem ameaçar a empresa com a falência para receber os créditos por meio do depósito elisivo (art. 98). O devedor que quiser adiar a falência pode negociar com certos credores e pagá-los sem incorrer em fraude. A solução, entretanto, tende a dilapidar os ativos da empresa, causando prejuízos à coletividade de credores.

\footnotetext{
${ }^{215} \mathrm{O}$ credor A recebe $80=100 / 180 \times 144 . \mathrm{O}$ credor B recebe $64=80 / 180 \times 144$.

${ }^{216} \mathrm{O}$ jogo apresentado é simultâneo e de informação completa. Os valores entre parênteses referem-se, respectivamente, aos ganhos para os credores A e B em cada estratégia.

${ }^{217}$ A solução é o equilíbrio de Nash, a melhor resposta para o problema, consideradas as estratégias adotadas pelos demais jogadores. (FIANI, Ronaldo. Teoria dos jogos. $2^{\mathrm{a}}$ ed., São Paulo: Campus, 2006, pp. 93-94; 9899; GINTIS, Herbert. Game theory evolving - A problem-centered introduction to modeling strategic interaction. Princeton: Princeton University Press, 2000, p. 13).
} 
É possível, por iniciativa dos credores, haver negociação individual antes da instauração do procedimento concursal, mas tal opção tende a dilapidar os ativos. Entretanto, a negociação coletiva é de difícil operacionalização, uma vez que os credores não são grupo homogêneo e organizado ${ }^{218}$. Além disso, o termo legal da falência (art. 99, $\mathrm{II}^{219}$ ), que é de até noventa dias, pode ser insuficiente para identificar e coibir abusos; o devedor é capaz de perceber a gravidade da crise muito antes do prazo legal, mas o mesmo não ocorre para a maioria dos credores.

A introdução da etapa de reestruturação de dívidas não evita a ocorrência de erros, mas pode permitir reduzir custos. Os ganhos com tal redução, entretanto, tendem a ser apropriados pelo devedor. É uma solução de difícil operacionalização, tende a ter prazo menor que o procedimento judicial e pode resolver o problema de forma parcial.

\section{c) Recuperacão}

A recuperação pode ser judicial ou extrajudicial.

Na recuperação extrajudicial, a decisão dos credores pode ser favorável ou desfavorável ao plano. A primeira ocorre por meio de adesão do credor individual à proposta, e a segunda por meio da objeção, não existindo votação em assembléia em nenhum dos casos (arts. 161 a 166). As dificuldades de aprovação e os motivos de rejeição assemelham-se aos descritos para a alternativa de reestruturação de dívidas, porém a recuperação extrajudicial abrange somente os credores quirografários e estabelece critérios específicos para pagamento das dívidas. Por isso, os demais credores, não abrangidos pelo plano, podem requerer a falência do devedor.

Na recuperação judicial haverá votação do plano de recuperação em assembléia e a decisão será tomada pelos credores. O devedor pode, no entanto, vetar alterações

\footnotetext{
${ }^{218}$ STANGHELLINI, Lorenzo. Proprietà i controllo dell'impresa in crisi. Rivista delle Società, Ano $49^{\circ} /$ 2004, Set./Out. 2004, fascículo 5º , p. 1079.

${ }^{219}$ LREF, art. 99. "A sentença que decretar a falência do devedor, dentre outras determinações: (...) II fixará o termo legal da falência, sem poder retrotraí-lo por mais de 90 (noventa) dias contados do pedido de falência, do pedido de recuperação judicial ou do $1^{\circ}$ (primeiro) protesto por falta de pagamento, excluindo-se, para essa finalidade, os protestos que tenham sido cancelados;" (...).
} 
propostas pelos credores se acreditar que o juiz os obrigará a aceitar o acordo original ${ }^{220}$.

Os administradores das empresas eficientes têm incentivos para requerer a recuperação porque são mantidos na condução dos negócios durante a crise. O objetivo é maximizar o valor dos ativos, elaborando plano que tenha possibilidades reais de aceitação pelos credores. Ainda assim, os administradores têm incentivos para adiar a apresentação do plano, pois a medida corrói o valor dos créditos e aumenta o desconto para pagamento das dívidas.

$\mathrm{Na}$ recuperação, o devedor pode propor pagamento significativo do valor dos créditos. O pedido vincula o devedor e, após a concessão, não pode haver desistência sem anuência dos credores (art. 52, $\S 4^{\circ}$ ). A norma evita que o devedor se utilize impunemente do sistema concursal para obter concessões dos credores, evitando comportamentos oportunistas. Segundo Rachel Sztajn, o devedor deverá justificar o pedido de desistência com base em fatos novos ou alterações das condições que permitam concluir que a melhora autoriza o cancelamento da recuperação, ou que a piora indica que se deva requerer a falência ${ }^{221}$.

Os credores avaliam a viabilidade do plano pela forma como o devedor propõe pagar as dívidas. Para eles, a proposta de pagamento representa sinalização sobre as reais intenções do devedor, orientando a decisão de aprovação ou rejeição da oferta. Rachel Sztajn entende que, para servir de fundamento à recuperação, o plano deve ser exeqüível, isto é, conter a possibilidade concreta de pagamento das obrigações ajustadas, permitindo a continuidade das operações ${ }^{222}$.

A lei não obriga que o devedor pague primeiro os credores com garantia, porque ele pode propor a ordem de pagamento que achar conveniente. Para os credores nãotrabalhistas (classes II e III), a prioridade depende do valor dos créditos, relacionamento prévio e necessidade de realizar negócios futuros com o devedor. É

\footnotetext{
${ }^{220}$ Seção IV.3.1.

${ }^{221}$ SZTAJN, Rachel. Comentários. In SOUZA JR, Francisco Satiro de; PITOMBO, Antonio Sérgio A de Moraes (coord.). Comentários à lei de recuperação de empresas e falência. São Paulo: Revista dos Tribunais, 2005, pp. 262-263.

${ }^{222}$ Ibid, p. 227.
} 
provável que os credores menos privilegiados (classe III) recebam pequena parcela do valor das dívidas. Para os trabalhistas, a situação é diversa, pois a LREF tutela o pagamento tanto na recuperação quanto na falência. Eles recebem algum valor por força dos arts. 54, 83 e 151 da lei ${ }^{223}$. Como votam por cabeça, não importando o valor dos créditos, o devedor precisa pagar parcela maior aos trabalhadores que detêm créditos de valor mais baixo, alcançando combinação de pagamentos que garanta a maioria simples de cabeças, aprovando o plano com o menor desembolso possível ${ }^{224}$.

A empresa eficiente tende a demonstrar que haverá retorno futuro com a recuperação, pois o valor do negócio em funcionamento é maior que o valor de liquidação ${ }^{225}$. A decisão de liquidação (erro do tipo II) tende a ocorrer com menor freqüência porque há razoáveis maneiras de demonstrar que o negócio não é insolvente, apenas apresenta desequilíbrio de fluxo de caixa. A demonstração pode ser feita, por exemplo, por meio de análise do balanço, demonstrativos financeiros, estimativa do valor de mercado da empresa, análise de viabilidade dos projetos de investimento.

A empresa deve optar por plano de recuperação que preveja pagamento significativo aos credores, uma vez que não é racional arriscar-se a ter a falência de negócio próspero decretada. Assim como para a empresa ineficiente, há incentivos para adiar a apresentação do plano, porque a atitude aumenta a possibilidade de obter maiores descontos para as dívidas. O problema é que tal estratégia é arriscada: o credor pode supor que a empresa é ineficiente e rejeitar o plano, situação na qual o juiz é obrigado a decretar a falência (art. $\left.56, \S 4^{\circ}\right)$.

\footnotetext{
223 “Art. 54. O plano de recuperação judicial não poderá prever prazo superior a 1 (um) ano para pagamento dos créditos derivados da legislação do trabalho ou decorrentes de acidentes de trabalho vencidos até a data do pedido de recuperação judicial. Parágrafo único. O plano não poderá, ainda, prever prazo superior a 30 (trinta) dias para o pagamento, até o limite de 5 (cinco) salários-mínimos por trabalhador, dos créditos de natureza estritamente salarial vencidos nos 3 (três) meses anteriores ao pedido de recuperação judicial".

"Art. 83. A classificação dos créditos na falência obedece à seguinte ordem: I - os créditos derivados da legislação do trabalho, limitados a 150 (cento e cinqüenta) salários-mínimos por credor, e os decorrentes de acidentes de trabalho; II - créditos com garantia real até o limite do valor do bem gravado; (...)"

"Art. 151. Os créditos trabalhistas de natureza estritamente salarial vencidos nos 3 (três) meses anteriores à decretação da falência, até o limite de 5 (cinco) salários-mínimos por trabalhador, serão pagos tão logo haja disponibilidade em caixa".

${ }^{224}$ Por exemplo, se há três credores trabalhistas, com valores a receber de 4,10 e 20 reais, o devedor tende a optar por pagar parcela maior aos dois primeiros, pois consegue a aprovação destes na votação desembolsando valor menor que se optar por pagar maior valor ao terceiro credor.

${ }^{225}$ Ver discussão a respeito do "best-interest-of-creditors test" no capítulo IV.
} 
Quando a opção for pela recuperação, a decisão final a respeito do destino da empresa será tomada pelos credores reunidos em assembléia. Se eles aceitam a proposta, o plano é aprovado e o jogo termina. Se rejeitam a oferta, a falência é decretada (art. 56, $\$ 4^{\circ} \mathrm{c} / \mathrm{c}$ art. 73 , III) ${ }^{226}$ e o produto da liquidação rateado, de acordo com a ordem de pagamento (art. 149) ${ }^{227}$, ou então haverá decisão do juiz obrigando-os a aceitar o plano (cramdown, art. 58). Dependendo do valor oferecido pelo devedor, os credores podem preferir não se arriscar e rejeitar a oferta, requerendo desde logo a falência do devedor.

A votação do plano deve ocorrer nas três assembléias (art. 41), uma para cada classe de credores: trabalhistas e por acidente do trabalho (classe I); com garantia real (classe II); com garantia menor ou sem garantia (classe III). A aprovação se dá por duplo critério para os credores não-trabalhistas: maioria do valor dos créditos cumulada com maioria simples dos presentes (art. $41 \mathrm{c} / \mathrm{c}$ art. 45) ${ }^{228}$. Para os trabalhistas (classe I), basta a obtenção de voto favorável da maioria simples dos presentes, não importando o valor dos créditos de cada um. As disposições legais tornam o processo de votação instável e complexo, especialmente na classe III $^{229}$.

Muitas vezes, a decisão coletiva não representa o conjunto de preferências individuais, pois estas são influenciadas pela ordem das votações. O problema é conhecido como Paradoxo das Votações, ou Paradoxo de Condorcet ${ }^{230}$. Na LREF, as

${ }^{226}$ LREF, Art. 56, §4 "Rejeitado o plano de recuperação pela assembléia-geral de credores, o juiz decretará a falência do devedor".

“Art. 73. O juiz decretará a falência durante o processo de recuperação judicial: (...) III - quando houver sido rejeitado o plano de recuperação, nos termos do $\S 4^{\circ}$ do art. 56 desta Lei”; (...)

${ }^{227}$ LREF, Art. 149. "Realizadas as restituições, pagos os créditos extraconcursais, na forma do art. 84 desta Lei, e consolidado o quadro-geral de credores, as importâncias recebidas com a realização do ativo serão destinadas ao pagamento dos credores, atendendo à classificação prevista no art. 83 desta Lei, respeitados os demais dispositivos desta Lei e as decisões judiciais que determinam reserva de importâncias".

${ }^{228}$ LREF, Art. 45. "Nas deliberações sobre o plano de recuperação judicial, todas as classes de credores referidas no art. 41 desta Lei deverão aprovar a proposta. $\S 1^{\circ} \mathrm{Em}$ cada uma das classes referidas nos incisos II e III do art. 41 desta Lei, a proposta deverá ser aprovada por credores que representem mais da metade do valor total dos créditos presentes à assembléia e, cumulativamente, pela maioria simples dos credores presentes. $\S 2^{\circ} \mathrm{Na}$ classe prevista no inciso I do art. 41 desta Lei, a proposta deverá ser aprovada pela maioria simples dos credores presentes, independentemente do valor de seu crédito".

${ }^{229}$ Na mesma linha, Rachel Sztajn entende que o processo de votação é mais instável na classe III. (SZTAJN, Rachel. Notas sobre as assembléias de credores na lei de recuperação de empresas. Revista de Direito Mercantil, Industrial, Econômico e Financeiro, Ano XLIV, n. 138, abr./jun. 2005, pp. 59-60)

${ }^{230}$ O Paradoxo das Votações, ou Paradoxo de Condorcet, é importante limitação da teoria da escolha racional. O paradoxo demonstra que as preferências individuais podem não refletir as preferências do grupo. Como os agentes têm preferências relativas, ou seja, dependem de comparação entre as alternativas 
três assembléias são realizadas de forma seqüencial porque devem ser presididas pelo administrador judicial (art. 37) ${ }^{231}$. Se forem realizadas na ordem em que as classes estão dispostas na lei (art. 41), pode-se supor que os trabalhadores votam primeiro (classe I), seguidos pelos credores com garantia real (classe II) e demais (classe III).

A figura abaixo representa tal esquema de votação. O nó $\mathrm{C} 1$ representa a votação dos credores trabalhistas; C2 a decisão dos credores com garantia real; C3 a escolha dos demais credores.

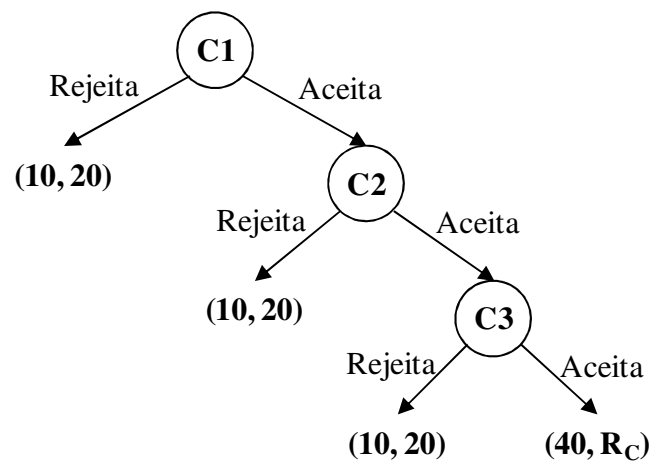

Essa sequiência de votações prejudica a classe dos trabalhadores. Nessa classe, há grande probabilidade de se votar a favor do plano, atitude que permite manter os empregos. Como o plano deve ser aprovado pelas três classes, o credor com garantia real terá vantagens estratégicas porque seu voto é decisivo. Não se pode afirmar que o credor com garantia real (classe II) tende a aprovar o plano, já que pode preferir requerer a falência para receber o valor correspondente à garantia. A vantagem aumenta ainda mais se os credores sem garantia (classe III) votarem "seguindo o líder". Nesse caso, os credores com garantia que desejam a falência do devedor podem votar contra o plano, acompanhados dos credores sem garantia. Além disso, o credor com garantia também pode votar na classe III pelo saldo dos créditos que ultrapassarem o valor do bem dado em garantia. Como as assembléias são seqüenciais e existe comunicação de informações, o credor sabe como a assembléia anterior deliberou e

apresentadas, quando a ordem das votações é alterada as escolhas individuais podem mudar, alterando o resultado da votação obtido para o grupo. (FIANI, Ronaldo. Teoria dos jogos. $2^{\mathrm{a}}$ ed., São Paulo: Campus, 2006, pp. 27-29)

${ }^{231}$ LREF, art. 37. "A assembléia será presidida pelo administrador judicial, que designará 1 (um) secretário dentre os credores presentes". 
pode tentar controlar a votação seguinte. Assim, o voto dos trabalhadores não influencia de forma significativa o resultado, pois a aprovação do plano depende do voto dos demais credores.

Explicamos, a seguir, as principais estratégias de cada classe.

\section{Credor com garantia real (classe II) ${ }^{232}$}

Para os credores com garantia real, se o plano for rejeitado, recebem o valor de liquidação ou de mercado da garantia ${ }^{233}$. Por isso, no plano, negociam com o devedor a taxa de retorno que corresponde a esse valor. Podem sinalizar que não aprovarão o plano ${ }^{234}$ ou negociar com o devedor um valor a receber, apenas para não prolongar as tratativas, se a demora levar à desvalorização dos bens dados em garantia. O retorno deve ser maior ou igual ao valor de mercado dos bens garantidores, descontados os custos de transação. A negociação pode ser realizada de forma privada e os efeitos reproduzidos no plano e na assembléia, desde que haja cuidado para que o plano não altere as condições do crédito, pois, nesse caso, o credor seria impedido de votar (art.

\footnotetext{
${ }^{232}$ LREF, Art. 41, II.

${ }^{233}$ LREF, Art. $50, \S 1^{\circ}$ (...) "Na alienação de bem objeto de garantia real, a supressão da garantia ou sua substituição somente serão admitidas mediante aprovação expressa do credor titular da respectiva garantia". Art. 59. "O plano de recuperação judicial implica novação dos créditos anteriores ao pedido, e obriga o devedor e todos os credores a ele sujeitos, sem prejuízo das garantias, observado o disposto no $\S 1^{\circ}$ do art. 50 desta Lei".

Art. 61. "Proferida a decisão prevista no art. 58 desta Lei, o devedor permanecerá em recuperação judicial até que se cumpram todas as obrigações previstas no plano que se vencerem até 2 (dois) anos depois da concessão da recuperação judicial. $\$ 1^{\circ}$ Durante o período estabelecido no caput deste artigo, o descumprimento de qualquer obrigação prevista no plano acarretará a convolação da recuperação em falência, nos termos do art. 73 desta Lei. $\$ 2^{\circ}$ Decretada a falência, os credores terão reconstituídos seus direitos e garantias nas condições originalmente contratadas, deduzidos os valores eventualmente pagos e ressalvados os atos validamente praticados no âmbito da recuperação judicial".

Art. 83. "A classificação dos créditos na falência obedece à seguinte ordem: (...) II - créditos com garantia real até o limite do valor do bem gravado; (...) $\$ 1^{\circ}$ Para os fins do inciso II do caput deste artigo, será considerado como valor do bem objeto de garantia real a importância efetivamente arrecadada com sua venda, ou, no caso de alienação em bloco, o valor de avaliação do bem individualmente considerado".

${ }^{234}$ Por exemplo, o estudo de viabilidade econômica (art. 53, II) e o laudo de avaliação de bens ou ativos (art. 53, III) são partes integrantes do plano e seguem as mesmas regras de aprovação. A rejeição do estudo ou do laudo importa em rejeição do plano, com conseqüente convolação da recuperação em falência. A impugnação pode ser estratégia adotada para negociação com o devedor e indicar tendência de aprovação ou rejeição do plano. (SZTAJN, Rachel. Comentários. In SOUZA JR, Francisco Satiro de; PITOMBO, Antonio Sérgio A de Moraes (coord.). Comentários à lei de recuperação de empresas e falência. São Paulo: Revista dos Tribunais, 2005, p. 267)
} 
$\left.45, \S 3^{\circ}\right)^{235}$.

A LREF permite que o credor vote também com os da classe III pelo valor do crédito que superar o valor do bem dado em garantia (art. $41, \S 2^{\circ}$ ) ${ }^{236}$. Se tiver créditos em valor suficiente para controlar a votação nas duas classes, poderá garantir a aprovação ou rejeição do plano $^{237}$. Se existir mercado secundário para os créditos, o credor poderá adquiri-los de terceiros para garantir o controle das duas votações, uma vez que não há impeditivo legal a tal atitude ${ }^{238}$.

A estratégia é mitigada pela regra do art. $45, \S 1^{\circ}$ da LREF que indica que a decisão deve ser aprovada por maioria dos créditos, cumulada com a maioria simples dos presentes. Como essa classe tende a ter número menor de integrantes, a regra legal pode ser insuficiente para impedir a manipulação das votações. Pode haver casos em que estejam em número insuficiente para alcançar a maioria simples, necessitando formar coalizão com outros credores para atingir o quorum legal.

Esses credores estão em posição privilegiada porque têm melhores condições de controlar a votação; estão mais bem informados e têm capacidade de identificar a real situação da empresa. Preferem negociar a reestruturação com o devedor e, em caso de insucesso, aceitam plano com pagamento significativo, ao menos igual ao valor do bem

\footnotetext{
${ }^{235}$ LREF, Art. $45 \S 3^{\circ}$. "O credor não terá direito a voto e não será considerado para fins de verificação de quorum de deliberação se o plano de recuperação judicial não alterar o valor ou as condições originais de pagamento de seu crédito".

${ }^{236}$ LREF, Art. $41 . \$ 2^{\circ}$ "Os titulares de créditos com garantia real votam com a classe prevista no inciso II do caput deste artigo até o limite do valor do bem gravado e com a classe prevista no inciso III do caput deste artigo pelo restante do valor de seu crédito".

${ }^{237}$ Milton Barossi Filho entende que basta haver formação de subgrupo com capacidade de reprodução em mais de uma assembléia, constituído por dois terços do valor total dos créditos e com capacidade para convencer os demais credores. (BAROSSI FILHO, Milton. As assembléias de credores e plano de recuperação de empresas: uma visão da teoria dos jogos. Revista de Direito Mercantil, Industrial, Econômico e Financeiro, Ano XLIV, n. 137, jan./mar. 2005, p. 235). Rachel Sztajn entende que o credor que vota em duas classes pode influenciar decisivamente a aprovação ou rejeição do plano, se o valor do seu crédito for significativo em ambas. (SZTAJN, Rachel. Notas sobre as assembléias de credores na lei de recuperação de empresas. Revista de Direito Mercantil, Industrial, Econômico e Financeiro, Ano XLIV, n. 138, abr./jun. 2005, p. 59; Comentários. In SOUZA JR, Francisco Satiro de; PITOMBO, Antonio Sérgio A de Moraes (coord.). Comentários à lei de recuperação de empresas e falência. São Paulo: Revista dos Tribunais, 2005, p. 227)

${ }^{238}$ Criticando a possibilidade de cessão de créditos, Edward Altman indica que credores com privilégios que desejem rejeitar o plano de recuperação poderiam comprar créditos sem garantia para influir na votação da outra classe. (ALTMAN, Edward I. Corporate financial distress and bankruptcy: a complete guide to predicting and avoiding distress and profiting from bankruptcy. $2^{\text {nd }}$ ed., New York: John Wiley, 1993, p. 85)
} 
dado em garantia. Entretanto, os credores podem preferir evitar a desvalorização da garantia, requerendo desde logo a falência, se for solução mais célere para receber o valor devido. Em caso de opção pela recuperação da empresa, concedem descontos sobre os créditos se o prazo do procedimento for abreviado e o plano lhes for favorável. Esses credores tentarão controlar a votação, obrigando o devedor a oferecer retorno suficiente para aprovar o plano. A aprovação ou rejeição depende de saber se a garantia pode vir a se deteriorar, e quanto tempo decorrerá para que o valor correspondente ao bem garantidor lhes seja entregue.

Pode haver outros impedimentos à aprovação do plano, como por exemplo, restrições estatutárias ou legais para transigir sobre créditos, ou se o credor deseja demonstrar ao restante do mercado que não negocia com devedores que não cumprem compromissos assumidos.

O governo não foi modelado como agente independente, mas seu comportamento pode induzir ou acelerar o estado de falência ${ }^{239}$. Esse credor é relevante pelas seguintes razões: (i) as dívidas fiscais e previdenciárias costumam representar grande parte dos débitos da empresa em crise; (ii) não costuma transigir sobre as dívidas; (iii) tem privilégios legais na falência, mas não é atingido pela recuperação; (iv) prefere receber, rapidamente, os créditos vencidos, atitude incompatível com a preservação da empresa viável; (v) tende a vetar alguns dos meios de recuperação escolhidos pelo devedor (art. 50), em especial, aqueles que implicam em alienação de ativos para pagar os demais credores.

Além disso, o art. 57 da LREF e o art. 191-A do Código Tributário Nacional (CTN) determinam a quitação prévia de todos os tributos para que a recuperação possa ser concedida, exigência que, por ser considerada abusiva, tem sido dispensada pelos juízes sob dois argumentos: (i) o crédito não está sujeito à recuperação (art. $6^{\circ}, \S 7^{\circ}$ ), fazendo com que o credor fiscal assuma a posição de terceiro prejudicado, e não de participante; (ii) ainda não foi regulamentado o art. 68 da LREF que prevê a edição de

\footnotetext{
${ }^{239}$ Fabio Comparato preleciona que: “(...) se o soerguimento da grande empresa combalida é de interesse público, por razões de ordem social e econômica, é inevitável o sacrifício relativo do Fisco (...)”. (COMPARATO, Fabio K. Aspectos jurídicos da macro-empresa. Revista dos Tribunais, 1970, p. 119)
} 
lei específica para parcelamento do crédito tributário aos devedores em recuperação judicial $^{240}$.

\section{Credor sem garantia ou com garantia menor (classe III) ${ }^{241}$}

Tal classe de credores é bastante heterogênea, composta por credores quirografários, detentores de privilégio geral ou especial e credores subordinados. A obtenção de maioria nessa classe é procedimento instável e complexo.

Em caso de aprovação do plano, são esses credores que assumem a maior parcela de riscos com a continuidade dos negócios. É provável que recebam montante pouco significativo dos créditos tanto na recuperação quanto na falência. Em geral, são surpreendidos pela crise, pois não estão bem informados sobre a situação da empresa.

Supondo a classe homogênea, os credores podem sinalizar que irão tentar impedir a aprovação do plano visando a negociar a taxa de retorno para o crédito. Se a empresa for liquidada, os credores pouco ou nada receberão, pois têm baixa prioridade na ordem de pagamento (art. $149 \mathrm{c} / \mathrm{c}$ art. 83). O retorno para compensar a aprovação deverá ser maior ou igual ao valor de liquidação. Por isso, esses credores têm interesse em alongar o prazo do procedimento de recuperação porque, com tal atitude, podem tentar extrair renda dos demais credores ou do devedor. Eles negociam com o devedor o recebimento de algum valor, em troca de não impedir que o atraso no procedimento acarrete a desvalorização dos ativos e das garantias.

\footnotetext{
${ }^{240}$ Ver, por exemplo: Câmara Especial de Falências e Recuperações Judiciais; Agravo de Instrumento ${ }^{\circ}$ 455.187.4/0-00, $1^{\text {a }}$ Vara Cível de Ribeirão Preto; Agravante: União Federal; Agravado: Indústria de Produtos Alimentícios Cory Ltda. - em recuperação judicial: "Agravo de Instrumento. Recuperação Judicial. Aprovação do plano de recuperação judicial. Decisão que concede a recuperação judicial, com dispensa da apresentação das certidões negativas de débitos tributários, exigidas pelo artigo 57, da Lei $\mathrm{n}^{\circ}$ 11.101/2005 e artigo 191-A, do CTN. Recurso interposto pela União Federal. Reconhecimento da legitimidade e interesse em recorrer, como 'terceiro prejudicado', mesmo não estando os créditos tributários sujeitos à habilitação na recuperação judicial. Exigência do artigo 57 da LRF que configura antinomia jurídica com outras normas que integram a Lei $\mathrm{n}^{\circ}$ 11.101/2005, em especial, o artigo 47. Abusividade da exigência, enquanto não for cumprido o artigo 68 da nova Lei, que prevê a edição de lei específica sobre o parcelamento do crédito tributário para devedores em recuperação judicial. Dispensa da juntada das certidões negativas ou das positivas com efeito de negativas mantida. Agravo desprovido."

${ }^{241}$ LREF, Art. 41. "A assembléia-geral será composta pelas seguintes classes de credores: (...) III - titulares de créditos quirografários, com privilégio especial, com privilégio geral ou subordinados."
} 
Os credores podem adotar a estratégia de "seguir o líder", votando da mesma forma que os credores com garantia real (classe II), imaginando aproveitarem-se do conhecimento destes a respeito da crise. Eles não têm meios para compelir o devedor a aumentar a proposta de pagamento de seus créditos no plano. A melhor estratégia de que dispõem é inviabilizar o término do procedimento pelo maior tempo possível, provocando "atrasos estratégicos" e impondo custos aos demais credores, pois a maior parte do prejuízo decorrente da demora adicional não é suportada por eles.

Barry Adler propõe solução para equilibrar as negociações, assumindo a premissa de que a empresa em crise se beneficia com a aplicação de descontos sobre os créditos e que é possível a adjudicação de ativos aos credores com garantia real. Recomenda jogo do tipo "pegar ou largar" que permite aos credores sem garantia controlar o procedimento concursal e oferecer aos credores com garantia real o pagamento imediato de valor inferior ao bem garantidor, apropriando-se da diferenç $\mathrm{a}^{242}$. A solução é viável se os credores sem garantia controlarem o procedimento, alterando ou propondo novo plano, opção não prevista nas regras da LREF. A hipótese, entretanto, demonstra que a desconsideração do interesse dos credores sem garantia aumenta os riscos de reprovação do plano ou de haver demora excessiva do término do procedimento, agravando ainda mais os prejuízos coletivos.

\section{Credor trabalhista e por acidente do trabalho (classe I) ${ }^{243}$}

Tais credores votam por cabeça, não importando o valor dos créditos que detêm $\left(\text { art. } 45, \S \S 1^{\circ} \text { e } 2^{\circ}\right)^{244}$. São os primeiros a votar e a lei não permite que exerçam o direito em mais de uma assembléia. São credores aversos ao risco e protegidos pela legislação trabalhista. A votação depende da presença em assembléia, revelando o problema do absenteísmo, que é de difícil solução.

\footnotetext{
${ }^{242}$ ADLER, Barry E. Game-theoretic bankruptcy valuation. New York University - Law and Economics Research Paper Series n. 07-03, January 2007. Disponível em: <http://www.ssrn.com>. Acesso em: 29.01.2007, p. 11.

${ }^{243}$ LREF, Art. 41, I.

${ }^{244}$ LREF, Art. 45. "Nas deliberações sobre o plano de recuperação judicial, todas as classes de credores referidas no art. 41 desta Lei deverão aprovar a proposta. $\S 1^{\circ}$ Os titulares de créditos derivados da legislação do trabalho votam com a classe prevista no inciso I do caput deste artigo com o total de seu crédito, independentemente do valor. $\S 2^{\circ} \mathrm{Na}$ classe prevista no inciso I do art. 41 desta Lei, a proposta deverá ser aprovada pela maioria simples dos credores presentes, independentemente do valor de seu crédito".
} 
A aprovação do plano depende de o devedor avaliar subclasses de trabalhadores (operários, gerentes) e o interesse de cada uma na votação. As subclasses, agrupamento em categorias profissionais (gerentes, subalternos, técnicos, administrativos) ou natureza dos créditos (trabalhistas, por acidente de trabalho), podem permitir diferenciar subconjuntos de credores com comportamentos distintos. É necessário calcular o valor total dos créditos e a quantidade de cabeças, em cada subclasse, a fim de estimar o valor necessário para obter a maioria. O conceito de subclasse não é previsto na LREF: trata-se de mera técnica de otimização de pagamento, que pode ser usada pelo devedor.

O grau de empregabilidade dos trabalhadores afeta a votação ${ }^{245}$. Como a lei indica que esses créditos devem ser pagos com prioridade, os empregados com alto nível de empregabilidade serão recontratados com facilidade por outras empresas, garantindo a sobrevivência em outro emprego; eles podem preferir liquidar a empresa para receber os créditos, valendo-se da maior prioridade que terão em caso de falência. Se a empregabilidade é baixa, o credor tende a votar a favor da recuperação para manter os empregos por mais tempo.

A doutrina e a jurisprudência limitam a cessão de direitos trabalhistas. A cessão não tem sido reconhecida pela Justiça do Trabalho sob o argumento de se tratar de negócio jurídico com terceiros que não participam da relação laboral. A proibição desconsidera o fato de que a cessão somente pode se efetivar com a anuência do cessionário e que pode ser do interesse do trabalhador ceder os créditos a terceiros para receber algum valor mais rapidamente ${ }^{246}$.

\footnotetext{
${ }^{245}$ SZTAJN, Rachel. Notas sobre as assembléias de credores na lei de recuperação de empresas. Revista de Direito Mercantil, Industrial, Econômico e Financeiro, Ano XLIV, n. 138, abr./jun. 2005, p. 59.

246 "A Corregedoria Geral da Justiça do Trabalho pelo Provimento n.6, de 21.2.01, admite a cessão de crédito prevista no art. 286 do Código Civil de 2002, mas afirma não ser ela realizável na Justiça do Trabalho por ser negócio jurídico entre empregado e terceiro que não se coloca em quaisquer dos pólos da relação processual trabalhista. Divergimos desse entendimento, porque o art. 42 do CPC estatui que a alienação da coisa ou do direito litigioso, a título particular, por ato entre vivos, não altera a legitimidade das partes. $\mathrm{O}$ ingresso do cessionário no processo, como substituto processual do cedente, só se efetiva com a anuência da parte contrária. Em havendo oposição a essa pretensão do cessionário de direito, a lei (art. $42-2^{\circ}$ - CPC) autorizao a intervir no processo como assistente do cedente (ou reclamante no processo do trabalho)". (SAAD, E. G.; SAAD, J. E. D.; BRANCO, A. M. S. C. CLT Comentada. $38^{a}$ ed., São Paulo: LTR, 2005, p.767).
} 
Além disso, o art. 449 da CLT determina que os créditos salariais sejam privilegiados e os direitos trabalhistas subsistam em caso de falência. A LREF determina que o crédito cedido a terceiro converta-se em quirografário na falência (art. 83), mas nada dispõe em caso de recuperação judicial. Na falência, a lei limita a 150 salários mínimos o valor dos créditos trabalhistas (art. 83, I), mas não determina limite para os decorrentes de acidente de trabalho e os sujeitos a recuperação. Há, portanto, desalinhamento entre o tratamento dado ao crédito trabalhista na recuperação e na falência, podendo haver dúvidas sobre qual regra aplicar a cada caso.

A impossibilidade de realizar a cessão de créditos e a dificuldade em determinar o tratamento legal dado aos créditos trabalhistas na falência e na recuperação judicial podem afetar o interesse da classe de credores e a votação do plano de recuperação.

\section{III.3.3. Crise estrutural (empresa ineficiente).}

A crise estrutural é aquela na qual a empresa ineficiente apresenta crise irremediável que inviabiliza a sobrevivência no longo prazo.

As soluções mais prováveis e os principais erros de decisão para a crise são apresentados na figura abaixo. Os critérios para analisar as hipóteses descritas nessa seção são idênticos aos da seção anterior. 


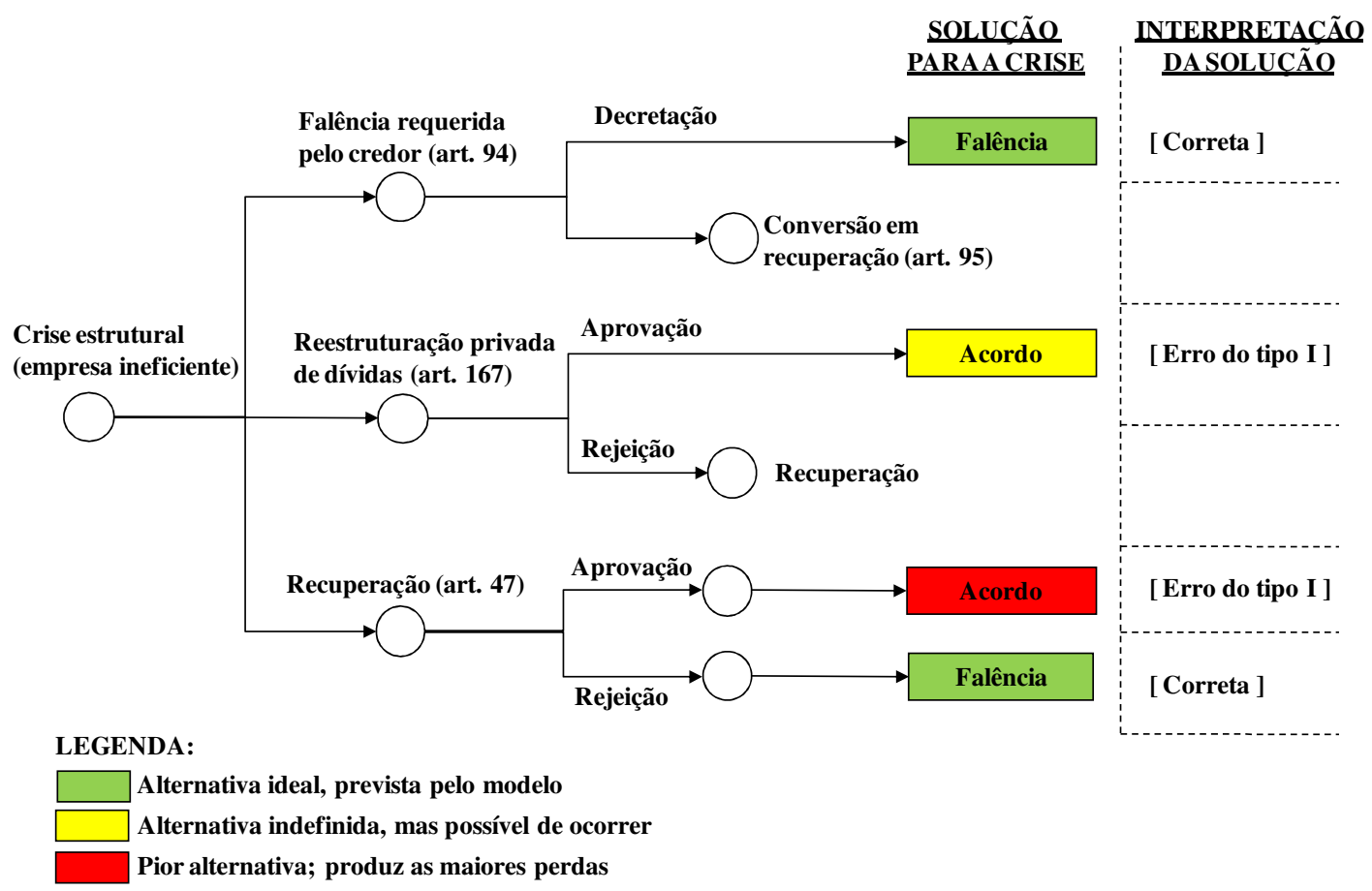

\section{a) Falência}

Do ponto de vista do interesse público, a solução ideal para a crise da empresa ineficiente é levá-la à falência, hipótese que não ocorre por iniciativa do devedor.

A LREF indica que a autofalência deve ser requerida pelo devedor que julgar não mais ter condições para honrar compromissos assumidos (art. 105) ${ }^{247}$. A lei estabelece um dever, mas não prevê punições para a inércia. Trata-se, na verdade, de faculdade atribuída ao devedor, que, ao tomar a decisão, não considera as reais condições de sobrevivência do negócio.

A autofalência é sempre a pior opção para o devedor, não importando se a empresa é ineficiente, pois ele só recebe algum valor depois de pagar todos os credores se houver ativos livres (art. 153) ${ }^{248}$. A escolha da autofalência é improvável, porque incoerente com o comportamento racional do devedor, exceto se ele for altruísta.

${ }^{247}$ LREF, Art. 105. "O devedor em crise econômico-financeira que julgue não atender aos requisitos para pleitear sua recuperação judicial deverá requerer ao juízo sua falência, expondo as razões da impossibilidade de prosseguimento da atividade empresarial (...)"

${ }^{248}$ LREF, “Art. 153. Pagos todos os credores, o saldo, se houver, será entregue ao falido”. 
O devedor pode não requerer a autofalência por iniciativa própria, mas não significa que permanecerá inerte. Ele usa os meios à disposição com o propósito de desviar ativos, preservando ganhos à custa de perdas para os credores ${ }^{249}$. A inércia refere-se tão somente a não tomar a iniciativa de requerer a autofalência. É apenas uma estratégia usada para adiá-la.

A autofalência depende de dois requisitos: a existência de crise e a impossibilidade de requerer a recuperação. $\mathrm{O}$ primeiro refere-se à inviabilidade do negócio, isto é, à condição de ineficiência da empresa. O segundo parece referir-se a quatro hipóteses: (i) proibição legal de requerer a recuperação judicial; (ii) devedor sabe que os credores rejeitarão o plano; (iii) devedor altruísta da empresa ineficiente, que opta pela falência, consciente de que o negócio é insustentável; (iv) desinteresse do devedor ou herdeiros em manter a empresa em operação, preferindo liquidá-la, mesmo que seja eficiente.

A primeira hipótese refere-se ao art. 48, que impede o devedor de requerer a recuperação se não cumprir os requisitos formais e prazos legais. A segunda sugere que o devedor sabe que os credores rejeitarão o plano, porque tal atitude foi sinalizada pelos credores antes ou durante a reestruturação privada de dívidas, efeito colateral de negociações mal sucedidas. A terceira supõe que o devedor opta pela falência porque a empresa é inviável, internalizando os prejuízos decorrentes da decisão, estratégia que não será escolhida pelo agente racional e auto-interessado, pois não lhe traz ganhos (art. 153). A quarta hipótese indica que o devedor ou os herdeiros, por razões outras, não demonstram interesse em continuar o negócio, decisão tomada com mais freqüência pelos herdeiros.

A falência também pode não ser do interesse dos credores com baixa prioridade na ordem de pagamento dos créditos, porque eles nada receberão. Por isso preferem a recuperação, pois terão condições de impor custos e transferir riscos ao devedor e aos

\footnotetext{
${ }^{249}$ Ver, a esse respeito: BAROSSI FILHO, Milton. As assembléias de credores e plano de recuperação de empresas: uma visão da teoria dos jogos. Revista de Direito Mercantil, Industrial, Econômico e Financeiro, Ano XLIV, n. 137, jan./mar. 2005, pp. 236-237; ROE, Mark J. Corporate reorganization and bankruptcy legal and financial materials. University Casebook Series, New York: Foundation Press, 2000, pp. 235-307; 535-576.
} 
demais credores.

Quando a falência é requerida pelo credor, a LREF permite que, no prazo da contestação, o devedor a evite, pleiteando a recuperação judicial (art. 95). No caso da empresa ineficiente, a permissão legal possibilita a recuperação (erro do tipo I), gerando prejuízos para a coletividade. A hipótese do art. 95 deveria ser permitida apenas para a empresa eficiente.

O devedor também pode não tomar nenhuma atitude a respeito da crise e deixar a decisão para os credores, o que dificilmente ocorre, porque ele nada ganha com tal atitude. Para a empresa ineficiente, a inércia do devedor pode implicar em pedido de falência requerido pelos credores, o que seria uma decisão correta.

No modelo proposto, a decisão de inércia tem os mesmos efeitos da autofalência, pois o devedor não obtém ganhos durante o procedimento concursal. A diferença, entretanto, reside no fato de que, ao permanecer inerte, o devedor pode manter-se por mais tempo à frente dos negócios, o que não ocorreria se optasse pela autofalência, quando é promovido seu afastamento (art. $75^{250}$ ). Para o devedor, a inércia é solução melhor do que requerer a autofalência.

O credor individual também pode permanecer inerte e deixar a decisão de requerer a falência para os demais credores. Ele provisiona as perdas e não investe recursos na negociação. É decisão aplicável ao credor que possui créditos de valor inferior aos custos incorridos com o procedimento concursal, ou créditos inferiores a quarenta salários mínimos e não consegue unir-se em litisconsórcio com outros credores para requerer a falência do devedor (art. 94, $§ 1^{\text {2 251 }}$ ).

Ao permanecer inerte, o credor evita incorrer em custos e a perda máxima equivale ao valor dos créditos devidos, razão pela qual, se preenche os requisitos legais e os custos são inferiores ao valor que espera receber, não tem incentivos para adiar o

\footnotetext{
${ }^{250}$ Art. 75. A falência, ao promover o afastamento do devedor de suas atividades, visa a preservar e otimizar a utilização produtiva dos bens, ativos e recursos produtivos, inclusive os intangíveis, da empresa.

${ }^{251}$ LREF, Art. 94, $\$ 1^{\circ}$. "Credores podem reunir-se em litisconsórcio a fim de perfazer o limite mínimo para o pedido de falência com base no inciso I do caput deste artigo".
} 
pedido de falência do devedor. Para o credor individual, a inércia é sempre a pior alternativa, exceto se os custos para agir forem proibitivos.

No caso da empresa ineficiente, as hipóteses de decisão nas quais não há erro são: (i) quando o juiz decreta a falência do devedor; (ii) ou quando o juiz confirma a decisão dos credores que rejeitam o plano de recuperação ${ }^{252}$.

\section{b) $\underline{\text { Reestruturacão privada de dívidas }}$}

A empresa pode preferir a negociação direta se obtiver maiores ganhos do que com a recuperação, isto é, se optar por pagar pequena parcela do valor devido aos credores. O problema é que a negociação não torna a empresa eficiente, apenas prolonga a crise. A solução ideal seria rejeitar a oferta e levar a empresa à falência, que pode não ocorrer se os credores preferirem receber parte do valor dos créditos mais depressa, deixando o problema da crise futura para outros credores. Nesse caso, ocorre o erro do tipo I, o reerguimento da empresa ineficiente.

À primeira vista, parece improvável que o devedor prefira a negociação direta à recuperação judicial, mas, como ele conhece a ineficiência da empresa, sabe que, no futuro, enfrentará o problema outra vez. Se requerer a recuperação, terá que respeitar as condições legais e aguardar o prazo de cinco anos previsto pelo art. 48 para pleitear o benefício uma vez mais ${ }^{253}$. Se o prazo for insuficiente para manter a empresa em operação, pode preferir negociar as dívidas de curto prazo e deixar para usar a alternativa de recuperação em momento posterior. Nesse caso, a reestruturação é maneira de "ganhar tempo", porque a recuperação judicial se torna jogo de interação

\footnotetext{
${ }^{252}$ Ver discussão a respeito da decisão assemblear (capítulo IV).

${ }^{253}$ LREF, Art. 48. "Poderá requerer recuperação judicial o devedor que, no momento do pedido, exerça regularmente suas atividades há mais de 2 (dois) anos e que atenda aos seguintes requisitos, cumulativamente: I - não ser falido e, se o foi, estejam declaradas extintas, por sentença transitada em julgado, as responsabilidades daí decorrentes; II - não ter, há menos de 5 (cinco) anos, obtido concessão de recuperação judicial; III - não ter, há menos de 8 (oito) anos, obtido concessão de recuperação judicial com base no plano especial de que trata a seção V deste capítulo; IV - não ter sido condenado ou não ter, como administrador ou sócio controlador, pessoa condenada por qualquer dos crimes previstos nesta Lei. Parágrafo único. A recuperação judicial também poderá ser requerida pelo cônjuge sobrevivente, herdeiros do devedor, inventariante ou sócio remanescente".
} 
única $^{254}$ para a empresa. Se a negociação fracassar, a empresa ineficiente optará pela recuperação para tentar evitar a falência.

Em caso de fracasso das negociações, os credores podem chegar às mesmas conclusões e optar por requerer a falência do devedor. A solução, entretanto, é inócua, porque o devedor pode requerer a conversão em recuperação judicial no prazo da contestação (art. 95).

\section{c) $\underline{\text { Recuperacão }}$}

A recuperação é mais atrativa para o devedor quanto maior a incerteza a respeito do futuro da empresa e a quantidade de dívidas vencendo no longo prazo, uma vez que a necessidade de tomar empréstimos para cobrir o déficit imediato será menor. Em caso de "bom resultado", isto é, existência de saldo após o pagamento das dívidas negociadas, o devedor recebe o valor excedente. Em caso de "mau resultado", o devedor perde apenas o valor emprestado, e os credores perdem o restante.

O devedor tem maior propensão para riscos que os credores. Quando os ganhos são incertos, a recuperação é investimento de risco, mas o devedor a prefere mesmo quando a liquidação é mais eficiente, uma vez que permite extrair renda dos credores, transferindo-lhes parte da incerteza sobre a continuidade dos negócios ${ }^{255}$. Por isso, Lorenzo Stanghellini sustenta, com razão, que o devedor tem incentivos para assumir novos riscos se o capital de risco foi perdido, e não tem interesse em realizar novos investimentos se o valor dos débitos for muito grande ${ }^{256}$.

O devedor tende a escolher a alternativa que maximiza o ganho individual, não

\footnotetext{
${ }^{254}$ Neste tipo de jogo o agente tem uma única possibilidade de escolher a estratégia correta, não havendo maneiras de corrigi-la. Se não puder observar o comportamento do líder, jogador bem informado, a decisão pode se tornar arriscada. (CAMERER, Colin F. Camerer; HO, Teck-Hua; CHONG, Juin-Kuan. A cognitive hierarchy theory of one-shot games and experimental analysis. September 8, 2003. Disponível em $<$ http://www.ssrn.com>. Acesso em: 03.dez.2006)

${ }^{255}$ No mesmo sentido: SZTAJN, Rachel. Notas sobre as assembléias de credores na lei de recuperação de empresas. Revista de Direito Mercantil, Industrial, Econômico e Financeiro, Ano XLIV, n. 138, abr./jun. 2005, p. 67.

${ }^{256}$ STANGHELLINI, Lorenzo. Proprietà i controllo dell'impresa in crisi. Rivista delle Società, Ano $49^{\circ} /$ 2004, Set./Out. 2004, fascículo 5º, pp. 1078-1080.
} 
importando se há perdas para os credores. A incerteza favorece a opção pela recuperação porque, nesse caso, os credores são mais onerados pelos riscos adicionais com a continuação do negócio. A opção pela recuperação é decisão exclusiva do devedor (art. 48) e a liquidação lhe é sempre prejudicial (art. 153). O devedor prefere a recuperação, já que o ganho obtido com o desconto das dívidas é maior do que o valor que receberia em caso de liquidação. Ele ignora os prejuízos para os credores quando toma a decisão.

Os credores menos privilegiados pouco ou nada receberão, havendo redistribuição de benefícios para o devedor. Este, ao requerer a recuperação, desconsidera as perdas dos credores ${ }^{257}$. Para continuar em funcionamento e cobrir despesas de operação, a empresa precisa obter financiamento na forma de perdão de dívidas ou mediante novos empréstimos. A recuperação é atrativa se os ganhos com a continuação, descontados os custos, são maiores que o valor financiado. Para o devedor, a atratividade aumenta quanto maior a incerteza a respeito do futuro da empresa. Se os ganhos forem imprevisíveis ou desconhecidos, a decisão depende da probabilidade de sucesso da continuação dos negócios. Ela é ainda mais atrativa para o devedor se a empresa tiver grande quantidade de dívidas vencendo no longo prazo, pois há maior possibilidade de compartilhamento de perdas futuras com os credores.

Os administradores das empresas ineficientes sempre têm incentivos para requerer a recuperação para serem mantidos na condução dos negócios durante a crise. Eles tentarão usar os ativos para pagar dívidas correntes e permanecer o maior tempo possível afastados da falência, dilapidando ativos e reduzindo a possibilidade de pagamento de parcela maior das dívidas. Os indícios mais evidentes de tal comportamento são: (i) realocação de riscos antes da institucionalização da crise, por meio de reavaliações contábeis de ativos, fusões, incorporações, redistribuição de ativos entre a sociedade controladora, controladas e $\operatorname{coligadas}^{258}$; (ii) gastos excessivos

\footnotetext{
${ }^{257}$ Michelle White alcança conclusões opostas às nossas para as empresas norte-americanas, pois, naquele país, há maior probabilidade de o devedor em crise requerer a autofalência. (WHITE, Michelle J. The corporate bankruptcy decision. In: POSNER, Richard; PARISI, Francesco, Law and Economics. Cheltenham, UK: Lyme, US: Edward Elgar Publishing, Volume III, p. 349).

${ }^{258}$ BAROSSI FILHO, Milton. As assembléias de credores e plano de recuperação de empresas: uma visão da teoria dos jogos. Revista de Direito Mercantil, Industrial, Econômico e Financeiro, Ano XLIV, n. 137,
} 
por parte dos administradores; (iii) desinvestimentos e cancelamento de projetos. Algumas dessas condições são previstas pelo art. 64 da lei, e autorizam o afastamento do devedor ${ }^{259}$.

Alguns desses comportamentos podem ser interpretados como fraude. Edward Altman entende que existem dois tipos de fraude, a intencional e a construtiva. A intencional verifica-se com a transferência de ativos antes da decretação da falência ou recuperação, com o objetivo de fraudar credores. A fraude construtiva ocorre quando há transferência irregular, sem haver intenção ilícita. Ocorre a fraude quando não há contrapartida em valor equivalente, recebido pela sociedade que cedeu os ativos, ou quando resulta em insolvência ou subcapitalização $0^{260}$. O problema é que a identificação da fraude requer a avaliação dos ativos e passivos no momento em que a operação é realizada, tarefa que pode ser complexa e demorada.

Segundo Robert Clark, a lei pode rever ou impedir as transferências de ativos realizadas pelo devedor, incluindo atos fraudulentos e também os realizados sem a intenção de prejudicar credores ${ }^{261}$. A fraude pode tomar a forma de "compra alavancada", operação na qual se transfere o negócio para terceiros usando os créditos pendentes como forma de pagamento. Quando bem sucedida, a compra pode evitar a falência, mas a um custo social alto. Tal operação pode ser realizada pelos administradores e toma a forma de "compra alavancada" quando parte dos fundos usados para aquisição são obtidos com investidores que serão pagos com os resultados futuros gerados pela empresa. Clark indica que a doutrina do controle de fraude vem sendo superada pela noção de subordinação equitativa, que permite transferir créditos em condições de justiça e eqüidade, se a sociedade devedora for controlada por

jan./mar. 2005, pp. 236-237; ROE, Mark J. Corporate reorganization and bankruptcy - legal and financial materials. University Casebook Series, New York: Foundation Press, 2000, pp. 235-307; 535-576.

${ }^{259}$ LREF, art. 64: "Durante o procedimento de recuperação judicial, o devedor ou seus administradores serão mantidos na condução da atividade empresarial, sob fiscalização do Comitê, se houver, e do administrador judicial, salvo se qualquer deles: (...) IV - houver praticado qualquer das seguintes condutas: a) efetuar gastos pessoais manifestamente excessivos em relação a sua situação patrimonial; b) efetuar despesas injustificáveis por sua natureza ou vulto, em relação ao capital ou gênero do negócio, ao movimento das operações e a outras circunstâncias análogas; c) descapitalizar injustificadamente a empresa ou realizar operações prejudiciais ao seu funcionamento regular;"

${ }^{260}$ ALTMAN, Edward I. Corporate financial distress and bankruptcy: a complete guide to predicting and avoiding distress and profiting from bankruptcy. $2^{\text {nd }}$ ed., New York: John Wiley, 1993, pp. 92-97; 140.

${ }^{261}$ Há regras na LSA para tentar coibir tais comportamentos (arts. $8^{\circ}, 243,245,247,248,252$ ). 
credores $^{262}$.

Outra sinalização possível de ineficiência da empresa é a quantidade de esforço despendido pelos administradores na gestão da crise, situação difícil de ser observada pelos credores. Os administradores de empresas eficientes tendem a trabalhar mais, visto que há reais expectativas de recuperação, embora nem todo o esforço adicional reverta em seu benefício, uma vez que os credores e acionistas capturam parte do retorno. Os administradores de empresas ineficientes tendem a trabalhar menos porque a declaração de falência é inevitável e eles terão pouco retorno pelo esforço de gestão. O esforço dos administradores na gestão pode ser indicação de eficiência da empresa, mas o contrário não é verdadeiro; se não se esforçam, a empresa pode ser ineficiente ou eficiente ${ }^{263}$.

A empresa ineficiente tende a preparar plano que preveja pagamento insuficiente do valor dos créditos, visto que é incapaz de realizar pagamento significativo. Ela se vale da atitude de barganhar e tenta extrair renda dos credores, redistribuindo riscos.

O erro em recuperar a empresa ineficiente (erro do tipo I) decorre dos problemas de assimetria informacional. Com exceção do devedor, é difícil para qualquer outro agente fazer a distinção entre a empresa eficiente e a ineficiente. Isso permite ao devedor induzir os credores a erro por meio de sinalizações incorretas.

Para os credores, é imprescindível conhecer o mais cedo possível a espécie de empresa (eficiente ou ineficiente) com a qual estão lidando. Se o credor negocia habitualmente com o devedor, tende a perceber a crise mais depressa.

Os credores podem tentar reduzir a assimetria avaliando a oferta de pagamento feita pelo devedor no plano e estimando a probabilidade da empresa ser eficiente,

${ }^{262}$ CLARK, Robert C. Corporate law. New York: Aspen Law and Business, 1986, pp. 40-44; 52-53; 500; 511.

${ }^{263}$ WHITE, Michelle J. Corporate bankruptcy. Disponível em: <http://www.ssrn.com>. Acesso em: 16.abr.2006, pp. 16-17. 
condicionada à probabilidade de oferta de pagamento significativo ${ }^{264}$. Explicado de outra maneira, se o credor supõe que a empresa é eficiente e recebe oferta de pagamento significativo, pode imaginar que avaliou corretamente a situação. Se, entretanto, recebe oferta insuficiente, pode supor que a empresa é ineficiente.

Além disso, há duas estratégias dominantes ${ }^{265}$ para o credor, não importando se a empresa é eficiente: (i) negociar com o devedor, tentando obter o maior ganho possível para receber parte do valor dos créditos em prazo mais curto; (ii) rejeitar plano de recuperação que ofereça pagamento insuficiente. Entretanto, essas estratégias nem sempre são adotadas devido aos erros causados pela existência de informação assimétrica.

Como os administradores têm incentivos para mentir sobre a real situação da empresa, os credores devem sempre rejeitar a oferta de pagamento insuficiente, verificando se há contra-oferta do devedor. Se houver, pode ser sinalização de que a empresa é eficiente. O problema é que as regras previstas na LREF não permitem a renegociação da oferta nem a apresentação de plano alternativo pelos credores. A proposta inicial feita pelo devedor é definitiva e, se os credores rejeitam o plano, o juiz deve decretar a falência da empresa (art. $56, \$ 4^{\circ}$ c/c art. 73, III $^{266}$ ). Entretanto, o juiz pode aprovar plano rejeitado por meio da decretação do cramdown, ou da atribuição de valor positivo (aprovação do plano) ao voto dos ausentes ${ }^{267}$. Nestes casos, há erro de avaliação (erro do tipo I) porque a empresa ineficiente não deve ser recuperada.

A demora no encerramento do procedimento afeta a decisão dos credores, que

\footnotetext{
${ }^{264}$ Os credores podem estimar se o pagamento é suficiente usando o Teorema de Bayes, no qual conhecem a probabilidade incondicional da empresa ser eficiente e estimam a probabilidade de pagamento. (WHITE, Michelle J. Corporate bankruptcy as a filtering device: Chapter 11 reorganizations and out-of-court debt restructurings. Journal of Law, Economics and Organization, n. 10, pp. 268-295, 1984). O Teorema de Bayes é usado para calcular a probabilidade de um evento condicionada à ocorrência de outro. (HOEL, Paul G. Estatística elementar. São Paulo: Atlas, 1977, pp. 72-76).

${ }^{265}$ Estratégia dominante é aquela que deve sempre ser escolhida pelo jogador racional, ou seja, é sempre melhor do que as demais alternativas.

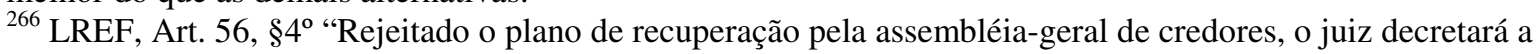
falência do devedor".

"Art. 73. O juiz decretará a falência durante o processo de recuperação judicial: (...) III - quando houver sido rejeitado o plano de recuperação, nos termos do $\S 4^{\circ}$ do art. 56 desta Lei"; (...)

${ }^{267}$ Ver seção IV.3.
} 
podem preferir evitar a deterioração dos ativos do devedor e requerer a falência ${ }^{268}$. Tal opção contrasta com as regras legais, que parecem tender para a aprovação do plano, afetando os descontos aplicados sobre os créditos de cada classe.

O devedor encontrará dificuldades para obter empréstimos e resolver a crise. A LREF não traz incentivos para os credores financiarem a empresa e não há mercado secundário de créditos $^{269}$. Além disso, calcular o valor da empresa é tarefa complexa que, se mal realizada, beneficia o devedor. Isso porque ele perde menos quando os ganhos são incertos, mas os credores sempre perdem se a recuperação não é bem sucedida.

Há diversos incentivos previstos na LREF que beneficiam o devedor e permitem reforçar os argumentos apresentados: (i) a permanência do devedor à frente dos negócios (art. 64); (ii) o prazo de suspensão das ações e execuções por cento e oitenta dias (art. $6^{\circ}, \S 4^{\circ}$ ); (iii) o prazo de sessenta dias para elaboração do plano de recuperação judicial (art. 53); (iv) o vencimento antecipado de dívidas na falência (art.

\footnotetext{
${ }^{268}$ Amos Tversky e Daniel Kahnemann demonstram que, entre uma escolha segura e outra arriscada, as pessoas preferem a opção de menor risco quando é enquadrada como ganho, e a opção arriscada quando é enquadrada como perda. Isso significa que as pessoas geralmente avaliam escolhas a partir de um ponto de referência e tendem a assumir riscos maiores quando todas as opções são arriscadas. (TVERSKY, Amos; KAHNEMANN, Daniel. Prospect Theory: An Analysis of Decision Under Risk. Econometrica, Vol. 47, n. 2, pp. 263-292, Mar. 1979; TVERSKY, Amos; KAHNEMANN, Daniel. Rational Choice and the Framing of Decisions. Journal of Business, Vol. 59, n. 4, Part. 2: The Behavioral Foundations of Economic Theory, pp. S251-278, Oct. 1982; ROE, Mark J. Corporate reorganization and bankruptcy - legal and financial materials. University Casebook Series, New York: Foundation Press, 2000, pp. 129-131)

${ }^{269}$ Adriana Gardino parece sugerir uma explicação para a não formação do mercado secundário no Brasil, ao descrever o problema da concordata branca no Decreto-Lei n. 7.661/45: "O princípio da par condicio creditorum - igualdade entre os credores - exige que todos sejam pagos no mesmo momento e em igualdade de condições. Mas a questão é que a concordata atingia apenas os credores quirografários, limitando as chances de recomposição do passivo do devedor. De qualquer modo, o devedor estava impedido de negociar diretamente com o credor - sob pena de caracterização dos atos de falência e risco de quebra -, de modo que se tornavam extremamente restritas as oportunidades negociais do devedor, sujeitando-o a perder vantagens que poderiam até mesmo facilitar o cumprimento da concordata. Na prática, o que acabava ocorrendo era que o devedor valia-se do instrumento da cessão de crédito e 'adquiria', por intermédio de terceiro, alguns ou todos os créditos submetidos ao favor legal - circunstância esta que criava um mercado paralelo em torno do passivo sujeito ao favor legal, vulgarmente denominado 'concordata branca' - que eram negociados em condições diversas daquelas previstas em lei para o cumprimento do favor legal. Criavam-se, assim, às margens do processo e sem nenhum controle judicial, as verdadeiras condições da moratória do devedor. Havia, de um lado, um número de credores premidos pelo receio de jamais realizar o crédito sujeito à concordata, então designado 'moeda podre', ante a possibilidade da quebra; e, por outro lado, remanescia o devedor, que nem sempre tinha condições de promover uma repactuação dos créditos sujeitos à concordata pelo instrumento das cessões". (GARDINO, Adriana V. P. A evolução do tratamento jurídico da empresa em crise no direito brasileiro. Dissertação de Mestrado. São Paulo: Faculdade de Direito da Universidade de São Paulo, 2006, p. 50).
} 
77). Estes e outros incentivos, resumidos a seguir, explicam, em parte, porque o devedor tem vantagens na negociação com os credores.

A manutenção do devedor à frente dos negócios é a regra na LREF (art. 64). Se a crise for causada por má gestão do devedor, sua manutenção no comando da empresa pode agravar ainda mais a situação. Entretanto, o controlador e a administração atual conhecem mais a respeito do negócio do que terceiros designados para administrar a crise $^{270}$. A manutenção do devedor da empresa ineficiente à frente do negócio cria incentivos para a continuidade da má gestão, agravando a crise. Já a manutenção do devedor da empresa eficiente no comando pode ser benéfica para o sucesso da recuperação.

Calixto Salomão Filho procura resolver o problema, sugerindo a profissionalização da gestão e a efetiva supervisão judicial sobre os atos do devedor, administradores e controladores, configurando controle compartilhado entre estes, o administrador judicial e o comitê de credores. $\mathrm{O}$ autor entende que o instituto da golden share pode ser adaptado à recuperação judicial e o plano pode estabelecer formas de controle gerencial para evitar que decisões sejam tomadas pelo controlador, sem afastálo de sua participação societária ${ }^{271}$. O controle compartilhado pode auxiliar a reduzir os abusos causados pelo controlador, mas a profissionalização da gestão não é solução de fácil operacionalização. Além disso, quando a empresa apresenta patrimônio líquido negativo, o devedor não mais participa da composição do capital social e a empresa é, de fato, dos credores; não há propósito em haver compartilhamento de controle quando o devedor não mais participa dos riscos do empreendimento ${ }^{272}$.

O segundo incentivo, a suspensão de 180 dias (art. $6^{\circ}, \S^{\circ}$ ), permite ao devedor manter controle absoluto sobre o negócio e as informações disponibilizadas ao público,

\footnotetext{
${ }^{270}$ A LREF não conceitua adequadamente as figuras do devedor, controlador e administradores da empresa. Há desalinhamento com a legislação societária que regula as sociedades anônimas e as limitadas. A esse respeito ver: VERÇOSA, Haroldo M. D. O status jurídico do controlador e dos administradores na recuperação judicial. Revista de Direito Mercantil, Industrial, Econômico e Financeiro, n. 143, pp.21-38, Jul.-Set. 2006.

${ }^{271}$ SALOMÃO FILHO, Calixto. Recuperação de empresas e interesse social. In SOUZA JR, Francisco Satiro de; PITOMBO, Antonio Sérgio A de Moraes (coord.). Comentários à lei de recuperação de empresas e falência. São Paulo: Revista dos Tribunais, 2005, pp. 50-51.

${ }^{272}$ Ver seção II.1.
} 
aumentando o poder de negociação em face dos credores. A suspensão pode incentivar a prática de comportamentos não-cooperativos e permite elaborar estratégias oportunistas, valendo-se da informação assimétrica que não será revelada durante a vigência do benefício ${ }^{273}$. Eduardo Munhoz sustenta que a prorrogação do prazo é exceção, devendo ser limitada aos casos em que o prazo tenha expirado por motivos alheios à vontade do devedor, desde que haja efetiva possibilidade do plano de recuperação vir a ser aprovado ${ }^{274}$. A sugestão, entretanto, depende de se conhecer, com antecedência, a probabilidade de aprovação do plano, informação difícil de ser obtida no momento em que se outorga o prazo de suspensão.

A respeito do terceiro incentivo, o prazo de sessenta dias para elaboração do plano de recuperação judicial (art. 53), Rachel Sztajn preleciona que deveria ser apresentado esboço do plano de salvação da empresa junto com o pedido de recuperação, uma vez que a crise é preexistente ao pedido, permitindo supor que o devedor já deveria ter elaborado estratégias para corrigir o problema. A autora afirma que o prazo de sessenta dias parece ser um "período de graça” outorgado à empresa; sugere alteração no referido artigo a fim de permitir que o esboço de plano seja entregue junto com o pedido de recuperação, outorgando-se prazo adicional de trinta dias para o devedor apresentar detalhamento ${ }^{275}$. Eduardo Munhoz afirma que o prazo legal de sessenta dias parece se referir à possibilidade que a lei dá às partes de negociar o plano antes do devedor apresentá-lo ao juiz, podendo gerar incentivos negativos ao devedor e às classes de credores com maior poder de barganha, na medida em que permite configurar plano que atenda mais aos seus interesses do que ao interesse coletivo $^{276}$. Os argumentos sugerem que a concessão de prazo ao devedor, sem a contrapartida em revelação de informações, pode ser vantajosa para o devedor

\footnotetext{
${ }^{273}$ Edward Altman entende que a prorrogação do prazo nos Estados Unidos é prática comum, mas acredita que não deva ser permitida. (ALTMAN, Edward I. Corporate financial distress and bankruptcy: a complete guide to predicting and avoiding distress and profiting from bankruptcy. $2^{\text {nd }}$ ed., New York: John Wiley, 1993, pp. 85-87)

${ }^{274}$ MUNHOZ, Eduardo S. Comentários. In SOUZA JR, Francisco Satiro de; PITOMBO, Antonio Sérgio A de Moraes (coord.). Comentários à lei de recuperação de empresas e falência. São Paulo: Revista dos Tribunais, 2005, pp. 272-274.

${ }^{275}$ SZTAJN, Rachel. Comentários. In SOUZA JR, Francisco Satiro de; PITOMBO, Antonio Sérgio A de Moraes (coord.). Comentários à lei de recuperação de empresas e falência. São Paulo: Revista dos Tribunais, 2005, p. 265.

${ }^{276}$ MUNHOZ, Eduardo S. Comentários. In SOUZA JR, Francisco Satiro de; PITOMBO, Antonio Sérgio A de Moraes (coord.). Comentários à lei de recuperação de empresas e falência. São Paulo: Revista dos Tribunais, 2005, p. 272.
} 
oportunista.

Por fim, o vencimento antecipado de dívidas pode ser vantajoso para o credor em caso de falência, se esta for mais célere do que a recuperação judicial, pois permite recuperar parte do valor devido em menor tempo. Entretanto, pode se tornar incentivo para o devedor optar pela recuperação, para negociar redução maior no valor das dívidas previstas no plano, uma vez que pode acrescentar uma taxa de desconto ${ }^{277}$ sobre as dívidas, justificada pela antecipação do pagamento.

${ }^{277}$ A taxa de desconto é usada para trazer a valor presente um determinado valor futuro. 


\section{Efeitos.}

O capítulo III demonstra haver desalinhamento entre as soluções previstas na lei e as obtidas a partir do modelo proposto, indicando que os incentivos legais são insuficientes para evitar a ocorrência de erros de avaliação.

Os principais efeitos decorrentes do desalinhamento são: (i) erros no mecanismo de seleção de empresas submetidas a concurso; (ii) existência de incentivos à produção de informações assimétricas; (iii) instabilidade da atividade de votação em assembléia de credores; (iv) efeitos de segunda ordem.

Neste capítulo, discutimos os efeitos e propomos soluções para compatibilizar os incentivos legais com as previsões do modelo teórico. Pretendemos indicar apenas os principais problemas, sem solucioná-los todos. Desconsideramos também outras correções de menor complexidade, necessárias para ajustar a LREF ao modelo.

\section{IV.1. Espécie de empresa submetida a concurso de credores.}

A LREF não é mecanismo compatível em termos de incentivos porque não induz a revelação de informação privada e não impede a ocorrência de erros de avaliação da empresa submetida a concurso.

As soluções previstas pelo modelo são a decretação da falência da empresa ineficiente e a recuperação da eficiente. Elas nem sempre são obtidas com a aplicação das regras previstas na LREF, podendo ocorrer os dois tipos de erros descritos.

A empresa eficiente tentará não ser submetida a concurso, evitando resolver o problema pela via judicial. Por isso, em boa parte dos casos, a lei pode acabar submetendo a concurso somente as empresas ineficientes. O problema é que a lei e a jurisprudência parecem ter maior predisposição à recuperação do que à falência ${ }^{278}$. Como tal tendência independe de se saber se a empresa é eficiente, a lei pode funcionar

\footnotetext{
${ }^{278}$ Essa propensão é indicada pelo evento da natureza previsto no modelo, que necessita de confirmação por análises estatísticas (ver capítulo V).
} 
como incentivo negativo para a empresa ineficiente tentar barganhar com os credores, impondo-lhes perdas ainda maiores. Nesse caso, por causa dos erros de avaliação, amplia-se o problema de seleção adversa ${ }^{279}$ de empresas submetidas a concurso e induzse o aparecimento de maior quantidade de erro do tipo I (recuperação da empresa ineficiente).

É possível que a lei venha a recuperar maior quantidade de empresas ineficientes, mas também poderão existir empresas eficientes submetidas a concurso. A segunda hipótese pode acontecer em três situações: (i) ocorrência de erro do tipo II, causado por qualquer fator que afete o diagnóstico da crise; (ii) evento externo inevitável ou imprevisível, como por exemplo, mudanças no mercado e nas preferências dos consumidores, difíceis de serem previstas ou mitigadas pelo devedor; (iii) o "efeito da passagem do tempo".

As duas primeiras já foram tratadas. O erro do tipo II é situação na qual se supõe que a empresa é ineficiente, levando à decisão de liquidação de negócio próspero $^{280}$. O evento externo inevitável e imprevisível é uma das possíveis causas de aparecimento da crise ${ }^{281}$.

A terceira situação é o "efeito da passagem do tempo", demora que causa degradação das condições da empresa. Neste caso, os prejuízos impostos pelo procedimento concursal oneram a empresa, tornando-a ineficiente. Se o procedimento de recuperação judicial for mais demorado que o de falência ${ }^{282}{ }^{283}$, o credor pode

\footnotetext{
${ }^{279}$ Ver seção III.2.

${ }^{280}$ Seção II.3.

${ }^{281}$ Seção II.2.

${ }^{282}$ Michelle White calcula que o prazo médio da liquidação (14 meses) é menor que o da recuperação judicial (17 meses), sugerindo que esta carece de celeridade. (WHITE, Michelle J. The corporate bankruptcy decision. In: POSNER, Richard; PARISI, Francesco, Law and Economics. Cheltenham, UK: Lyme, US: Edward Elgar Publishing, Volume III, pp. 350-351; 360-361). Mark Roe indica que a recuperação dura, em média, dois a três anos. (ROE, Mark J. Corporate reorganization and bankruptcy - legal and financial materials. University Casebook Series, New York: Foundation Press, 2000, p. 12)

${ }^{283}$ A LREF adota o princípio da celeridade processual apenas para a hipótese de falência (art. 75, parágrafo único). A celeridade é princípio que rege a lei concursal brasileira também para a recuperação judicial, mas não há menção à recuperação extrajudicial ou ao plano especial para micro e pequenas empresas. Ver princípio 7 do PLC n. 71/03: "7 - Celeridade e eficiência dos processos judiciais: é preciso que as normas procedimentais na falência e na recuperação judicial sejam, na medida do possível, simples, conferindo-se celeridade e eficiência ao processo e reduzindo-se a burocracia que atravanca seu curso." (Íntegra da publicação da LREF, in <http://www.senado.gov.br>. Acesso em: 17.05.2006).
} 
preferir a quebra porque terá maior certeza a respeito da ordem de pagamento, ao passo que na recuperação dependerá de plano que lhe seja benéfico e votação favorável nas assembléias de credores $^{284}$. Como o procedimento previsto na lei tende a ser demorado e dispendioso, o risco pode ser substancial e deve ser considerado.

\section{IV.2. Revelação de informações.}

\section{IV.2.1. Incentivos para sonegação de informação.}

A assimetria de informações indica que o devedor sabe mais a respeito da real situação dos negócios do que os credores e o juiz. Como não há sanção prevista na LREF para o devedor que sonega informação ou produz plano de recuperação que sabe será mal sucedido, há incentivos para induzir os credores e o juiz em erro.

A assimetria parece ser sempre vantajosa para o devedor, mas pode ser-lhe prejudicial se houver alto grau de incerteza. Nesse caso, os credores podem preferir evitar perdas, requerendo a falência. A atitude depende da avaliação da empresa (valor do negócio) e das condições de pagamento previstas no plano de recuperação.

A ordem de pagamento de créditos funciona como incentivo para produção de informações assimétricas porque a falência, em princípio, abrange todos os créditos e há ordem predeterminada para pagamento, mas, na recuperação, o devedor pode escolher quais credores pagar. Há, portanto, incentivos para que os credores avaliem sua posição relativa na ordem de pagamento e escolham a solução que melhor atenda aos interesses individuais, considerando os prazos e os valores estimados para pagamento $^{285}$.

A LREF nem sempre facilita a revelação de informações. A lei parece ser severa na definição das classes de credores, prazos de suspensão das ações e execuções, momento para apresentação do plano de recuperação e termo legal da falência, não

\footnotetext{
${ }^{284}$ Rachel Sztajn entende que a passagem do tempo sempre prejudica a coletividade de credores. (SZTAJN, Rachel. Notas sobre as assembléias de credores na lei de recuperação de empresas. Revista de Direito Mercantil, Industrial, Econômico e Financeiro, Ano XLIV, n. 138, abr./jun. 2005, pp. 61-62)

${ }^{285}$ Seção III.2.
} 
havendo discricionariedade para o juiz ajustar os prazos e condições ao caso concreto e evitar a prática de comportamentos oportunistas.

A lei também não estabelece critérios específicos para a atuação do juiz, que poderá resultar em falta ou excesso de intervenção. Se a lei, a partir de parâmetros préestabelecidos, permitisse ao juiz usar de algum grau de discricionariedade para definir a melhor alocação de credores em cada classe, poderia reduzir o problema da heterogeneidade de classes. Da mesma forma, para coibir comportamentos oportunistas, a adequação do prazo de suspensão das ações e execuções contra o devedor e do termo legal da falência ao caso concreto. Não tratamos esses e outros temas em detalhes neste trabalho; sugerimos, entretanto, que a lei deveria ter estabelecido parâmetros mais flexíveis para balizar a atuação do juiz às condições da crise e do mercado.

A proposta de pagamento permite revelar informação relevante, devendo envolver três conceitos aplicáveis às regras de aprovação do plano e também ao problema da decretação do cramdown $^{286}$ : (i) uniformização de pagamento intra-classe; (ii) uniformização de pagamento inter-classes; (iii) o "teste do melhor interesse dos credores" ${ }^{287}$. O primeiro critério corresponde ao pagamento equitativo e pro rata aos credores de mesma classe que detêm créditos de idêntica natureza. $\mathrm{O}$ segundo refere-se à ordem de prioridade entre as diversas classes, isto é, determina que as classes mais privilegiadas devam ser pagas antes das menos prioritárias. Por fim, o "teste do melhor interesse dos credores" indica que o juiz deve confirmar plano aprovado pela maioria dos credores somente se credor dissidente receber ao menos o valor que receberia em caso de falência. O "teste" protege o credor individual que não aprova o plano, enquanto os outros dois critérios visam a proteger classes de credores prejudicadas, não o credor individual.

A lei de falências norte-americana utiliza conceitos similares. Para não haver tratamento diferenciado, o plano de recuperação previsto no Bankruptcy Code deve satisfazer dois requisitos: (i) não ocorrer discriminação injusta; (ii) ser plano justo e

\footnotetext{
${ }^{286}$ O cramdown é tratado na seção IV.3.

${ }^{287} \mathrm{O}$ termo originalmente usado pela doutrina norte-americana é "best-interest-of-creditors test". Em nosso trabalho, os conceitos foram adaptados à realidade brasileira.
} 
equitativo $^{288}$. O primeiro determina que os credores de mesma classe sejam tratados da mesma maneira, recebendo pagamento proporcional aos créditos de natureza similar. $\mathrm{O}$ segundo indica que a ordem de prioridade de pagamento deve ser respeitada, afetando credores de classes distintas e evitando que classes com prioridade inferior sejam pagas antes das classes de maior prioridade.

Segundo Mark Roe, o conceito de plano justo e equitativo requer que seja realizada a avaliação da empresa, pois a justiça refere-se à distribuição dos valores e, por isso, depende do valor dos créditos que serão objeto de negociação ${ }^{289}$. A noção de discriminação injusta indica que deve haver tratamento igualitário e pro rata dos créditos de mesma natureza pertencentes a uma classe. $\mathrm{O}$ "teste do melhor interesse dos credores" estabelece que, para ser confirmado pelo juiz, o plano aprovado deve prever que o credor individual dissidente receba ao menos o valor que receberia em caso de liquidação, exceto se ele desistir da vantagem.

Mark Roe entende, com razão, que nenhuma regra de discriminação é mais justa do que outra. Ele associa a noção de justiça com a possibilidade de saber se a regra é clara e conhecida por todos antes do concurso, porque o contrato celebrado teria o condão de alocar os riscos entre as partes. Se a norma jurídica cria o risco de o credor não ser pago, então ele aumentará as taxas de juros para compensar o risco adicional de conceder o empréstimo ou não emprestará dinheiro para empresas com baixa probabilidade de pagar as dívidas. Se a regra de discriminação for clara e predefinida, os credores não serão surpreendidos. O resultado pode ser até diferente do esperado, porque não se podem prever todas as contingências, mas não será "injusto".

Explicado de outra forma, a lei não deve apenas proteger as expectativas dos credores, mas deve defini-las para que os "sócios sem direitos" não sejam surpreendidos por mudanças durante o procedimento concursal. Justiça, nesse sentido, significa examinar se determinado conjunto de regras legais, previamente definido, é

\footnotetext{
${ }^{288}$ Respectivamente, unfair discrimination e fair and equitable plan.

${ }^{289}$ Seção III.2.
} 
mais claro e fácil de entender do que outro ${ }^{290}$.

Segundo a LREF, não há obrigatoriedade de tratamento igualitário dos credores no plano de recuperação ${ }^{291}$ e há dúvidas a respeito da rigidez das regras que estabelecem a ordem de pagamento em caso de falência (arts. 83; 84; 149). O princípio de pagar aos credores de cada classe, antes de atendida a classe seguinte, parece ser mais rígido na falência; dependendo da interpretação, é possível alcançar diferentes conclusões a respeito de qual seria tal ordem. Entretanto, na recuperação judicial, o pagamento é decisão do devedor, submetida à votação nas assembléias de credores. $\mathrm{Na}$ recuperação há regras de proteção para: (i) créditos trabalhistas vencidos, pagos em até um ano, e pagamento de até cinco salários mínimos relativos aos créditos de natureza salarial, vencidos nos três meses anteriores ao pedido (art. 54); (ii) assegurar a preservação de garantias outorgadas a credores (arts. 50, §1 ${ }^{\circ} ; 59 ; 61 ; 83$ ).

A ordem de pagamento aos credores na falência e na recuperação é determinante na escolha de estratégias, pois o interesse do credor individual pela recuperação aumenta se houver maior possibilidade de receber algum valor, isto é, depende da prioridade de pagamento que lhe é atribuída. O problema poderia ser mais bem equacionado se a ordem de pagamento fosse predefinida e houvesse perfeita discriminação de classes na LREF. A questão é polêmica e depende de se saber qual a definição legal de "credor" e fixar o entendimento a respeito da necessidade de discriminação de classes, tanto na recuperação quanto na falência ${ }^{292}$.

\footnotetext{
${ }^{290}$ ROE, Mark J. Corporate reorganization and bankruptcy - legal and financial materials. University Casebook Series, New York: Foundation Press, 2000, p. 112; 123-124.

${ }^{291}$ Segundo Luiz F. V. de Paiva, a lei não prevê que deva haver tratamento igualitário na recuperação aos credores de mesma origem e natureza, indicando que credores similares podem ter tratamento diferenciado no plano. (PAIVA, Luiz F. V. de. Apresentação do plano de recuperação pelo devedor e a atuação dos credores. Revista do Advogado, ano XXV, n. 83, setembro/2005, p. 76)

${ }^{292}$ Por exemplo, Calixto Salomão Filho entende que: "Em se tratando de processo de recuperação e regras que o disciplinam, a interpretação do significado do termo credor é inteiramente diversa da que deve ser exigida para a classificação de créditos no processo falimentar. Enquanto no último as relações entre as classes é de exclusão, i.e. onde está uma a outra não pode e não deve estar, em se tratando do primeiro o princípio pode e deve ser o da inclusão." (SALOMÃO FILHO, Calixto. Recuperação de empresas e interesse social. In SOUZA JR, Francisco Satiro de; PITOMBO, Antonio Sérgio A de Moraes (coord.). Comentários à lei de recuperação de empresas e falência. São Paulo: Revista dos Tribunais, 2005, p. 49). Modesto Carvalhosa e Nilton Latorraca, comentam, a respeito do artigo 116 da LSA: "os demais acionistas, não controladores, são considerados credores e não propriamente acionistas, e é nesse sentido que a lei lhes dá proteção, notadamente ao instituir o dividendo obrigatório (art. 202)". (CARVALHOSA, Modesto; LATORRACA, Nilton. Comentários à lei de sociedades anônimas. São Paulo: Saraiva, Vol. 2, 1997, p. 426)
} 
$\mathrm{O}$ art. 58 da LREF prevê apenas a aplicação do requisito da discriminação injusta. O plano justo e equitativo não é previsto em lei, mas decisão discricionária do devedor, votada pelos credores reunidos em assembléia. A lei também não prevê o "teste do melhor interesse dos credores". A rígida divisão de classes de credores (art. 41) é inadequada para aplicação dos três conceitos sugeridos, afetando, em especial, a classe III, mais heterogênea (credores com garantia menor ou sem garantia). Nessa classe, há créditos muito diversos, o que torna difícil a tarefa de agrupar os créditos de mesma natureza para aplicar a regra da discriminação injusta.

A divisão de classes, prevista no art. 41 para a recuperação judicial, não tem correspondência com a ordem de prioridade dos créditos na falência (art. 83). Como os procedimentos legais de recuperação e falência são interdependentes, há diferentes incentivos para credores e devedores tomarem a decisão, dificultando alcançar soluções que produzam maior bem-estar coletivo.

A lei também não estabelece mecanismos independentes de revelação de informação que permitam avaliar a empresa. Ela prevê apenas a apresentação da análise da viabilidade econômica da recuperação (art. 53, II) e o laudo de avaliação de bens (art. 53, III), insuficientes para alcançar a avaliação da empresa ${ }^{293}$. A ausência de informação independente inviabiliza a consecução de dois objetivos imprescindíveis para a tomada de decisão: (i) verificar se o plano é justo e equitativo; (ii) calcular o valor de liquidação para aplicar o "teste do melhor interesse dos credores", no caso de haver credores dissidentes ${ }^{294}$. A lei, ao inviabilizar tais objetivos, não estabelece critérios para informar melhor os credores que votam em assembléia nem orienta a decisão de cramdown tomada pelo juiz.

A LREF também não incentiva a criação de mercado secundário para negociação de créditos de empresas em crise, o que dificulta a revelação de informações, reduz o interesse do mercado em financiar a empresa e diminui as

\footnotetext{
${ }^{293}$ Tema discutido na seção II.2.

${ }^{294}$ Confrontar com as sugestões propostas por: BATISTA, Carolina Soares João; CAMPANA FILHO, Paulo Fernando; MIYAZAKI, Renata Yumi; CEREZETTI, Sheila Cristina Neder. A prevalência da vontade da assembléia-geral de credores em questão: o cram down e a apreciação judicial do plano aprovado por todas as classes. Revista de Direito Mercantil, Industrial, Econômico e Financeiro, Ano XLV, n. 143, pp. 202-236, Jul./Set. 2006.
} 
possibilidades de recuperação. Tal situação obriga o devedor a propor plano de recuperação para obter recursos diretamente dos credores, porque haverá poucas formas alternativas de financiamento ${ }^{295}$.

A lei deveria criar condições para que o mercado pudesse participar da recuperação da empresa eficiente, uma vez que recuperar negócio rentável deve interessar aos investidores.

Os incentivos legais para produção de informações assimétricas podem ser corrigidos, ao menos em parte, com o uso de mecanismos de revelação de informações ${ }^{296}$ e modificações no processo de decisão assemblear ${ }^{297}$.

\section{IV.2.2. Mecanismos de revelação.}

A revelação de informações permite reduzir assimetrias de informações entre o devedor e os credores, alterando a distribuição de ganhos para os agentes. Ela pode ser realizada pelos credores, juiz, administrador judicial ou terceiros contratados para a tarefa.

A principal informação a ser revelada é o valor da empresa em crise, visto que define o interesse das partes em negociar e estabelece a referência monetária para distribuição de perdas. A revelação melhora o entendimento dos credores a respeito da expectativa sobre o montante e a probabilidade de obtenção dos valores a receber, variáveis com alto grau de incerteza que podem ser manipuladas pelo devedor.

A produção unilateral de informações por parte do devedor incentiva a adoção de comportamentos oportunistas, mas a revelação por outros agentes permite confrontar as informações produzidas, reduzindo o oportunismo e possibilitando inferir o grau de seriedade com que o devedor negocia com os credores.

\footnotetext{
${ }^{295}$ Seções III.2 e III.3.

${ }^{296}$ Seção IV.2.2.

${ }^{297}$ Seção IV.3.
} 
As informações contidas no balanço patrimonial e demonstrativos financeiros são produzidas pelo devedor e insuficientes para revelar informação aos credores, pois apresentam visão parcial da crise. Da mesma forma, o plano de recuperação, já que a lei não autoriza os credores a produzir plano alternativo nem permite a eles alterar significativamente as condições propostas pelo devedor.

Há três métodos para alcançar a revelação de informações: (i) método judicial; (ii) método de mercado; (iii) revelação direta, realizada pelas partes.

O primeiro, a revelação pelo juiz e administrador judicial, apresenta o inconveniente de que eles sabem menos a respeito do negócio que o devedor ou os credores, sendo necessário realizar ampla investigação sobre a empresa, atividade que consome tempo e recursos. Para a companhia aberta, a cotação das ações no mercado pode servir para avaliá-la ${ }^{298}$, porém, nas sociedades fechadas, é forma de difícil operacionalização.

John Caouette, Edward Altman e Paul Narayanan apontam um método para analisar o problema nas sociedades de capital fechado. Os autores propõem utilizar dados de empresas abertas do mesmo mercado e estimar o valor alcançado pela empresa não cotada em bolsa. O valor de mercado é usado como oscilante entre dois valores, o operacional e o de liquidação. Este é calculado a partir do passivo contabilizado, enquanto o valor operacional é calculado a partir do EBITDA $^{299}$, ao qual se aplica um multiplicador, em razão de variações no mercado. Quando o EBITDA é alto, o valor de mercado aproxima-se do valor operacional, e quando é baixo, aproxima-se do valor de liquidação. Os autores propõem estimar a volatilidade dos ativos da empresa, calculada em função do tamanho das vendas, mercado, especificidade e porte dos ativos. Os cálculos utilizariam dados contábeis e financeiros, declarados pela sociedade fechada, que acabam por fornecer visão unilateral do desempenho da empresa. A operacionalização da solução depende de haver dados disponíveis das empresas abertas do mesmo mercado no qual participa a sociedade fechada, que podem ser de difícil obtenção para certos setores da economia. Outro

\footnotetext{
${ }^{298}$ Seção III.2.

${ }^{299}$ Resultado antes dos impostos, juros, depreciações e amortizações.
} 
problema é que há presunção de que a empresa fechada se comporta da mesma maneira que as companhias abertas do mesmo setor, o que nem sempre ocorre ${ }^{300}$. Às vezes, a empresa pode apresentar EBITDA positivo e, ainda assim, haver crise devido à má gestão financeira $^{301}$.

A produção de laudos independentes ${ }^{302}$ pode ser uma solução, ainda que imperfeita, para revelar informações, se não evitar os “conflitos de agência” que podem surgir entre o avaliador e as partes $^{303}$. O conflito existe quando os avaliadores têm interesse na empresa em crise e agem para beneficiar a si próprios ou terceiros. Não há previsão expressa na lei para produção do laudo; há apenas referência à análise de viabilidade econômica que integra o plano de recuperação (art. 53, II e III), sem indicação de critérios para orientar a elaboração.

Outra forma de revelação judicial de informações é a contratação de auditores independentes. Para ser efetiva e evitar os conflitos de agência, a contratação deve obedecer às seguintes regras: (i) haver procedimento predefinido para a escolha do auditor; (ii) haver a possibilidade de escolher um dentre múltiplos auditores, isto é, existirem diversos prestadores de serviços com as competências necessárias para desempenhar a tarefa; (iii) o auditor deve ser independente; (iv) as regras de avaliação da empresa devem estar definidas a priori e seguir padrões aceitos pelo mercado; (v) as informações produzidas pelo auditor devem se tornar de conhecimento comum ${ }^{304}$ dos

\footnotetext{
${ }^{300}$ CAOUETTE, John B.; ALTMAN, Edward I.; NARAYANAN, Paul. Gestão do risco de crédito. Rio de Janeiro: Qualitimark, 2000, pp. 162-166.

${ }^{301}$ Lorenzo Stanghellini afirma que a Parmalat italiana entrou em crise devido à péssima gestão financeira, apesar de apresentar EBIT positivo. (STANGHELLINI, Lorenzo. Crisi di impresa fra diritto ed economia le procedure di insolvenza. Bologna: Il Mulino, 2007, p.216).

${ }^{302}$ Em relação ao Dec.-lei n. 7.661/45, Rachel Sztajn apontava a necessidade de elaboração de laudo que indicasse ao juiz elementos para avaliar a empresa no início do procedimento, para ajustar o procedimento de concordata à tutela dos mercados. (SZTAJN, Rachel. Apontamentos em matéria de empresas em crise falência e liquidação extrajudicial. In SADDI, Jairo (coord.). Intervenção e liquidação extrajudicial no sistema financeiro nacional - 25 anos da Lei 6.024/74. São Paulo: TextoNovo, 1999, p. 228)

${ }^{303}$ Conflitos de agência surgem quando indivíduos contratam terceiros (os agentes) para a realização de atividades, delegando-lhes a tomada de decisões. O conflito ocorre na presença de informação assimétrica, referindo-se aos custos incorridos quando os interesses dos agentes não estão alinhados aos do contratante. Geralmente decorre da falta de cuidado ou desídia dos agentes na execução das atividades contratadas, resultando em prejuízos para o contratante.

${ }^{304}$ Segundo a teoria dos jogos, a informação é de conhecimento comum (common knowledge) quando, em um determinado nó, a informação usada para tomada de decisão é conhecida por todos os jogadores. Para Ronaldo Fiani, há conhecimento comum quando "todos os jogadores conhecem a informação, todos os jogadores sabem que todos os jogadores conhecem a informação, todos os jogadores sabem que todos os
} 
agentes envolvidos com o procedimento concursal; (vi) a possibilidade de as partes requererem a revisão da avaliação produzida pelo auditor deve ser restrita a hipóteses definidas em lei.

A LREF não traz regras específicas para tratar o problema, sendo necessário utilizar regras similares às previstas na Lei de Sociedades Anônimas (LSA). A LREF poderia prever regras para limitar as hipóteses de pedido de revisão da avaliação elaborada pelo auditor, responsabilizando o credor ou o devedor que se utiliza do expediente para prolongar o procedimento concursal. Por exemplo, a norma do art. $4^{\circ}$, $\S 4^{\circ}$ da LSA fixa critérios de avaliação para as companhias abertas, e a do art. $4^{\circ}$-A obriga os acionistas a ressarcir a empresa se o valor da nova avaliação for inferior ao produzido pelo auditor ${ }^{305}$. Tais normas poderiam auxiliar na redução dos "atrasos estratégicos" produzidos pelo agente que não deseja o encerramento do procedimento concursal.

O segundo método é a revelação de informações realizada pelo mercado, que pode ocorrer de duas maneiras: (i) usando critérios tradicionais de avaliação de investimentos; (ii) quando se tenta vender a empresa no mercado.

jogadores sabem que todos os jogadores conhecem a informação e assim por diante, até o infinito". (FIANI, Ronaldo. Teoria dos jogos. $2^{\mathrm{a}}$ ed., São Paulo: Campus, 2006, p. 80)

${ }^{305}$ LSA, Art. $4^{\circ}(\ldots) \xi 4^{\circ}$ "O registro de companhia aberta para negociação de ações no mercado somente poderá ser cancelado se a companhia emissora de ações, o acionista controlador ou a sociedade que a controle, direta ou indiretamente, formular oferta pública para adquirir a totalidade das ações em circulação no mercado, por preço justo, ao menos igual ao valor de avaliação da companhia, apurado com base nos critérios, adotados de forma isolada ou combinada, de patrimônio líquido contábil, de patrimônio líquido avaliado a preço de mercado, de fluxo de caixa descontado, de comparação por múltiplos, de cotação das ações no mercado de valores mobiliários, ou com base em outro critério aceito pela Comissão de Valores Mobiliários, assegurada a revisão do valor da oferta, em conformidade com o disposto no art. $4^{\circ}$-A. (...)". (itálicos nossos)

LSA, Art. $4^{\circ}$-A. "Na companhia aberta, os titulares de, no mínimo, $10 \%$ (dez por cento) das ações em circulação no mercado poderão requerer aos administradores da companhia que convoquem assembléia especial dos acionistas titulares de ações em circulação no mercado, para deliberar sobre a realização de nova avaliação pelo mesmo ou por outro critério, para efeito de determinação do valor de avaliação da companhia, referido no $\S 4^{\circ}$ do art. $4^{\circ}$. $\S 1^{\circ} \mathrm{O}$ requerimento deverá ser apresentado no prazo de 15 (quinze) dias da divulgação do valor da oferta pública, devidamente fundamentado e acompanhado de elementos de convicção que demonstrem a falha ou imprecisão no emprego da metodologia de cálculo ou no critério de avaliação adotado, podendo os acionistas referidos no caput convocar a assembléia quando os administradores não atenderem, no prazo de 8 (oito) dias, ao pedido de convocação. $\S 2^{\circ}$ Consideram-se ações em circulação no mercado todas as ações do capital da companhia aberta menos as de propriedade do acionista controlador, de diretores, de conselheiros de administração e as em tesouraria. $\xi^{\circ}$ Os acionistas que requererem a realização de nova avaliação e aqueles que votarem a seu favor deverão ressarcir a companhia pelos custos incorridos, caso o novo valor seja inferior ou igual ao valor inicial da oferta pública. $\S 4^{\circ}$ Caberá à Comissão de Valores Mobiliários disciplinar o disposto no art. 40 e neste artigo, e fixar prazos para a eficácia desta revisão". (itálicos nossos) 
Os critérios tradicionais de avaliação de investimentos permitem definir a taxa mínima de atratividade do projeto, que é o custo de utilização do capital que iguala as taxas de juros praticadas pelo mercado. O investimento será atrativo se a taxa calculada superar as praticadas pelo mercado. É possível também calcular a rentabilidade simples do investimento, que é a relação entre o lucro, obtido em determinado período de tempo, e o valor total investido. Pode-se calcular, ainda, o período para retorno do investimento, o número de unidades de tempo necessárias para recuperar o capital investido. Outro indicador é o valor presente líquido, equivalente ao valor atual das entradas e saídas do fluxo de caixa derivado do projeto. Por fim, pode-se analisar a taxa interna de retorno em investir na empresa, que iguala o valor presente das entradas e saídas do fluxo de caixa do investimento; é o valor presente líquido a partir da qual o projeto torna-se atrativo para o investidor ${ }^{306}$. De acordo com os critérios apresentados, para ser atrativo para os credores ou potenciais compradores da empresa em crise, o plano de recuperação deverá demonstrar que o projeto de salvação da empresa produzirá fluxo de caixa positivo, eliminando o déficit existente.

A outra forma de revelação pelo mercado é quando se tenta vender a empresa ou os ativos no mercado. É possível revelar informações, pois são recebidas ofertas que indicam o real valor do negócio. De acordo com o estabelecido na LREF, concluímos que o momento de avaliação pode ser tardio, pois o credor deveria reconhecer a espécie de empresa com a qual está lidando desde o momento em que o devedor solicita a recuperação. Pelas regras da lei, a empresa pode ser vendida no mercado após a arrecadação dos bens (arts. 139 e 140), atividade que pode ser demorada e adiar a possibilidade de apresentação, pelos investidores interessados, de propostas que revelem o valor de mercado da empresa. Quando a arrecadação se encerrar, é possível que o procedimento concursal já esteja em estágio avançado e os agentes já tenham incorrido em custos de transação. Além disso, os potenciais compradores podem não ter interesse em ofertar preço justo, pois se beneficiam com o deságio.

O terceiro método para revelação de informações é aquele na qual as partes o

\footnotetext{
${ }^{306}$ SECURATO, José Roberto. Cálculo financeiro das tesourarias. $2^{\mathrm{a}}$ ed., São Paulo: Saint Paul Institute of Finance Editora, 2003, pp.26-33.
} 
fazem de maneira voluntária, ou por meio de incentivos criados para tal finalidade. A revelação direta é de difícil consecução, pois os agentes que detêm informação não têm interesse em revelá-la. O devedor tende a não revelar a real situação dos negócios, uma vez que a atitude melhora a posição de negociação. Os credores também usarão a informação privilegiada com o objetivo de obter maior parcela da divisão de ganhos com a recuperação. A revelação somente ocorre se a lei for "compatível em termos de incentivos" ${ }^{307}$, isto é, se a revelação for estratégia dominante para os agentes que detêm a informação.

Como a LREF não prevê sanção para o devedor que produz plano de recuperação inexeqüível, somente a revelação de informações por agentes independentes pode reduzir o oportunismo ${ }^{308}$. Uma solução possível pode ser a produção de plano de recuperação alternativo pelos credores, útil para inferir a seriedade e viabilidade da proposta original feita pelo devedor. A hipótese, entretanto, não é prevista pela lei ${ }^{309}$, e as únicas alternativas para os credores são rejeitar o plano (art. 56, $\S 4^{\circ}$ ) ou apresentar modificações com a expressa concordância do devedor (art. $\left.56, \S 3^{\mathrm{o} 310,311}\right)$. A lei também não trata o caso da empresa que tem patrimônio líquido negativo, na qual a participação do devedor no negócio é inexistente e ele, de fato, não mais participa da composição do capital da empresa. Neste caso, não há sentido em condicionar a aprovação de modificações ao plano de recuperação à concordância prévia do devedor, pois ele não deveria decidir a forma pela qual os credores decidem distribuir as perdas.

\footnotetext{
${ }^{307}$ Conceito apresentado na seção II.5.2.

${ }^{308}$ Rachel Sztajn entende que a produção de plano de recuperação por terceiros especialistas poderia ser útil para resolver o problema. (SZTAJN, Rachel. Comentários. In SOUZA JR, Francisco Satiro de; PITOMBO, Antonio Sérgio A de Moraes (coord.). Comentários à lei de recuperação de empresas e falência. São Paulo: Revista dos Tribunais, 2005, p.266)

${ }^{309}$ A lei de insolvência alemã permite que credores apresentem plano alternativo.

${ }^{310}$ Eduardo Munhoz aponta que uma das principais funções do comitê de credores nos ordenamentos estrangeiros é desempenhar papel ativo na elaboração e negociação do plano apresentado pelo devedor, inclusive com a apresentação de plano alternativo. Entende que as hipóteses previstas no art. 56, $\S 3^{\circ}$ são incompatíveis com a função social da empresa prevista na LREF e sugere que a lei deve ser alterada para permitir a modificação do plano na assembléia. (MUNHOZ, Eduardo S. Comentários. In SOUZA JR, Francisco Satiro de; PITOMBO, Antonio Sérgio A de Moraes (coord.). Comentários à lei de recuperação de empresas e falência. São Paulo: Revista dos Tribunais, 2005, pp. 276-278)

${ }^{311}$ LREF, art. 56. "Havendo objeção de qualquer credor ao plano de recuperação judicial, o juiz convocará a assembléia-geral de credores para deliberar sobre o plano de recuperação. (...) $\S 3^{\circ} \mathrm{O}$ plano de recuperação judicial poderá sofrer alterações na assembléia-geral, desde que haja expressa concordância do devedor e em termos que não impliquem diminuição dos direitos exclusivamente dos credores ausentes".
} 
É possível haver revelação de informação quando há compartilhamento do controle da empresa com os credores, mas o devedor ainda teria meios para se preparar e sonegar informações, pois conhece melhor o negócio. A LREF parece não prever expressamente a hipótese de controle externo pelos credores ${ }^{312}$, mas o caput do art. 50 permite sua utilização ${ }^{313}$. A lei prevê a possibilidade de administração compartilhada (art. 50, XIV) e situações nas quais os credores elegem administradores em separado, especificando matérias sujeitas a poder de veto no plano de recuperação (art. 50, V). A dificuldade reside no fato de que os meios de recuperação são propostos pelo devedor e este não tem interesse em compartilhar controle. Ao manter o devedor no comando absoluto dos negócios (art. 64), a lei incentiva a empresa ineficiente a não elaborar plano sério.

Se o devedor sabe mais a respeito de seu próprio negócio do que os demais agentes e não revela informações de maneira voluntária, é necessário criar método específico para incentivar sua colaboração.

Uma solução possível pode ser construir mecanismo que especifique um prêmio a ser entregue ao devedor pela colaboração, verificada em função de critério de desempenho previamente especificado e mensurada de acordo com o grau de influência direta do comportamento do devedor na melhoria das condições da empresa ${ }^{314,315}$. O prêmio pode se traduzir em qualquer vantagem, como por exemplo, concessão de prazo para cumprimento de obrigações, redução de juros, transferência de ativos, etc. O prêmio não deve prejudicar o retorno dos credores e deve ser justificado em função da honestidade e lisura do devedor, antes e durante o concurso. A adjudicação do prêmio representa o reconhecimento de um mal menor pelos credores, isto é, de que pode ser

\footnotetext{
${ }^{312}$ PENTEADO, Mauro R. Comentários. In SOUZA JR, Francisco Satiro de; PITOMBO, Antonio Sérgio A de Moraes (coord.). Comentários à lei de recuperação de empresas e falência. São Paulo: Revista dos Tribunais, 2005, p. 73.

${ }^{313}$ LREF, Art. 50. "Constituem meios de recuperação judicial, observada a legislação pertinente a cada caso, dentre outros". (itálicos nossos)

${ }^{314} \mathrm{O}$ mecanismo genérico é proposto por: PAVAN, Alessandro; CALZOLARI, Giacomo. Truthful revelation mechanisms for simultaneous common agency games. July 2007. Disponível em: $<$ http://ssrn.com/abstract=1017745>. Acesso em: 10.jun.2008, p.17.

${ }^{315}$ Lorenzo Stanghellini entende ser possível criar incentivos para o devedor colaborar com os credores. Isso se daria mediante a perspectiva de transferir ao devedor algum ganho, mesmo que nem todos os credores sejam pagos integralmente, violando a ordem de prioridade entre o capital de débito (valor pago aos credores) e o capital de risco (valor pago aos acionistas). (STANGHELLINI, Lorenzo. Proprietà i controllo dell'impresa in crisi. Rivista delle Società, Ano 49 / 2004, Set./Out. 2004, fascículo 5º p. 1080)
} 
melhor transferir pequena parcela dos ganhos obtidos com a recuperação para incentivar o devedor a colaborar, minimizando o prejuízo coletivo.

Sugerimos o seguinte método para calcular o prêmio: (i) apura-se o valor correspondente ao "teste do melhor interesse dos credores", valor mínimo a ser recebido pelos credores em caso de liquidação ${ }^{316}$; (ii) avalia-se a empresa por meio de auditores independentes; o valor obtido deve superar o valor de liquidação, para evitar a liquidação da empresa; (iii) calcula-se a diferença entre os dois valores e, com base no valor obtido, estabelece-se o prêmio a ser entregue ao devedor.

É necessário também definir o critério para apuração do grau de colaboração do devedor. Tal critério deve identificar atitudes do devedor que alterem o valor de liquidação (valor mínimo a pagar aos credores) ou o valor apurado pelo avaliador independente (valor máximo a pagar). A apuração se daria pela comparação com a estimativa dos valores que seriam obtidos sem a colaboração do devedor. O prêmio a ser pago seria proporcional ao aumento obtido em um dos dois valores, havendo, entretanto, valores máximos, estabelecidos para que o prêmio que não elimine o ganho dos credores. A LREF não prevê as hipóteses elencadas.

A empresa eficiente que não deseja ser liquidada deve preparar plano sério e comunicar a informação aos credores e ao mercado, com o objetivo de reduzir a incerteza sobre a continuidade das operações.

\section{IV.3. Decisão assemblear.}

\section{IV.3.1. Instabilidade do processo decisório.}

Já analisamos as razões pelas quais o instável mecanismo de decisão assemblear, previsto pela LREF, dificulta alcançar as decisões eficientes previstas no modelo ${ }^{317}$.

Além disso, a LREF introduz elemento presente em legislações estrangeiras: a

\footnotetext{
${ }^{316}$ Discussão na seção IV.2.1.

${ }^{317}$ Ver capítulo III e demais seções desse capítulo.
} 
possibilidade de, sob certas condições, a decisão assemblear ser modificada pelo juiz. Como os critérios adotados pela lei brasileira são insuficientes, a modificação introduz elemento de incerteza no processo decisório, agravando o quadro de instabilidade e introduzindo riscos adicionais de difícil mitigação pelos agentes.

No sistema brasileiro, a decisão assemblear pode ser modificada pelo juiz de duas maneiras: (i) direta, por meio da decretação do cramdown; (ii) indireta, computando-se a abstenção de voto dos credores como positiva. A primeira é prevista na LREF e a segunda pode ocorrer por falta de previsão legal.

Mark Roe entende que cramdown é a "última arma" do procedimento de recuperação, usado para resolver a disputa quando há rejeição do plano que deveria ter sido aprovado. O cramdown afeta as negociações porque mantém as partes receosas de que o juiz o utilize para mudar a decisão, alterando a distribuição de ganhos ${ }^{318,319}$. Serve para evitar que a minoria dissidente de credores provoque o erro do tipo II, deixar de recuperar empresa eficiente, levando-a a falência.

O juiz pode aprovar plano rejeitado (art. 58, $\S \S 1^{\circ}$ e $\left.2^{\circ}\right)^{320}$ se ocorrerem, cumulativamente, as seguintes condições: (i) o plano sofrer objeções dos credores (art. 55) ou não for aprovado na forma do art. 45; (ii) receber voto favorável de mais da metade do valor dos créditos presentes, independente de classe; (iii) o plano for rejeitado por uma classe e, nela, houver recebido voto favorável de mais de um terço

\footnotetext{
${ }^{318}$ ROE, Mark J. Corporate reorganization and bankruptcy - legal and financial materials. University Casebook Series, New York: Foundation Press, 2000, pp. 11; 372-374.

${ }^{319}$ Michelle White sustenta que o cramdown é pouco utilizado nos Estados Unidos. (WHITE, Michelle J. The corporate bankruptcy decision. In: POSNER, Richard; PARISI, Francesco, Law and Economics. Cheltenham, UK: Lyme, US: Edward Elgar Publishing, Volume III, p. 359).

${ }^{320}$ LREF, art. 58. "Cumpridas as exigências desta Lei, o juiz concederá a recuperação judicial do devedor cujo plano não tenha sofrido objeção de credor nos termos do art. 55 desta Lei ou tenha sido aprovado pela assembléia-geral de credores na forma do art. 45 desta Lei. $\S 1^{\circ} \mathrm{O}$ juiz poderá conceder a recuperação judicial com base em plano que não obteve aprovação na forma do art. 45 desta Lei, desde que, na mesma assembléia, tenha obtido, de forma cumulativa: I - o voto favorável de credores que representem mais da metade do valor de todos os créditos presentes à assembléia, independentemente de classes; II - a aprovação de 2 (duas) das classes de credores nos termos do art. 45 desta Lei ou, caso haja somente 2 (duas) classes com credores votantes, a aprovação de pelo menos 1 (uma) delas; III - na classe que o houver rejeitado, o voto favorável de mais de $1 / 3$ (um terço) dos credores, computados na forma dos $\S \S 1^{\circ}$ e $2^{\circ}$ do art. 45 desta Lei. $\S 2^{\circ}$ A recuperação judicial somente poderá ser concedida com base no $\S 1^{\circ}$ deste artigo se o plano não implicar tratamento diferenciado entre os credores da classe que o houver rejeitado".
} 
dos créditos; (iv) não previr tratamento diferenciado à classe que o houver rejeitado ${ }^{321}$.

O cramdown previsto na LREF pode ser "ameaça crível", capaz de influir na decisão dos credores, mas dificilmente ocorrerá, porque a LREF não cria condições ideais para decretação.

Explica-se. Movimento estratégico, segundo a teoria dos jogos, é ação adotada pelo jogador com o objetivo de modificar determinado aspecto do jogo, por exemplo, a ordem das jogadas ou as recompensas. "Ameaça" é promessa de adotar determinada atitude que modifica os ganhos dos jogadores e é "crível” quando há elementos para imaginar que a promessa será cumprida por aquele que a declara. A "ameaça crível" deve ser parte do "equilíbrio perfeito em subjogo", no qual ocorrem duas condições: (i) a ameaça pode ser observada pelos demais jogadores, isto é, é de pleno conhecimento de todos; (ii) a ação é irreversível, uma vez que aquele que faz a ameaça não tem incentivos para desistir de executá-la ${ }^{322}$.

O cramdown é adotado pelo juiz e, no modelo proposto, o juiz não é jogador. Ao decretá-lo, o juiz está suprindo a vontade da maioria dos credores e satisfazendo o interesse público, ao decidir que a empresa eficiente deve ser recuperada mesmo quando o plano é rejeitado. Note-se que, no caso da empresa ineficiente, o juiz não deveria decretar o cramdown, mas não há garantias de que ele não o fará, pois a lei não distingue a empresa eficiente da ineficiente.

Para ser "crível", a "ameaça" de decretação deve ser observável antecipadamente, mas ela somente se torna de conhecimento público depois de decretada pelo juiz. É provável que a informação não seja sinalizada, mas, se o for, há duas condições: (i) antes da votação, o juiz indica que decretará o cramdown se os requisitos do art. 58 forem preenchidos; (ii) a jurisprudência for favorável à decretação para casos similares e as partes acreditarem que haverá decisão segundo a tendência. São condições com baixa probabilidade de ocorrência no caso concreto, uma vez que os juízes brasileiros não costumam discutir o mérito de decisões assembleares nem

\footnotetext{
${ }^{321}$ Ver discussão na seção IV.2.1.

${ }^{322}$ FIANI, Ronaldo. Teoria dos jogos. $2^{\mathrm{a}}$ ed., São Paulo: Campus, 2006, pp. 234-235; 242; 269-270.
} 
sinalizam com antecedência as decisões tomadas.

Ainda assim, a ameaça de decretação está presente. O cramdown, uma vez decretado, não será cancelado pelo juiz. Entretanto, como ele sabe menos a respeito da empresa que o devedor ou os credores, a decretação pode se tornar decisão arriscada.

Segundo Herbert Gintis, a ocorrência de equilíbrio perfeito do subjogo é improvável na presença de informação imperfeita e incompleta, pois a informação, detida com exclusividade pelo devedor, não é revelada aos credores. Nesse tipo de jogo há muitos equilíbrios não plausíveis e poucas formas de rejeitá-los, pois os conjuntos de informação são difusos, inviabilizando a formação de subjogos perfeitos ${ }^{323}$. A aprovação do plano (art. 58 c/c 45) não é, necessariamente, uma solução, porque a votação favorável apenas confirma o interesse coletivo dos credores, mas não garante que somente empresas eficientes sejam recuperadas.

O cramdown é "ameaça crível" se as seguintes condições ocorrem: (i) a empresa é eficiente e deve ser recuperada (equilíbrio perfeito em subjogo); (ii) o juiz sinaliza, com antecedência, a possibilidade de decretação; (iii) não há incentivos para deixar de decretar o cramdown; (iv) os requisitos do art. 58 estão presentes.

O cramdown também pode levar a resultados injustos, uma vez que ocorrerá muito depois de iniciado o procedimento, permitindo que o devedor da empresa ineficiente retenha parte dos ganhos a que não faz juz ${ }^{324}$. Pode haver também empresas

\footnotetext{
${ }^{323}$ GINTIS, Herbert. Game theory evolving - A problem-centered introduction to modeling strategic interaction. Princeton: Princeton University Press, 2000, p. 286.

324 "Imagine que o plano proponha distribuir para a classe de credores sem garantia bens de valor igual ou valor do capital principal da dívida mais juros computados desde o pedido de recuperação. Imagine também que o plano preveja que os acionistas também recebam remuneração paga pelo devedor. Este plano deve ser confirmado mesmo com a objeção dos credores com garantia de que a classe dissidente de credores está recebendo bens de valor igual ao total da dívida? O montante permitido não deveria (...) incluir juros posteriores à concessão da recuperação; entretanto, o plano parece estar em conformidade com as regras legais. Por isso, o cramdown (...) pode produzir o mesmo resultado desigual (...); O devedor pode reter parte dos ganhos ou os acionistas podem reter ganhos pagos pelo devedor, enquanto os credores com garantia não receberão pagamento de acordo com o estabelecido em contrato". (ROE, Mark J. Corporate reorganization and bankruptcy - legal and financial materials. University Casebook Series, New York: Foundation Press, 2000, pp. 373-374)
} 
eficientes utilizando-o para obter maiores descontos para as dívidas ${ }^{325}$.

Outra maneira de aprovar o plano de recuperação é computar as abstenções de voto em assembléia como votos favoráveis ao plano. É forma indireta de modificação do resultado da votação, mas depende de interpretação dos dispositivos legais. Como a LREF nada dispõe a respeito, o voto do credor ausente pode ser computado como positivo e, se a nova contagem de votos for suficiente para atingir o quorum de aprovação exigido, o plano terá sido confirmado pelos credores sem necessidade de recorrer ao cramdown.

A doutrina e a jurisprudência indicam dois sentidos possíveis para a interpretação da ausência do credor em assembléia. Em sentido negativo, a abstenção pode significar rejeição com base no art. $45, \S 1^{\circ}$ da LREF, que determina que o plano seja aprovado pela maioria dos presentes à assembléia. A abstenção significa desinteresse pelo acordo de salvação e equivale ao voto contrário à recuperação. Em sentido positivo, a abstenção significa aprovação, justificada pela regra do art. 129 da LSA, que estabelece que não sejam computados os votos em branco nas deliberações tomadas por maioria absoluta. De acordo com tal ponto de vista, o credor é indiferente ao resultado da votação, mas se abstém de votar com a intenção de não se comprometer, reduzindo a exposição a riscos, no caso de a falência ser decretada. Assim, a indiferença autoriza o intérprete a aplicar o princípio da preservação da empresa (arts. $\left.47 ; 58, \S 1^{\circ}\right)$, alcançando a manutenção do acordo de salvação da empresa. A interpretação sugere que a recuperação é "contrato" entre devedor e credores e, quando há ambigüidade, deve-se interpretar a abstenção de voto no sentido mais conveniente à natureza do contrato. Segundo tal interpretação, a manutenção do "contrato de recuperação" implica na preservação da empresa e dos empregos, e também na possibilidade de os credores receberem algum valor. A rejeição, por sua vez, faz desaparecer a empresa e torna o acordo sem efeito, contrariando a própria função do

\footnotetext{
${ }^{325}$ Confrontar com as sugestões para modificação da lei concursal com vistas a minimizar o problema do cramdown em: BATISTA, Carolina Soares João; CAMPANA FILHO, Paulo Fernando; MIYAZAKI, Renata Yumi; CEREZETTI, Sheila Cristina Neder. A prevalência da vontade da assembléia-geral de credores em questão: o cram down e a apreciação judicial do plano aprovado por todas as classes. Revista de Direito Mercantil, Industrial, Econômico e Financeiro, Ano XLV, n. 143, pp. 202-236, Jul./Set. 2006.
} 
contrato $^{326,327}$.

Discordamos das duas interpretações, pois a abstenção não significa nem uma coisa nem outra. A abstenção pode indicar que o credor sugere haver uma terceira alternativa, ou que as opções apresentadas em assembléia são inadequadas para resolver o problema.

A interpretação em sentido positivo sugere que o plano de recuperação é contrato previamente estabelecido, o que não se sustenta. A votação em assembléia serve para decidir a validade da proposta de contrato de financiamento da empresa (plano de recuperação). A manifestação de aceitação do contrato é essencial para sua formação e o silêncio não pode ser interpretado como adesão tácita ${ }^{328}$. A $\operatorname{argumentação~}$ de que o desaparecimento da empresa elimina os efeitos da decisão também é desprovida de coerência, pois o objetivo da falência é realocar os ativos da empresa insolvente para empreendimentos mais produtivos.

Pelas mesmas razões expostas, a interpretação em sentido negativo também não pode associar a abstenção de voto a desinteresse pelo acordo. O acordo (plano aprovado) é o “resultado” da votação, não podendo ser utilizado para interpretar os efeitos decorrentes da abstenção. Relembrando Mark Roe ${ }^{329}$, votação justa interpreta-se por meio de regras de votação "previamente estabelecidas”, não pelo resultado obtido.

O cômputo de abstenções de voto, assim como a possibilidade de decretação do

\footnotetext{
${ }^{326}$ A jurisprudência oscila entre as duas possibilidades. Ver: proc. n. 583.00.2005.068090-1, $1^{\text {a }}$ Vara de Falência e Recuperações Judiciais de São Paulo, 21/12/2005, Parmalat Brasil S/A Indústria de Alimentos; proc. n. 583.00.2005.070715-0, 1 a Vara de Falência e Recuperações Judiciais de São Paulo, 28/08/2006, VASP - Viação Aérea São Paulo Sociedade Anônima.

${ }^{327}$ Ver também (Câmara Especial de Falências e Recuperações Judiciais; Agravo de Instrumento $\mathrm{n}^{\circ}$

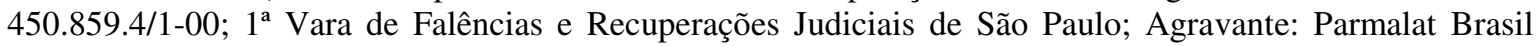
S.A. Indústria de Alimentos (em recuperação judicial); Agravado: Deutsche Trustee Company Limited): "Agravo de Instrumento. Recuperação Judicial. Assembléia-Geral de Credores. Apuração do resultado da votação do plano de recuperação judicial ou de proposta de deliberação assemblear. Credor que comparece e, tendo o direito de votar, abstém-se de efetivamente votar favorável ou contrariamente. Crédito do abstinente que não deve ser levado em consideração para a apuração do resultado. Créditos presentes à Assembléia devem ser considerados aqueles dos credores presentes e que efetivamente votaram, positiva ou negativamente. Aplicação analógica do artigo 129, "caput", da Lei das S/A. Agravo provido." "O crédito do credor que comparece à Assembléia-Geral de credores, mas, se abstém de votar, vale dizer, não vota favorável ou contrariamente, não deve ser considerado para o cômputo do quorum de aprovação do plano." ${ }^{328}$ Nesse sentido, ver: BOITEUX, Fernando Netto. Contratos mercantis. São Paulo: Dialética, 2002, p. 38 ${ }^{329}$ Seção IV. 2.1.
} 
cramdown, introduzem elemento de incerteza no processo decisório. O credor pode ser indiferente ou interessado, independente de se abster de votar. $\mathrm{O}$ indiferente pode estar ausente, mas também pode comparecer sem se manifestar. $\mathrm{O}$ interessado pode estar presente e votar, ou pode estar ausente e utilizar estratégia de não votar. A mera ausência não autoriza o intérprete a concluir que há desinteresse pela votação, pois o credor pode, com sua ausência, querer indicar que há outras formas de resolver o problema, distintas das apresentadas em assembléia. Abstenção significa apenas opção pela estratégia de não votar, questionando as opções oferecidas ${ }^{330}$. O argumento é reforçado pela regra que estabelece que, ao credor ausente, ou àquele que se absteve de votar, atribui-se o direito de anular a deliberação assemblear ${ }^{331}, 332$.

Do ponto de vista de teoria dos jogos, as interpretações sugeridas pela doutrina e pela jurisprudência aumentam a instabilidade do processo decisório, pois modificam as regras do jogo depois que as decisões foram tomadas. Por causa da falta de previsão legal, a questão depende de interpretação jurisprudencial, tornando a estratégia de abstenção arriscada para o credor e a votação do plano uma deliberação que depende de confirmação pelo juiz. Essa situação aumenta a incerteza sobre a distribuição de ganhos e introduz riscos não sistemáticos de difícil controle pelo procedimento concursal.

\section{IV.3.2. Mecanismos de estabilização.}

Segundo a LREF, as assembléias que votam o plano de recuperação são realizadas de forma seqüencial e com comunicação de informações, iniciando a votação

\footnotetext{
${ }^{330}$ No mesmo sentido, Rachel Sztajn entende que a abstenção pode indicar que o credor não foi convencido com os argumentos apresentados no plano, ou acredita que pode haver outras soluções para o problema. (SZTAJN, Rachel. Notas sobre as assembléias de credores na lei de recuperação de empresas. Revista de Direito Mercantil, Industrial, Econômico e Financeiro, Ano XLIV, n. 138, abr./jun. 2005, p. 57)

${ }^{331}$ Erasmo França explica que o credor que votou contra o plano e o ausente têm legitimação ativa para anular assembléia geral ou invalidar as deliberações na LREF. (FRANÇA, Erasmo Valladão de A. e N. Comentários. In SOUZA JR, Francisco Satiro de; PITOMBO, Antonio Sérgio A de Moraes (coord.). Comentários à lei de recuperação de empresas e falência. São Paulo: Revista dos Tribunais, 2005, p. 195)

${ }^{332}$ Priscila Fonseca explica que aquele que deixou de votar pode ser o que não compareceu ou aquele que, estando presente, deixou de votar. Ambos, para efeito de legitimação, se equiparam àquele que votou contra a deliberação tomada por maioria. A autora explica que, como se concede direito de impugnar a deliberação a quem votou a favor, provando tê-lo feito de forma viciada, deve-se deferir igual direito ao ausente, parecendo rigoroso demais assumir que a recusa é adesão tácita, pois o silêncio pode derivar de fatores estranhos à vontade, não de indiferença. $\mathrm{O}$ que se abstém de votar não aprova nem desaprova a deliberação, e o silêncio não pode significar nem uma coisa nem outra, sendo irrelevantes os motivos da abstenção.(FONSECA, Priscila C. da. Suspensão de deliberações sociais. São Paulo: Saraiva, 1986, pp. 89-91)
} 
pelos trabalhadores (classe I), seguida dos credores com garantia real (classe II) e com garantia menor ou sem garantia (classe III) ${ }^{333}$.

As regras legais podem tornar instável o processo de decisão assemblear, produzindo resultados imprevisíveis, porque não são respeitadas as condições mínimas de estabilização: (i) não há homogeneidade das classes de credores, consideradas individualmente, e também não há heterogeneidade entre as classes de credores, consideradas umas em relação às outras; (ii) as assembléias não são realizadas de forma simultânea e há possibilidade de comunicação de informação entre as assembléias; (iii) a informação utilizada para decisão não é completa; (iv) as decisões tomadas em assembléia podem ser modificadas pelo juiz.

Uma classe é homogênea se há alinhamento de preferências (interesses) entre os membros da classe, isto é, o melhor resultado para a classe é também o preferido pelo indivíduo ${ }^{334}$. A rígida divisão de classes prevista no art. 41, combinada com a inexistência de regras para formação e tratamento diferenciado de subclasses de credores, permite concluir que as classes previstas na lei não são homogêneas para a maioria das situações ${ }^{335}$. Na classe I (credores trabalhistas e por acidente de trabalho), não há homogeneidade necessária, porque a lei unificou o tratamento dado aos créditos de natureza trabalhista e aos por acidente de trabalho ${ }^{336}$, mas não há garantias de que os credores trabalhistas e os por acidente do trabalho se comportarão da mesma maneira.

Na classe II (credores com garantia), a homogeneidade pode depender do tipo de garantia detida e da interdependência entre as garantias outorgadas a distintos credores. Assim, por exemplo, se dois credores detêm garantias que somente têm valor de mercado se vendidas em conjunto, pode haver convergência de interesses. Ao contrário, pode haver garantias dadas a credores distintos que concorrem pela realocação no mesmo mercado, isto é, se uma for vendida antes da outra, a segunda terá

\footnotetext{
${ }_{333}^{333}$ Seção III.3.

${ }^{334}$ BAROSSI FILHO, Milton. As assembléias de credores e plano de recuperação de empresas: uma visão da teoria dos jogos. Revista de Direito Mercantil, Industrial, Econômico e Financeiro, Ano XLIV, n. 137, jan./mar. 2005, p. 234.

${ }^{335} \mathrm{O}$ desalinhamento entre a divisão de classes dos arts. 26 (comitê de credores) e 41 (assembléias de credores) da lei também parece sugerir a mesma conclusão.

${ }^{336}$ A nova redação do art. 114 da Constituição Federal, alterado pela Emenda n. 45/2004, passou a submeter esses créditos à justiça trabalhista.
} 
valor reduzido porque o mercado não comporta a realocação de ambas. Neste caso, pode haver desalinhamento entre os interesses.

Por fim, na classe III (credores com garantia menor e sem garantia), há maior variabilidade, porque essa classe combina credores de diversas naturezas e distintos interesses ${ }^{337}$.

A heterogeneidade de classes significa, por sua vez, que as preferências de uma classe não devem se confundir com as da outra, isto é, os interesses podem estar alinhados na classe, mas são distintos do interesse das demais classes. Segundo a LREF, o credor vota na classe II pelo valor do bem dado em garantia, e, na classe III, pelo saldo remanescente (art. $41, \S 2^{\circ}$ ). Nesse caso, pode haver transitividade de preferências de uma classe para outra.

Segundo a lei, as assembléias não são realizadas de forma simultânea, havendo possibilidade de comunicação de informação durante a realização. Se fossem simultâneas, o jogo poderia ser de informação completa. Os credores de uma classe teriam que votar sem saber o resultado da deliberação das demais assembléias e considerariam apenas os próprios interesses, internalizando os custos da decisão. Para tornar as três assembléias simultâneas, cada uma deveria ser presidida por um agente diferente, por exemplo, o administrador judicial, o juiz e outro auxiliar da justiça, e o momento das votações deveria ser sincronizado para minimizar a comunicação. A LREF, entretanto, indica que todas as assembléias devem ser presididas pelo administrador judicial (art. 37), obrigando-as a serem realizadas em seqüência.

A redação do art. 41 da LREF permite supor que as assembléias devem ser realizadas na ordem em que as classes de credores são apresentadas no artigo, podendose inferir que os trabalhadores votam primeiro (classe I), seguidos pelos credores com garantia real (classe II) e demais credores (classe III). Tal ordem legal prejudica os trabalhadores $^{338}$. O paradoxo de Condorcet, importante limitação da teoria da escolha racional, indica que a ordem das votações, se alterada, faz com que, muitas vezes, a

\footnotetext{
${ }^{337}$ Ver discussão detalhada no capítulo III.

${ }^{338}$ Ver detalhamento na seção III.3.
} 
decisão coletiva não represente o conjunto de preferências individuais dos agentes. $\mathrm{O}$ Marquês de Condorcet, no século XVIII, percebeu que as preferências coletivas podem ser cíclicas, isto é, não transitivas, e que o mesmo pode ocorrer com as preferências individuais.

A informação utilizada para decisão nas assembléias deve ser completa e conhecida de todos os participantes, situação que não pode ser alcançada com as regras legais existentes. Já se analisaram as razões porque a lei não realiza a revelação de informações, tornando-as de conhecimento comum dos agentes ${ }^{339}$.

Por fim, é imprescindível que as decisões tomadas em assembléia sejam respeitadas, confirmando a distribuição de ganhos definida na votação do plano de recuperação. Já discutimos o problema da modificação da decisão assemblear, demonstrando ser necessário ajustar as hipóteses legais para minimizar o receio dos agentes de que haja alteração forçada dos ganhos estabelecidos em assembléia ${ }^{340}$.

Como a LREF não dá indicações claras ao juiz sobre que aspectos do procedimento concursal podem ser modificados, o risco de intervenção insuficiente ou exagerada pode tornar o processo decisório instável. Não se espera que o juiz seja mero homologador do procedimento, mas a lei deveria fornecer parâmetros para balizar sua atuação $^{341}$. Por exemplo: permitir ao juiz excluir certos indivíduos das votações com vistas a tornar as classes mais homogêneas; ajustar as assembléias para impedir o alinhamento das votações; ampliar a revelação de informações. Tais aspectos não são detalhados em nosso trabalho.

\section{IV.4. Efeitos de segunda ordem.}

A questão é complexa e é abordada de maneira resumida.

\footnotetext{
${ }^{339}$ Seção IV.2.2.

${ }^{340}$ Seção IV.3.1.

${ }^{341}$ Nesse sentido: PENTEADO, Mauro R. Comentários. In SOUZA JR, Francisco Satiro de; PITOMBO, Antonio Sérgio A de Moraes (coord.). Comentários à lei de recuperação de empresas e falência. São Paulo: Revista dos Tribunais, 2005, pp. 70-71).
} 
Pode-se definir efeito de segunda ordem como o conjunto de conseqüências indiretas que afetam indivíduos que não participam diretamente das decisões.

O tema parte de uma questão principal: saber se o procedimento concursal deve proteger os credores e a comunidade (pessoas) ou assegurar créditos (bens). A regra geral é estabelecer-se a proteção aos créditos, independente de quem os detenha, mas pode haver casos em que o credor ou a sociedade civil devam ser objeto de proteção. Os exemplos mais comuns referem-se à proteção aos consumidores, credores trabalhistas e pequenos fornecedores que dependem da cadeia produtiva organizada em torno da empresa em crise.

O problema depende de saber se há capacidade de o credor proteger os próprios interesses: há credores bem informados e capazes de se defenderem, e credores pouco sofisticados que necessitam de tutela.

Imagine-se o seguinte exemplo de credores: um empregado celetista que detém créditos de pequeno valor, mas depende dos rendimentos de salário para sobreviver; um ex-funcionário que se desligou da empresa para prestar serviços a ela (terceirização). O primeiro é credor trabalhista e recebe proteção especial da lei ${ }^{342}$, mas o segundo é, com freqüência, credor quirografário, fornecedor de serviços com baixa prioridade de recebimento dos créditos. A lei dá tratamento diferenciado aos créditos do primeiro, mas não protege da mesma forma o segundo.

Outro problema é o efeito multiplicador sobre a cadeia produtiva da indústria na qual atua a empresa. Os credores que dependem da cadeia produtiva organizada em torno da empresa em crise podem ter interesse na preservação desta, pois garantem a demanda futura para os próprios produtos e serviços. $\mathrm{O}$ desaparecimento da empresa pode fazer desaparecer as empresas criadas em função desta, razão pela qual a tutela do mercado ganha importância, pois objetiva a proteção da comunidade e dos

\footnotetext{
${ }^{342}$ Tratado na seção III.3.
} 
consumidores, não do interesse individual ou coletivo dos credores $^{343}$.

Adriana Gardino relata que, no caso da Parmalat Brasil, a suspensão da atividade produtiva da empresa afetou milhares de credores-fornecedores, muitos deles pequenos produtores de leite cuja subsistência dependia da realização de negócios com a empresa. Aponta que havia pequenos municípios na Região Sul do país cuja comunidade se formou em torno das fábricas de beneficiamento de leite e que entraram em crise quando a empresa deixou de honrar compromissos assumidos. A autora relata haver, à época, decisões judiciais liminares desapossando a Parmalat das instalações com concomitante nomeação de administrador judicial para dar continuidade aos negócios, com o objetivo de pagar fornecedores ${ }^{344}$. Boa parte da comunidade formada nesses municípios não era credora direta da Parmalat, mas foi afetada pela crise.

Rachel Sztajn entende que o fundamento da intervenção extrajudicial ${ }^{345} \mathrm{em}$ instituições financeiras para prevenir, controlar e resolver a crise reside na tutela de poupadores, depositantes e aplicadores que, acreditando na solidez de instituições que deveriam zelar pela guarda e manutenção dos recursos, podem ser deles despojados em virtude de gestão temerária ${ }^{346}$. Trata-se de proteção à poupança popular, aplicável a outros setores que captam recursos da mesma maneira, como por exemplo, as construtoras e incorporadoras de imóveis. Entretanto, o regime de intervenção e

\footnotetext{
${ }^{343}$ SZTAJN, Rachel. Comentários. In SOUZA JR, Francisco Satiro de; PITOMBO, Antonio Sérgio A de Moraes (coord.). Comentários à lei de recuperação de empresas e falência. São Paulo: Revista dos Tribunais, 2005, p. 221.

${ }^{344}$ Adriana Gardino explica que a crise da filial brasileira da Parmalat foi derivada da crise da matriz italiana, decorrentes de múltiplos fatores, inclusive fraudes perpetradas pelos controladores, atingindo as empresas brasileiras do grupo. Estas ingressaram com concordata suspensiva, suspensa liminarmente até $2004 \mathrm{em}$ função de medida cautelar proposta por bancos credores com o objetivo de preservar o patrimônio da devedora, resguardar interesses dos credores e garantir bens para a futura execução. Os objetivos principais da medida cautelar eram afastar os controladores da empresa e evitar a alienação de bens e a transferência de ativos das empresas brasileiras para a matriz italiana (GARDINO, Adriana V. P. A evolução do tratamento jurídico da empresa em crise no direito brasileiro. Dissertação de Mestrado. São Paulo: Faculdade de Direito da Universidade de São Paulo, 2006, pp.43; 63-65). A concordata iniciada sob a égide da lei anterior foi convertida em recuperação judicial, segundo as regras da nova lei $\left(\operatorname{art.} 192, \S 2^{\circ}\right)$. O plano de recuperação apresentado pela empresa previa, entre outras medidas, a preservação do valor da companhia, sua capitalização, licenciamento de marcas, definição de um novo acionista controlador e alocação de fluxo de caixa para pagar os credores com prioridade para os credores-fornecedores (informações sobre o plano de recuperação disponíveis em: <www.parmalat.com.br>, acesso em 01.06.2006).

${ }^{345}$ Regime de intervenção e liquidação extrajudicial de instituições financeiras, Lei n. 6.024/74 e Lei n. 9.447/97.

${ }^{346}$ SZTAJN, Rachel. Apontamentos em matéria de empresas em crise - falência e liquidação extrajudicial. In SADDI, Jairo (coord.). Intervenção e liquidação extrajudicial no sistema financeiro nacional - 25 anos da Lei 6.024/74. São Paulo: TextoNovo, 1999, p. 219.
} 
liquidação extrajudicial aplica-se tão somente às instituições financeiras e assemelhadas, enquanto às empresas aplica-se a LREF, que nada dispõe a respeito.

Rachel Sztajn aponta exemplos para auxiliar a avaliação dessas situações, ainda sob a égide da legislação falimentar anterior. De um lado, o caso da construtora Encol, situação típica de captação de poupança popular, na qual os credores eram pessoas físicas adquirentes de unidades condominiais com baixa capacidade de se defenderem. De outro lado, a rede de varejo G Aronson, na qual os credores eram grandes empresas com condições de se protegerem. Na análise da concordata do Decreto-Lei n. 7.661/45, a autora apontava a necessidade de distinguir entre o comerciante que capta poupança popular com a promessa de venda ou entrega futura de bens e o produtor direto de bens no mercado ${ }^{347}$.

A LREF, da mesma forma que o Decreto-Lei anterior, não estabelece normas para lidar com o problema. Não há tutela preventiva dos consumidores e poupadores no sistema da nova lei.

O problema das insolvências internacionais também não é tratado pela LREF. É possível imaginar um grupo empresarial multinacional transferindo ativos da filial para a matriz para cobrir prejuízos ou preservar ativos da falência. Além disso, a lei concursal brasileira não tem força atrativa para abranger o grupo. É possível supor que a devedora ou os credores tentem escolher a lex fori concursus, optando pela lei que lhes for mais favorável ${ }^{348}$. Se determinada jurisdição favorece os administradores e o devedor, e outra favorece os credores, então a decisão de falência ou recuperação pode ser distinta, dependendo de qual agente dá início ao procedimento concursal. Imagine uma empresa em crise na Espanha cuja filial no Brasil não esteja em crise. Se a lei brasileira lhe for mais favorável, bastará à matriz realizar a transferência de ativos da

${ }^{347}$ SZTAJN, Rachel. Apontamentos em matéria de empresas em crise - falência e liquidação extrajudicial. In SADDI, Jairo (coord.). Intervenção e liquidação extrajudicial no sistema financeiro nacional - 25 anos da Lei 6.024/74. São Paulo: TextoNovo, 1999, p. 223-228.

348 ENRIQUES, Luca; GELTER, Martin. How the old world encountered the new one: regulatory competition and cooperation in European corporate and bankruptcy law. European Corporate Governance Institute (ECGI), Working Paper Series in Law, n. 63/2006, February 2006. Disponível em <http://ssrn.com/abstract=887164>. Acesso em: 06.ago.2007, pp.52-60; LABOVITZ, M. Natasha; BASIL, Jessica I. It's a small world after all: a survey of recent developments in US Bankruptcy Law and their potential multinational impact. Business Law International, v. 7, n. 1, pp. 39-52, January 2006. 
filial e, depois, submetê-la a concurso.

Tais situações podem fazer com que a empresa eficiente seja forçada pelo controlador do grupo a se tornar ineficiente para que os administradores e o devedor possam se valer dos benefícios do procedimento concursal de outro país. Há regras de direito societário que permitem minimizar o problema da transferência de ativos sem contrapartida, entretanto, como já discutimos anteriormente (capítulo III), há meios de o devedor realizar transferências sem incorrer em fraude.

A análise dos efeitos de segunda ordem é tema complexo que depende de múltiplos fatores, devendo combinar técnicas para gestão de risco de crédito e gestão de risco de mercado.

A gestão do risco de crédito utiliza técnicas de análise de fluxo de caixa e avaliação de riscos fora do balanço que permitem analisar as características da empresa e do mercado, razões da crise, demonstrativos financeiros, fluxo de caixa, capacidade de pagamento, estrutura do setor, capacitação dos administradores, estratégia operacional, garantias dadas aos empréstimos, formas de securitização de dívidas ${ }^{349}$.

A gestão de risco de mercado analisa a possibilidade de determinado negócio sofrer alterações de valor como resultado de forças de mercado. Envolve questões como regulamentação, mudanças tecnológicas, preferências de consumidores, proteção ao meio ambiente, impacto sobre a força de trabalho, bem como o efeito multiplicador da quebra de elo da cadeia produtiva da empresa ${ }^{350}$.

${ }^{349}$ CAOUETTE, John B.; ALTMAN, Edward I.; NARAYANAN, Paul. Gestão do risco de crédito. Rio de Janeiro: Qualitimark, 2000, pp.95-107; 117-126.

${ }^{350}$ CAOUETTE, John B.; ALTMAN, Edward I.; NARAYANAN, Paul. Gestão do risco de crédito. Rio de Janeiro: Qualitimark, 2000, pp.1-2; SECURATO, José Roberto. Cálculo financeiro das tesourarias. $2^{\mathrm{a}}$ ed., São Paulo: Saint Paul Institute of Finance Editora, 2003, p.340. 


\section{Apêndice: formulação matemática do modelo ${ }^{351}$.}

\section{Premissas e variáveis.}

O jogo se desenvolve em três estágios. O primeiro refere-se à decisão do devedor em estabelecer negociação privada com os credores. O segundo estágio, que somente ocorre se o primeiro não for bem sucedido, refere-se à decisão do devedor de requerer a falência ou propor a recuperação. Caso opte pela recuperação, poderá pagar percentual significativo dos créditos ou tentar barganhar com proposta de pagamento insuficiente. O terceiro estágio é a decisão final dos credores em aceitar o plano proposto pelo devedor, tomada em assembléia geral.

O jogo inicia com a probabilidade de saber se a empresa é eficiente, evento da natureza ${ }^{352}$ observado apenas pelo devedor. A introdução do evento é necessária porque não há dados empíricos para testar as hipóteses.

Roger Myerson explica que, em jogos seqüenciais, a introdução de eventos da natureza, mesmo que com baixa probabilidade de ocorrência, altera os resultados do jogo porque, quando há evento de probabilidade zero, as crenças dos jogadores restringem-se àquelas consistentes com a estrutura do jogo. Agregar o evento de baixa probabilidade significa adicionar um novo ramo à árvore de decisão, ampliando as crenças. Esse ramo pode afetar o conjunto de equilíbrios do jogo, porque equivale a assumir que os jogadores revisarão as crenças no futuro. A distinção se dá entre evento impossível e evento de probabilidade baixa, uma vez que se deve admitir a possibilidade de o jogador ser irracional ou jogar no ramo errado. Com a introdução do evento, a hipótese torna-se possível, porém improvável ${ }^{353}$.

Esse tipo de probabilidade é utilizado antes da coleta de amostras estatísticas, sendo, muitas vezes, subjetiva e baseada em juízos pessoais e informações históricas,

\footnotetext{
${ }^{351}$ Esse capítulo descreve a formulação matemática do modelo apresentado no capítulo III.

${ }^{352}$ Evento é acontecimento incerto que desejamos conhecer melhor. O evento pode ser produzido pelo comportamento dos agentes ou pode ser de autoria desconhecida, incerta ou de terceiros (evento da natureza). ${ }^{353}$ MYERSON, Roger B. Game Theory - analysis of conflict. Cambridge: Harvard University Press, 1991, pp. 187-190.
} 
podendo, ou não, ser confirmada pelos dados coletados. A principal diferença entre o procedimento estatístico clássico (teste de hipóteses) e o bayesiano é o uso da informação subjetiva na análise da decisão e na avaliação de conseqüências. Enquanto os procedimentos clássicos baseiam-se na análise de dados coletados em amostras aleatórias, os bayesianos não dependem da disponibilidade prévia de dados ${ }^{354}$.

Como se trata de jogo seqüencial, a configuração é de jogo com equilíbrio bayesiano perfeito, no qual há dependência entre as conclusões e as crenças do modelo, restritas, neste caso, à probabilidade de ocorrência do evento da natureza. O conceito bayesiano, ou do valor esperado, é distinto do usado no Teorema de Bayes (probabilidade condicional), porque aquele serve para examinar as probabilidades do evento. A melhor estratégia identificada pelo critério do valor esperado é a de menor perda de oportunidade, ou menor arrependimento ${ }^{355}$.

A configuração do jogo bayesiano permite que o jogador se utilize de soluções pré-definidas para simplificar a resolução do problema. Herbert Gintis explica que o conceito bayesiano mostra que o equilíbrio deve ser imune a baixas probabilidades de erro na escolha de estratégias pelos jogadores. Em outras palavras, é caso limite quando há pouca chance de erro na escolha de estratégias. Por causa dos altos custos para identificar e analisar eventos com baixa probabilidade, e também pela utilização incorreta dos dados, os jogadores preferem utilizar um conjunto de contextos situacionais que permitem resolver o problema ${ }^{356}$.

O modelo analisa o binômio "partes em conflito, objeto do conflito", no qual as partes são o devedor e os credores e o objeto é a empresa em crise.

Definimos dois momentos de análise: (i) período 1, quando se decide pela recuperação ou liquidação; (ii) período 2, quando os resultados são avaliados.

\footnotetext{
${ }^{354}$ KASMIER, Leonard J. Estatística aplicada à Economia e Administração. São Paulo: Makron Books, 1982, pp. 259; 289.

355 Ibid, p. 240.

${ }^{356}$ GINTIS, Herbert. Game theory evolving - A problem-centered introduction to modeling strategic interaction. Princeton: Princeton University Press, 2000, pp. 90-92.
} 
Em relação à incerteza a respeito da perspectiva de ganhos futuros da empresa em crise, há duas hipóteses: (i) quando os ganhos obtidos com a continuação dos negócios ${ }^{357}$ são conhecidos e mensuráveis; (ii) quando os ganhos não são conhecidos.

Os jogadores são: (i) devedor, que pode ser uma coalizão entre o falido, administradores, controladores e credores que financiam a continuação do negócio; (ii) credores, divididos em três classes, supostamente homogêneas: trabalhistas e por acidente do trabalho (classe I), com garantia real (classe II) e com garantia menor e sem garantia (classe III).

Apresentamos os resultados pelo método do valor presente, não havendo necessidade de aplicar taxas de desconto ${ }^{358}$ para comparar os valores apresentados.

As equações utilizam as seguintes variáveis:

\begin{tabular}{|l|}
\hline p: probabilidade de a empresa ser eficiente - evento da natureza. \\
\hline r: probabilidade de a empresa obter o ganho "R" no período 2. \\
\hline $\mathbf{D}_{\mathbf{1}}$ : débitos no período 1 anteriores ao pedido de falência ou \\
recuperação judicial. \\
\hline $\mathbf{D}_{\mathbf{2}}$ : débitos no período 2 posteriores ao pedido de recuperação \\
judicial. \\
\hline $\mathbf{D}_{\mathbf{P}}$ : valor das dívidas perdoadas, ou negociadas. \\
\hline $\mathbf{D}_{\mathrm{NP}}$ : valor das dívidas não perdoadas, ou a pagar. \\
\hline $\mathbf{F}_{\mathbf{1}}$ : empréstimo obtido, pelo devedor, no período 1 , diretamente \\
dos credores ou do mercado; usado para cobrir o valor de $\mathrm{D}_{1}$. \\
\hline $\mathbf{R}_{\mathbf{D}}$ : ganho total obtido pelo devedor. \\
\hline $\mathbf{R}_{\mathbf{C}}$ : ganho total obtido pelos credores. \\
\hline $\mathbf{R}:$ variação de ganhos para o devedor. \\
\hline $\mathbf{L}:$ valor de liquidação da empresa no período 1. \\
\hline
\end{tabular}

${ }^{357}$ O modelo não distingue as hipóteses de continuação do negócio na falência (art. 99, XI) e continuação das atividades prevista no art. 48 da LREF (recuperação judicial). A respeito da primeira, ver: Nelson Abrão, $A$ continuação do negócio na falência. $2^{\text {a }}$ ed., São Paulo: LEUD, 1998.

${ }^{358}$ A taxa de desconto é usada para trazer a valor presente um determinado valor apresentado no futuro. 


\begin{tabular}{|l|}
\hline $\mathbf{V}_{\mathbf{F 1}}:$ valor de face dos créditos para a classe 1. \\
\hline $\mathbf{V}_{\mathbf{F} 2}:$ valor de face dos créditos para a classe 2. \\
\hline $\mathbf{V}_{\mathbf{F 3}}:$ valor de face dos créditos para a classe 3. \\
\hline t: percentual de recuperação dos créditos para a classe 1. \\
\hline s: percentual de recuperação dos créditos para a classe 2. \\
\hline $\mathbf{u}:$ percentual de recuperação dos créditos para a classe 3. \\
\hline C: custos de transação totais. \\
\hline
\end{tabular}

\section{Hipóteses.}

No quadro-resumo a seguir, os números entre parênteses representam, respectivamente, valores exemplificativos para os ganhos para o devedor e credores. A expressão "Recuperação (pagamento significativo)" significa proposta de plano de recuperação na qual os administradores sinalizam aos credores pagar grande parte do valor dos créditos devidos. A expressão "Recuperação (pagamento insuficiente)" significa pagamento de pequena parcela do valor dos créditos. Para facilitar o entendimento, o modelo sumariza os ganhos para as três classes de credores $\left(\mathbf{R}_{\mathbf{C}}\right)$.

A legenda do quadro de soluções utiliza três cores para discriminar as alternativas: (i) verde: indica a melhor alternativa prevista pelo modelo; (ii) amarelo: representa uma alternativa não-ideal, mas possível de ocorrer; (iii) vermelho: aponta a pior escolha possível, a que traz maiores prejuízos coletivos. 


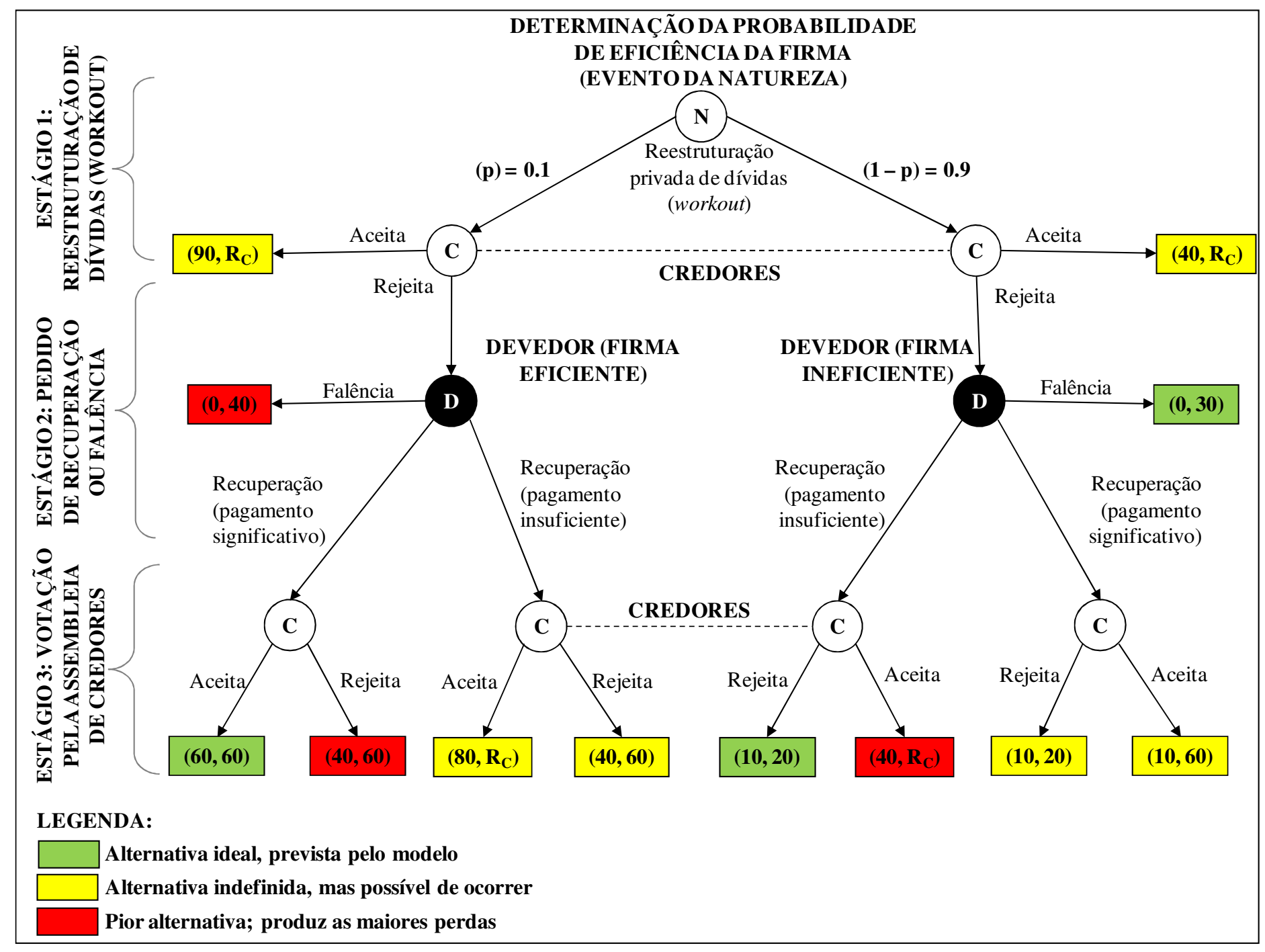




\section{Hipótese 1: quando os ganhos futuros são conhecidos.}

Quando os ganhos futuros são previsíveis e conhecidos, o retorno esperado é igual a $\left(R_{D}-D_{2}-F_{1}\right)$.

Se $\left(R_{D}-L\right)>0$, há recuperação no período 2 , isto é, os ganhos do período são maiores que o valor de liquidação $(\mathrm{L})$. Se $\left(\mathrm{R}_{\mathrm{D}}-\mathrm{L}\right)<0$, há liquidação no período 1 , porque os ganhos no período 2 são menores que L.

Para continuar em funcionamento, a empresa precisa obter empréstimo no período 1 para cobrir as despesas de operação do negócio no período $2, \operatorname{logo} F_{1} \geq D_{1}$.

Se $R_{D}<D_{2}$, não há retorno suficiente para pagar as despesas incorridas no período 2 e há perdas nas hipóteses de liquidação ou recuperação, o credor não emprestará o valor de $\mathrm{F}_{1}$ ao devedor e a decisão eficiente será a liquidação da empresa.

O devedor escolhe a recuperação se $\left(R_{D}-D_{2}-F_{1}\right)>0$, isto é, se $\left(R_{D}-D_{2}\right)>F_{1}$. Os ganhos do período 2, descontadas as despesas, devem superar o valor do empréstimo necessário para manter a empresa em operação.

Quando ambas as alternativas são deficitárias, porém na liquidação há menor perda, os credores devem receber $\left(\mathrm{R}_{\mathrm{D}}-\mathrm{L}\right)$ em caso de liquidação, mas o resultado é ignorado pelo devedor porque ele prefere a recuperação, deixando de tomar a decisão eficiente. Se ele escolher a falência, será o último a receber se houver saldo (art. 153), enquanto na recuperação compartilha riscos com os credores.

A decisão eficiente, do ponto de vista do interesse público, é aquela na qual o devedor escolhe a recuperação se o resultado for positivo: $R_{D}-D_{2}-F_{1}>0$. Se o devedor é altruísta, escolhe a recuperação se o ganho esperado for maior que o valor do empréstimo necessário para viabilizar a continuação do negócio no período 1, optando pela liquidação em caso contrário. Como o devedor não é altruísta, o pedido de autofalência (art. 105) é de improvável ocorrência, pois ele nada ganha. 


\section{Hipótese 2: quando os ganhos futuros não são conhecidos.}

Quando os ganhos futuros são imprevisíveis ou desconhecidos, o valor esperado é igual a $\left[\mathrm{r}\left(\mathrm{R}_{\mathrm{D}}+\mathrm{R}\right)+(1-\mathrm{r})\left(\mathrm{R}_{\mathrm{D}}-\mathrm{R}\right)\right]-\mathrm{D}_{2}-\mathrm{F}_{1}$.

Considere que "R" é a variação dos ganhos, e " $r$ " é a probabilidade de sucesso. Se a probabilidade de ganhar o valor de "R" for $(r)$ e a de perder " $R$ " for $(1-r)$ haverá recuperação se o ganho for positivo: $\left[r\left(R_{D}+R\right)+(1-r)\left(R_{D}-R\right)\right]-D_{2}>F_{1}$.

Há continuação se o ganho esperado com a recuperação é maior que o valor do empréstimo necessário para viabilizar a continuação no período 2 , isto é, se o resultado for positivo. Há liquidação se o ganho esperado for inferior ao valor do empréstimo.

O “bom resultado” é aquele no qual é possível pagar todas as dívidas e há sobras, caso contrário a empresa deve ser liquidada no período 2. O resultado é "bom" se $\left(R_{D}-R\right)>0$, isto é, $R_{D}>R$. O ganho total futuro deve ser maior que a expectativa inicial de ganho em caso de recuperação.

Com a introdução da incerteza ("R" e "r"), a recuperação pode ser escolhida mesmo que a liquidação seja mais eficiente, porque será difícil saber com antecedência o valor dos ganhos e a probabilidade de sucesso.

A recuperação é mais atrativa para o devedor quanto maior a variação dos ganhos ("R") e da probabilidade de sucesso ("r"), porque, em caso de "bom resultado", o devedor recebe o saldo excedente, depois que os credores tiverem sido pagos. Em caso de "mau resultado" o devedor perde apenas o valor do empréstimo $\left(\mathrm{F}_{1}\right)$ e os credores perdem o restante. O montante ("R") e a probabilidade de obtenção (" $r$ ") dos ganhos são variáveis com alto grau de incerteza.

Quanto maior o endividamento futuro (dívidas vencendo no período 2), mais atrativa será a recuperação para o devedor, porque o valor do empréstimo $\left(\mathrm{F}_{1}\right)$ para financiar a recuperação em $\mathrm{P}_{1}$ será menor, reduzindo a expectativa de perdas. 
Há dificuldades para obter o valor do empréstimo $\left(\mathrm{F}_{1}\right)$ porque não há incentivos para financiar o devedor.

\section{Escolhas estratégicas.}

\section{a) Reestruturacão privada de dívidas.}

A negociação direta é, geralmente, proposta pelo devedor, que reúne os credores com dívidas a vencer no curto prazo para propor alternativa de pagamento. A negociação também pode ser iniciada pelos credores, mas é hipótese improvável porque eles terão dificuldade em formar uma coletividade com interesses alinhados.

O jogo inicia com o evento da natureza que estima a eficiência da empresa. A probabilidade indicada não é casual. O valor de 0.1 para "p" e de 0.9 para $(1-p)$ sugere haver baixa probabilidade de encontrar empresa eficiente em recuperação ou falência. Não se pode afirmar que "p" seja zero, pois pode haver erro no processo de tomada de decisão que submete a concurso a empresa eficiente.

Depois ocorre a negociação, na qual os ganhos para o devedor são maiores, uma vez que se apropria de parte dos ganhos com a recuperação. Se a empresa é eficiente, o ganho é de 90, maior que 60 que receberia se oferecesse pagamento insuficiente. Se ineficiente, o ganho é 40, idêntico ao que receberia se oferecesse pagamento insuficiente, mas com a vantagem de "ganhar tempo" permanecendo à frente dos negócios. A economia de custos pode produzir incentivos para o devedor induzir os credores a erro na tentativa de se apropriar de ganhos adicionais.

O ramo esquerdo do jogo indica que os administradores de empresas eficientes não requerem a liquidação, pois é decisão irracional. As alternativas são: (i) reestruturação de dívidas; (ii) plano de recuperação com pagamento significativo; (iii) barganhar, oferecendo pagamento insuficiente no plano.

A empresa eficiente pode não desejar recorrer à recuperação e preferir resolver 
o problema por meio da reestruturação de dívidas. Nesse caso, o ganho é de 90, ao invés de 60, recebidos se opta pela recuperação. Para os credores, a melhor solução é aceitar a reestruturação de dívidas se o ganho $\left(\mathrm{R}_{\mathrm{C}}\right)$ for suficiente, isto é, maior ou igual a 60, pois recebem parte do valor rapidamente. A solução é encerrar o jogo no estágio 1 desde que a oferta seja suficiente para induzir a aceitação por todos os credores.

Há baixa probabilidade $(\mathrm{p}=0.1)$ de a empresa eficiente requerer recuperação ou falência; nessa espécie de empresa, em geral, há apenas desequilíbrio temporário de fluxo de caixa.

O ramo direito do jogo mostra a decisão dos administradores entre negociar a reestruturação privada de dívidas, requererem a autofalência (art. 105) ou desenharem plano de recuperação (art. 48). Para eles, é preferível a negociação direta, pois obtém o valor de 40, maior ganho possível. O problema é que a empresa é ineficiente e a negociação somente adia a crise.

\section{b) Falência.}

A falência pode ser requerida pelo devedor (autofalência, art. 105) ou pelos credores (art. 94).

O devedor da empresa eficiente não tem incentivos para escolher a autofalência pois será o último a receber, se houver saldo (art. 153), ao passo que, na recuperação, transfere parte do risco de continuação do negócio. Ele opta pela reestruturação privada de dívidas ou pela recuperação, uma vez que escolher a falência é decisão irracional.

No caso da empresa ineficiente, a solução ideal é levá-la à falência, hipótese que dificilmente ocorre por iniciativa do devedor, pois não há incentivos para tal.

Os credores podem requerer a falência do devedor. A falência da empresa eficiente traz aos credores um ganho de 40, menor que 60 que receberiam se preferissem a recuperação. Isto significa que a reestruturação de dívidas foi mal sucedida e o valor oferecido $\left(\mathrm{R}_{\mathrm{C}}\right)$ foi inferior a 40 . É hipótese inconsistente com o 
comportamento racional do devedor, pois leva um negócio próspero à falência.

Quando a empresa é ineficiente, os credores recebem 30 em caso de falência, ou 60 quando há recuperação com pagamento insuficiente. Significa que a reestruturação de dívidas foi mal sucedida e o valor de $\mathrm{R}_{\mathrm{C}}$ foi inferior ao obtido em caso de falência.

A decisão de não fazer nada e esperar a falência tem os mesmos efeitos da declaração de autofalência, com a diferença que, nesse caso, o devedor perde a iniciativa do jogo, deixando de ocupar posição estratégica.

O credor também pode ficar inerte e provisionar as perdas decorrentes do não recebimento dos créditos. O valor máximo de perda equivale ao valor de face dos créditos $\left(\mathrm{V}_{\mathrm{F} 1}+\mathrm{V}_{\mathrm{F} 2}+\mathrm{V}_{\mathrm{F} 3}\right)$.

\section{c) Recuperaç̃a.}

A recuperação é de iniciativa exclusiva do devedor.

Ele calcula o valor de "u", "s" e "t" para obter a aprovação do plano pelas classes de credores.

O valor dos créditos recebidos pelos credores com garantia menor e sem garantia é $\mathrm{R}(\mathrm{u})=\left(\mathrm{u} . \mathrm{V}_{\mathrm{F} 3}\right)$. $\mathrm{O}$ valor recebido pelos com garantia é $\mathrm{R}(\mathrm{s})=\left[\mathrm{s} \cdot \mathrm{V}_{\mathrm{F} 2}\right]$. Se este for pago com prioridade sobre aquele, então $(s>\mathrm{u})$. Os trabalhistas recebem $\mathrm{o}$ valor de $\mathrm{R}(\mathrm{t})=\left[\mathrm{t} . \mathrm{V}_{\mathrm{F} 1}\right]$.

O valor da dívida negociada é: $D_{P}=\left[(1-t) V_{F 1}+(1-s) V_{F 2}+(1-u) V_{F 3}\right]$.

Quando os ganhos futuros são conhecidos, o retorno eficiente com a recuperação é $\left(R_{D}-L\right)$, diferença entre os ganhos futuros e o valor de liquidação. $O$ valor dos custos de transação é $\mathrm{C}$.

A escolha eficiente é a recuperação se $\left(R_{D}-L\right)>C$, isto é, quando o ganho 
adicional, comparado ao valor de liquidação, supera os custos. O devedor prefere a recuperação se a receita, deduzidas as dívidas negociadas no plano, superar os custos $\left(\mathrm{D}_{\mathrm{P}}>\mathrm{C}\right)$.

Assim: $\mathrm{R}_{\mathrm{D}}-\left[\left(\mathrm{t}, \mathrm{V}_{\mathrm{F} 1}\right)+\left(\mathrm{s}, \mathrm{V}_{\mathrm{F} 2}\right)+\left(\mathrm{u} . \mathrm{V}_{\mathrm{F} 3}\right)\right]>\mathrm{C}, \mathrm{e} \mathrm{D}_{\mathrm{NP}}=\left[\left(\mathrm{t}, \mathrm{V}_{\mathrm{F} 1}\right)+\left(\mathrm{s} . \mathrm{V}_{\mathrm{F} 2}\right)+\right.$ $\left.\left(\mathrm{u} . \mathrm{V}_{\mathrm{F} 3}\right)\right]$. O devedor escolhe tal opção se o valor da liquidação for menor que o valor das dívidas a pagar $\left(\mathrm{L}<\mathrm{D}_{\mathrm{NP}}\right)$, mas a decisão eficiente seria a liquidação, quando o saldo é maior que o valor das dívidas. Há incentivos para escolher a recuperação, pois os ganhos para os credores $\left(R_{D}-L\right)$ são ignorados pelo devedor. A liquidação é prejudicial ao devedor, uma vez que ele é o último a receber, se houver saldo.

O incentivo para a escolha eficiente ocorre se o valor das dívidas a pagar pelo plano é maior ou igual ao valor de liquidação $\left(\mathrm{D}_{\mathrm{NP}} \geq \mathrm{L}\right)$, isto é: $\left[\left(\mathrm{t} . \mathrm{V}_{\mathrm{F} 1}\right)+\left(\mathrm{s} . \mathrm{V}_{\mathrm{F} 2}\right)+\right.$ $\left.\left(\mathrm{u} . \mathrm{V}_{\mathrm{F} 3}\right)\right] \geq \mathrm{L}$. O percentual médio de ganho para os credores na recuperação deve ser pelo menos igual ao valor de liquidação, dividido pelo valor de face dos créditos, não inferior a: $\left[\left(\mathrm{t} . \mathrm{V}_{\mathrm{F} 1}\right)+\left(\mathrm{s} . \mathrm{V}_{\mathrm{F} 2}\right)+\left(\mathrm{u} . \mathrm{V}_{\mathrm{F} 3}\right)\right] /\left(\mathrm{V}_{\mathrm{F} 1}+\mathrm{V}_{\mathrm{F} 2}+\mathrm{V}_{\mathrm{F} 3}\right)$.

Quando os ganhos futuros não são conhecidos, o retorno eficiente com a recuperação é $\left[r\left(R_{D}+R\right)+(1-r)\left(R_{D}-R\right)\right]-L$, e o custo eficiente é C. Nesse caso, a recuperação é ainda mais interessante para o devedor, permitindo forçar os credores a investir na atividade de risco.

Se os ganhos são $\left(R_{D}+R\right)$ com probabilidade $(r)$ e $\left(R_{D}-R\right)$ com probabilidade $(1-\mathrm{r})$, o devedor escolhe a recuperação quando o valor esperado em caso de "bom resultado" é positivo. A decisão eficiente ocorre se $\left[\mathrm{r}\left(\mathrm{R}_{\mathrm{D}}+\mathrm{R}\right)+(1-\mathrm{r})\left(\mathrm{R}_{\mathrm{D}}-\mathrm{R}\right)\right]-\mathrm{L}$ $>$ C. O devedor opta pela recuperação se as dívidas negociadas excedem os custos incorridos $\left(\mathrm{D}_{\mathrm{P}}>\mathrm{C}\right)$.

Outra vez, o devedor baseia a escolha somente nos ganhos em caso de "bom resultado”, quando a decisão eficiente deveria também levar em conta os casos desfavoráveis. Como a decisão de requerer a recuperação judicial é exclusiva do devedor, ele desconsidera a hipótese de "mau resultado", apresenta o plano e deixa a decisão de aprová-lo ou rejeitá-lo para os credores (estágio 3 do jogo). 
A atratividade da recuperação aumenta quando "R" e " $r$ " aumentam e o valor das dívidas perdoadas é alto, isto é, se a soma do valor reembolsado aos credores trabalhistas $\left(\mathrm{t} . \mathrm{V}_{\mathrm{F} 1}\right)$, com garantia $\left(\mathrm{s}, \mathrm{V}_{\mathrm{F} 2}\right)$ e sem garantia $\left(\mathrm{u} . \mathrm{V}_{\mathrm{F} 3}\right)$ for o menor possível.

O devedor da empresa eficiente sempre deve optar por plano que preveja pagamento significativo. Ele prefere não se arriscar e obter ganho de 60 , ao invés de barganhar e receber 80 , se o plano é aprovado, ou 40 se rejeitado. Para os credores, $\mathrm{R}_{\mathrm{C}}$ deve ser sempre maior que 60 para justificar a aprovação.

O devedor da empresa ineficiente sempre deve preparar plano que prevê pagamento insuficiente. Se ele optar por pagamento significativo, ganha apenas 10, mas, se barganhar, pode ganhar 40 se os credores aprovam o plano, ou 10 se o rejeitam. Estes ganham 60 se o plano prevê pagamento significativo, mas, em caso de pagamento insuficiente, ganham 20 se o plano é rejeitado pelos credores, ou o valor de $R_{C}$, se o plano é aprovado. Nesse caso, rejeitar a oferta será a estratégia dominante para os credores porque $\mathrm{R}_{\mathrm{C}}$ será sempre menor que 60 . Como o credor tem menos informação que o devedor sobre a crise, pode decidir não se arriscar e evitar perdas por meio da rejeição do plano, obrigando o juiz a decretar a falência (art. 56, §4º ), caso em que receberá 30 .

Os credores, por sua vez, devem decidir em assembléia o destino da empresa em crise, votando o plano de recuperação sem saber se a empresa é eficiente.

O devedor da empresa eficiente recebe 60 se oferece pagamento significativo, mas se tenta barganhar com oferta insuficiente, recebe 40 em caso de rejeição, ou 80 se há aceitação. Os credores recebem 60 quando há pagamento significativo e, no caso de pagamento insuficiente, recebem 60 se a rejeitam, ou o valor de $\mathrm{R}_{\mathrm{C}}$ se a aceitam.

O devedor da empresa ineficiente recebe 10 se oferece pagamento significativo, mas se tenta oferecer pagamento insuficiente, recebe 10 se os credores rejeitam a oferta, ou 40 se a aceitam. Os credores recebem 60 quando há pagamento significativo. Se há 
pagamento insuficiente, recebem 20 se a rejeitam, ou o valor de $\mathrm{R}_{\mathrm{C}}$ se a aceitam.

O valor esperado é $\mathrm{R}_{\mathrm{C}}=(\mathrm{p}) .60+(1-\mathrm{p}) .20=24$. Os credores sempre devem aceitar a oferta se $R_{C}$ for maior que 24 . Como $R_{C}$ não é significativamente maior que 20 (ganho em caso de falência), os credores podem preferir não se arriscar por pequeno ganho adicional e rejeitar o plano, requerendo a falência (art. 56, §4 $4^{\circ} \mathrm{c} / \mathrm{c}$ art. 73 , III).

Se os credores aceitam pagamento insuficiente, sempre é do interesse do devedor oferecê-lo para se apropriar da diferença. Se a empresa é eficiente, o ganho é de 80 , maior que 60, recebido em caso de pagamento significativo. Se a empresa é ineficiente, o ganho, em caso de pagamento insuficiente, é de 40, se os credores aceitam a oferta, maior que 20, obtido em caso de autofalência ou pagamento significativo na recuperação. É situação na qual os jogadores foram induzidos a erro porque o devedor sempre se beneficia quando os credores não conseguem saber se a empresa é eficiente. Há erro porque os credores aceitam valor inferior ao que a empresa poderia oferecer, e também porque o devedor consegue adiar a falência quando os credores não percebem com qual espécie de empresa estão lidando.

Se as probabilidades $(\mathrm{p})$ e $(1-\mathrm{p})$ forem alteradas para, respectivamente, 0.9 e 0.1 , o retorno $\left(\mathrm{R}_{\mathrm{C}}\right)$ para os credores que aceitam a oferta insuficiente se modifica. Se eles rejeitam a oferta, o retorno é $R_{C}=(p) .60+(1-p) .20=56$. Nesse caso, os credores sempre rejeitam o plano se $\mathrm{R}_{\mathrm{C}}$ for menor que 56. Essa situação sempre ocorre porque os credores recebem 60 , em caso oferta de pagamento significativo, valor superior a $\mathrm{R}_{\mathrm{C}}$. $\mathrm{O}$ devedor sempre oferece o valor mais baixo possível, resultado que é incoerente quando $\mathrm{R}_{\mathrm{C}}$ toma o valor de 56 .

O devedor racional da empresa eficiente não oferece pagamento insuficiente porque o ganho de 60, para pagamento significativo, é maior que 40, obtido quando os credores rejeitam a oferta. Também o devedor da empresa ineficiente não oferece pagamento significativo porque o ganho para ele, se os credores rejeitam a oferta, é de 10, o menor possível. É situação na qual não ocorre erro e o procedimento concursal funciona com os incentivos corretos, desde que os credores saibam diferenciar a espécie de empresa (eficiente ou ineficiente) com a qual estão negociando. 
Há solução correta quando empresas eficientes oferecem pagamentos significativos e quando as ineficientes são levadas à falência. As demais alternativas levam a resultados incorretos porque há erro no processo de decisão.

Se o plano é rejeitado, os credores com garantia real (classe II) podem executar as garantias pelo valor de liquidação (L) ou de mercado, solicitando ao devedor retorno igual ao valor da garantia, dividido pelo valor de face dos créditos. $\mathrm{O}$ retorno $\left(\mathrm{s} . \mathrm{V}_{\mathrm{F} 2}\right)$ deverá ser maior ou igual ao valor de venda dos bens dados em garantia.

Os credores sem garantia e com garantia menor (classe III) também podem sinalizar que irão tentar impedir a aprovação, na tentativa de negociar a taxa de retorno (u). O retorno $\left(\mathrm{u} . \mathrm{V}_{\mathrm{F} 3}\right)$ para compensar a aprovação deverá ser pelo menos igual ao valor de liquidação (L), que tende a ser baixo para essa classe.

Os credores trabalhistas (classe I) tendem a obter taxa de retorno (t) maior porque há alto grau de proteção legal a esses créditos. $\mathrm{O}$ retorno $\left(\mathrm{t}, \mathrm{V}_{\mathrm{F} 1}\right)$ deve ser pelo menos igual ao valor de liquidação (L). 


\section{Bibliografia.}

ABRÃO, Nelson. A continuação do negócio na falência. 2a ed., São Paulo: LEUD, 1998.

O novo direito falimentar: nova disciplina jurídica da crise econômica da empresa. São Paulo: RT, 1985.

O síndico na administração concursal. São Paulo: Revista dos Tribunais, 1998.

ADLER, Barry E. (coord.) Foundations of bankruptcy law. New York: Foundation Press, 2005.

. Game-theoretic bankruptcy valuation. New York University - Law and Economics Research Paper Series n. 07-03, January 2007. Disponível em: $<$ http://www.ssrn.com>. Acesso em: 29.jan.2007.

AKKERMANS, Henk. Modeling with managers - participative business modeling for effective strategic decision-making. Goirle (The Netherlands): BSO, 1995.

AKERLOF, George. The market for lemons: quality uncertainty and the market mechanism. Quarterly Journal of Economics, Vol. 84, n. 3, pp. 488-500, August 1970.

ALTMAN, Edward I. Corporate financial distress and bankruptcy: a complete guide to predicting and avoiding distress and profiting from bankruptcy. $2^{\text {nd }}$ ed., New York: John Wiley, 1993.

ARAÚJO, Aloísio Pessoa de; FUNCHAL, Bruno. Bankruptcy law in Latin America: past and future. Economia, n. 599, pp. 149-216, Agosto 2005. Disponível em <http://epge.fgv.br/portal/pt/pesquisa/producao/1922.html>. Acesso em: 05.set.2007

Recuperação de empresas: uma múltipla visão da nova lei - Lei 11101/05 de 09.02.2005. In Reflexões a partir da Lei $\mathrm{n}^{\circ}$ 11.101/05 - O impacto econômico da nova Lei de Falência e Recuperação de Empresas. Vol. 1, pp. 32-42, 2006. Disponível em 
<http://epge.fgv.br/we/brunofunchal>. Acesso em: 05.set.2007.

ASCARELLI, Tullio, Corso di diritto commerciale - introduzione e teoria dell' impresa. $3^{\mathrm{a}}$ ed., Milano: Giuffrè, 1962.

ASQUINI, Alberto. Os perfis da empresa. Tradução: Fabio K. Comparato. Revista de Direito Mercantil, Industrial, Econômico e Financeiro, Ano XXXV, n. 104, pp. 109-126, Out./Dez. 1996.

AUMANN, Robert J.; MASCHLER, Michael. Game theoretic analysis of a bankruptcy problem from the Talmud. Journal of Economic Theory, n. 36, pp. 195-213, 1985.

AXELROD, Robert. The complexity of cooperation. Princeton: Princeton University Press, 1997.

BAIRD, Douglas G. Chapter 11 at twilight. John M. Olin Law and Economics Working Paper Series - University of Chicago Law School, Working paper n. 201, 2003. Disponível em: <http://papers.ssrn.com/abstract=455960>. Acesso em: 20.fev.2006.

BAIRD, Douglas G.; JACKSON, Thomas H. Corporate reorganizations and the treatment of diverse ownership interests: a comment on adequate protection of secured creditors in bankruptcy. University of Chicago Law Review, n. 51, pp. 97-130, 1984.

BAIRD, Douglas G.; RASMUSSEN, Robert K. The end of bankruptcy. Stanford Law Review, v. 55, pp. 751-790, 2002/2003.

BANCO MUNDIAL. Principles and guidelines for effective insolvency and creditor rights systems. World Bank Legal Review - Law and Justice for Development, 2001. Disponível em: <http://www.worldbank.org/gild>. Acesso em: 10.out.2005.

BAROSSI FILHO, Milton. As assembléias de credores e plano de recuperação de empresas: uma visão da teoria dos jogos. Revista de Direito Mercantil, Industrial, Econômico e Financeiro, Ano XLIV, n. 137, pp. 233-238, Jan./Mar. 2005. 
BARZEL, Yoram. Economic analysis of property rights. $2^{\text {nd }}$ ed., New York: Cambridge University Press, 2003.

BATISTA, Carolina Soares João; CAMPANA FILHO, Paulo Fernando; MIYAZAKI, Renata Yumi; CEREZETTI, Sheila Cristina Neder. A prevalência da vontade da assembléia-geral de credores em questão: o cram down e a apreciação judicial do plano aprovado por todas as classes. Revista de Direito Mercantil, Industrial, Econômico e Financeiro, Ano XLV, n. 143, pp. 202-236, Jul./Set. 2006.

BERKOWITZ, Jeremy; WHITE, Michelle J. Bankruptcy and small firms' access to credit. John M. Olin Center for Law \& Economics - University of Michigan Law School, Paper n. 00-005, June 2000. Disponível em: <http://papers.ssrn.com/paper.taf?abstract_id= 233248>. Acesso em: 23.jan.2006.

BEZERRA FILHO, Manoel Justino. Nova lei de recuperação e falências comentada. $3^{\text {a }}$ ed., São Paulo: RT, 2005.

Jurisprudência da nova lei de recuperação e falências comentada. São Paulo: RT, 2006.

BOBBIO, Norberto. Da estrutura à função: novos estudos de teoria do direito. São Paulo: Manole, 2007.

BOITEUX, Fernando Netto. Contratos mercantis. São Paulo: Dialética, 2002.

CABRILLO, Francisco; DEPOORTER, Ben W. F. Bankruptcy proceedings. Encyclopedia of Law and Economics. Disponível em: <http://encyclo.findlaw.com/7800.html>. Acesso em: 11.nov.2005.

CALABRESI, Guido. Remarks: The simple virtues of The Cathedral. Yale Law Journal, n. 106, pp. 2201-2207, 1996-1997. 
The pointlessness of Pareto: carrying Coase further. Yale Law Journal, n. 100, pp. 1211-1238, 1991.

CALABRESI, Guido; MELAMED, Douglas A. Property rules, liability rules, and inalienability: one view of the cathedral. Harvard Law Review, Vol. 85, n. 6, pp. 10891128, April 1972.

CAMERER, Colin F.; HO, Teck-Hua; CHONG, Juin-Kuan. A cognitive hierarchy theory of one-shot games and experimental analysis. September 8, 2003. Disponível em $<$ http://www.ssrn.com>. Acesso em: 03.dez.2006.

CAOUETTE, John B.; ALTMAN, Edward I. ; NARAYANAN, Paul. Gestão do risco de crédito. Rio de Janeiro: Qualitimark, 2000.

CARVAlHOSA, Modesto; LATORRACA, Nilton. Comentários à lei de sociedades anônimas. São Paulo: Saraiva, 1997, Vol. 2, 3.

CHIAPPIN, J. R. N.; LEISTER, Ana C. Experimento mental I: a concepção contratualista clássica, o modelo da tragédia dos comuns e as condições de emergência e estabilidade da cooperação - Hobbes. Maio 2007. Disponível em: <http://repositories.cdlib.org/bple/alacde/052307-1>. Acesso em: 01.jun.2007.

Experimento mental II: a concepção contratualista clássica, o modelo da tragédia dos comuns e as condições de emergência e estabilidade da cooperação - Locke, Rousseau Kant. Maio $2007 . \quad$ Disponível em: <http://repositories.cdlib.org/bple/alacde/060507-1>. Acesso em: 01.jun.2007.

Reconstrução racional do programa de pesquisa da política, e do direito, como ciência e da abordagem do problema da emergência e estabilidade da cooperação entre indivíduos interagentes. A construção do Estado de Direito e o núcleo teórico do contratualismo. Não publicado, 2007. 
ciência e da abordagem do problema da emergência e estabilidade da cooperação entre indivíduos interagentes. A construção do Estado de Direito e a heurística do contratualismo. Não publicado, 2007.

CLAESSENS, Stijn; KLAPPER, Leora F. Bankruptcy around the world - explanations of its relative use. Policy Research Working Paper n. 2865, July 2004. Disponível em: $<$ http://www.worldbank.org >. Acesso em: 25.abr.2006.

CLAESSENS, Stijn; DJANKOW, Simeon; KLAPPER, Leora F. Resolution of corporate distress - evidence from East Asia's financial crisis. Policy Research Working Paper n. 2133, June 1999. Disponível em: <http://www.worldbank.org>. Acesso em: 25.abr.2006.

CLARK, Robert Charles. Corporate law. New York: Aspen Law and Business, 1986.

COASE, Ronald H. The firm, the market, and the law. Chicago: University of Chicago Press, 1990.

COELHO, Fabio Ulhoa. Comentários à nova lei de falências e de recuperação de empresas. São Paulo: Saraiva, 2005.

COMPARATO, Fabio Konder. Aspectos jurídicos da macro-empresa. São Paulo: Revista dos Tribunais, 1970.

Ensaios e pareceres de direito empresarial. Rio de Janeiro: Forense, 1978.

Estado, empresa e função social. Revista dos Tribunais, Ano 85, v. 732, pp. 3846, Out. 1996.

Função social da propriedade dos bens de produção. Revista de Direito Mercantil, Industrial, Econômico e Financeiro, Ano XXV, n. 63, pp. 71-79, Jul./Set. 1986.

COOTER, Robert; ULEN, Thomas. Law and economics. $4^{\text {th }}$ ed., Addison-Wesley Series in Economics, 2003. 
DAVIS, Morton D. Teoria dos jogos - uma introdução não técnica. Tradução: Leonidas Hezenberg. São Paulo: Cultrix, 1973.

DEMSETZ, Harold. Toward a theory of property rights. The American Economic Review, V. 57, n. 2, Papers and Proceedings of the Seventy-ninth Annual Meeting of the American Economic Association, pp. 347-359, May 1967. Disponível em <http://www.ssrn.com>. Acesso em: 03.out.2006.

DE LUCCA, Newton; SIMÃO FILHO, Adalberto (coord.). Comentários à nova lei de recuperação de empresas e de falências: comentários artigo por artigo da Lei $n^{\circ}$ 11.101/2005. São Paulo: Quartier Latin, 2005.

ENRIQUES, Luca. Il conflitto d'interessi nella gestioni delle società per azioni: spunti teorici e profili comparatistici in vista della riforma del diritto societario. Rivista delle Società, Ano 45\% / 2000, pp. 509-561, Mai./Ago. 2000, fascículo 3-4º .

ENRIQUES, Luca; GELTER, Martin. How the old world encountered the new one: regulatory competition and cooperation in European corporate and bankruptcy law. European Corporate Governance Institute (ECGI) Working Paper Series in Law, No. 63/2006, February 2006. Disponível em <http://ssrn.com/abstract=887164>. Acesso em: 06.ago.2007.

FIANI, Ronaldo. Teoria dos jogos. $2^{\mathrm{a}}$ ed., São Paulo: Campus, 2006.

FONSECA, Priscila Corrêa da. Suspensão de deliberações sociais. São Paulo: Saraiva, 1986.

FRANÇA, Erasmo Valladão de A. e N. Assembléia-geral de credores. Revista do Advogado, ano XXV, n. 83, pp. 42-50, Set. 2005.

Conflito de interesses nas assembléias de S. A. São Paulo: Malheiros Editores, 1993. 
. Empresa, empresário e estabelecimento. A nova disciplina das sociedades. Revista do Advogado, ano XXIII, n. 71, pp. 15-25, Ago. 2003.

FURTADO, Cláudio Vilar. Emissão de ações e valor de mercado da empresa: um estudo de ofertas primárias de ações negociadas em bolsas de valores no Brasil. Tese de Doutorado. São Paulo: EAESP/FGV, 1997.

GARDINO, Adriana V. Pugliesi. A evolução do tratamento jurídico da empresa em crise no direito brasileiro. Dissertação de Mestrado. São Paulo: Faculdade de Direito da Universidade de São Paulo, 2006.

GIBBONS, Robert. Game theory for applied economists. Princeton: Princeton University Press, 1992.

GIGERENZER, Gerd; ENGEL, Christoph (coord.). Heuristics and the law. Cambridge: The MIT Press, 2004.

GINTIS, Herbert. Game theory evolving - A problem-centered introduction to modeling strategic interaction. Princeton: Princeton University Press, 2000.

GRAU, Eros Roberto. A ordem econômica na Constituição de 1988. 5a ed., São Paulo: Malheiros, 2000.

GULATI, G. Mitu; KLEIN, William A.; ZOLTI, Eric M. Connected contracts. University of California Law Review, v. 47, pp. 887-948, 2000. Disponível em $<$ http://ssrn.com/abstract=217590>. Acesso em: 19.nov.2006.

HEAP, Shaun P. Hargreaves; VAROUFAKIS, Yanis. Game theory, a critical introduction. London: Routledge, 1997.

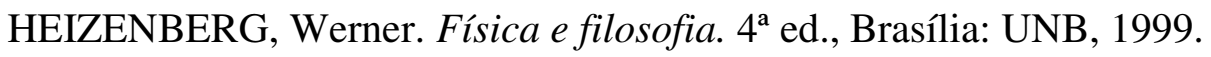


HOEL, Paul G. Estatística elementar. São Paulo: Atlas, 1977.

HURWICZ, Leonid. But who will guard the guardians? May 1998. Disponível em <http://www.econ.umn.edu/hurwicz>. Acesso em: 15.jan.2008.

IUDÍCIBUS, Sérgio (coord.). Contabilidade introdutória - equipe de professores da FEA/USP. 9a ed., São Paulo: Atlas, 1998.

JENSEN, Michael C.; MECKLING, William H. Theory of the firm: managerial behaviour, agency cost and ownership structure. Journal of Financial Economics, v. 3, n. 4, 1976. Disponível em <http://papers.ssrn.com/sol3/paper.taf?abstract_id=94043>. Acesso em: 15.mai.2006.

KANITZ, Stephen C. Como prever falências. São Paulo: McGraw-Hill, 1978.

KASMIER, Leonard J. Estatística aplicada à economia e administração. São Paulo: Makron Books, 1982.

LABOVITZ, M. Natasha; BASIL, Jessica I. It's a small world after all: a survey of recent developments in US Bankruptcy Law and their potential multinational impact. Business Law International, v. 7, n. 1, pp. 39-52, January 2006.

LEITE, Helio de Paula. Contabilidade para administradores. $3^{\text {a }}$ ed., São Paulo: Atlas, 1995.

LOBO, Jorge Joaquim. Da recuperação da empresa no direito comparado. Rio de Janeiro: Lumen Juris, 1993. . Direito da crise econômica da empresa. São Paulo: Revista dos Tribunais, v. 87, n. 754 , pp. 11-44. Pressupostos da quebra. Revista de Direito Mercantil, Industrial, Econômico e Financeiro. V.39, n.116, pp.110-117, Out./Dez. 1999.

LOPUCKI, Lynn M. The nature of the bankrupt firm: a reply to Baird and Rasmussen's 
'The End of Bankruptcy'. Stanford Law Review, v. 56, pp. 645-672, 2003/2004.

MARTINS, Eliseu. Contabilidade introdutória. 9ª ed., São Paulo: Atlas, 1998.

MYERSON, Roger B. Fundamental theory of institutions: a lecture in honor of Leo Hurwicz. North American Meetings of the Econometric Society (22.06.2006). Disponível em <http://home.uchicago.edu/ rmyerson/hurwicz.pdf>. Acesso em: 15.jan.2008.

. Game theory - analysis of conflict. Cambridge: Harvard University Press, 1991.

MANTZAVINOS, C.; NORTH, Douglass C.; SHARIQ, Syed. Learning, institutions and economic performance. Preprints of the Max Planck Institute for Research on Collective Goods, Bonn, 2003/13. Disponível em <http://ssrn.com/abstract=510902>. Acesso em: 23.jan.2006.

MASKIN, Eric S.; SJÖSTRÖM, Tomas. Implementation theory. September 17, 2001. Disponível em <http://www.sss.ias.edu/publications/economicsworking.php>. Acesso em: 15.jan.2008.

MERCURO, Nicholas; MEDEMA, Steven G. Economics and the law. Princeton: Princeton University Press, 1997.

MORRIS, Peter. Introduction to game theory. New York: Springer-Verlag, 1994.

NORTH, Douglass C. Institutions, institutional change and economic performance. New York: Cambridge University Press, 2002.

PAIVA, Luiz Fernando Valente de. Apresentação do plano de recuperação pelo devedor e atuação dos credores. Revista do Advogado, ano XXV, n. 83, pp. 73-81, Set. 2005.

(coord.). Direito falimentar e a nova lei de falências e recuperação de empresas. São Paulo: Quartier Latin, 2005. 
PARISI, Francesco. Positive, normative and functional schools in law and economics. European Journal of Law and Economics, V. 18, N. 3, December 2004, in http://ssrn.com/abstract_id=586641. Acesso em: 05.nov.2006.

PARISI, Francesco; SMITH, Vernon. The law and economics of irrational behavior: an introduction. George Mason University Law and Economics Research Paper Series. Disponível em: <http://ssrn.com/abstract_id=586649>. Acesso em: 15.abr.2006.

PAVAN, Alessandro; CALZOLARI, Giacomo. Truthful revelation mechanisms for simultaneous common agency games. July 2007. Disponível em: $<$ http://ssrn.com/abstract=1017745>. Acesso em: 10.jun.2008.

PINDYCK, Robert S.; RUBINFELD, Daniel L. Microeconomia. São Paulo: Makron Books, 1994.

PINTO, Anibal; FREDES, Carlos; MARINHO, Luiz Claudio. Curso de Economia. 9a ed., São Paulo: Unilivros, 1983.

REQUIÃO, Rubens. Curso de direito falimentar. $17^{\mathrm{a}}$ ed., atualizada por Rubens Edmundo Requião, São Paulo: Saraiva, 1998.

A crise do direito falimentar brasileiro. Revista de Direito Mercantil, Industrial, Econômico e Financeiro, n. 14, pp. 23-33, 1974.

ROE, Mark J. Corporate reorganization and bankruptcy - legal and financial materials. University Casebook Series, New York: Foundation Press, 2000.

ROSSI, Riccardo. Insolvenza, crisi di impreza e risanamento. Milano: Giuffrè, 2003.

SAAD, Eduardo Gabriel; SAAD, José Eduardo Duarte; BRANCO, Ana Maria Saad Castello. CLT comentada. $38^{\mathrm{a}}$ ed., São Paulo: LTR, 2005.

SADDI, Jairo (coord.). Intervenção e liquidação extrajudicial no sistema financeiro 
nacional - 25 anos da Lei 6.024/74. São Paulo: TextoNovo, 1999.

SALOMÃO FILHO, Calixto. O novo direito societário. $2^{\text {a }}$ ed., São Paulo: Malheiros, 2002. Regulação da atividade econômica (princípios e fundamentos jurídicos). São Paulo: Malheiros, 2001.

SAMPAIO DE LACERDA, José Cândido. Manual de direito falimentar. $14^{\mathrm{a}}$ ed., Rio de Janeiro: Freitas Bastos Editora, 1999.

SANDRONI, Paulo. Dicionário de Economia. $3^{\text {a }}$ ed., São Paulo: Best Seller, 1994.

SCHRICKEL, Wolfgang Kurt. Análise de crédito - concessão e gerência de empréstimos. $4^{a}$ ed., São Paulo: Atlas, 1998.

SOUZA JR, Francisco Satiro de; PITOMBO, Antonio Sérgio A de Moraes (coord.). Comentários à lei de recuperação de empresas e falência. $1^{\mathrm{a}}$ ed., São Paulo: Revista dos Tribunais, 2005.

Comentários à lei de recuperação de empresas e falência. $2^{\mathrm{a}}$ ed., São Paulo: Revista dos Tribunais, 2007.

SECURATO, José Roberto. Cálculo financeiro das tesourarias. $2^{\mathrm{a}}$ ed., São Paulo: Saint Paul Institute of Finance Editora, 2003.

STANGHELLINI, Lorenzo. Crisi di impresa fra diritto ed economia - le procedure di insolvenza. Bologna: Il Mulino, 2007.

Proprietà i controllo dell'impresa in crisi. Rivista delle Società, Ano 49 / 2004, pp. 1041-1081, Set./Out. 2004, fascículo 5

STIGLER, George J. Law or economics? Journal of Law \& Economics, vol. XXXV, pp. 455-467, October 1992. 
SZTAJN, Rachel. Função social do contrato e direito de empresa. Revista de Direito Mercantil, Industrial, Econômico e Financeiro, Ano XLIV, n. 139, pp. 29-47, Jul./Set. 2005.

Law and economics. Revista de Direito Mercantil, Industrial, Econômico e Financeiro, Ano XLIV, n. 137, pp. 227-232, Jan./Mar. 2005.

. Notas sobre as assembléias de credores na Lei de Recuperação de Empresas. Revista de Direito Mercantil, Industrial, Econômico e Financeiro, Ano XLIV, n. 138, pp. 53-70, Abr./Jun. 2005.

SZTAJN, Rachel; VERÇOSA, Haroldo M. D. A incompletude do contrato de sociedade. Revista de Direito Mercantil, Industrial, Econômico e Financeiro, Ano XLII, n. 131, pp. 720, Jul./Set. 2003.

THE ROYAL SWEDISH ACADEMY OF SCIENCES. The prize in economic sciences information to the public. 2007. Disponível em <http://www.nobelprize.org>. Acesso em: 01.nov.2007.

THE ROYAL SWEDISH ACADEMY OF SCIENCES. The prize in economic sciences scientific background. 2007. Disponível em <http://www.nobelprize.org>. Acesso em: 01.nov.2007.

TOLEDO, Paulo Fernando Campos Salles de. A empresa em crise no direito francês $e$ americano. Dissertação de Mestrado. São Paulo: Faculdade de Direito da Universidade de São Paulo, 1987.

. Recuperação judicial, a principal inovação da Lei de Recuperação de Empresas - LRE. Revista do Advogado, ano XXV, n. 83, pp. 98-106, Set. 2005.

Liquidação extrajudicial de instituições financeiras: alguns aspectos polêmicos. Revista de Direito Mercantil, Industrial, Econômico e Financeiro, n. 60, pp. 24-38, 
Out./Dez. 1985.

TOLEDO, Paulo Fernando Campos Salles de; ABRÃO, Carlos Henrique (coord.). Comentários à lei de recuperação de empresas e falência. São Paulo: Saraiva, 2005.

TRUJILLO, Bernard. Patterns in a complex system: an empirical study of valuation in business bankruptcy cases. UCLA Law Review, n. 53, pp. 356-404, 2005. Disponível em: www.ssrn.com. Acesso em 29.jan.2007.

TVERSKY, Amos; KAHNEMANN, Daniel. Prospect theory: an analysis of decision under risk. Econometrica, Vol. 47, n. 2, pp. 263-292, Mar. 1979.

Rational choice and the framing of decisions. Journal of Business, Vol. 59, n. 4, Part 2: The Behavioral Foundations of Economic Theory, pp. S251-278, October 1986.

VALVERDE, Trajano de Miranda. Comentários à lei de falências - Decreto-Lei n. 7.661, de 21.6.45. Atualizado por J. A. Penalva Santos e Paulo Penalva Santos, Rio de Janeiro, Forense, Volume I, 1999.

VERÇOSA, Haroldo Malheiros Duclerc. Curso de direito comercial. São Paulo: Malheiros, vol. 1, 2004.

. Curso de direito comercial. São Paulo: Malheiros, vol. 2, 2006.

. O status jurídico do controlador e dos administradores na recuperação judicial. Revista de Direito Mercantil, Industrial, Econômico e Financeiro, n. 143, pp.21-38, Jul.Set. 2006.

WEBB, David C. An economic evaluation of insolvency procedures in the United Kingdom: does the 1986 Insolvency Act satisfy the creditors' bargain? Oxford Economic Papers, New Series, Vol. 43, N. 1, pp. 139-157, Jan. 1991.

The importance of incomplete information in explaining the existence of costly 
bankruptcy. Economica, New Series, Vol. 54, n. 215, pp. 279-288, Aug. 1987.

WHITE, Michele J. Corporate bankruptcy as a filtering device: Chapter 11 reorganizations and out-of-court debt restructurings. Journal of Law, Economics and Organization, n. 10, pp. 268-295, 1984.

Corporate bankruptcy. Disponível em <http://www.ssrn.com>. Acesso em: 16.abr.2006.

Public policy towards bankruptcy: me-first and other priority rules. Bell Journal of Economics, n.11, pp. 550-564, 1980.

The corporate bankruptcy decision. In: POSNER, Richard; PARISI, Francesco, Law and Economics, Cheltenham, UK: Lyme, US: Edward Elgar Publishing, Volume III, pp. 293-371, 1997.

WIEDEMANN, Herbert. Excerto do Direito Societário I - Fundamentos. Tradução: Erasmo Valladão de A. e N. França. Revista de Direito Mercantil, Industrial, Econômico e Financeiro, n. 143, pp. 66-75, Jul.-Set. 2006.

Gesellschaftsrecht I (Grundlagen). Munique: Beck, 1980.

WILLIAMSON, Oliver E. The economic institutions of capitalism. New York: Free Press, 1987.

ZYLBERSTAJN, Decio; SZTAJN, Rachel. (coord.) Direito e economia - análise econômica do direito e das organizações. São Paulo: Campus, 2005. 


\section{Resumo.}

Esta dissertação de mestrado utiliza metodologia de direito e economia para apresentar modelo teórico construído a partir do ferramental disponibilizado pela teoria dos jogos. O modelo é desenhado com o objetivo de analisar as estratégias para tomada de decisão de devedores e credores sobre o pedido de falência e recuperação da empresa em crise no Brasil. As estratégias sugeridas pelo modelo são comparadas às alternativas existentes na lei brasileira de falências e recuperação de empresas (Lei n. $11.101 / 2005)$.

Os conceitos relacionados aos temas tratados são apresentados no capítulo II, onde há também uma visão resumida das teorias econômicas utilizadas, com o objetivo de auxiliar o leitor a compreender os conceitos. Há, ainda, uma breve exposição da teoria dos jogos e da teoria do desenho de mecanismos.

O modelo proposto é estruturado de acordo com a teoria da escolha racional e a teoria dos jogos. Analisam-se os principais interesses envolvidos, limitados às restrições existentes, que reduzem as escolhas dos agentes (capítulo III).

Estudam-se também os comportamentos de devedor e credores, resumidos a três possibilidades: estabelecimento de negociações privadas, falência e recuperação da empresa. Compreendem-se as decisões mais prováveis e também os possíveis erros na tomada de decisão, influenciados pelos interesses dos agentes, restrições econômicas e imposições legais.

Apontam-se os problemas de revelação de informações, as decisões tomadas em assembléia de credores, os efeitos das decisões e propõem-se soluções para os principais problemas, sempre com base nos conceitos da teoria dos jogos e na teoria do desenho de mecanismos (capítulo IV).

A formulação matemática do modelo proposto é apresentada no capítulo V. 


\section{Abstract.}

This dissertation uses a methodology of law and economics to present a gametheoretic model, designed with the purpose of analyzing the strategies, selected by debtors and creditors, to make decisions between liquidation and reorganization of a distressed firm. The strategies recommended by the model are compared with the existing alternatives in the Brazilian Bankruptcy Law (law n. 11.101/2005).

The concepts related to the subject are presented in chapter II, where there is an overview of the economic theories, to simplify the understanding of the concepts. There is also an overview of game theory and mechanism design theory.

The proposed model is structured according to the rational choice theory and game theory. It analyzes the main interests involved, and the existing constraints that limit the choices made by the agents (chapter III).

It also studies the behavior of debtors and creditors, limited to three possibilities: establishment of private negotiations (workout), liquidation or reorganization of the firm. It analyzes the most probable decisions and also the possible errors in the decision making process, influenced by interests involved, economic and legal constraints.

The dissertation analyses the problem of revelation of information, decisions taken in creditors' assemblies, effects of those decisions, and proposes solution to the main problems, based on concepts of game theory and mechanism design theory (chapter IV).

The model's mathematical formulation is presented in chapter V. 